\title{
Addendum to the RCRA Assessment Report for Single-Shell Tank Waste Management Area S-SX at the Hanford Site
}

V. G. Johnson

C. J. Chou

September 1999

Prepared for

the U.S. Department of Energy

under Contract DE-AC06-76RLO 1830

Pacific Northwest National Laboratory

Richland, Washington 99352 


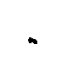




\section{DISCLAIMER}

This report was prepared as an account of work sponsored by an agency of the United States Government. Neither the United States Government nor any agency thereof, nor any of their employees, make any warranty, express or implied, or assumes any legal liability or responsibility for the accuracy, completeness, or usefulness of any information, apparatus, product, or process disclosed, or represents that its use would not infringe privately owned rights. Reference herein to any specific commercial product, process, or service by trade name, trademark, manufacturer, or otherwise does not necessarily constitute or imply its endorsement, recommendation, or favoring by the United States Government or any agency thereof. The views and opinions of authors expressed herein do not necessarily state or reflect those of the United States Government or any agency thereof. 


\section{DISCLAIMER}

Portions of this document may be illegible in electronic image products. Images are produced from the best available original document. 


\section{Contents}

1.0 Introduction.

2.0 Purpose and Scope

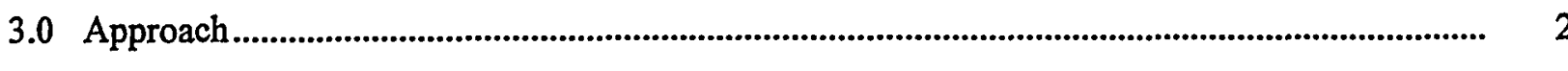

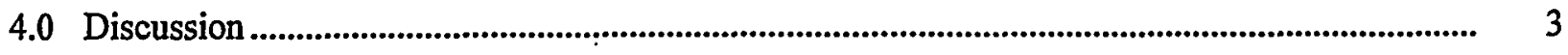

4.1 Vadose Zone Cesium-137 Depth Distribution............................................................. 4

4.2 Significance of Surface Contamination ............................................................................. 5

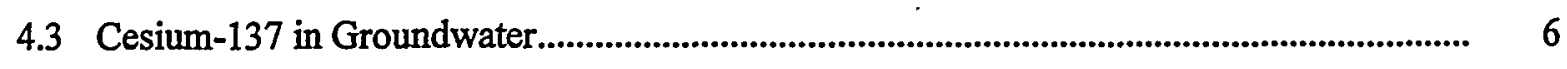

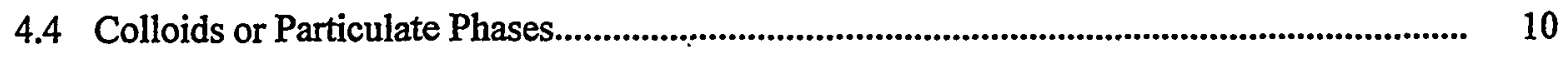

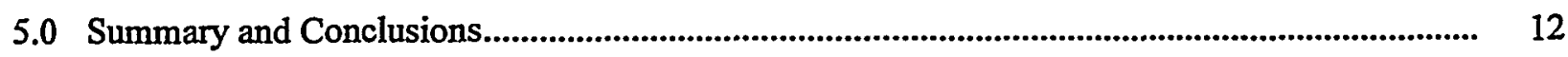

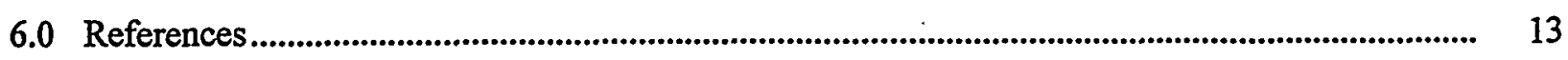

Appendix A - Washington State Department of Ecology Comments on Assessment Report

PNNL-11810

Appendix B - Disposition of Comments

B.1

\section{Figures}

1 Cesium-137 Concentrations Versus Time at Waste Management Area S-SX Wells .

2 Normalized Cesium-137 Concentrations Versus Time at Waste Management Area S-SX Wells

3 A Comparison of the Mean for the Field Trip Blanks with the Corresponding Well Results. 


\subsection{Introduction}

The initial Resource Conservation and Recovery Act (RCRA) groundwater quality assessment report for Waste Management Area S-SX (PNNL-11810) was issued in January 1998. The report stated a plan for conducting continued assessment would be developed after addressing Washington State Department of Ecology (Ecology) comments on initial findings in PNNL-11810. Comments from Ecology were received by U.S. Department of Energy, Richland Operations Office (DOE-RL) on September 24, 1998. Shortly thereafter, Ecology and DOE began dispute resolution and related negotiations about tank farm vadose issues. This led to proposed new Tri-Party Agreement milestones covering a RCRA Facility Investigation-Corrective Measures Study (RFI/CMS) of the four single-shell tank farm waste management areas that were in assessment status (Waste Management Areas B-BX-BY, S-SX, T and TX-TY). The RCRA Facility Investigation includes both subsurface (vadose zone and groundwater) and surface (waste handling facilities and grounds) characterization.

Many of the Ecology comments on PNNL-11810 are more appropriate for, and in many cases are superseded by, the RFI/CMS at Waste Management Area S-SX. The proposed Tri-Party Agreement milestone changes that specify the scope and schedule for the RFI/CMS work plans (Tri-Party Agreement change number M-45-98-0) were issued for public comment in February 1999. The Tri-Party Agreement narrative indicates the ongoing groundwater assessments will be integrated with the RFI/CMS work plans. This addendum documents the disposition of the Ecology comments on PNNL-11810 and identifies which comments were more appropriate for the RFI/CMS work plan.

\subsection{Purpose and Scope}

The primary purpose of this addendum is to document the disposition of groundwater related issues identified by Ecology in their September 1998 letter to DOE. Although many of the comments are related to the RFI/CMS process and deal with facility and vadose zone issues, each of the 146 comments submitted is addressed and the disposition documented in this addendum. Hopefully, this effort will be an avenue for the exchange of ideas, will help to facilitate associated RCRA Facility Investigation discussion, and will lead to resolution and incorporation of Ecology comments and concerns through the RFI/CMS work plan development process. 


\subsection{Approach}

The comments and issues raised by Ecology were first categorized. The comments were sorted into the following general categories:

1. Regulatory. The comments in this category relate to current Washington Administrative Code regulations, applicability of either RCRA-based standards or Atomic Energy Act standards and definitions. There was a tendency to apply current RCRA and Washington Administrative Code standards to older data collected during the period prior to 1989 when only the Atomic Energy Act guidelines applied. This category also includes recommended changes in wording. In addition, there were references made to application of detection monitoring phase activities, for example, statistical comparison of upgradient and downgradient specific conductance. Because the regulated unit is no longer in detection monitoring status, the regulatory language governing assessment activities was followed.

2. Subsurface Physical Model Description. The comments involved interpretation of stratigraphy, evidence for perched water, conceptualization of waste movement in the vadose żone and groundwater, and evidence for widespread movement of cesium-137 through the vadose zone to groundwater. This category seemed to account for the majority of the differences of opinion.

3. Data and Sampling Issues. This category included comments relating to the interpretation of groundwater radionuclide data at or near the detection limit, appropriate standards, treatment of outliers, filtered versus unfiltered results for trend plots, proper use of older data in the Hanford Environmental Information System (HEIS) groundwater database, data entry errors, and pumped or bailed sample collection.

4. Additional Data and Discussion. This category included requests for more information to support tentative conclusions made in the report. Additional data provided as a result of comments in this category included specific conductance, hydrographs, water table dynamics and flow direction, stratigraphic evidence for surface water infiltration, inclusion of surface or near-surface contamination as possible sources of the observed groundwater contamination, and clarification about depth distribution of vadose zone contamination and related groundwater contamination. The breadth and intensity of the Ecology comments, and the information provided in response, strengthen the draft plan (PNNL-12114) as well as the overall evaluation and conclusions based on the existing data.

5. Scope Issues. There was an apparent misunderstanding of either the wording or intent, or both, regarding the purpose of the assessment report (PNNL-11810). Contrary to the implied expectation of the reviewer(s), the initial assessment report was never intended as a RCRA Facility Investigation. The report followed the plan submitted to Ecology in 1996, which limited the study to groundwater observations. However, stratigraphy and some vadose zone transport modeling tasks were included in the 1996 plan even though this may be more appropriate for the vadose zone portion of a RCRA Facility Investigation. Nevertheless, the scope of the assessment plan included no language suggesting a RCRA Facility Investigation effort was involved. The assessment report (PNNL-11810) perhaps went beyond what was intended in the original 1996 assessment plan by attempting to 
correlate cesium-137 occurrences with stratigraphy. Unfortunately, this may have left the impression that a much broader effort was being attempted than what was actually intended or required. Also, reviewer(s) apparently thought the recommendations and last section (Section 6.0) were intended as the only plan for continuing further assessment. However, the first sentence of Section 6.1 states that a new plan would be issued after Ecology concerns were addressed. This addendum, and the plan for continued groundwater assessment (PNNL-12114) fulfill the referenced statement in PNNL-11810, Section 6.1.

6. Monitoring Well Network. Several comments were either directly or indirectly related to concerns about the adequacy of monitoring well spatial coverage. New wells are proposed to correct deficiencies that were also identified in the assessment report. Disagreement exists over use of older wells for upgradient spatial coverage until replacement wells can be drilled. The location and utility of one existing RCRA well also was questioned. Changes in groundwater flow direction as the water table declines confounds this issue.

After developing a sense of the breadth and nature of the comments, the individual numbered comments were addressed one-by-one. The disposition included one or more of the following:

1. incorporation in the draft groundwater plan (PNNL-12114)

2. inclusion of additional data and discussion as provided in this addendum

3. deferral to the RCRA Facility Investigation work plan development process.

The disposition of each numbered comment is documented in Table B.2 with expanded narrative, graphics, and data tables (Appendix B).

While the detailed comment-by-comment disposition ensured that each numbered comment was addressed and the disposition documented, larger issues were evident from thoughtful consideration of the specific comments and questions. The larger issues are better handled using a more open or free form approach. Accordingly, the following discussion addresses the most significant overarching issues. Additional discussion is included in the expanded comment explanations following Table B.2.

\subsection{Discussion}

Several comments leave the impression that the reviewer(s) believe cesium-137 is broadly distributed with depth and over a wide area. Also, they apparently felt that some cesium-137 has migrated through the vadose zone to groundwater beneath Waste Management Area S-SX. The evidence cited for this includes the interpretive 3-dimensional (3-D) visualizations of spectral gamma log results (DOE 1996) for the lowest concentration contour interval $(0.1 \mathrm{pCi} / \mathrm{g})$ and certain groundwater data cited from the HEIS database. Colloidal (or particulate) transport is a related issue arising from interpretation of filtered 
versus unfiltered metal and radionuclide data. Another key issue that has a bearing on interpretation of existing data is the applicability of appropriate standards and regulations with respect to old versus new data. These broader issues are discussed in the following sections.

\subsection{Vadose Zone Cesium-137 Depth Distribution}

Spectral gamma log results for cesium-137 were first presented in 3-D plots in the SX tank farm report (DOE 1996). The graphic displays suggest low-level contamination is deep and widespread. The issue is the significance of gamma logging results at such low levels $(0.1 \mathrm{pCi} / \mathrm{g})$ when drag down, and other sources of global fallout and local contamination, may be as high or higher. The current tank farm reports in the same series are not using the lowest contour intervals $(0.1 \mathrm{pCi} / \mathrm{g})$. MACTEC is now using a more selective approach to plotting spectral gamma results. This change evolved out of both peer review comments and recommendations by the Expert Panel.

Even if there is deeply distributed cesium-137 $(0.1 \mathrm{pCi} / \mathrm{g}$ or lower) in the vadose zone beneath the S-SX tank farms, its significance to human health and the environment is not clear. For example, the soil and sediment background of cesium-137 from atmospheric testing is as high or higher than $0.1 \mathrm{pCi} / \mathrm{g}$. Cesium-137 concentrations on the order of $1 \mathrm{pCi} / \mathrm{g}$ due to global fallout have been found in sediment from the Bull Run watershed (Portland's drinking water source) and up to $7.7 \mathrm{pCi} / \mathrm{g}$ in other mountain lakes in Oregon (Paris 1994). Sediment from Priest Rapids Dam upstream of Hanford contains cesium137 of $\sim 0.5 \mathrm{pCi} / \mathrm{g}$ (PNNL-11139), which is also attributable to global fallout. Also, the risk based cesium-137 cleanup standard established for near-surface soils in the 100 Areas is $10 \mathrm{pCi} / \mathrm{g}$. Thus from a materiality perspective for cleanup or tank farm closure, $0.1 \mathrm{pCi} / \mathrm{g}$ deeply distributed cesium- 137 in the vadose zone beneath the tank farms is an insignificant near-term risk even if such low concentrations do exist. On the other hand, it has been proposed that even small amounts of cesium-137 deeply distributed in the soil could indicate an enhanced mobility pathway involving colloidal size particles with adsorbed cesium-137. In the latter case, the deeply distributed cesium-137 could serve as a tracer for other colloid bound radionuclides such as transuranics. Colloid pathway studies are needed to evaluate this and related enhanced mobility hypotheses using techniques and methods beyond the scope of the typical assessment project.

As indicated above, the question of whether or not such low cesium-137 concentrations may actually exist deep in the vadose zone and whether or not cesium-137 can or has migrated to groundwater through the vadose zone, is an open issue. If detectable cesium-137 does exist in the S-SX monitoring wells, even at very low levels, it could indicate the presence of a colloidal pathway to groundwater. This is a potentially important issue concerning the long-term mobility status of other particle-associated radionuclides with long half-lives (e.g., transuranics) that are too deep in the soil column to be removed or might be driven deeper during sluicing operations. 


\subsection{Significance of Surface Contamination}

Other Ecology comments point to the widely distributed cesium-137, implied by the surface or areal plots in the SX tank farm report by MACTEC (DOE 1996), could be groundwater contamination sources from nearly the entire area of the tank farm. Both the 3-D plots as well as near-surface activity plots show low-level cesium-137 covers the entire area of the tank farm. Much smaller areas with concentrations of 1,000 to $10,000 \mathrm{pCi} / \mathrm{g}$ are indicated for the southcentral to southwest area of the SX tank farm (Figure 17, DOE 1996). If cesium-137 detected from gamma logging represents tank waste originally spilled in this area, the corresponding technetium-99 (or other constituents) can be estimated from contaminant ratios in single-shell tank waste. For example, the cesium-137/technetium- 99 activity ratio for SX tank waste is approximately $10,000: 1$. Thus the highest near-surface cesium-137 zone $(10,000 \mathrm{pCi} / \mathrm{g}$ of cesium-137) originally would have contained about $1 \mathrm{pCi} / \mathrm{g}$ of technetium- 99 . Assuming steady state moisture migration and a weight percent moisture content of $10 \%$ (from neutron moisture logs near tank SX-109), and assuming all the technetium-99 is soluble and that none precipitated in the tanks, the corresponding pore fluid technetium- 99 concentration in a unit mass of soil would be approximately

$$
(1 \mathrm{pCi} / \mathrm{g} \text { - soil }) / 0.10 \mathrm{~g} \text {-water } / \mathrm{g} \text { soil })=10 \mathrm{pCi} / \mathrm{ml} \text { or } 10,000 \mathrm{pCi} / \mathrm{L} \text {. }
$$

This represents the highest concentration in pore fluid that could arrive at the water table from an initial soil column cesium- 137 content of $10,000 \mathrm{pCi} / \mathrm{g}$ soil. The highest concentrations of technetium-99 observed in groundwater are about $8,000 \mathrm{pCi} / \mathrm{L}$. Thus moisture migrating through the vadose zone would have to enter the aquifer undiluted (shallow contaminant layer of $100 \%$ vadose zone pore fluid) and remain undiluted during pumping of the sample from the well to yield technetium-99 concentrations in groundwater near what has been observed. If such a transport process occurred, most of the sampling conducted to date would have either missed the shallow layer at the top of the aquifer, or the contaminant layer would have been greatly diluted due to borehole mixing during sampling. In the latter case, a vadose zone cesium-137 source needs to be much higher than $10,000 \mathrm{pCi} / \mathrm{g}$ to yield the maximum technetium-99 concentrations that have been observed to date in the S-SX monitoring wells.

While the above is only a simplified calculation, it illustrates the point that surface contamination of cesium- 137 greater than $10,000 \mathrm{pCi} / \mathrm{g}$ is needed to account for significant groundwater contamination sources (i.e., sources large enough to account for the maximum technetium-99 concentrations observed to date). Such sources could, however, account for some of the lower concentrations observed in groundwater $(100$ to $1,000 \mathrm{pCi} / \mathrm{L})$.

The order-of-magnitude estimate discussed above illustrates the value of modeling moisture and contaminant movement from the vadose zone into the aquifer. Such refined calculations could help narrow the possible sources or at least eliminate insignificant source areas. 


\subsection{Cesium-137 in Groundwater}

The Ecology comments cite the HEIS database as showing "several" detections of cesium-137 in groundwater at Waste Management Area S-SX. Because the vadose zone boreholes are only 75 to $130 \mathrm{ft}$ deep, the occurrence of cesium-137 in groundwater ( $211 \mathrm{ft}$ below ground surface) would imply cesium137 has migrated beyond the deepest vadose monitoring borehole and reached the water table. The data for the wells cited that show cesium-137 detections are plotted with respect to either concentration versus time (Figure 1) or normalized (Figure 2) to analytical uncertainty (reported value divided by the 2-sigma counting errors). These plots indicate there is only one clear case of detected cesium-137 in groundwater (well 299-W23-7) where cesium-137 remains consistently above zero (positive values). This well has been identified previously for further evaluation (PNNL 11810, Section 6.0).

Figures 1 and 2 indicate most of the cesium-137 results randomly fluctuate around zero (positive and negative values). This is expected when there is either no activity present or it is near the detection limit of the method. Only when there is a sustained or confirmed positive occurrence (successive positive values) is there evidence of a real detection. It is also noteworthy that the field blank results shown together with the well results (Figure 1) cover about the same range as the well results. This suggests that most if not all the reported cesium-137 for the wells (except for 299-W23-7) shown can be accounted for by either background (fallout or fugitive dust) or by the random fluctuation around zero typically observed for blanks.

A comparison of the mean for the field trip blanks (FTR) and the corresponding well results is shown in Figure 3. Results for well 299-W23-7 were excluded from this comparison because it is known that cesium-137 occurs in this well.

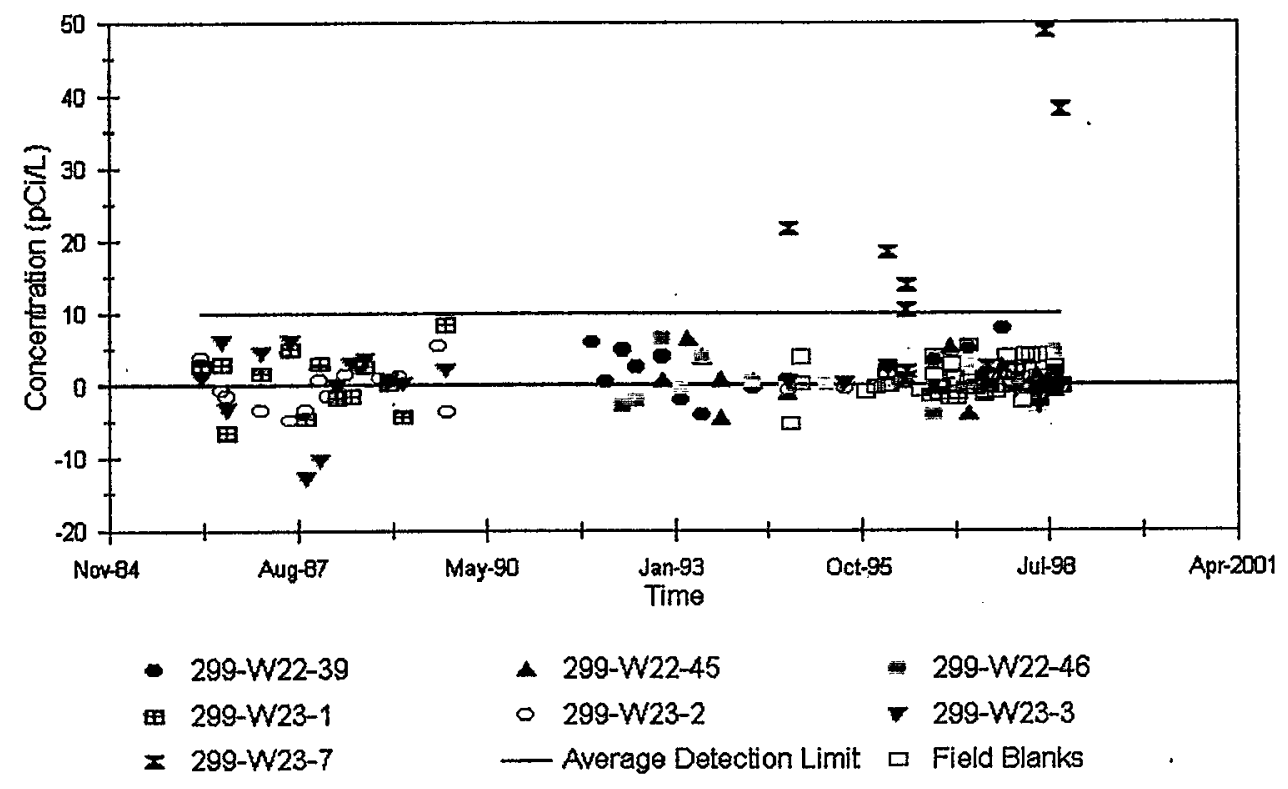

Figure 1. Cesium-137 Concentrations Versus Time at Waste Management Area S-SX Wells 


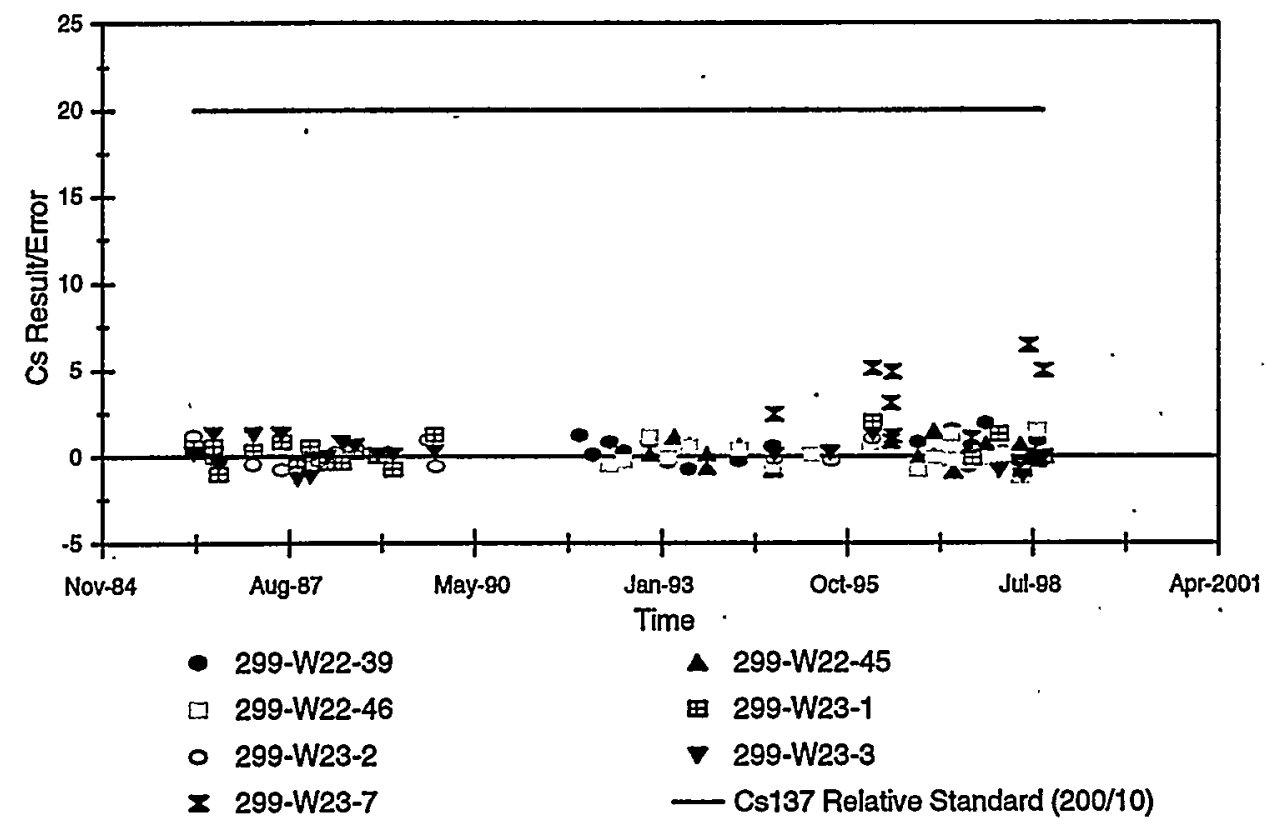

Figure 2. Normalized Cesium-137 Concentrations Versus Time at Waste Management Area S-SX Wells

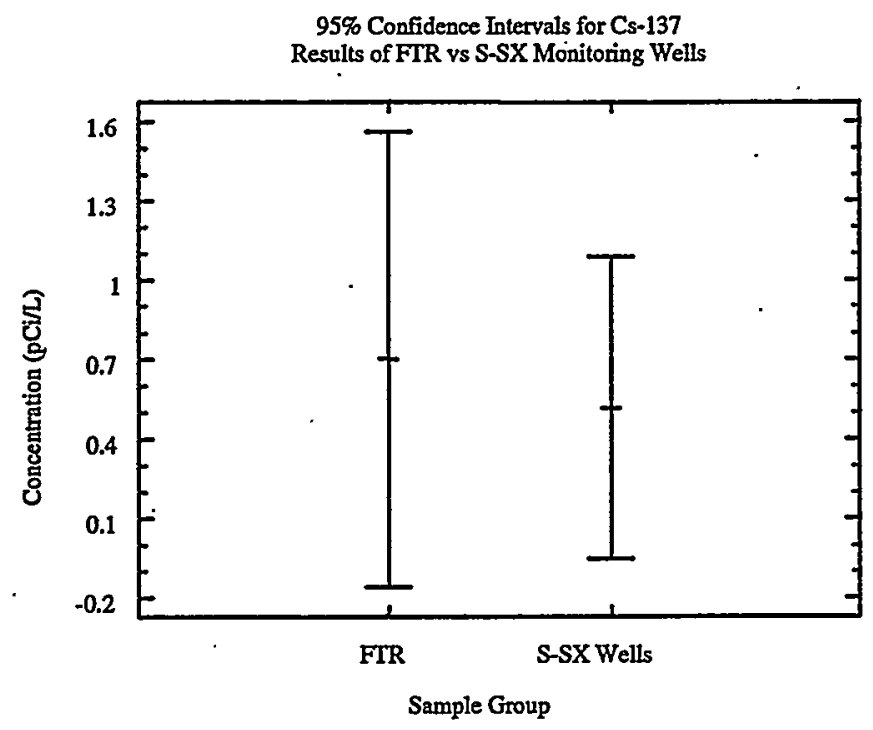

Figure 3. A Comparison of the Mean for the Field Trip Blanks (FTR) with the Corresponding Well Results 
A two-sided $95 \%$ confidence interval for the mean of the field blanks $\left(\mathrm{x}_{\text {blank }}\right)$ is plotted in Figure 3 along with the same for the mean of the S-SX well $\left(\mathrm{x}_{\text {wells }}\right)$ results using the following equations:

$$
\begin{aligned}
& \text { Field Blanks } s_{\text {lower limit }}=\bar{x}_{\text {blank }}-t_{(m+n-2,0.975)} * S_{p} / m^{1 / 2} \\
& \begin{aligned}
& \text { Field Blanks } \\
& \text { upper limit }=\bar{x}_{\text {blank }}+t_{(m+n-2,0.975)} * S_{p} / m^{1 / 2} \\
& \text { S-SX Wells } s_{\text {lower limit }}=\bar{x}_{\text {wells }}-t_{(m+n-2,0.975)} * S_{p} / n^{1 / 2} \\
& \text { S-SX Wells } \\
& \text { upper limit }
\end{aligned}=\bar{x}_{\text {wells }}+t_{(m+n-2,0.975)} * S_{p} / n^{1 / 2}
\end{aligned}
$$

where $m$ is the number of field blank observations $(m=48) ; n$ is the number of observations from S-SX wells $(n=109)$; $t_{(m+n-2,0.975)}$ is the 0.975 percentile from the $t$ distribution with $(m+n-2)$ degrees of freedom $\left[t_{(155,0.975)}=1.976\right]$; and $S_{p}{ }^{2}$ is the pooled variance, which is given by

$$
\mathrm{S}_{\mathrm{p}}^{2}=\left[(\mathrm{m}-1)^{*} \mathrm{~S}_{\text {blanks }}{ }^{2}+(\mathrm{n}-1) * \mathrm{~S}_{\text {wells }}{ }^{2}\right] /(\mathrm{m}+\mathrm{n}-2)
$$

$\mathrm{S}_{\text {blanks }}{ }^{2}$ and $\mathrm{S}_{\text {wells }}{ }^{2}$ are sample variance computed from the blanks and wells, respectively, and $\mathrm{S}_{\mathrm{p}}$ is the square root of $\mathrm{S}_{\mathrm{p}}{ }^{2}$.

Figure 3 shows there is no difference in the means between the field blanks and the S-SX wells because the two confidence intervals overlap. The error bars (standard error of the mean or SEM) are smaller for the well group ( 109 observations) than for the blank group ( 48 observations) because, as indicated in the equations above, the standard deviation is divided by the square root of the number of observations to obtain the SEM. The mean concentrations for the two groups $(0.7 \mathrm{pCi} / \mathrm{L}$ and $0.5 \mathrm{pCi} / \mathrm{L}$ for blanks and wells, respectively) suggest there may be some cesium-137 present. However, Figure 3 also indicates that if cesium-137 is present in the samples collected from the monitoring wells, the mean value is at or below the mean of the field blank results. Thus, except for well 299-W23-7, it cannot be concluded that cesium-137, attributable to the waste management area, occurs in groundwater from these wells.

The detection limits for cesium-137 for the data shown in Figures 1 and 2 were about $10 \mathrm{pCi} / \mathrm{L}$ or $1 / 20$ th of the drinking water standard ( $4 \mathrm{mrem} / \mathrm{yr}$ equivalent concentration). Lower detection limits would be needed to quantify any cesium-137 that might be present. The current detection limit of about $10 \mathrm{pCi} / \mathrm{L}$ for routine measurements was considered adequate for all existing Waste Management Area S-SX RCRA groundwater monitoring data because the minimum detection level is about $1 / 20$ th of the drinking water standard. Using a lower detection limit than the current one would not be meaningful unless the apparent background or blank level (Figure 3) is eliminated.

It is noteworthy also that the positive detections of cesium-137 (well 299-W23-7) appear to be particulate in nature (retained on a 0.4-micron filter). It is not likely that particles larger than 0.4 micron would move through the aquifer or through the vadose zone (mobile colloidal phases are typically much smaller than this). Early gross gamma logs (circa 1970) suggest there was subsurface contamination near the top 
of this well (see Appendix B, Figure B.12). Thus it is possible that contaminated soil fell into the well during installation and/or during rehabilitation (grouting). Follow-up testing has been proposed (PNNL11810, Section 6.0 and PNNL-12114, Section 5.3.3) if the well is capable of producing water. However, water can no longer be pumped from the well.

Counting Error and the HEIS Database. Generally, a ' $U$ ' flag is used in the HEIS database if a reported value for a radionuclide measurement result is less than the 2-sigma counting error (i.e., where the ratio of a result divided by its 2 -sigma counting error is $<1$; see Figure 2 ). This threshold corresponds to approximately a $95 \%$ confidence and could be exceeded by random chance alone about $5 \%$ of the time (false positive rate) even if there is no activity present. A result greater than the 2-sigma counting error would not be flagged in the HEIS database and would thus be interpreted as a "detect." However, as previously indicated, for an apparent detection to be significant, successive measurements need to be positive and above the field blank values. A random mix of negative and positive values over time indicates zero or near-zero activity. Except for well 299-W23-7, the results shown in Figures 1 and 2 appear to randomly fluctuate and are comparable to the field blank results. As noted, if there is cesium-137. present in the groundwater, it would require pre-concentration to quantify.

In response to DOE-HQ Environmental Management Science Program call for proposals, studies may include large volume sampling (pre-concentration) to identify colloidal phases of transuranics and cesium-137. Such studies were identified in the draft plan (PNNL-12114) for continued groundwater quality assessment. Offsite, low-level sample handling and counting labs with rigid contamination control procedures are needed for these low activity measurements.

Old Data. Another HEIS database issue relates to old data that does not have an indication of counting error or detection limit. Ecology stated the discussion should not be limited to RCRA wells or to current observations. For example, the earliest cesium-137 data (beginning in 1959) retrieved from HEIS is for well 299-W23-4 (an old well upgradient from the S-SX farms). Initial cesium-137 results for 1959 through 1961 were all posted as $500 \mathrm{pCi} / \mathrm{L}$ with no other flag or indication about counting error or detection limit. Because there are several consecutive values of exactly $500 \mathrm{pCi} / \mathrm{L}$, this concentration is the implied detection limit at that time. It was common practice to report results as less than the detection limit. The less than symbol $(<)$ was probably dropped when the data was digitized for the Hanford Site database. Thus it cannot be concluded that cesium- 137 occurred at $500 \mathrm{pCi} / \mathrm{L}$, only that the result was $\leq 500 \mathrm{pCi} / \mathrm{L}$. Without the counting error it is not possible to determine if old results in the HEIS database are near the detection limit or not. Therefore, in order to address the Ecology comments regarding cesium-137 in groundwater, only HEIS data that included the associated counting error were used. Additionally, some data that should have been flagged with a ' $U$ ' were not, which may have misled the reviewers. However, in all cases, the individual counting error and subsequent results should be used to evaluate the likelihood that a reported value is truly detected. 


\subsection{Colloids or Particulate Phases (Filtered Versus Unfiltered Water Samples)}

There were a number of comments devoted to metal results based on either filtered or unfiltered samples. This subject has been discussed several times over the years at Hanford and elsewhere. There are two fundamental considerations depending on whether it is an artificial radionuclide or a metal that also occurs in nature or occurs in well casing.

Radionuclides. The current philosophy behind groundwater radionuclide measurements at Hanford is that unfiltered samples should be used for routine measurements. If an anomaly is found, then follow-up investigation may include both filtered and unfiltered sampling with or without added acid. Nitric acid is routinely added immediately in the field to preserve the sample or to prevent certain constituents from precipitating or plating out on the container surfaces during storage prior to analysis. The acidification generally lowers the $\mathrm{pH}$ to 1.5-2. The concentration of hydrogen ions is sufficient to leach some constituents from any particulates present. Thus the result is considered to represent the total (solute plus particulate fraction) in a water sample removed from the well. Because it is the artificial radionuclides that are of interest, the total soluble plus particulate based on acidified, unfiltered sample media represents whatever was found in the well. While this approach may work for artificial radionuclides, problems occur for some metals.

Metals. Both filtered and unfiltered samples were collected routinely for metal analysis until about 1994. The need to reduce analytical costs and other considerations discussed below led to the decision to stop sampling the unfiltered metals group. One problem was that spurious and elevated chromium results frequently were encountered that did not occur in the filtered samples. Because hexavalent chromium (CrVI) is anionic, it should easily pass through a membrane filter. Thus collecting only filtered samples eliminated the false positive problem (exclusion of particulate chromium or $\mathrm{Cr}$ III). The analytical method used, inductively coupled plasma (ICP) detects total metal regardless of its chemical form. The actual chemical species of interest is hexavalent chromium (the toxic form of chromium).

The ambiguity due to the use of the ICP method and filtered samples can be solved by using an analytical method that is specific for hexavalent chromium and by using unfiltered and unacidified samples. This would require analyzing the samples in the field or shortly after returning to the laboratory. This is a data quality objective that needs to be explored in the RCRA Facility Investigation because chromium is a primary contaminant of concern in the single-shell tank waste and, therefore, the most appropriate method of analysis and detection limit should be identified.

Other metal related problems or issues raised involved aluminum. Aluminum is a constituent of concern because of its abundance in tank waste and possible presence in groundwater if it is mobilized as a colloidal phase. However, there is a sample pretreatment problem associated with this measurement. Because the unfiltered samples are acidified, any aluminosilicate minerals that may be occasionally present are partially dissolved. Abnormally high aluminum results are reported in these cases and are associated with high turbidity. As an example, an unfiltered aluminum result of $13,000 \mu \mathrm{g} / \mathrm{L}$ was reported for well 299-W22-44 on March 18, 1994 (see Appendix B, comment 102, data tables). The corresponding filtered aluminum result was $<32.5 \mu \mathrm{g} / \mathrm{L}$. A turbidity of $360 \mathrm{NTU}$ was reported for the 
sampling event. One NTU is approximately $1 \mathrm{mg} / \mathrm{L}$ of particulate. Assuming that all the turbidity was due to an aluminosilicate mineral (clay minerals from either the bentonite seal or indigenous clay from the formation) and that an average aluminum content (as $\mathrm{Al}$ ) for clay minerals of $8 \%$ (an equal mix of Wyoming bentonite and basalt derived clay minerals), the apparent total aluminum present should have been:

$$
0.08 * 360 \mathrm{mg} / \mathrm{L} \text { (particulates) } \cong 29 \mathrm{mg} / \mathrm{L} \text { or } 29,000 \mu \mathrm{g} / \mathrm{L} \text { (as } \mathrm{Al} \text { ). }
$$

Considering that not all the hypothetical mineral phase present may have dissolved, there is reasonable agreement between the predicted and observed aluminum. This comparison demonstrates that dissolution of a natural aluminosilicate mineral (high turbidity) is a reasonable explanation of the highunfiltered aluminum results in the HEIS database. It also demonstrates that care must be taken in how data is retrieved and interpreted from HEIS. For example, the turbidity result for a sampling event should be checked when a high-unfiltered metal result is encountered.

The question of filtered and unfiltered aluminum is another data quality objective issue that may need to be addressed in the context of the overall RCRA Facility Investigation (i.e., what are the constituents of concern and what is the appropriate chemical species to analyze). An appropriate analytical method and sample pretreatment can be developed when the data quality objective process clearly specifies the appropriate standard and the decision to be made with the results. Based on the existing data for filtered and unfiltered samples that have been acidified, all that can be said is that occasional outliers (high aluminum concentrations for acidified unfiltered samples) are coincident with high turbidity.

Considering the slightly alkaline $\mathrm{pH}$ of the groundwater and the chemistry of aluminum at groundwater $\mathrm{pH}(\sim 8)$, very little aluminum is expected to be in solution. Analysis of unacidified and unfiltered samples would be needed for more meaningful unfiltered aluminum results. However, even direct analysis of unfiltered and unacidified water samples by direct aspiration of the sample for the ICP-group metal analysis could yield a total aluminum (particulates plus dissolved). This could arise if the sample were shaken vigorously just prior to analysis. Allowing the particulates to settle to the bottom could be done but this is analogous to filtering the sample.

The possible role of colloidal aluminum (hydrous oxides) and or aluminosilicate phases as potential "carriers" of non-mobile contaminants is of interest for proposed colloid studies as requested in DOE-HQ call for proposals under the Environmental Management Science Program. Results of these efforts may clarify the physical-chemical state of aluminum in groundwater beneath Waste Management Area S-SX. These studies hopefully will lead to a better understanding of colloidal phases in Hanford groundwater and to more meaningful methods of analysis for aluminum and other metals and radionuclides that can occur as both solutes and/or associated with colloidal or solid phases. 


\subsection{Summary and Conclusions}

Based on the foregoing discussion and supplemental information contained in Appendix B, the outcome of the disposition process is summarized as follows.

- The Ecology comments on the initial findings of the RCRA groundwater quality assessment (PNNL-11810) were addressed by

- inclusion of suggested wording in the draft plan for continued assessment (PNNL-12114)

- addition of more data and related discussion (this addendum)

- deferral to the RFI/CMS work plan for Waste Management Area S-SX.

- The breadth and intensity of the Ecology comments, and the resulting responses provided to address the comments, greatly strengthen the continued assessment plan and expand our understanding about subsurface conditions at Waste Management Area S-SX.

- A large number of apparent differences of opinion are attributed to interpretation and use of HEIS data. For example, the HEIS database includes historical as well as recent data. Historical data (since 1957) was collected under different conditions, detection limits, reporting units (e.g., nitrate as $\mathrm{NO}_{3}-\mathrm{N}$ or as $\mathrm{N}$ ) and standards. In many cases, there is no pedigree available for the older data (no counting errors for radionuclide, analytical methods, or flags). The counting error as well as the reported value for radionuclide entries in the database must be used to avoid misleading conclusions.

- The above combined with the different regulatory controls between 1954 (Atomic Energy Act) and 1989 (implementation of RCRA at Hanford), also accounted for some misunderstandings when current standards are used to evaluate old data.

- Other database problems were related to the occurrence of high metal (aluminum and chromium) concentrations for unfiltered water samples. Most if not all of these anomalies can be attributed to high turbidities that periodically occur. Thus both unfiltered metal results must be evaluated along with the corresponding turbidity.

- We propose that performing species specific measurements (e.g., hexavalent chromium on unfiltered and unacidified samples) can eliminate some of the ambiguity in the filtered and unfiltered sample data in the future.

A major difference of opinion exists concerning the significance of very low cesium-137 concentrations in groundwater. We believe that the existing groundwater data from both RCRA and non-RCRA wells in the immediate vicinity of the waste management area (i.e., not influenced by cribs) cannot be used to indicate that widespread migration of cesium-137 through the soil column to groundwater has occurred. It remains to be seen if there is quantifiable cesium-137 in groundwater below the current routine detection limit of $\sim 10 \mathrm{pCi} / \mathrm{L}$ or $1 / 20$ th of the drinking water standard. However, in our opinion, 
the use of much lower limits of detection goes beyond the intended objectives of a groundwater quality assessment and RCRA Facility Investigation. Such studies are more appropriate for enhanced mobility research involving colloids and/or organic complexes.

\subsection{References}

Atomic Energy Act of 1954, as amended, 68 Stat. 919, 42 USC 2011 et seq.

DOE. 1996. Vadose Zone Characterization Project at the Hanford Tank Farms: SX Tank Farm Report. DOE/ID/12584-268, prepared by the U.S. Department of Energy, Albuquerque Operations Office, Grand Junction Projects Office for Richland Operations Office, Richland, Washington.

Paris, R. D. 1994. Environmental Radiological Surveillance Report on Oregon Surface Waters, 1962 1993. Oregon Health Division, Radiation Protection Services, Portland, Oregon.

PNNL-11139. 1996. Hanford Site Environmental Report for Calendar Year 1995. R. L. Dirkes and R. W. Hanf (eds.), Pacific Northwest National Laboratory, Richland, Washington.

PNNL-11810. 1998. Results of Phase I Groundwater Quality Assessment for Single-Shell Tank Waste Management Areas S-SX at the Hanford Site. V. G. Johnson and C. J. Chou, Pacific Northwest National Laboratory, Richland, Washington.

PNNL-12114. 1999. RCRA Assessment Plan for Single-Shell Tank Waste Management Area S-SX at the Hanford Site. V. G. Johnson and C. J. Chou, Pacific Northwest National Laboratory, Richland, Washington.

RCRA - Resource Conservation and Recovery Act. 1976. Public Law 94-580, as amended, 90 Stat. 2795,42 USC 6901 et seq.

Tri-Party Agreement. 1996. Washington State Department of Ecology, U.S. Environmental Protection Agency, and U.S. Department of Energy. Hanford Federal Facility Agreement and Consent Order. Document No. 89-110, Rev. 4, Ecology, Olympia, Washington. 


\section{Appendix A}

\section{Washington State Department of Ecology Comments on Assessment Report PNNL-11810}




\section{3}

STATE OF WASHINGTON

\section{DEPARTMENT OF ECOLOGY}

1315 W. 4th Avenue - Kennewick, Washington 99336.6018 - (509) 735-7581

September 16, 1998

Mr. Marvin J. Furman

RECEIVED

U.S. Department of Energy

P.O. Box 550, MSN: HO-12

SEP 241998

Richland, WA 99352

DOERL/DIS

Dear Mr. Furman;

Re: Comments on "Results of Phase I Groundwater Quality Assessment for Single-Shell Tank Waste Management Areas S.SX at the Hanford Site" January 1998 (PNNL11810)

The Washington State Department of Ecology (Ecology) has initiated its review of the above document. The number of comments generated thus far has prompted Ecology to provide you with the enclosed list of completed comments. Ecology believes this transmittal will give the U.S. Department of Energy (USDOE) and its contractors sufficient direction to begin revising the document. As can be observed from the enclosed comments, substantial editing of this document is necessary. Additional comments may be forthcoming as Ecology completes its review.

Ecology will also provide comments on the remaining Single-Shell Tank Groundwater Quality Assessments that USDOE has transmitted to Ecology. Ecology expects, however, that many of the issues identified in the enclosed comments will also be applicable to this other document.

If you have any questions, please coniact Alex Stone (Storage) at (509) 736-3018 or Suzanne Dahl (Disposal) at (509) 736-5705.

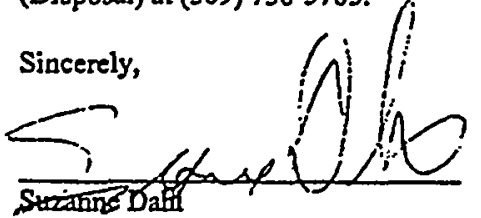

TWRS Disposal Project Manager Nuclear Waste Program

SD:AS:sb

Enclosure

cc: Maureen Hunemuller, USDOE Bob Lober, USDOE Mike Thompson, USDOE Doug Sherwood, EPA Janice Williams, FDH Dave Myers, LMAC Jim Bertsch, MACTEC-ERS

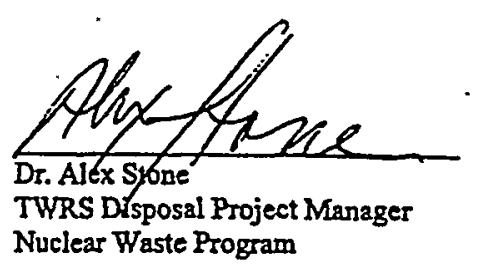

Stuart Harris, CTUIR

Stan Sobczyk, NPT

Wade Riggsbee, YTN

Merilyn Reeves, HAB

Mary Lou Blazek, OOE

Administrative Record: SST TSD S-2-4 and Vadose Zone Characterization 
"Results of Phase I Groundwater Quality Assessment for Single-Shell Tank Waste Management Areas S-SX at the Hanford Site" January 1998 (PNNL-11810) Ecology Review Comments (July - August 1998)

1. Page iii. Why reference FFCA? Does it set standards for RCRA phase i? Please reference appropriate CFR and WAC.

2. Page iii, Summary, $1^{\text {th }}$ paragraph. The term "Phase $\Gamma$ " has no regulatory basis. Delete the term and insert the applicable regulatory citation. Recommended wording is: "Pacific Northwest National Laboratory conducted a "first determination" groundwater quality assessment for the U.S. Department of Energy, Richland Operations Office, in accordance with 40 CFR 265.93(d)(4) by reference of WAC 173-303-400(3)."

3. Page iii, Summary, $1^{\text {st }}$ paragraph. It is recommended that an additional sentence be added to the first paragraph that reflects the regulatory status of the - groundwater-monitoring program. Recommended wording is: "This report documents the first determination evaluation of 40 CFR 265.93(d)(4) and describes the assessment monitoring program of 40 CFR 265.93(7)(i)."

4. Page iii, Summary, $2^{\text {nd }}$ paragraph. As Washington Administrative Code (WAC) 173-303-040 defines "ancillary equipment", insert the words "equipment and" between the words "ancillary" and "waste systems" in the first sentence.

5. Page iii, Summary, $2^{\text {nd }}$ paragraph. The second sentence identifies the date the unit was "placed in the assessment groundwater monitoring program" as August 1996. A review of the downgradient groundwater data from RCRA and non-RCRA wells indicates groundwater contamination occurring as early as 1986. Therefore, it is recommended that the summary not identify that the assessment monitoring program was not initiated until August 1996. It is recommended the second sentence read "The unit is regulated under RCRA interim-status regulations (40 CFR, Subparts J and F, by reference of WAC 173-303-400(3)) and was placed in assessment groundwater monitoring (40 CFR 265.93(d)(4)) after elevated waste constituent and indicator parameter measurements/observations (i.e., specific conductivity, chromium, technetium-99, etc.) in S-SX WMA downgradient monitoring wells were repeatedly observed and confirmed."

6. Page iii, Summary, $2^{\text {nd }}$ paragraph. The term "Phase l" has no regulatory basis. Delete the term in the last sentence of the paragraph and insert the applicable regulatory citation. Recommended wording is: "The first determination, allowed under 40 CFR 265.93(d), provides the owner-operator of a facility with an opportunity to demonstrate that the regulated unit is not the source of groundwater contamination." 
7. Page iii, Summary, $3^{\text {td }}$ paragraph, $1^{\text {st }}$ bullet. As the radionuelides represent constituents of the waste and "RCRA" is synonymous with "dangerous waste", recommended wording for the first sentence is: "Distribution patterns for waste constituents indicate the WMA S-SX has contributed to and/or been the source of groundwater contamination observed in downgradient monitoring wells."

8. Page iii, Summary, $3^{\text {rd }}$ paragraph, $1^{\text {st }}$ bullet. As the groundwater and vadose zone data is sufficient to make the first determination, recommended wording for the second sentence is: "It is concluded that multiple source locations in the WMA exist to explain the observed spatial and temporal groundwater contamination patterns."

9. Page iii, 2nd bullet: There is no "interim" drinking water standard in the regulation. Remove the word "interim".

10. Page iii, Summary, $3^{\text {rd }}$ paragraph, $2^{\text {nd }}$ and $3^{\text {rd }}$ bullets. Due to the volume of data and the spatial and temporal groundwater contamination patterns observed thus far, the second and third bullets should be re-written to discuss just one constituent per bullet. In addition, due to the direction of groundwater flow and the location of the "RCRA" downgradient monitoring wells, the observations should not be limited to "RCRA" wells. The discussion should also not be limited to "current" observations. Many data exist which add value to the summary discussion. Some recommended wording is: "Drinking water standards for technetium-99 have been and currently are exceeded in S-SX WMA downgradient monitoring wells. Technetium-99 concentrations at well 299-W2246, located at the southeastem comer of the SX tank farm, have been observed (from November 1996 to February 1998) to exceed the U.S. Environmental Protection Agency (EPA) interim drinking water standard (DWS) of $900 \mathrm{pCi} / \mathrm{L}$ up to a factor of five times. Technetium-99 concentrations at a non-RCRA well 299W23-1 (located inside the S tank farm) have also been observed (from June 1986 to May 1998) to exceed the DWS up to a factor of nine times. Similarly, technetium-99 concentrations at another non-RCRA well 299-W23-7 (located northeast of the SX tank farm) have also been observed (from September 1987 to January 1991) to exceed the DWS up to a factor of eight times. Similarly, technetium-99 concentrations at another non-RCRA well 299-W23-2 (located inside the SX tank farm) have also been observed (from December 1987 to September 1994) to exceed the DWS up to a factor of 6 times. Technetium-99 concentrations at another RCRA well $299-$ W22-45 have recently been observed to be significantly increasing from previously measured concentrations (November 1992 to August.1996) to more than one-half the DWS (427 pCi/L on May 12, 1998)."

11. Page iii, Summary, $3^{\text {to }}$ paragraph, $2^{\text {Dd }}$ and $3^{\text {rd }}$ bullets. Due to the volume of data and the spatial and temporal groundwater contamination patterns observed thus far, the second and third bullets should be re-written to discuss just one 


\section{3}

constituent per bullet. In addition, due to the direction of groundwater flow and the location of the "RCRA" downgradient monitoring wells, the observations should not be limited to "RCRA" wells. The discussion should also not be limited to "current" observations. Many data exist which add value to the summary discussion. Some recommended wording is: "Drinking water standards of $10 \mathrm{mg} / \mathrm{L}$ for nitrate have been and currently are exceeded in S-SX WMA downgradient monitoring wells. Observations of nitrate concentrations at RCRA well 299-W22-46 have exceeded the DWS from 1992 to 1997 (data beyond November 1997 are currently unavailable) with what may appear to be a peak measurement in May 1997. Similarly, the DWS for nitrate has also been exceeded at RCRA downgradient well 299-W22-45 from 1995 to 1997. At this well, the nitrate measurements have consistently increased from February 1996 to November 1997. Similarly, the DWS for nitrate has also been exceeded at RCRA downgradient well 299-W22-39 from 1991 to 1996. At this well, little variation of nitrate concentration has been observed. The DWS for nitrate has also been exceeded at non-RCRA downgradient well 299-W23-2 (located within SX tank farm) from 1987 to 1996 (data beyond March 1996 unavailable) with a peak measurement in September 1994. Similarly, the DWS for nitrate bas also been inconsistently exceeded at non-RCRA downgradient well 299-W23-3 (located at southeastem comer of and within SX tank farm) from 1957 to 1995 with a peak measurement in November 1961."

12. Page iii, Summary, $3^{\text {rd }}$ paragraph, $2^{\text {nd }}$ and $3^{\text {rd }}$ bullets. Due to the volume of data and the spatial and temporal groundwater contamination patterns observed thus far, the second and third bullets should be re-written to discuss just one constituent per bullet. In addition, due to the direction of groundwater flow and the location of the "RCRA" downgradient monitoring wells, the observations should not be limited to "RCRA" wells: The discussion should also not be limited to "current" observations. Many data exist which add value to the summary to discuss. Some recommended wording is: "Drinking water standards of $05 \mathrm{mg} / \mathrm{L}$ for chromium have been exceeded in the RCRA downgradient wells 299-W22-39, 299-W22-44, and 299-W22-46 and in the non-RCRA downgradient well 299. W23-7. Due to the filtration of samples and in particular, the filtration of the most recent samples (typically from March 1994 to February 1998) a trend analysis cannot be performed."

13. Page iii, Summary, $3^{\text {rd }}$ paragraph, $4^{\text {th }}$ and $5^{\text {th }}$ bullets. Due to the volume of data and the spatial and temporal groundwater contamination pattems observed thus far, the fourth and fifth bullets should be re-written to discuss all data available. In addition, due to the direction of groundwater flow and the location of the "RCRA" downgradient monitoring wells, the observations should not be limited to "RCRA" wells. Much data exists which add value to the summary discussion. Some recommended wording is: "Drinking water standards of $200 \mathrm{pCi} / \mathrm{L}$ for cesium- 137 and $8 \mathrm{pCi} / \mathrm{L}$ for strontium-90 have not been exceeded in the RCRA or non-RCRA downgradient wells. Although concentrations of cesium-137 were 
measured in well 299-W22-39 from November 1991 to July 1992, in well 299W22-44 in October 1994, in well 299-W22-45 in April 1993, they have been low ranging from .52 to $6.5 \mathrm{pCi} / \mathrm{L}$. The cesium-137 concentrations measured in nonRCRA well 299-W23-7 (located inside and between the $S$ and SX tank farms) from September 1994 to June 1996 are an exception and ranged from relatively low values of $1.97 \mathrm{pCi} / \mathrm{L}$ to a high of $21.8 \mathrm{pCi} / \mathrm{L}$. Similarly, strontium-90 concentrations have not been detected in any well with the exception of nonRCRA well 299-W23-7 from March 1996 to June 1996. In this well, strontium90 concentrations have ranged from .869 to $6.153 \mathrm{pCi} / \mathrm{L}$. With the exception of well 299-W23-7, these observations are consistent with the expected low mobility of these constituents under Hanford Site conditions. Additional investigation is needed to determine the extent of Cs-137 and Sr-90 contamination related to well 299-W23-7 observations."

14. Page iv, Paragraph 3 from preceding page, $3^{\text {rd }}$ bullet. The term "Phase In" has no" regulatory meaning. Recommended wording for the sentence is: "Further determinations required by 40 CFR 265.93(d)(7)(i) (by reference of WAC 173303-400(3)] will be made and are described in Chapter 6 of this report."

15. Page iv, last bullet: Phase II investigation should include nature and extent and sources of contamination within groundwater and yadose zone.

16. Page 1.1, Section 1.0, $1^{\text {st }}$ paragraph. The term "Phase 1 " in the first sentence has no regulatory meaning. Also, the report should cite the applicability of the Washington Administrative Code. Recommended wording is: "This report presents the findings and conclusions of the first determination, Resource Conservation and Recovery Act of 1976 (RCRA) groundwater quality assessment of Single Shell Tank Waste Management Area (WMA) S-SX as required by 40 CFR 265.93(d) (by reference of WAC 173-303-400(3))."

17. Page 1.1, Section 1.0, $1^{\text {st }}$ paragraph. Due to the considerable volume of data and information which may precede PNNL's efforts which occurred from August 1996 to July 1997, it is appropriate to also identify the data considered during the assessment includes all useable data from all wells. In other words, certain (nonRCRA) wells were installed much earlier than the stated assessment period and meaningful information can be obtained from the consideration of the data collected prior to August 1996. Therefore, the period should at least be inclusive of the time when contamination was first detected in a downgradient monitoring well. For example, from well 299-W23-7, significantly elevated gross beta was measured in June 1987 and grossly elevated technetium-99 was measured in September 1987. Similarly, from well 299-W23-1, elevated gross beta was measured in March 1959 and grossly elevated technetium-99 was measured in . June 1986. It should be noted that technetiurn-99 for well 299-W23-1 was first measured on June 23, 1986. Related to the most recent data used, as Ecology has taken more than six months to review this document, it is requested the data 
period be extended to December 1998 . Therefore, recommended wording for the second sentence is: "Pacific Northwest National Laboratory conducted the assessment from August 1996 to July 1997 using data collected between the early 1970's and December 1998.

18. Page 1.1 , Section $1.0,1^{\text {st }}$ paragraph, $2^{\text {sd }}$ bullet. For consistency with WAC 173303-040, insert the words "equipment and" between "ancillary" and "waste systems".

19. Page 1.1, Section 1.1. Please note that these active TSD units are not in compliance with RCRA and appropriate WAC Code, but are allowed active status under the Hanford Federal Facility Agreement and Consent Order (Tri-Party Agreement).

20. Page 1.1, Section 1.1. Nature of extent contamination determination is not just within groundwater, but also the vadose zone.

21. Page 1.1, Section 1.1, $1^{\text {th }}$ paragraph. Include the applicable regulatory cite for management of the tanks. Recommended wording is: "The tanks and ancillary equipment in WMA S-SX are RCRA treatment and storage units managed in accordance with Title 40, Code of Federal Regulation (CFR) Part 265, Subparts F and J (40 CFR 265.92 and 265.196 [by reference of Washington Administrate Code (WAC) 173-303-400(3)]. In addition, the units will be closed in accordance with WAC 173-303-610."

22. Page 1.1, Section $1.1,2^{\text {nd }}$ paragraph. The term "detection monitoring program" is typically used in reference to final facility status monitoring program for which no contamination from the regulated unit has been detected. Change "A detectionlevel groundwater monitoring program" to "An indicator parameter monitoring program".

23. Page 1.1, Section 1.1, $2^{\text {nd }}$ paragraph. As groundwater monitoring occurred for WMA S-SX long before 1990, insert the word "administratively" between "was" and "initiated" in the first sentence. .

24. Page 1.1, Section 1.1, $2^{\text {nd }}$ paragraph. As the assessment-monitoring program could have been initiated much earlier than 1996 , insert the word

"administratively" between "was" and "placed" in the second sentence. Also, identify which WMA tank system unit Ecology's 1996 directive was addressing.

25. Page 1.1, Section $1.1,3^{\text {rd }}$ paragraph. There is no regulatory basis for the term "Phase I". In addition, the first sentence is describing how the regulations are typically applied. For reasons, periaps not beneficial to describe, the WMA S-SX unit's initiation of assessment monitoring was incorrectly delayed. Similarly, the unit's first determination may be considered to have been performed over an 
extended duration. Recommended wording for the first sentence is: "The first determination, and the subject of this report, is typically a short-term sampling program intended to provide the ownez/operator an opportunity to substantiate a false positive claim."

26. Page 1.1, Section 1.1, $3^{\text {td }}$ paragraph. Re-write the second sentence as: "If the owner/operator detemines, based on the results of the first determination, that no dangerous waste and/or dangerous waste constituents from the unit have entered the groundwater, then he may reinstate the indicator parameter monitoring program (40 CFR 265.93(d)(6)).

27. Page 1.1, Section 1.1, $3^{\text {td }}$ paragraph. Re-write the third sentence as: "If, however, contamination is confirmed (i.e., the regulated unit is the source of groundwater contamination), then further determinations are required under $40 \mathrm{CFR}$ 265.93(d)(7)(i)."

28. Page 1.1, Section 1.1, $3^{\text {td }}$ paragraph. Re-write the fourth sentence as: "In addition, information gained during the assessment monitoring program (including the further determinations), could be used to evaluate comective measures."

29. Figures 1.1, 1.2, 3.6, and 3.7. The figures don't appear to include pertinent ancillary equipment. In particular, at least one figure should show where unplanred releases have occurred in relation to the management of the S-SX tarks and/or ancillary equipinent. For example, as an unplanned release occurred around the 241-S-151 diversion box, this area denoted on a figure would provide pertinent information to this assessment. Table 3 of Vadose Zone Characterization Project at the Hanford Tank Farms SX Tank Farm Report (DOE/D/12584 GJPO-HAN-4, September 1996) describes unplanned releases associated with the management of the SX tank farm and Figure 2 of the same report identifies the locations of more than a dozen releases.

30. Figure 1.2. A compariton of the well numbers shown on Figure 1.2 and the wells described in Appendix D of Assessment Groundwater Monitoring Plan for Single Shell Tank Waste management area S-SX (WHC-SD-EN-AP-191, Rev. 0) was performed. The referenced document identifies well numbers 299-W22-6, 299W22-16, and 299-W23-8, which do not appear to be shown on Figure 1.2. Well number confimation and inclusion on Figure 1.2, if applicable, is requested.

31. Figure 1.2. Figure 2 of Vadose Zone Characterization Project at the Hanford Tank Farms SX Tank Form Report, September 1996, DOE/ID/12584-268 GJPOHAN-4, shows 216-S-8 trench located just northeast of tank 104. Figure 1.2 shows 216-S-8 trench located southeast of tank 104. Similarly, Figure 1.2 shows well 299-W22-39 located just west of 216-S-8 trench and Figure 2 shows well 
299-W22-39 located approximately 200 feet south of 216-S-8 trench. Confirm the accuracy of Figure 2's location of 216-S-8 trench and well 299-W22-39.

32. Page 1.3, Section 1.2, $1^{\text {st }}$ paragraph. In the first sentence, include the identification that observed contamination concentrations were also considered. Recommended wording is: "....if observed concentrations of contaminants and changes in groundwater quality....".

33. Page 1.3, Section 1.2, $1^{\text {st }}$ paragraph. Change "Phase $\Gamma$ " to "first determination" in the second sentence.

34. Page 1.3, Section 1.2, $2^{\text {nd }}$ paragraph. As this report represents the first determination of the assessment monitoring program, it should not be limited to a description of "new information". Recommended wording for the first sentence is: "The scope of this report focuses on new information acquired in connection with the first determination assessment.

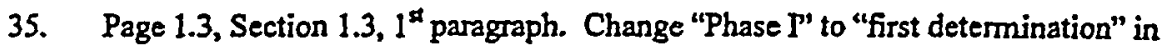
the first sentence.

36. Page 2.1, Section 2.0, $1^{\text {st }}$ paragraph. Change "Phase $\Gamma$ ' to "first determination" in the first sentence.

37. Page 2.1, Section 2.0, $1^{\text {In }}$ paragraph. The use of a DQO process is described whereby a conceptual model will be generated as the investigation continues. The second sentence of this paragraph should be moved to Chapter 6 of this document. The further determination actions (required by 40 CFR 165.93(d)(7)(i)) should be described in detail in Chapter 6.

38. Page 2.1, Section 2.0, $2^{\text {nd }}$ paragraph. Change "Phase $P$ " to "first determination" in the first sentence.

39. Page 2.1, Section 2.1.1. What Does CWR stand for?

40. Page 2.5, Section 2.2. Please discuss the leak volumes for S/SX tank farm. Also, add a discussion of the Agnew report on the underestimation of releases from this tank farm.

41. Pages 2.5-2.5, Section 2.2. Section 3.8 (page 3.18) appears to describe contaminant transport as a plume. The vadose zone characterization information from BX, BY, TX, TY, T and SX suggests that contamination has moved as broad, low-activity plumes. While Section 3.8 appears to be describing this conceptualization, it does not do so clearly. Similarly, Section 2.2 does not appear to include this conceptualization, but rather, it emphasizes the non-homogeneous nature of the sedimentary units beneath the units as playing an important role in 
contaminant movement. Similarly, Figures 3.9 and 3.10 emphasize this concept by implying the stratigraphic layers control contaminant transport. Include a conceptualization of plume migration in a relatively homogeneous fashion. It should be noted that this concept does not negate, but rather compliments, the expert panel's concept. The voluminous vadose zone characterization information may be referenced in relation to the "relatively" homogenous plume migration concept.

42. Page 2.4, Section 2.1.1, $3^{\text {rd }}$ and $6^{\text {th }}$ paragraphs. Figure 1.2 is identified as showing SX tank farm leakers but does not appear to identify designated leakers. Figure

- 3.6 shows designated leakers and would be a better figure to reference.

43. Page 2.4, Section 2.1.1, $6^{\text {th }}$ paragraph Delete the word "potential" in the first sentence, as there is no question that groundwater beneath the S-SX WMA has been and remains contaminated.

44. Page 2.4, Section 2.1.1, $6^{\text {th }}$ paragraph. Although considerable vadose zone characterization information bas been documented, only two DOE reports are referenced in the last sentence of the paragraph. The following additional reports/documents should also be referenced and/or discussed in this assessment: 1) Tank Summary Data Report for Tank SX-102, October 1995 (GJ-HAN-6, Tank SX-102), 2) Tank Summary Data Report for Tank SX-108, November 1995 (GJHAN-10, Tank SX-108), 3) Tank Summary Data Report for Tank SX-109, December 1995 (GJ-HAN-11, Tank SX-109), 4) Tank Summary Data Report for Tank SX-110, December 1995 (GJ-HAN-12, Tank SX-110), 5) Tank Summary Data Report for Tank SX-110, December 1995 (GJ-HAN-13, Tank SX-111), 6) Tank Summary Data Report for Tank SX-115, January 1996, (GJ-HAN-17, Tank SX-115), 7) Assessment of Log Data for Borehole 41-09-39 and Correlation With Borehole 41-09-04 in the SX Tank Farm, March 1997 (GJO-97-4-TAR, GJOHAN-9) and 8) Reassessment of the Vadose Zone Contamination at Tank SX-104 and a Comparison to the 1995 Baseline, April 1998 (GJO-98-48-TAR, GJOHAN-21).

45. Page 2.5, Section 2.1.1, paragraph from preceding page. Insert "groundwater and/or" between "contributors to" and "vadose zone contamination" in the first complete sentence on the page.

46. Page 2.5, Section 2.1.2, $1^{\text {st }}$ and $2^{\text {nd }}$ paragraphs. The possible dissolution and precipitation of silica and aluminum in the soil column is discussed/described. An identification of an unusually high silica percentage in drill cuttings (at depth) has not been made. Include the identification of all applicable observations from drill cuttings (i.e., the observation(s) of the occurrence of high silica content, the observation(s) of occurrence of average silica content, and/or the observation(s) of low silica content). It is noted that the proposed activities as described in the Assessment Groundwater Monitoring Plan for Single Shell Tank Waste 
management Area S-SX (WHC-SD-EN-AP-191, Rev. 0) do not appear to specifically collect silica content observations. Nonetheless, if observations were made, include them and if no observations were made, include the identification of this status.

47. Page 2, Section 2.1.2, First and second paragraph. It is an established fact that multi-molar high caustic liquids dissoive silica and aluminum.'Under vadose conditions, we should expect precipitation of these materials at depth (silica nodules, colloidal silica, silica as binding cement, etc.). Did we observe any unusually high silica percentages in drill cuttings at depth? If this was not observed, it is highly probable that the entire mass of tank leakage have rnoved downward as a wetting front. This wetting front need not necessarily be as broad as mentioned in the text.

48. Page 2.5, Section 2.1.2, $2^{\text {nd }}$ paragraph. Identify the basis for the deseriptor "broad" used in the first sentence in relation to the "wetting front". The basis should be included in the text discussion.

49. Page 2.2, Figure 2.1. While the conceptualized model of contaminant transport through the soil to the groundwater correctly identifies contaminated groundwater, which satisfies the purpose of the first determination, it appears the model is greatly simplified. Although the model is identified as representing spills/leakage during the 1960's (with subsequent movement of contaminants shown in single colors based on the likely rate of transport through the soil), it does not communicate that there have been numerous releases in and around the S-SX WMA beginning in the 1950's to the last documented unplanned release in 1980 . While it is accurate to depict groundwater contamination of mobile constituents, less mobile constituents have also been observed in groundwater. In particular, cesiurm-137 and strontium-90 have been measured numerous times in the groundwater at several locations. In addition, the contaminant transport is greatly complicated by the potential complex geochemical reactions oceurring in the subsurface, the complex configuration of tank ancillary equipment, numerous spills and/or leaks which have occurred in and near the S-SX WMA, etc. Perhaps the most deficient aspect about the conceptualized model is that it doesn't accurately depict that releases have occurred numerous times and each time potentially re-starting and/or promoting contaminant transport. Using overlays that depict the passage of time and new occurrences may best depict such a reoccurring contaminant front moving through the vadose and into the groundwater. At a minimum, the figure must identify that the conceptualized model is a simplified one that only depicts one potential "generation" of contaminant transport through the vadose zone.

50. Page 2.5 , Section $2.1 .2,4^{\text {th }}$ paragraph. Insert the words "(S-SX tank systein ancillary equipment) between "outlets of the tanks" and "also contributed to". 
51. Page 2.6, Section 2.2, $1^{\text {st }}$ full paragraph. The second senterce states "five wells were drilled to groundwater in the $S$ and $S X$ farms, three of which are adjacent to tanks". According to Figure 1.2 and information contained in the Assessment Groundwater Monitoring Plan for Single Shell Tank Waste management Area S$S X$ (WHC-SD-EN-AP-191, Rev. 0), there are six groundwater wells in the $S$ and SX farms, four of which are adjacent to tanks.

52. Page 2.6, Section 2.3, $1^{\text {st }}$ paragraph. Change the wording in the first sentence to include spills and leaks of water and/or wastes. Recommended wording is:

"....or a leak and/or spill (water and/or waste) of sufficient....".

53. Page 2.6, Section 2.4, $1^{x}$ paragraph. Change the word "co-contaminants" to "constituents" in the second sentence.

54. Page 2.6, Section 2.4, $1^{\text {* }}$ paragraph. Insert "While radionuclide constituents

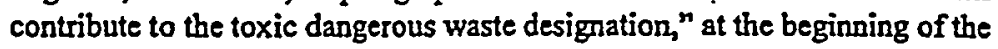
sentence. In addition, change "hazardous waste constituents (or listed wastes)" to "Yoxicity characteristic contaminants" in the third sentence. Recommended wording for the third sentence is: "While radionuelide constituents contribute to the toxic dangerous waste designation, the latter two constituents are RCRA toxicity characteristic contaminants."

55. Page 2.6, Section 2.4, $1^{\text {tt }}$ paragraph. The fourth sentence implies that pastpractice discharges of tritium-bearing tank condensate have occurred upgradient from all S-SX WMA groundwater monitoring wells. From information available, it appears the tritium-releasing unit of reference is the $216-\mathrm{S}-25$ crib. It may be conciuded that the crib is directly upgradient from the SX tank farm and upgradient from only part of the $S$ tank farm. Therefore, recommended wording for the fourth sentence is the following: "Tritium also is present in the tank waste, but a much larger tritium source (past-practice tritium-bearing tank condensate discharges to 216-S-25 crib) has been located directly upgradient from the SX tank farm (Hanford Site Groundwater Monitoring for Fiscal Year 1997, Plate 3).

56. Page 2.6 , Section $2.4,1^{\text {tt }}$ paragraph. It is noted that $216-\mathrm{S}-25$ crib is directly upgradient from $S X$ tank farm and upgradient from only part of $S$ tank farm. The tritium plots for the 1995, 1996, and 1997 Hanford Site groundwater monitoring reports (Plate 3) appear to be indicating an upward tritium trend in the area near well 299-W23-1. The same upward trend does not appear to be observed near upgradient well 299-W23-13 (located between upgradient tritium source 216-S-21 and S-SX WMA). As such, include a discussion of the tritium plume, the tritium to technetium-99 ratios, and the expectations associated with the hydraulic conductivity at well 299-W23-1. In particular, if there is a basis for the implied groundwater flow direction perturbation, include the basis. 
57. Page 2.7, Section 2.4, $1^{\text {st }}$ paragraph. Change the word "co-contaminants" to "constituents" in the first sentence.

58. Chapter 3. A section, which describes the groundwater monitoring network, should be inserted into this report. While it is appropriate to reference previously published documents for detailed information (i.e., Assessment Groundwater Monitoring Plan for Single Shell Tank Waste management Area S-SX (WHC-SDEN-AP-191, Rev. 0), without discussion and/or explanation, various erroneous conclusions may be drawn from the report. For example, considering certain text, figures and plots provided in the report, it appears to imply that monitoring well 299-W22-44 is "downgradient" to the S-SX WMA. While certain figures clearly show the expected path of groundwater plume migration (Figure 4.1) to be away from well 299-W22-44, other figures imply the well is downgradient (Figures 3.1 and 3.3). It is noted that well 299 -W22-44 would not satisfy compliance point monitoring of WAC 173-303-645. Similarly, monitoring well 299-W23-15 could be considered to monitor only the southwestern-most comer of the S-SX WMA. While Figures 4.1 and 4.2 show plausible hypothetical groundwater plumes to explain the observations from well 299-W23-15, a description of the groundwater monitoring network which more clearly identifies what areas (spills and/or releases) and which tanks/ancillary equipment the monitoring wells are "monitoring" is very much needed in this chapter.

59. Page 3.1, Section 3.0, $1^{\text {st }}$ paragraph. Delete the term "Phase $\Gamma^{\prime}$ " and replace it with "first determination".

60. Page 3.1, Section 3.0, $1^{\text {st }}$ paragraph. Although the contractor was contracted to perform work from August 1996 to 1997, it is Ecology's position that statistical exceedances (between up- and down-gradient wells) have been occurring since 1991 (Ecology, May 24, 1996). Therefore, the first determination may be concluded to have been occurring well before August 1996. Either delete "(August 1996 to August 1997)" or replace it with "(1991-1998)".

61. Page 3.1, Section 3.1, title of section. Change the word "co-contaminant" to "waste constituent".

62. Page 3.1, Section 3.1. Include an identification that groundwater samples have been filtered since early 1995. Describe the filtration process. Also, include a discussion of how filtration typically lowers the measurement of metallic ion concentrations. It is noted that all chromium drinking water exceedances (from wells 299-W23-14, 299-W22-39, 299-W23-15, 299-W22-44, 299-W22-45, and 299-W23-1 which occurred from 1991 to present were unfiltered samples.

63. Page 3.1, Section 3.1, 1" paragraph. Change the word "co-contaminants" to "constituents" in the first sentence. 
64. Page 3.1, Section 3.1, $2^{\text {nd }}$ paragraph. Tanks SX-108 and 109 are indicated as "the primary single-shell tank leak sources". As there is a history of spills and releases from other tanks in the $\mathrm{SX}$ tank farm, the basis for this particular statement must be included.

65. Page 3.1, Section 3.1, $2^{\text {nd }}$ paragraph. Due to the significance associated with data collected by bailing versus purge and pump, include an appendix to the report that identifies how the various wells were sampled.

66. Page 3.1, Section 3.1, $3^{\text {rd }}$ paragraph. Well $299-W 23-1$ is noted in the last paragraph as the only well in the vicinity of WMA S-SX currently showing an upward trend. Include an identification that an upward tritium trend has been observed at wells 299-W23-1, 299-W22-39, and 299-W22-45. An upward tritium trend has been observed at well 299-W22-39 since March 1994.

67. Page 3.1, Section 3.2, 1" paragraph. Change the word "co-contaminants" to "constituents" in the first sentence.

68. Page 3.4, Section 3.2. In a short summary, state what is the point of this section as it specifically relates to $\mathrm{S} / \mathrm{SX}$.

69. Page 3.4, Section 3.3, Figure 3.3. Include plots for tritium data collected from wells 299-W23-13 and 299-W23-1.

70. Page 3.4, Section 3.3. Add a discussion of tritium observations (upward trend in downgradient wells) from wells 299-W23-13, 299-W23-1, 299- W22-39, and 299-W22-46. The tritium plots for the 1995, 1996, and 1997 Hanford Site groundwater monitoring reports (Plate 3 ) appear to be indicating an upward tritium trend in the area near well 299-W23-1.

71. Page 3.6, Section 3.4. It is recommended that concentration contours maps for tritium and technetium-99 for fiscal years ' 95 and ' 96 are added to the report.

72. Page 3.5, Section 3.4, $3^{\text {rd }}$ paragraph. The first sentence states the source areas for tritium and technetium-99 are clearly evident. Due to the '95, '96, and '97 Hanford Site groundwater monitoring reports (Plate 3 ) which show a trending . tritium plume oceurring in the north-eastern side of the S-SX WMA, include an explanatory basis for this statement.

73. Page 3.5, Section 3.4, $3^{\text {rd }}$ paragraph. Delete the word "appears" in the second sentence. Recommended wording is: "Groundwater monitoring observations strongly suggest technetium- 99 originates in the $S$ and $S X$ tank farm area while the highest concentrations of tritium originate to the west of the WMA near the upgradient crib sources noted above." 
74. Page 3.5, Section $3.4,3^{\text {rd }}$ paragraph. The third sentence identifies other major downgradient sounces and the fourth sentence provides an example of $a$ sidegradient source. Recommended wording is: "It should also be noted that other major down- and side-gradient sources exist, especially for technetium-99. For example, the technetium-99 contours near the upper right comer of Figure 3.4 originated from side-gradient past-practice disposal sites associated with U Plant operations."

75. Page 3.5, Section $3.4,4^{\text {th }}$ and $5^{\text {th }}$ paragraphs. The paragraphs do not appear to make any conclusions regarding the tritium observations. From Figure 3.5 , it may be inferred that there are two different sources. Therefore, it may also be inferred that there are two different sources of the technetium-99 and the tritium. Include a discussion of the observations related to the tritium trend in the northeastem area of the S-SX WMA.

76. Page 3.5, Section 3.4, $5^{\text {th }}$ paragraph. As the source of the technetium-99 has not been remediated, delete "(or was)" in the last sentence of the paragraph.

77. Figure 3.5. Upon review, the figure represents a useful generalization of observations. The text describing the figure indicates the data are an average of 1996 values for 12 wells. Considering the locations of the 12 data points and the statistical variation associated with the averaging (i.e., spatial and temporal), it is more accurate, at this time, to describe the information as representing a generalized relationship. In addition, it is indicated on page 3.5 that the expected tritium/technetium-99 ratio in downgradient wells is based upon "data and considerations provided in Agnew (1997)". Again, considering the potential error associated with the Agnew information, it is appropriate to describe the observed relationships as generalized and are to be evaluated/confirmed with additional data.

78. Figure 3.5. Figure 3.5 identifies data from well $299-W 22-21$ was used in its construction. Figure 1.2 does not appear to show this well. Include the well location on Figure 1.2.

79. Figure 3.5. The figure appears to include a data point for well 299-W22-10. According to Figure 1.2, this well appears to be downgradient to the 216-S-1,2 crib. Confirm if the well number is correctly indicated on Figure 3.5.

80. Figure 3.5. The data from well 299-W23-1 does not appear to be included in the plot. Include this well on the plot.

81. Figure 3.5. The data, if any exists, from well 299-W23-5, does not appear to have been included on the plot. If data exists for well 299-W23-5, include it on the plot. 
82. Page 3.9, Section 3.5.1, $1^{\text {Ix }}$ paragraph. The report does not appear to include hydrographs or data to explain the statement made in the second sentence concerming the declining water table. Include either data or hydrographs that reflect this information.

83. Page 3.9, Section 3.5.1, $1^{\text {th }}$ paragraph. The issue associated with the declining water table and the requirement to perform further assessments of the contamination (40 CFR 265.93(d)(T)(i) by reference of WAC 173-303-400) will need to be resolved. It does not appear that an evaluation of the rate of decline (i.e., the remaining well life) has been performed. Include an evaluation in this section of the report.

84. Page 3.9, Section 3.5.1: There seems to be large variability in the tritium values as evidenced from the table. An explanation is required to define this anomaly. There are other constituents, which also show some anomaly (e.g. nitrate and Cs). Whatever the anomaly, it is important to note that this data is for samples taken within 7 feet of the surface. Do you have any idea what is going on at greater depth?

85. Page 3.9, Section 3.5.2. The discussion identifies 'the net effect is for significant retention of cesium-137 and strontium-90 in the vadose zone.and/or on aquifer solids.' It is also noted that a tremendously large amount of information and data exist regarding the Cs-137 and St-90 vadose zone contamination. Therefore, include an identification in this section that Cs-137 and St-90 contamination has been confirmed in the vadose zone. In addition, include a reference in this section which identifies the Cs-137 and Sr-90 vadose zone contamination will be discussed in detail in Section 3.7 of this report.

86. Page 3.10, Table 3.1. The table's measured concentration for $1-129$ is indicated as 'NA' or not available. The HEIS database, however, indicates that sampling occurred and the results indicated values were below the detection limit of the analysis. Please update the table to reffect the 'less than detection limits' reported in HEIS.

87. Page 3.10, Table 3.1. The HEIS data indicates a May 23, 1997 tritium measurement of $64400 \mathrm{pCi} / \mathrm{L}$. Although it is unknown if the measurement was from the "normal" or "shallow" sampling depth, the measurement is not reflected in the table. Please explain this discrepancy.

88. Page 3.11, Section 3.5.2, Top of the page: The alternative theory is not clear. The salt matrix is supposed to cover the clay surfaces and would effect the $K_{\delta}$ values a phenomenon expected to occur mostly in the vadose zone (under the defined scenario). Please clarify the details of the altemative theory and explain its impact on the discussion. 
89. Page 3.11, Section 3.6: Although tritium plumes can substantiate to some extent the hydraulic conductivity information as presented in the figure, the other data (e.g. Tc-99) does not to support the conclusion. A superimposed plot of hydraulic conductivity and plume maps would clarify some of the conclusion made in this report. For example, it appears the mixture of hypothetical plumes of Tc-99 from tank leak and spill may occur closer to the Tank Farm (Figure 4.1) than depicted. Please clarify the language in this section to respond to these issues.

90. Page 3.13, Figure 3.8. On page 3.11 Figure 3.8 is based on information/data dating to or before 1992. If pump test data exists from newer boreholes, use all of the data to update this figure (i.e., to evaluate permeability variation).

91. Page 3.14-3.17, Section 3.7.2: It is not clear why the near surface gravel layer or deeper gravel layer (which is at/close to the water table) under the depicted scenario should act as conduit for lateral migration. In most cases the tanks are on top of the gravel layer. Some lateral migration might take place at the boundary of gravel layer and sand. This is unlikely since the conductivities and porosities are usually higher in sand than gravel. Does any field data exist to substantiate the premise in this section? If so, include the data and a more detailed explanation of the phenomena.

Was any perched water encountered (or very high soil moisture near the surface gravel layer, etc.)? From the observation of numerous crib (CERCLA) sites where millions of gallons of waste were discharged to the soil column, there is no evidence of having a perched water table or any similar hydrogeologic phenomenon close to the surface in the 200 Area. Include a discussion of these issues in this section.

92. Page 3.14, Section 3.7.1, $2^{\text {nd }}$ paragraph. Include the actual measured concentrations of borehole $41-09-39$ in the discussion particularly as it relates to the statement that concentrations were 1,000 to 10,000 times lower than maximum concentrations that occur above the gravel sequence. The last part of this paragraph is not clear. What do you mean by increase of likelihood of breakthrough to ground water? When you pump groundwater, you increase the vadose thickness and capillary fringe zone (shifting) above the water table. This section needs clarification.

93. Page 3.14, Section 3.7.1, $2^{\text {nd }}$ paragraph. Initial groundwater samples at the top of the aquifer indicate hexavalent chromium is non-detectable $(<10 \mu g / \mathrm{L})$ from borehole 41-09-39. It is not indicated whether or not the samples were filtered. The groundwater data as identified in HEIS indicates the groundwater samples for chromium have been filtered (wells 299-W22-46, 299-W22-39, 299-W22-45, 299-W23-15, and 299-W23-14) since early 1994. In addition, chromium concentrations measured at well 299-W23-7 in June 1996 were unfiltered and exceeded $(53 \mu \mathrm{g} / \mathrm{L})$ the chromium drinking water standard $(.05 \mathrm{mg} / \mathrm{L})$. Similarly, 
chromium concentrations measured at well 299-W22-39 in November 1991, January 1992, July 1992, November 1992, June 1993, and March 1994 were unfiltered and exceeded $(60,83,380,100,160$, and $200 \mu \mathrm{g} / \mathrm{L}$ respectively) the chromium drinking water standard. Similarly, chromium concentrations measured at well 299-W22-46 in July 1992, November 1992, March 1993, June 1993 , and March 1994 were unfiltered and exceeded $(72,70,120,130$, and 120 $\mu g / \mathrm{L}$ respectively) the chromium drinking water standard. Therefore, identify if the sample(s) from borehole 41-09-39 were filtered. If filtered, include a discussion regarding the above observations including general conclusions of the effect of filtration related to ion measurements.

94. Pages 3.15 and 3.16, Figures 3.9 and 3.10. Figure 3.9 depicts contamination above $1 \mathrm{pCi} / \mathrm{g}$ and Figure 3.10 depicts contamination above $10 \mathrm{pCi} / \mathrm{g}$. Due to the voluminous vadose zone characterization information available, the figures must either be redrawn to depict detectable low-level contamination below $1 \mathrm{pCi} / \mathrm{g}$ or provide a technical basis which justifies the non-importance of understanding low-level contamination in relation to the physical and chemical mechanisms of contaminant transport. Similarly, Figure 3.10 must be redrawn to include Cs-137 measurements above $10,000 \mathrm{pCi} / \mathrm{g}$. The re-drawing should depict the high levels of contamination measured at boreholes 41-07-07, 41-09-09, and 41-00-08.

95. Pages 3.15 and 3.16, Figures 3.9 and 3.10. The figures depict a contamination perching effect occurring above the gravel and sandy gravel layers. The figures tend to depict the gravel and sandy gravel layers as conduits for lateral migration. While some degree of lateral migration may occur at such interface changes, the figures imply a relatively significant stratigraphic control. Include the basis for these interpretations (i.e., contaminant concentrations and/or moisture content . measurements, perched water observations during drilling, etc.).

96. Pages 3.16, Figure 3.10. Figure 3.10 does not appear to include data from borehole 41-09-09. Either include this borehole data or provide justification for its exclusion.

97. Page 3.14, Section 3.7.2, $1^{\text {tt }}$ paragraph. After Figure 3.10 is re-drawn to reflect additional contamination data, include an identification that the postulated stratigraphic control near tank S-104 is not as highly correlated as expected.

98. Page 3.17, Section 3.7.3 Please discuss the increased amount infiltration in nonvegetated gravel tank farms. Discuss also the increase in infiltration due to umbrella effect of tank impervious domes. Increased impervious area concentrates recharge between tanks.

99. . Page 3.17, Section 3.7.3, $2^{\text {nd }}$ paragraph: There seems to be noticeable differences in soil moisture between shallow and deeper parts in certain wells (section AA, wells W23-14, and W22-39). Explain the observation. 
100. Page 3.18, Section 3.8. Include an identification that the circumstantial evidence being referred to is the interpretation of data as depicted in Figures 3.9 and 3.10 which appears to be primarily based upon the contamination measured at borehole 41-09-39. This section should also include an identification that there is also considerably more circumstantial evidence that indicates there are numerous regions of "deep" contamination at the SX tank farm. This section should also identify that borehole 41-09-39 represents the deepest borehole from which vadose zone characterization information has been obtained and the vertical plume depicted in Figure 3.10 may largely be due to the lack of additional deep vadose zone data. This section should include a conclusion that it is not known at this time if the contamination is primarily transported via small vertical structures or if it occurs as a relatively large homogeneous plume.

101. Page 3.18, Section 3.8: Recently, PNNL has collected a lot of information and values on $\mathrm{K}_{d} \mathrm{~s}$ of a number of compounds/analytes that are more reasonable to use under different conditions. Use these values for consistency and accuracy.

102. Section 3.8. The section discusses technetium-99, cesium-137 and strontium-90 in relation to contaminant breakthrough. Although the chemical constituents are discussed in relation to analytical results in Appendix B, Section 3.8 does not reference the Appendix $B$ constituents as contaminants which have been detected in the groundwater. In addition, Appendix B only contains data from '96 to '97, although much more data exists. Furthermore, pre-1996 groundwater data has been used in several sections of the document to discuss constituent patterns and relationships. Therefore, include a discussion of groundwater contaminant observations.

Aluminum represents an example of a groundwater constituent that should be discussed in the report. The HEIS data indicates aluminum concentrations have been measured since 1987. Aluminum observations range from non-detect (approximately $20 \mu \mathrm{g} / \mathrm{L}$ ) to $13,000 \mu \mathrm{g} / \mathrm{L}$ (March 1994) and 18,300 $\mu \mathrm{g} / \mathrm{L}$ (May 1997). From the HEIS entries, it appears groundwater samples were filtered beginning March 1994. With a few exceptions, filtered aluminum concentrations have been non-detect to relatively low compared to the non-filtered concentrations. The filtered groundwater samples may generally be described as resulting in aluminum measurements that are typically more than an order of magnitude lower than the non-filtered groundwater samples. In conclusion, the aluminum summary provided in Appendix B of the report incorrectly identifies that most of the aluminum results "are at or near detection limit". Describe all of the data and include a trend analysis of non-filtered aluminum measurements, if applicable.

Carbon tetrachloride also represents an example of a groundwater constituent occurring in the S-SX WMA monitoring wells that should be discussed in the 
report. The HEIS data indicates carbon tetrachloride concentrations have been measured since 1992 at both up and downgradient S-SX WMA groundwater monitoring wells. Although measurements were not made consistently (from the same wells or at the same frequency), the observations collected thus far indicate that concentrations of carbon tetrachloride in downgradient wells have been greater than the respective concentrations observed in upgradient well 299-W-14 on at least two occasions (it should also be noted that carbon tetrachloride concentrations in upgradient well 299-W23-14 bave only been measured four times since 1992). Furthermore, water quality standards for groundwater as established by WAC 173-200 for carbon tetracholoride $(.3 \mu \mathrm{g} / \mathrm{L})$ have been exceeded since 1997 by two orders of magnitude in well 299-W23-15. Carbon tetrachloride measurements as recorded in the Tank Waste Information Network System (TWNS) indicate that of the two tank farms (S and SX), only samples/cores from one tank (S-104) have been analyzed for carbon tetrachloride. Review of the core sample data indicates carbon tetrachloride was not detected. Similarly, TWINS data for vapor analyses indicates carbon tetrachloride was detected in the tank vapor headspace of tanks S-102 and S-106. It should be noted that the review of the TWINS data indicates that the vapor headspace of only seven tanks (SX-1, S-101, S-102, S-103, S-106, S-111, and S-112) were analyzed. A further review of the HEIS data has indicated that carbon tetrachloride has also been found in the 216-S-25 crib groundwater monitoring wells. The data also indicates the first 216-S-25 crib carbon tetrachloride observation occurred in July $1993(1.2 \mu \mathrm{g} / \mathrm{L})$ at well 299-W23-10. In comparison, the data indicates the first SSX WMA carbon tetrachloride observation occurred in January $1992(2.9 \mu \mathrm{g} / \mathrm{L})$. Therefore, the report must include a discussion of carbon tetrachloride observations from the S-SX WMA and 216-S-25 crib groundwater monitoring network wells. In addition, the discussion should include the TWINS data base information regarding carbon tetrachloride analyses with an indication of which tank wastes and/or headspaces were sampled. In addition, if vadose zone carbon tetrachloride data exists, that data should also be included in the discussion.

Nitrate, potassium, and fluoride should also be discussed in this report. In particular, it is appropriate to statistically compare the upgradient to the downgradient concentrations.

103. Page 4.1, Section 4.1, $1^{\text {It }}$ paragraph. Delete the term "Phase $\Gamma$ " as it has no regulatory meaning. Recommended wording for the first sentence is: "As part of this first determination groundwater assessment, an attempt..."

104. Page 4.1, Section 4.1, $1^{\text {n }}$ paragraph. As more hypothetical scenarios exist to explain the contamination observations, recommended wording for the second sentence is: "For this purpose, the following three scenarios are considered:".

105. Page 4.1, Section 4.1.1, $1^{\text {2t }}$ paragraph. Identify that the "SX Tank Farm Report" (DOE/D/12584-268; GJPO-HAN-4, September 1996) tank-by-tank vadose zone 
characterization discussions (Section 10.2) do not support this scenario. It should also note that the report identifies substantial surface contamination above most SX tanks, which does not appear to be addressed by this scenario.

106. Page 4.1, Section 4.1.2, $1^{\text {th }}$ paragraph. Identify that the "SX Tank Farm Report" (DOE/M/12584-268, GJPO-HAN-4, September 1996) tank-by-tank vadose zone characterization discussions (Section 10.2) do not support this scenario. It should also note that the report identifies substantial surface contamination above most SX tanks, which does not appear to be addressed by this scenario.

107. Page 4.3, Section 4.1.3, $1^{\text {st }}$ paragraph. Identify that the "SX Tank Farm Report" (DOE/ID/12584-268, GJPO-HAN-4, September 1996) tank-by-tank vadose zone characterization discussions (Section 10.2) do not support this scenario. It should also note that the report identifies substantial surface contamination above most SX tanks, which does not appear to be addressed by this scenario.

108. Page 4.5; Section 4.2.1, $2^{\text {nd }}$ paragraph. Identify the potential pore volume associated with utility line leakage. From the discussion occurring in Section 4.2.2, line leakage may easily represent multiple pore volumes. Recommended wording to add to the end of the second paragraph is: "It should be noted that this comparison does not include consideration of utility line leakage."

109. Page 4.5, Section 4.2.2, $1^{\text {st }}$ paragraph. The last sentence indicates a high potential for a significant volume of utility line leakage. If records and/or estimates of volumes associated with this practice exist, they should be included as an appendix to this report.

110. Pages 4.5 - 4.9, Section 4.2.2. The discussion of utility line leakage and the comparison to specific conductivity observations is particularly important 1 ) in understanding contaminant transport and 2) for identifying objectives associated with future monitoring of the contamination plumes.

The first full paragraph on page 4.7 describes an eight-foot cottonwood tree and Figure 4.4 provides a photograph of the tree flourishing among the sagebrush. From this information, an approximation of the age of the tree and the water required for the tree to survive may be made. It is requested that these approximations be included in the report.

Specific conductivity as an indicator parameter should be discussed and/or analyzed in more detail. The discussion should include data analyses and an evaluation of all specific conductivity measurements (which began in 1994 at well 299-W23-14, 1992 at well 299-W23-15, 1992 at well 299-W22-45, 1992 at well 299-W22-21, 1991 at well 299-W22-39, and 1992 at well 299-W22-46). Section 4.2.2 provides a good, but incomplete discussion of specific conductivity observations and/or comparisons. Neither the discussion in Section 4.2.2 nor 
Appendix B provides an explanation or a derivation of the mean natural background value of $344 \mu \mathrm{mhos} / \mathrm{cm}$ for groundwater upgradient of Hanford facilities. More importantly, the assessment does not provide justification for using the mean natural background rather than the upgradient average background. Most importantly, the assessment report does not appear to compare specific conductivity observations from upgradient monitoring well 299-W23-14 to downgradient monitoring wells. Furthermore, the Appendix B discussion completely omits discussion of utility line contributions/effects to specific conductivity observations. The report must include all data used to derive the statistical mean for the upgradient well(s) and include an explanation and/or equation identifying how the specific conductivity measurements were averaged to obtain the background. Note: a cursory review of specific conductivity measurements collected from upgradient well 299-W23-14 from September 1994 to May 1998 yielded an average specific conductivity of $241 \mu \mathrm{mhos} / \mathrm{cm}$. This average falls within the stated "general background from a waste source" category range of 225-260 $\mu \mathrm{mhos} / \mathrm{cm}$. Also, a cursory review of specific conductivity measurements collected since 1994 indicates specific conductivity measurements from downgradient wells were consistently higher than from upgradient wells (299-W23-14 and 299-W23-13) until February 1996. Of interest, from February 1996 to May 1998, at RCRA downgradient wells 299-W23-15, 299-W22-46, and 299-W22-39, specific conductivity measurements were lower than those collected from RCRA upgradient well 299-W23-14.

The discussion on page 4.7 predicts lower observed values for specific conductivity measurements due to utility line leaks. This generalization appears to explain the observations for the SX tank farm, but lower specific conductivity values are not observed in $S$ tank farm downgradient monitoring wells (as reflected by Figure 4.3 and HEIS data). Therefore, it may be appropriate to apply two separate specific conductivity analyses (comparisons between upgradient and downgradient wells), one for the SX tank farm wells (299-W23-14, 299-W23-15, 299-W22-46, and 299-W22-39) and one for the S tank farm wells (299-W23-13, 299-W23-1, 299-W23-7, and 299-W22-45).

111. Page 4.7, Section 4.2.2, $2^{\text {nd }}$ full paragraph. The first sentence indicates the specific conductance in the vicinity of the $S$ and $S X$ tank farms is much lower than natural groundwater for the Hanford Site. Although it is agreed that the specific conductance is lower in the S-SX WMA area, this sub-section does not discuss any comparisons between up and downgradient wells. As a generalization, upgradient well 299-W23-13 specific conductivity measurements are lower than downgradient well 299-W22-45. Similarly, upgradient well 299W23-14 specific conductivity measurements are lower than downgradient wells 299-W23-15 (September 1994-August 1995), 299-W22-39 (September 1994February 1996), and 299-W22-46 (September 1994-August 1995 and November 1996-May 1998) and 299-W22-45 (September 1994-May 1998). Include a 
statistical evaluation to determine if any of the downgradient increases are statistically significant.

112. Page 4.6, Figure 4.3. The 1997 conductivity contour inset should identify that the 299-W23-7 measurement of $160 \mu \mathrm{mhos} / \mathrm{cm}$ represents the only measurement collected for 1997 and that it was collected by bailing. In addition, include an explanation how the contours were developed, (i.e., if all the well data were averaged).

113. Page 4.9, Section 4.2.3. The second paragraph indicates that well 299-W23-1 is an older well with a "poor or uncertain seal". Include an identification that the well was "remediated" in 1976 by perforating the 6-inch screen, installing a 4-inch casing, and grouting the annulus (Assessment Groundwater Monitoring Plan for Single Shell Tank Waste Management Area S-SX, WHC-SD-EN-AP-191, Rev.0). Also identify if there have been any measurements of gamma (in)retivity from well 299-W23-1.

114. Page 4.9, Section 4.2.3. According to Assessment Groundwater Monitoring Plan for Single Shell Tank Waste Management Area S-SX, WHC-SD-EN-AP-191, Rev.0, the "listed use" of many of the S-SX WMA groundwater monitoring wells were "SST monthly water level measurements". For example, groundwater level measurements were collected on a monthly basis at well 299-W23-6 from June 1989 to March 1993, well 299-W23-7 from July 1974 to March 1993, well 299W23-8 (which does not appear to be shown on Figure 1.2) from December 1989 to March 1993, well 299-W23-12 from July 1991 to March 1993, well 299-W2239 from July 1991 to March 1993, well 299-W22-45, well 299-W.22-46 from January 1992 to March 1993, well 299-W23-13 from July 1991 to March 1993, well 299-W23-14, from July 1991 to March 1993, well 299-W23-15 from January 1992 to March 1993, well 299-W23-2 from August 1955 to November 1992, and well 299-W23-3 from May 1956 to March 1993. Comparing the snow melt events to water level measurements (hydrographs) may yield correlations which may add to the discussion but are currently lacking.

115. Page 5.1, Section 5.0, $1^{n}$ paragraph. There is no regulatory basis for the term "Phase I". Replace the term with "first determination assessment of 40 CFR 265.93(d) (by reference of WAC 173-303-400)".

116. Page 5.1, Section $5.0,1^{\text {tt }}$ bullet. Radionuclides are considered to be waste constituents. Recommended wording for the first bullet is: "Distribution patterns for tank waste constituents (radionuclides, nitrate, chromate, etc.) in the vicinity of WMA S-SX indicate this WMA has contributed to groundwater contamination observed in downgradient monitoring wells."

117. Page S.1, Section 5.0, $2^{\text {nd }}$ bullet. Due to the spatial and temporal groundwater observations of contamination occurring at wells $299-$ W23-2 (1987-1989) and 
299-W23-7 (1987 - 1989), at least four WMA source areas are needed to explain the technetium-99 observations at well 299-W23-7 and the technetium-99 and nitrate observations at well 299-W23-2. Considering the spatial and temporal vadose zone observations of radionuclide contamination, there could easily be more than four "source areas". Re-write the bullet to identify the additional groundwater observations occurring at wells 299-W23-2 and 299-W23-7 and include the appropriate identification of the vadose zone characterization information.

118. Page 5.1, Section 5.0, $3^{\text {rd }}$ bullet. Please explain the drinking water standard of $45,000 \mu \mathrm{g} / \mathrm{L}$ used at this point. The groundwater quality criterion of WAC 173$200-040$ for nitrate (as $N$ ) is $10 \mathrm{mg} / \mathrm{L}$.

119. Page 5.1, Section $5.0,3^{\text {rd }}$ bullet. The bullet could be interpreted to imply there is a limitation to the contamination at and/or near wells 299-W22-46, 299-W23-6, and 299-W23-1. Tank waste constituents have re-occurred at wells 299-W23-1, 299-W22-39, 299-W22-46, 299-W23-7, etc. Include an identification of such reoccurrences in this bullet.

120. Page 5.1, Section 5.0, $3^{\text {rd }}$ bullet. An observation of nitrate higher than the water quality criteria ( $10 \mathrm{mg} /$ ) has occurred at well $299-W 23-3$ as recently as July 1995 (the most recent nitrate measurement at this well is $17 \mathrm{mg} / \mathrm{l}$ ). Similarly, the most recent nitrate observations at well 299-W23-2 (15 mg/ measured March 1996), at well 299-W23-15 (11 mg/l measured February 1996), at well 299-W22-39

(17mg/ measured February 1996) all exceeded water quality criteria. Therefore, although it has been more than two years after nitrate was measured at most of these wells, it is unknown if nitrate is currently limited to well 299-W22-46 at this time. Either describe the most recent nitrate measurements at wells 299-23-3, 299-W23-2, 299-W23-15, and 299-W22-39 or re-write the sentence to identify that the limit of the nitrate water quality standard exceedances is unknown at this time.

121. Page 5.1, Section 5.0, $4^{\text {th }}$ bullet. Either re-write the bullet to identify that since. February 1996 (with only one exception), the groundwater samples collected for chromium analysis have been filtered and the decrease noted will have to be confirmed by analysis of unfiltered samples. The other altemative is to delete chromium from this trend.

122. Page 5.1, Section 5.0, $4^{\text {t }}$ bullet. Delete the second sentence of the bullet. The identification of future actions/determinations should be placed in Section 6.0 .

123. Page 5.1, Section $5.0,5^{\text {th }}$ bullet. The term "short-term contaminant transients" is not clear. From the discussion and the data, perhaps "securring contaminant transport" or "a mechanism for recurring contaminant transport" is more 
applicable wording for this phenomenon. If the term "short-term contaminant transients" is used, also provide a definition or explanation of the term.

124. Page 5.1, Section 5.0, $6^{\text {th }}$ bullet. The HEIS data base indicates cesium-137 was detected at the following wells: 299-W22-46 (April 1992, July 1992, November 1992, and May 1997), 299-W22-39 (November 1991, January 1992, April 1992, and July 1992), and 299-W22-45 (April 1993). Identify and/or discuss these occurrences in relation to the conclusion.

125. Page 5.1 , Section $5.0,7^{\text {th }}$ bullet. According to the HEIS data base, low but detectable cesium-137 was also found in another old well 299-W23-1. Include this information in the bullet. Also, include an identification that extensive vadose zone characterization information exists which confirms the presence of broadly distributed cesium-137 contamination. While it is important to determine if there is a communication pathway via the groundwater monitoring well from the S-SX WMA to the aquifer, an identification of the characterized vadose zone and the brogd distribution of cesium-137 contamination should also be identified in this bullet or in another bullet.

126. Page 5.2. Again, nature and extent of contamination determination is needed for groundwater and soil zone.

127. Page 5.2, Section 5.0, $i^{\text {st }}$ bullet. Insert the word "constituents" between "waste" and "reached" in the first sentence of the bullet. Also, identify in this bullet if the chromium samples were filtered prior to analysis.

128. Page 5.2, Section 5.0, 2 nd bullet. Recommended re-wording is: "Further data are needed to monitor and/or determine the nature, extent, and source(s) of groundwater contamination (including recurrent contamination) attributed to WMA S-SX."

129. Section 6.0 , General Comment. Section 6 does not satisfy the requirements of 40 CFR 265.93(d) in that the proposed actions do not describe how the rate and extent of migrating contamination will be delineated and monitored. In addition, even though the first determination has occurred over an extended period of time and the confirmation of multiple releases from the S-SX WMA has been adequately substantiated, the section discusses a scenario by which the monitoring program may return to a "detection monitoring status". This implies either a lack of understanding of RCRA groundwater regulations or a conclusion that the S-SX . WMA has not released hazardous waste constituents to the groundwater. The option to return to an indicator parameter monitoring program (as allowed by 40 CFR 265.93(d)(6)) occurs only when the owner/operator determines, based on the results of the first determination that groundwater has not been impacted by the unit. To explain further, if "no hazardous waste or hazardous waste constituents from the facility have entered the groundwater," then the owner/operator "may 
reinstate the indicator evaluation program." Therefore, Section 6 should be rewritten to clearly identify what actions will be taken to delineate and monitor the rate and extent of migrating contamination from the S-SX WMA. For a minimum frequency of further determinations (of the assessment monitoring program), refer to 40 CFR $265.93(\mathrm{~d})(7)(\mathrm{i})$.

130. Page 6.1. This section is missing any discussion of nature and extent proposed plans for vadose zone.

131: Page 6.1. Criteria for returning WMA unit to detection monitoring are premature at this point. Emphasis should be put on defining nature extent of contamination and possible corrective action.

132. Page 6.1, Section 6.0 title. Recommended re-wording is: "Proposed Further Determinations".

133. Page 6.1, Section 6.0, $1^{\text {st }}$ paragraph. Recommended re-wording for the first sentence is: "The objectives of the proposed further determinations (required by 40 CER 265.93(d)(7)(i) (by reference of WAC 173-303-400]) are: 1) to further delineate the nature and extent of migrating contamination (vadose and groundwater) associated with the S-SX WMA to support possible corrective action actions and/or options; 2) to understand the geochemical reactions tank waste constituents undergo in the vadose zone and groundwater; 3) to determine the appropriate tank waste constituents, reaction products and/or indicator parameters (including frequencies) to monitor; and 4) to assess the fitness-for-use of older non-RCRA compliant wolls within the WMA."

134. Page 6.1, Section 6.0. $2^{\text {nd }}$ paragraph. Change "Phase In" to "further determinations of 40 CFR 265.93(d)(7)(i) (by reference of WAC 173-303-400)".

135. Page 6.1, Section $6.0,2^{\text {nd }}$ paragraph bullets. The bullets must clearly identify which groundwater monitoring wells will be sampled, the frequency (quarterly) of sampling, and the constituents and parameters to be monitored. Note: due to the past filtration of samples, the bullets must identify that groundwater samples will not be filtered.

136. Page 6.1, Section 6.0, $3^{\text {rd }}$ paragraph. Delete the first sentence that describes the three "if" scenarios by which indicator monitoring may be resumed. This is not an option as releases from the S-SX WMA to the groundwater have been confirmed.

137. Page 6.1, Section $6.0,3^{\text {rd }}$ paragraph. Well $299-$ W22-44 should be removed from the quarterly monitoring program, as the well does not adequately represent a downgradient well located at the S-SX WMA's "point of compliance". 
138. Page 6.1, Section 6.0, $3^{\text {td }}$ paragraph. The proposed upgrades should be based upon well-specific data and should clearly identify what work/upgrades will be performed on which wells.

139. Page 6.1 , Section $6.0,4^{\text {th }}$ paragraph bullets. The bullets need to describe and/or indicate specific actions. For example, the first bullet should identify which wells will be sampled for which constituents. As another example, the second bullet should either identify the conditions for the "if necessary" qualifier or remove the qualifier and identify that monthly measurements will be made. Note: due to the filtration of chromium, no determination can be made on any chromium concentration trends.

140. Page 6.1, Section $6.0,4^{\text {th }}$ paragraph, $3^{\text {ro }}$ bullet. Include the basis for using well 299-W23-9 as an upgradient well for constituent concentration comparison purposes. Considering the direction of groundwater flow and the location of well 299-W23-9, this well does not appear to represent a well that will yield a representation of groundwater quality passing the upgradient unit boundary of the S-SX WMA.

141. Page 6.1, Section $6.0,4^{\text {th }}$ paragraph, $4^{\text {th }}$ bullet. The large volume pumping is noted to be approximately 1040 gallons. Prior to approving this action, a plan describing how the well purging will be performed must be submitted for review. The plan should identify the rate of purging, a description of how purging will be performed, the sampling intervals, a description of well history, a description of well development, an identification of sampling parameters, etc.

142. Page 6.1 , Section $6.0,4^{\text {th }}$ paragraph, $5^{\text {th }}$ bullet. The selective moisture content measurement is noted. As moisture and/or water sources may account for periodic occurrences of groundwater contamination, a plan describing how the moisture logging will be performed across the $S$ and $S X$ farms must be submitted for teview prior to approval.

143. Section 6.0. Include an identification of actions to be taken to further delineate the rate and extent of migrating contamination in the vadose zone.

144. Section 6.0. Include an identification of actions to be taken to identify and eliminate potential water sources (i.e., leaking water lines, water logging, rupture events, etc.) within and around the tank farms.

145. Page 6.2. Regulators will approve this subsequent workplan for phase II. A discussion of how this phase II ties into an RFI process is needed. Also discuss how all of this will be tied into the site-wide permit process. 


\section{3}

146. Page 6.2. Owner operators of TSD facilities impacting groundwater are obligated to proceed to corrective action phase. This can be and should be self-imposed by the owner/operator. 
Appendix B

Disposition of Comments 


\section{Appendix B}

\section{Disposition of Comments}

This appendix contains the disposition of comments from the Washington State Department of Ecology (Ecology) on the initial Resource Compensation and Recovery Act (RCRA) groundwater quality assessment report for Waste Management Area S-SX (PNNL-11810) issued in January 1998. The comments and related issues raised by Ecology.(Appendix A) were first categorized. The comments were divided into the following general categories as shown in Table B.1.

1. Regulatory

2. Subsurface Physical Model

3. Data and Sampling Issues

4. Additional Data and Discussion

5. Scope Issues

6. Monitoring Well Network.

After developing a sense of the breadth and nature of the comments, the individual numbered comments were addressed one-by-one in Table B.2. The disposition of each numbered comment is documented in Table B.2 with supplemental narrative, graphics, and data tables.

While the detailed comment-by-comment disposition ensured that each numbered comment was addressed and the disposition documented, larger issues were evident in some comments. Accordingly, there is an Expanded Disposistion of Comments and Data Tables following Table B.2. 
Table B.1. Index Table for Ecology Comments

\begin{tabular}{|c|c|}
\hline Category & Comment Number \\
\hline Regulatory & $\begin{array}{l}1,2,3,4,5,6,7,8,9,10,11,14,16,17,18,19,21,22,23,24, \\
25,26,27 \cdot 32 \cdot 33,34,35,36,37,38,39,43,45,50,51,52,53, \\
54,55,57,59,60,61,63,67,73,74,76,103,104,108,111, \\
115,116,122,123,127,128,129,132,133,134,136,145\end{array}$ \\
\hline Subsurface Physical Model Description & $\begin{array}{l}41,44,46,47,48,49,85,88,91,94,95,97,98,99,100,101 \\
105,106,107,117\end{array}$ \\
\hline Data and Sampling Issues & $\begin{array}{l}11,12,13,62,65,84,86,92,93,102,118,120,121,124,125 \text {, } \\
127,135,139\end{array}$ \\
\hline Additional Data and Discussion & $\begin{array}{l}10,13,17,29,30,31,40,41,42,44,46,47,48,49,56,58,62, \\
64,66,68,69,70,71,72,75,77,78,79,80,81,82,83,84,85, \\
87,89,90,91,92,93,94,95,96,97,98,99,101,102,109, \\
110,112,113,114,117,119,124,135,138,139,141\end{array}$ \\
\hline Scope Issues & $3,15,20,28,37,126,129,130,131,133,142,143,144,146$ \\
\hline Monitoring Well Network & $58,137,140$ \\
\hline
\end{tabular}


Table B.2. Response Record and Cross-Reference Table

\begin{tabular}{|c|c|c|}
\hline $\begin{array}{l}\text { Comment } \\
\text { Number }\end{array}$ & Disposition & Reference in PNNL-12114 \\
\hline 1 & Comment incorporated. Appropriate CFR and WAC are referenced in PNNL-12114. & Sections $1.1,3.0$, and 4.0 \\
\hline 2 & Comment incorporated. The term "Phase I" (or "Phase II") is not used in PNNL-12114. & $\begin{array}{l}\text { Summary and Sections } 1.1 \text { ( } 5^{\text {th }} \text { para- } \\
\text { graph), } 1.2\left(2^{\text {nd }} \text { bullet }\right), 3.0 \text {, and } 4.0\end{array}$ \\
\hline 3 & $\begin{array}{l}\text { Report (PNNL-11810) documented the first determination evaluation of } 40 \text { CFR } 265.93(\mathrm{~d})(4) \text {. } \\
\text { PNNL-12114 describes further determinations of the assessment monitoring program of } \\
40 \text { CFR 265.93(7)(i). Recommended wording used in PNNL-12114. }\end{array}$ & PNNL-12114 (entire report) \\
\hline 4 & Comment incorporated. & Section $1.1\left(3^{\text {rd }}\right.$ paragraph $)$ \\
\hline 5 & Comment incorporated. & Section 1.1 ( $4^{\text {th }}$ paragraph) \\
\hline 6 & Comment incorporated (see disposition 2). & See references in comment 2 \\
\hline 7 & Comment incorporated. & Section 2.2.1 ( $1^{\text {st }}$ paragraph) \\
\hline 8 & Comment incorporated. & Section 1.1 ( $6^{\text {th }}$ paragraph $)$ \\
\hline 9 & $\begin{array}{l}\text { Comment incorporated. The } 900 \mathrm{pCi} / \mathrm{L} \text { standard cited for technetium- } 99 \text { was based on } \\
\text { 4-mrem/yr effective dose equivalent set for beta particles and photon activity (see Appen- } \\
\text { dix III, EPA Interim Primary Drinking Water Standards as referenced in } 40 \text { CFR } \\
265.92[b][1]) \text {. The } 900 \mathrm{pCi} / \mathrm{L} \text { standard for technetium- } 99 \text { is referred to as drinking water } \\
\text { standard in PNNL-12114 as requested by Ecology. }\end{array}$ & Section 2.2 (Figure 2.1) \\
\hline 10 & $\begin{array}{l}\text { Comment noted and incorporated. We used relevant data to the extent possible in } \\
\text { PNNL-1 1810. We did not limit the observations to RCRA wells nor to current data. For } \\
\text { example, Section 3.8.1 and Figure 3.11 (PNNL-11810) discussed gross beta patterns observed } \\
\text { in RCRA and non-RCRA wells over a longer period (1984-1997) and Appendix B provided } \\
\text { a listing of groundwater monitoring data (2/96-11/97) in RCRA and non-RCRA wells. } \\
\text { Pre-RCRA data in older wells were also discussed in Sections } 3.8 .2,4.1 .2 \text { and } 4.1 .3 \text { of } \\
\text { PNNL-11810). However, enhanced descriptions to address Ecology comment are provided } \\
\text { in PNNL-12114. }\end{array}$ & $\begin{array}{l}\text { Sections } 2.2 .2 \text { and } 2.2 .3 \text { (see discussion } \\
\text { of strontium-90, cesium-137, and alpha } \\
\text { emitters. Also, see discussion of } \\
\text { tritium/technetium- } 99 \text { observations) }\end{array}$ \\
\hline
\end{tabular}


Table B.2. (contd)

\begin{tabular}{|c|c|c|}
\hline $\begin{array}{l}\text { Comment } \\
\text { Number }\end{array}$ & Disposition & Reference in PNNL-12114 \\
\hline 11 & $\begin{array}{l}\text { Disagree. The drinking water standard of } 10 \mathrm{mg} / \mathrm{L} \text { is applicable to nitrate (reported as } \mathrm{N} \text { or } \\
\text { nitrogen in nitrate). The standard of } 45,000 \mu \mathrm{g} / \mathrm{L} \text { (or } 45 \mathrm{mg} / \mathrm{L} \text { ) is applicable to nitrate } \\
\text { (reported as } \mathrm{NO}_{3} \text { ). The drinking water standard has not been exceeded in wells } 299-\mathrm{W} 22-45 \text {, } \\
299-\mathrm{W} 22-39,299-\mathrm{W} 23-2 \text {, and } 299-\mathrm{W} 23-3 \text {. Earlier data (1957 to } 1986 \text { ) from well } 299-\mathrm{W} 23-3 \\
\text { were not used because the analytical method is "unknown" as shown in HEIS. In addition, we } \\
\text { do not have confidence in the quality of these data (i.e., documentation of QA/QC is inade- } \\
\text { quate). The drinking water standard for nitrate was exceeded in well } 299-\mathrm{W} 22-46 \text { since May } \\
1997 \text { (not from } 1992 \text { to } 1997 \text {, as noted by Ecology). }\end{array}$ & \\
\hline 12 & $\begin{array}{l}\text { Disagree. It would be inappropriate to use the unfiltered chromium results for a trend plot for } \\
\text { the following reasons. Hexavalent chromium is an anion and easily passes through a filter as } \\
\text { well as through a porous medium. It is the hexavalent form of chromium or } \mathrm{Cr}(\mathrm{VI}) \text { that is } \\
\text { toxic (a listed waste). The most common lower oxidation state, } \mathrm{Cr} \text { (III), has a strong affinity } \\
\text { for particulates. Also, hexavalent chromium was used in the chemical separations process and } \\
\text { much of it survives in the single shell tanks. The hexavalent form (filtered) is what is most } \\
\text { important from a regulatory standpoint. The drinking water standard of } 100 \mu \mathrm{g} / \mathrm{L} \text { is based on } \\
\text { hexavalent chromium. The filtering process separates the hexavalent chromium from the } \\
\text { bound or non-toxic form of chromium so that an appropriate comparison can be made between } \\
\text { the monitoring result and the relevant standard. The unfiltered chromium would also be } \\
\text { subject to random fluctuations due to the amount of particulate debris flushed from the } \\
\text { formation or well screen (also see Expanded Disposition of Comment } 93 \text { following this table). }\end{array}$ & \\
\hline 13 & Comment noted and incorporated (see disposition of comment 10). & $\begin{array}{l}\text { Section } 2.2 .2 \text { (see discussion of } \\
\text { strontium-90, cesium-137, and alpha } \\
\text { emitters) }\end{array}$ \\
\hline 14 & Comment incorporated (see disposition of comment 2). & $\begin{array}{l}\text { Sections } 1.1\left(5^{\text {th }} \text { paragraph }\right), 1.2\left(2^{\text {nd }}\right. \\
\text { bullet }), 3.0 \text { and } 4.0\end{array}$ \\
\hline 15 & $\begin{array}{l}\text { Characterization of the nature and extent and sources of contamination in the vadose zone is } \\
\text { more appropriate for the TWRS RFI work plan (now a TPA milestone). However, the part } \\
\text { that pertains to the on-going groundwater study is one of the objectives of the assessment plan } \\
\text { (PNNL-12114). }\end{array}$ & $\begin{array}{l}\text { PNNL-12114 (groundwater } \\
\text { component) }\end{array}$ \\
\hline
\end{tabular}


Table B.2. (contd)

\begin{tabular}{|c|c|c|}
\hline $\begin{array}{l}\text { Comment } \\
\text { Number }\end{array}$ & Disposition & Reference in PNNL-12114 \\
\hline 16 & Comment incorporated (see dispositions of comment 1 and 6 ). & Sections $1.1,3.0$, and 4.0 \\
\hline 17 & Comment noted and incorporated (see disposition of comment 10). & Section 2.2.2 and 2.2.3 \\
\hline 18 & Comment incorporated (see disposition of comment 4). & Section 1.1 ( $3^{\text {rd }}$ paragraph $)$ \\
\hline 19 & Comment noted. & \\
\hline 20 & Comment noted (see disposition of comment 15). & $\begin{array}{l}\text { PNNL-12114 (groundwater } \\
\text { component) }\end{array}$ \\
\hline 21 & Comment incorporated. & Section 1.1 ( $1^{\text {st }}$ and $3^{\text {rd }}$ paragraph $)$ \\
\hline 22 & Comment incorporated. & Section 1.1 ( $3^{\text {rd }}$ paragraph $)$ \\
\hline 23 & $\begin{array}{l}\text { Disagree. The subject of this assessment report (PNNL-11810) was the first determination } \\
\text { allowed under RCRA regulations [40 CFR 265.93 (d)(4) and by reference of WAC 173-303- } \\
\text { 400(3)]. RCRA groundwater monitoring in compliance with requirements specified in } \\
40 \text { CFR 265, Subpart F [by reference of WAC } 173-303-400(3) \text { ] was initiated in 1990. Prior } \\
\text { to the Tri-Party Agreement of } 1989 \text { groundwater monitoring was conducted in accordance } \\
\text { with Atomic Energy Act of } 1954 \text { and subsequent DOE guidance. }\end{array}$ & . \\
\hline 24 & Comment noted. & \\
\hline 25 & Comment incorporated. & Summary ( $2^{\text {nd }}$ paragraph) \\
\hline 26 & Comment incorporated (see disposition of comment 2). & $\begin{array}{l}\text { Sections } 1.1\left(5^{\text {th }} \text { paragraph }\right), 1.2\left(2^{\text {nd }}\right. \\
\text { bullet }), 3.0 \text { and } 4.0\end{array}$ \\
\hline 27 & Comment incorporated. & $\begin{array}{l}\text { Section } 1.1\left(5^{\text {th }} \text { paragraph }\right) \text { and } 1.2\left(2^{\text {nd }}\right. \\
\text { bullet })\end{array}$ \\
\hline 28 & $\begin{array}{l}\text { This is the subject of new Tri-Party Agreement milestones that include development of an } \\
\text { RFI/CMS work plan to address this and related issues. }\end{array}$ & Beyond scope \\
\hline 29 & Comment incorporated. Unplanned releases were added in PNNL-12114. & Figure 5.3 \\
\hline
\end{tabular}


Table B.2. (contd)

\begin{tabular}{|c|c|c|}
\hline $\begin{array}{l}\text { Comment } \\
\text { Number }\end{array}$ & Disposition & Reference in PNNL-12114 \\
\hline 30 & $\begin{array}{l}\text { Comment incorporated. Wells } 299-\text { W22-6, 299-W22-16, and 299-W23-8 were added in } \\
\text { PNNL-12114. }\end{array}$ & Figure 1.2 and Figure 5.3 \\
\hline 31 & $\begin{array}{l}\text { The locations of 216-S-8 trench and well 299-W22-39 as shown in Figure 1.2 (PNNL-11810) } \\
\text { are consistent with Hanford Site Atlas (see maps 85, 93, and 103, BHI-01119, Rev. 1, May } \\
\text { 1998). }\end{array}$ & \\
\hline 32 & Comment noted. & \\
\hline 33 & Comment incorporated (see disposition of comment 2). & $\begin{array}{l}\text { Sections } 1.1\left(5^{\text {th }} \text { paragraph }\right), 1.2\left(2^{\text {nd }}\right. \\
\text { bullet }), 3.0 \text { and } 4.0\end{array}$ \\
\hline 34 & $\begin{array}{l}\text { Comment noted. The focus (of PNNL-11810) was on new information acquired in connection } \\
\text { with the first determination assessment. }\end{array}$ & \\
\hline 35 & Comment incorporated (see disposition of comment 2). & $\begin{array}{l}\text { Sections } 1.1\left(5^{\text {th }} \text { paragraph }\right), 1.2\left(2^{\text {nd }}\right. \\
\text { bullet), } 3.0 \text { and } 4.0\end{array}$ \\
\hline$\cdot 36$ & Comment incorporated (see disposition of comment 2). & $\begin{array}{l}\text { Sections } 1.1\left(5^{\text {th }} \text { paragraph }\right) \text { and } 1.2\left(2^{\text {nd }}\right. \\
\text { bullet })\end{array}$ \\
\hline 37 & Comment noted (see disposition of comment 3 ). & PNNL-12114 (entire report) \\
\hline 38 & Comment incorporated (see disposition of comment 2). & $\begin{array}{l}\text { Sections } 1.1\left(5^{\text {th }} \text { paragraph), } 1.2\left(2^{\text {nd }}\right.\right. \\
\text { bullet), } 3.0 \text { and } 4.0\end{array}$ \\
\hline 39 & CWR stands for cladding removal waste from REDOX. & \\
\hline 40 & Comment incorporated. & Section 2.2.3 (leak volumes) \\
\hline 41 & Comment incorporated. & Section 2.3 \\
\hline 42 & Comment noted. & \\
\hline
\end{tabular}


Table B.2. (contd)

\begin{tabular}{|c|c|c|}
\hline $\begin{array}{l}\text { Comment } \\
\text { Number }\end{array}$ & Disposition & Reference in PNNL-12114 \\
\hline 43 & $\begin{array}{l}\text { Comment noted. The adjective "potential" was out of place. The phrase should have read: } \\
\text { ".... the tanks designated as leakers (Figure 1.2) are the largest potential sources of } \\
\text { groundwater contamination. It has not be demonstrated if tank leaks or spills are the cause. }\end{array}$ & $\cdots$ \\
\hline 44 & $\begin{array}{l}\text { Comment noted. A more comprehensive evaluation and summary of relevant tank farm } \\
\text { vadose zone radionuclide and in situ spectral gamma log data, stratigraphy, source descrip- } \\
\text { tions, geochemistry etc. is required for development of a consensus subsurface physical } \\
\text { description or model is part of the RCRA Facility Investigation work plan development for } \\
\text { Waste Management Area S-SX and vicinity [reference: Tri-Party Agreement change number } \\
\text { M-45-98-03). }\end{array}$ & . \\
\hline 45 & Comment noted. & \\
\hline 46 & $\begin{array}{l}\text { Comment incorporated. The reaction product issue is also a fundamental question for the } \\
\text { RCRA Facility Investigation work plan development for S-SX tank farm. }\end{array}$ & Section 2.3 ( $4^{\text {th }}$ paragraph) \\
\hline 47 & $\begin{array}{l}\text { Comment incorporated. Also related to comment } 46 \text {. While it may be an "established fact" } \\
\text { that caustic solutions dissolve aluminum and silica, the reactions that may have occurred under } \\
\text { extreme conditions (several hundred degrees Fahrenheit) and with a mixture of basaltic and } \\
\text { granitic silicate rock fragments or sand grains, may not be so obvious. The effect of tempera- } \\
\text { ture and the changing chemistry as the reaction progressed is a highly complex thermodyna- } \\
\text { mic problem. All we know is that in a laboratory column, at room temperature, the caustic } \\
\text { reactions were able to plug the pore spaces in a leaching column filled with Hanford sandy } \\
\text { soil. Additional laboratory tests under conditions more closely related to emplacement con- } \\
\text { ditions at the time of early leaks (i.e., high temperature leaching) would be needed to better } \\
\text { understand this hypothesized phenomenon. }\end{array}$ & Section 2.3 ( $4^{\text {th }}$ paragraph) \\
\hline 48 & $\begin{array}{l}\text { Comment noted. The term "broad wetting front" in the context of the referenced discussion } \\
\text { was meant to convey the idea depicted in the associated figure (Figure 2.1, PNNL-11810); i.e., } \\
\text { a wetted area that spreads laterally as it moves downward and with the dimensions of a per- } \\
\text { haps } 2 \text { tank diameters ( } 40 \text { to } 50 \mathrm{~m} \text { ). This is consistent with the modeling results presented by } \\
\text { Ward et al. 1997. The intent of the question is also the subject of the RCRA Facility } \\
\text { Investigation effort noted in the response to comment } 44 \text { above. }\end{array}$ & $\therefore$ \\
\hline 49 & $\begin{array}{l}\text { Comment incorporated. A qualifier was added to the conceptualization discussion in the plan. } \\
\text { Also, this subject is more related to the new Tri-Party Agreement milestone for development } \\
\text { of the RCRA Facility Investigation work plan for S-SX tank farm. }\end{array}$ & Section 2.3 ( $2^{\text {nd }}$ and $3^{\text {rd }}$ paragraphs) \\
\hline
\end{tabular}


Table B.2. (contd)

\begin{tabular}{|c|c|c|}
\hline $\begin{array}{l}\text { Comment } \\
\text { Number }\end{array}$ & Disposition & Reference in PNNL-12114 \\
\hline 50 & Comment incorporated (see disposition of comment 4). & Section 1.1 ( $3^{\text {rd }}$ paragraph) \\
\hline 51 & Comment incorporated. & Section 2.3.1 \\
\hline 52 & Comment incorporated. & Section 2.3.2 \\
\hline 53 & Comment incorporated. & Section 2.2.1 (1 $1^{\text {st }}$ paragraph) \\
\hline 54 & Comment incorporated. & Section 1.1 ( $4^{\text {th }}$ paragraph) \\
\hline 55 & Comment incorporated. & Section 2.2.3 \\
\hline 56 & Comment incorporated. & $\begin{array}{l}\text { Section } 2.2 .3 \text { (tritium/technetium-99 } \\
\text { observations) }\end{array}$ \\
\hline 57 & Comment incorporated (see disposition of comment 53). & Section 2.2.1 ( $1^{\text {st }}$ paragraph) \\
\hline 58 & $\begin{array}{l}\text { Disagree. Well 299-W22-44 is downgradient of } 241-\mathrm{S}-152 \text { diversion box located inside of the } \\
\text { northern portion of the } 241-\mathrm{S} \text { tank farm. As the groundwater flow direction becomes more } \\
\text { easterly, well } 299-\text { W } 22-44 \text { will be downgradient from the northern set of single-shell tanks in } \\
\mathrm{S} \text { tank farm. Also, spills occurred in the transfer lines to SY-102, thus this well is highly } \\
\text { relevant to the overall purpose of monitoring and investigation of the nature and extent of } \\
\text { contamination from the waste management area and vicinity waste systems and spills. } \\
\text { Results from proposed task on modeling and directional mapping (Appendix A.1, PNNL- } \\
12114 \text { ) will address Ecology concerns concerning well detection efficiency in relation to } \\
\text { possible source areas. However, it is impossible to state which wells will be likely to intercept } \\
\text { a potential leak from } \\
\text { a given tank or other source. The overall detection efficiency is estimated using MEMO, a } \\
\text { computer model developed to assess the probability of detection and is described in the } \\
\text { Hanford Site Part B permit application, Section 5, "Groundwater Monitoring." This model } \\
\text { assumes every unit area (e.g., } 20 \mathrm{~m}^{2} \text { within Waste Management Area S-SX) is a potential } \\
\text { source. The MEMO results and RCRA network well locations used in the original monitoring } \\
\text { plan are included in this addendum (Figure B.1). }\end{array}$ & $\begin{array}{l}\text { Appendix A.1 (sections A.1.1.3 and } \\
\text { A.1.1.7) }\end{array}$ \\
\hline 59 & Comment incorporated (see disposition of comment 2 ). & $\begin{array}{l}\text { Summary and Section } 1.1\left(5^{\text {th }}\right. \\
\text { paragraph) }\end{array}$ \\
\hline 60 & Comment noted. & \\
\hline
\end{tabular}


Table B.2. (contd)

\begin{tabular}{|c|c|c|}
\hline $\begin{array}{l}\text { Comment } \\
\text { Number }\end{array}$ & Disposition & Reference in PNNL-12114 \\
\hline 61 & Comment incorporated (see disposition of comment 53). & Section 2.2.1 ( $1^{\text {st }}$ paragraph) \\
\hline 62 & Comment incorporated. & Section 2.2.1 ( $1^{\text {st }}$ paragraph $)$ \\
\hline 63 & Comment incorporated (see disposition of comment 53). & Section 2.2.1 ( $1^{\text {st }}$ paragraph) \\
\hline 64 & Comment incorporated (see disposition of comment 40). & Section 2.2.3 (leak volumes) \\
\hline 65 & $\begin{array}{l}\text { Footnote in Appendix B of PNNL-1 } 1810 \text { provided the requested information (i.e., all results } \\
\text { flagged with } \mathrm{a}^{*} \text { indicate bailed sample). }\end{array}$ & \\
\hline 66 & $\begin{array}{l}\text { Tritium concentrations in well } 299-\mathrm{W} 23-1 \text { range from non-detect to } 2,600 \mathrm{pCi} / \mathrm{L} \text {. No } \\
\text { discernable trend is observed. In addition, tritium has exhibited abruptly increasing and } \\
\text { decreasing trends in upgradient well } 299-\mathrm{W} 23-14 \text {. Tritium has been increasing in several } \\
\text { downgradient wells at the SX tank farm (wells } 299-\mathrm{W} 22-45,299-\mathrm{W} 22-39,299-\mathrm{W} 23-3 \text {, and } \\
299-\mathrm{W} 23-2 \text { ) since September } 1994 \text {. }\end{array}$ & $\begin{array}{l}\text { Section } 2.2 .3 \text { (tritium/technetium-99 } \\
\text { observations) }\end{array}$ \\
\hline 67 & Comment incorporated (see disposition of comment 53). & Section 2.2.1 ( $1^{\text {st }}$ paragraph $)$ \\
\hline 68 & $\begin{array}{l}\text { The point of Section } 3.2 \text { is stated in the last sentence of the last paragraph (PNNL-11810). } \\
\text { That is, the major chemical components of tank liquor are sodium and nitrate. One might } \\
\text { suppose that both sodium and nitrate should be elevated in groundwater if the source of the } \\
\text { observed increase in specific conductance and nitrate was due to a tank waste source. But, as } \\
\text { discussed in Section } 3.2 \text {, calcium and magnesium (in the downgradient groundwater with } \\
\text { elevated nitrate) are the dominant cations, not sodium. The explanation provided is that the } \\
\text { sodium could have exchanged for calcium and magnesium in the soil column, much like } \\
\text { regenerating a water softener with sodium chloride. Given this possible mechanism, } \\
\text { groundwater contamination from a tank waste source need not necessarily be dominated by } \\
\text { sodium even though the sodium nitrate is the primary chemical component of tank liquor. }\end{array}$ & $c$ \\
\hline 69 & $\begin{array}{l}\text { Comment noted. Tritium concentrations in well } 299-W 23-1 \text { range from non-detect to } 2,600 \mathrm{pCi} / \mathrm{L} \text {. } \\
\text { No discernable trend is observed. Tritium has not been detected in well } 299-\mathrm{W} 23-13 \text {. This is } \\
\text { consistent with the absence of a major upgradient source of tritium in this area. }\end{array}$ & $\begin{array}{l}\text { Section } 2.2 .3 \text { (discussion of recent } \\
\text { tritium and technetium-99 in 299-W23- } \\
1 \text { added) }\end{array}$ \\
\hline 70 & $\begin{array}{l}\text { See disposition of comment } 69 \text { concerning tritium concentrations in wells } 299-\text { W } 23-1 \text { and } \\
\text { 299-W23-13. See disposition of comment } 66 \text { concerning trends observed in other wells. } \\
\text { Also, the changing tritium concentration in the these wells is discussed in the } 1998 \text { annual } \\
\text { Hanford Site groundwater report (PNNL-12086). }\end{array}$ & $\begin{array}{l}\text { Section } 2.2 .3 \text { (tritium/technetium-99 } \\
\text { observations) }\end{array}$ \\
\hline
\end{tabular}


Table B.2. (contd)

\begin{tabular}{|c|c|c|}
\hline $\begin{array}{l}\text { Comment } \\
\text { Number }\end{array}$ & Disposition & Reference in PNNL-12114 \\
\hline 71 & $\begin{array}{l}\text { Contour maps for tritium and technetium-99 for fiscal year } 1995 \text { and fiscal year } 1996 \text { were } \\
\text { presented in Figure } 3.11 \text { and Figure 3.4, respectively, of the subject report (PNNL-11810). }\end{array}$ & \\
\hline 72 & $\begin{array}{l}\text { The two different areas are clearly identified by the contour plots for tritium and technetium- } \\
99 \text { in Figure } 3.4 \text { (PNNL-11810). The source areas under consideration are those in the } \\
\text { immediate vicinity of Waste Management Area S-SX. The point is simply that the tritium and } \\
\text { technetium- } 99 \text { plumes do not seem to overlap, indicating different source areas. Also see } \\
\text { disposition of comments } 66 \text { and } 70 \text {. }\end{array}$ & $\begin{array}{l}\text { Section } 2.2 .3 \text { (tritium/technetium-99 } \\
\text { observations }\end{array}$ \\
\hline 73 & Comment noted. & \\
\hline 74 & Comment noted. & \\
\hline 75 & Comment incorporated. & Section 2.2.3 \\
\hline 76 & Comment noted. & \\
\hline 77 & $\begin{array}{l}\text { Comment noted. Enhanced discussion of tritium/technetium- } 99 \text { ratio is provided in PNNL- } \\
12114 .\end{array}$ & $\begin{array}{l}\text { Section } 2.2 .3 \text { (tritium/technetium-99 } \\
\text { observations }\end{array}$ \\
\hline 78 & Comment noted. & \\
\hline 79 & We have checked our data file. Well number $299-$ W22-10 is correctly indicated on Figure 3.5 & \\
\hline 80 & $\begin{array}{l}\text { Comment incorporated. Enhanced discussion of tritium/technetium-99 ratio for well 299- } \\
\text { W23-1 is provided in PNNL-12114. }\end{array}$ & $\begin{array}{l}\text { Section } 2.2 .3 \text { (tritium/technetium-99 } \\
\text { observations) }\end{array}$ \\
\hline 81 & We are unable to locate technetium-99 or tritium data for well $299-$ W23-5. & \\
\hline 82 & $\begin{array}{l}\text { Comment incorporated. Hydrographs of well } 299-\text { W23-3 and } 299-\text { W23-4 are presented in } \\
\text { Figure 5.2 (PNNL-12114). Water level data and the rate of decline (ft/yr) near Waste } \\
\text { Management Area S-SX are provided in Tables B.1 and B.2 (Appendix, PNNL12114). } \\
\text { Additional hydrographs for the RCRA and non-RCRA wells are attached (Figures B.2, B.3, } \\
\text { B.4, B.5, and B.6). }\end{array}$ & $\begin{array}{l}\text { Figure } 5.2 \text { and Appendix B (Tables B.1 } \\
\text { and B.2) }\end{array}$ \\
\hline 83 & Comment incorporated (see disposition of comment 82). & Appendix B (Table B.2) \\
\hline
\end{tabular}


Table B.2. (contd)

\begin{tabular}{|c|c|c|}
\hline $\begin{array}{l}\text { Comment } \\
\text { Number }\end{array}$ & Disposition & Reference in PNNL-12114 \\
\hline 84 & $\begin{array}{l}\text { Reported tritium value (Table 3.1, PNNL-11810) is the measured result } 65,200 \mathrm{pCi} / \mathrm{L} \pm 2 \\
\text { sigma counting error ( } 4,940 \mathrm{pCi} / \mathrm{L} \text { ) (counting error is about } 7.6 \% \text { ) when pump intake was set } \\
\text { at } 1 \mathrm{ft} \text { below the static water level in well } 299-\text { W22-46. Table } 3.1 \text { (PNNL-11810) indicates } \\
\text { there is very little difference in concentrations of constituents from the very top of the aquifer } \\
\text { as compared to the normal depth. Depth distribution is also a major objective for the } \\
\text { continued assessment (PNNL-12114) and RCRA Facility Investigation. }\end{array}$ & Section 6.3 and Appendix A.1 (A.1.1.2) \\
\hline 85 & $\begin{array}{l}\text { The primary point made in Section } 3.5 .2 \text { was that the cesium- } 137 \text { and strontium- } 90 \text { must be } \\
\text { migrating much more slowly through the vadose zone (and/or aquifer) than is technetium-99; } \\
\text { i.e., where high technetium- } 99 \text { concentrations are observed in groundwater there has been } \\
\text { undetected cesium-137 and strontium-90. See Expanded Disposition of Comment } 85 \text { for } \\
\text { detailed explanation. }\end{array}$ & \\
\hline 86 & $\begin{array}{l}\text { The iodine-129 result referred to in HEIS (sample number B0K8D9) was included in Table } 3.1 \\
\text { (PNNL-11810) and was a non-detect as stated in the report [see footnote (d)]. The data not } \\
\text { available ("NA") was for the shallow sample obtained by raising the pump intake to near the } \\
\text { surface. The table or its equivalent will be updated in future assessment reports. }\end{array}$ & ' \\
\hline 87 & $\begin{array}{l}\text { As stated in Section } 3.5\left(1^{\text {st }} \text { paragraph, } 1^{\text {st }} \text { sentence) the occurrence of technetium-99 in well }\right. \\
299-W 22-46 \text { offered an opportunity to examine concentration variations with depth. The } \\
\text { experiment was conducted on May } 8,1997 \text { using two sampling depths: shallow (where pump } \\
\text { intake was set at } 1 \mathrm{ft} \text { below the static water level in the well) and normal sampling depth } \\
\text { (where pump intake was set at } 5 \text { to } 7 \mathrm{ft} \text { below the static water level in the well). Results of this } \\
\text { experiment were presented in Table } 3.1 \text { (PNNL-11810). The tritium value measured on } \\
\text { May 23, } 1997 \text { was from sampling conducted at normal depth. }\end{array}$ & 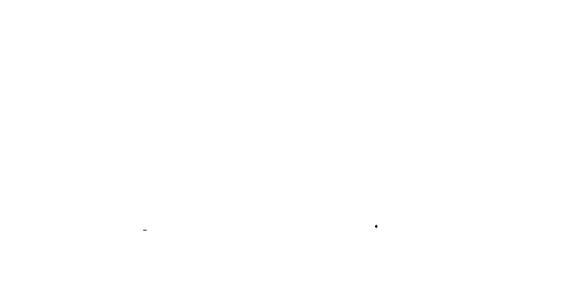 \\
\hline
\end{tabular}


Table B.2. (contd)

\begin{tabular}{|c|c|c|}
\hline $\begin{array}{l}\text { Comment } \\
\text { Number }\end{array}$ & Disposition & Reference in PNNL-12114 \\
\hline 88 & $\begin{array}{l}\text { The alternative possibility discussed in Section } 3.5 \text { is an intermediate situation that, if it were } \\
\text { true, could explain why cesium-137 and strontium-90 are not observed in downgradient } \\
\text { groundwater along with the elevated technetium- } 99 \text {. That is, if normally non-mobile con- } \\
\text { taminants are mobile in a high salt medium they could spread through the vadose zone until } \\
\text { the salt matrix and contaminants reach the water table. At that point, dilution of the high salt } \\
\text { matrix would result in sorption and retardation cesium-137. The key issue from a risk or } \\
\text { protection of human health perspective is that even if the high salt matrix reaches ground- } \\
\text { water, dilution will eventually result in a lowering of the ionic strength of the contaminant } \\
\text { plume and sorption of the cesium-137 and strontium-90 would then occur. However, the } \\
\text { absence of any strong indication of significant or detectable cesium-137 in groundwater } \\
\text { monitoring wells within and adjacent to Waste Management Area S-SX suggests the hypo- } \\
\text { thetical scenario discussed above has not occurred, or at least not yet anyway. Confirmation } \\
\text { of the latter must be made by direct observation (collection of vadose zone samples in key } \\
\text { areas). These are fundamental considerations that need to be addressed in connection with the } \\
\text { RFI/CMS work plan for Tri-Party Agreement milestone M-45-52. }\end{array}$ & Beyond scope \\
\hline 89 & $\begin{array}{l}\text { Technetium- } 99 \text { concentrations are difficult to capture as an actual plume. The occurrences are } \\
\text { transient in nature and therefore are not really amenable to contouring as in a case where a } \\
\text { continuous release from a crib has occurred (i.e., tritium). A tritium (1998 averages) and water } \\
\text { table elevation (June 1998) overlay are attached (Figure B.7). Concerning the apparent } \\
\text { discrepancy in groundwater flow direction based on technetium-99 plumes, it must be recog- } \\
\text { nized that groundwater will not always flow in the same direction as predicted based on the } \\
\text { hydraulic gradient. The fact that contaminant plume flow direction may differ from predicted } \\
\text { or from the general trend in tritium movement may be explainable by the differential- } \\
\text { cementing hypothesis (preferential flow through the aquifer). } \\
\text { The hydraulic data need to be updated due to the declining water levels. Slug tests are planned } \\
\text { for } 1999 \text { in existing wells that still have adequate water and in new wells planned for } 1999 \text {. } \\
\text { After that data is available, a meaningful hydraulic conductivity map revision can be prepared } \\
\text { (see Expanded Disposition of Comment } 89 \text { for detailed explanation). }\end{array}$ & Appendix A.1 (A.1.1.2) \\
\hline
\end{tabular}


Table B.2. (contd)

\begin{tabular}{|c|c|c|}
\hline $\begin{array}{l}\text { Comment } \\
\text { Number }\end{array}$ & Disposition & Reference in PNNL-12114 \\
\hline 90 & $\begin{array}{l}\text { Re-evaluation of hydraulic conductivities (review of past results as well as re-runs in selected } \\
\text { monitoring wells) is a task included in the draft assessment plan (PNNL-12114). New wells } \\
\text { planned for FY99 will also yield new slug test results (hydraulic conductivity) that can be used } \\
\text { to update the hydraulic conductivity map for this waste management area. Because conditions } \\
\text { may have changed because the water table has dropped since 1991, there would be little value } \\
\text { in updating Figure } 3.8 \text { with old data (e.g., for some new wells tested in 1992). }\end{array}$ & Appendix A.1 (A.1.1.2) \\
\hline 91 & $\begin{array}{l}\text { The gravel layers referred to in Section 3.7.2 (PNNL-11810) are the two layers just beneath } \\
\text { the tanks, not the gravel at the water table. The case described in Figure } 3.9 \text { (PNNL-11810) } \\
\text { illustrates a gravel layer in contact with the tanks and overlying sand. The disturbed or } \\
\text { backfill material would also tend to conduct water more readily down to the gravel layer and } \\
\text { then spread at the sand gravel contact. Thus water that infiltrates on the east side of S tank } \\
\text { farm might come into contact with waste beneath the tanks along the gravel-sand boundary. } \\
\text { The comment statement that there is no evidence of perched water in the } 200 \text { Areas is } \\
\text { incorrect. See Expanded Disposition of Comment } 91 \text { for detailed explanation. }\end{array}$ & \\
\hline 92 & $\begin{array}{l}\text { Results for borehole } 41-09-39 \text { were sketchy at the time the groundwater assessment report } \\
\text { (PNNL-11810) was prepared. The stated footage of } 130 \mathrm{ft} \text { in Section } 3.7 .1 \text { should have been } \\
1135 \mathrm{ft} \text {; i.e., concentrations of cesium-137 (pCi/g) observed in core samples below } 135 \mathrm{ft} \text { were } \\
1,000 \text { to } 10,000 \text { times lower than the maxima between } 60 \text { to } 85 \mathrm{ft} \text { below ground surface. The } \\
\text { reference to groundwater sampling from borehole } 41-09-39 \text { that increased the likelihood of } \\
\text { detecting breakthrough from the vadose zone, refers to the fact that a large volume of water } \\
\text { was removed thereby extending the zone of influence around the well to a larger area than } \\
\text { interrogated by just the core samples. See Expanded Disposition of Comment } 92 \text { for detailed } \\
\text { explanation. }\end{array}$ & Appendix A.1 (A.1.1.2) \\
\hline 93 & $\begin{array}{l}\text { Comment noted and incorporated in part (see dispositions of comments 12,62, and Expanded } \\
\text { Disposition of Comment 93). The samples collected from borehole } 41-09-39 \text { were both } \\
\text { filtered and unfiltered. }\end{array}$ & Appendix A.1 (A.1.1.7) \\
\hline
\end{tabular}


Table B.2. (contd)

\begin{tabular}{|c|c|c|}
\hline $\begin{array}{l}\text { Comment } \\
\text { Number }\end{array}$ & Disposition & Reference in PNNL-12114 \\
\hline 94 & $\begin{array}{l}\text { The } 0.1 \mathrm{pCi} / \mathrm{g} \text { contour was not used in the cross sections (Figures } 3.9 \text { and } 3.10 \text {, PNNL-11810) } \\
\text { because there was doubt about the validity of measurements at this level. In other words, the } \\
\text { actual detection limit when allowance is made for widely distributed particulate contamination } \\
\text { around the tank farms is most likely higher than } 0.1 \mathrm{pCi} / \mathrm{g} \text { (regional fallout cesium-137 in soil } \\
\text { is at about this level). The problem with the low ( } 0.1 \mathrm{pCi} / \mathrm{g} \text { ) level became evident by compar- } \\
\text { ing the laboratory analytical results with the spectral gamma log results for borehole } 41-09-39 \\
\text { (Myers et al } 1998 \text { ). In addition, since mid-1998, the } 0.1 \mathrm{pCi} / \mathrm{g} \text { contour has not been used in the } \\
\text { MACTEC tank farm reports. The } 0.1 \mathrm{pCi} / \mathrm{g} \text { level is most likely an artifact. Additional work is } \\
\text { needed with shape factor analysis to assess the validity of all the borehole results at the lower } \\
\text { concentration levels (Expert Panel closeout report). The issue is whether the low-level con- } \\
\text { tamination determined by spectral gamma logging of old vadose boreholes is actually distri- } \\
\text { buted in the formation or is a borehole related effect due to drag down. }\end{array}$ & Section 5.3.3 \\
\hline 95 & $\begin{array}{l}\text { See disposition of comment } 91 \text {. Also, it should be noted that lateral gamma logging indicated } \\
\text { contamination beneath tanks SX } 108 \text { and } 109 \text {. Elsewhere question marks are included in the } \\
\text { figure indicating uncertainty about either lateral or vertical movement. }\end{array}$ & \\
\hline 96 & $\begin{array}{l}\text { The status of the results for borehole } 41-09-39 \text { was uncertain at the time Figure } 3.10 \text { was } \\
\text { prepared. Also, subsequent shape factor analysis suggests the cesium-137 below } 135 \mathrm{ft} \text { was } \\
\text { drag down. Thus no major change in the depth distribution of the } 10 \mathrm{pCi} / \mathrm{g} \text { contour at the } \\
\text { borehole } 41-09-39 \text { location is deemed necessary or appropriate at this time. }\end{array}$ & \\
\hline 97 & $\begin{array}{l}\text { The uncertainty in depiction of contaminant distribution in relation to stratigraphy near tank S- } \\
104 \text { is clearly indicated with several question marks in the diagram. The figure is one inter- } \\
\text { pretation and is subject to change as more information becomes available. Dr. Weiringa (SSX } \\
\text { Expert Panel) noted that he could explain the depicted correlation the way it is drawn. This } \\
\text { does not prove the case, but indicates it is reasonable. The significance of the depiction is that } \\
\text { stratigraphy can interact with waste and waste mobilizing driving forces in this area and that } \\
\text { every effort should be made to prevent conditions conducive to further movement of con- } \\
\text { taminants through the vadose zone to groundwater. This is the basis for one of the near term } \\
\text { corrective measures as indicated in Tri-Party Agreement milestone M-45-98-03 and associated } \\
\text { milestone M-45-56-TO1. }\end{array}$ & \\
\hline
\end{tabular}


Table B.2. (contd)

\begin{tabular}{|c|c|c|}
\hline $\begin{array}{l}\text { Comment } \\
\text { Number }\end{array}$ & Disposition & Reference in PNNL-12114 \\
\hline 101 & $\begin{array}{l}\text { The Kd values used are conservative (low) for purposes of making the point that the distri- } \\
\text { bution of cesium and strontium would not be very widespread even with a Kd of } 10 \text {. A higher } \\
\text { Kd is probably more likely than not. The intent was not to make the most accurate prediction } \\
\text { possible but to simply illustrate a hypothetical case. That is, with a Kd in the lower range of } \\
\text { what has been observed for strontium and cesium, combined with the relatively slow ground- } \\
\text { water flow rate, there would be very limited lateral dispersion in the aquifer. A range of } \\
\text { predictions could be made using the various values summarized by Ames and Serne (1991), } \\
\text { but that was beyond the scope and purpose of the discussion. }\end{array}$ & Beyond scope \\
\hline 102 & $\begin{array}{l}\text { Disagree (see Expanded Disposition of Comment } 102 \text { for details). The discussion in Sec- } \\
\text { tion } 3.8 \text { was focused on the primary constituents of concern that had been identified. } \\
\text { Aluminum was identified in the conceptual model discussion as a potential constituent of } \\
\text { concern and was also discussed for the period of assessment in Appendix B (PNNL-11810). } \\
\text { The statement that the concentrations were near detection was based on the filtered results. } \\
\text { The validity of the two high values cited by Ecology is questionable. } \\
\text { Concerning the carbon tetrachloride, it is acknowledged that this constituent is present in some } \\
\text { of the S-SX wells. It is a ubiquitous groundwater contaminant in the } 200 \text { West Area due to } \\
\text { past practice discharges from the Plutonium Finishing Plant and related facilities. The appear- } \\
\text { ance of carbon tetrachloride in the headspace of some of the S-SX tanks, however, is surpris- } \\
\text { ing. It is difficult to see how it could survive in boiling tanks even if it were routed to this tank } \\
\text { farm. Nevertheless, volatile organic analysis will be added to the monitoring network list to } \\
\text { better delineate its distribution in the vicinity of Waste Management Area S-SX. } \\
\text { Nitrate was discussed in the main body of the report. Fluoride was discussed in the appendix. } \\
\text { All constituents are included for the period of the assessment. The upgradient and down- } \\
\text { gradient statistical comparison applies only during the detection phase of monitoring at this } \\
\text { regulated unit. The significance of potassium and fluoride is not clear. The only unusual } \\
\text { occurrence for potassium involved a high value ( } 950,000 \mu \mathrm{g} / \mathrm{L} \text { ) that is clearly a data entry } \\
\text { problem. Fluoride ranged from } 250 \text { to } 800 \mu g / L \text { in the monitoring network, weil below the } \\
\text { drinking water standard. }\end{array}$ & Appendix A.1 (A.1.1.7) \\
\hline 103 & Comment incorporated (see disposition of comment 2). & $\begin{array}{l}\text { Summary and Sections } 1.1 \text { ( } 5^{\text {th }} \text { para- } \\
\text { graph), } 1.2 \text { ( } 2^{\text {nd }} \text { bullet), } 3.0 \text { and } 4.0\end{array}$ \\
\hline
\end{tabular}


Table B.2. (contd)

\begin{tabular}{|c|c|c|}
\hline $\begin{array}{l}\text { Comment } \\
\text { Number }\end{array}$ & Disposition & Reference in PNNL-12114 \\
\hline 98 & $\begin{array}{l}\text { Infiltration effects on non-vegetated, gravel covered surfaces and the tank dome effect are } \\
\text { discussed in Ward et al 1997. The referenced report (preliminary modeling) was a task iden- } \\
\text { tified in the original assessment plan for S-SX (Caggiano 1996) and by reference was part of } \\
\text { the assessment. Also, this whole subject will be revisited for the S-SX RCRA Facility } \\
\text { Investigation work plan and revised conceptual model of subsurface conditions beneath Waste } \\
\text { Management Area S-SX (described in Tri-Party Agreement milestone M-45-98-03). }\end{array}$ & Beyond scope \\
\hline 99 & $\begin{array}{l}\text { The variation in moisture contents with depth in adjacent wells } 299-\text { W23-14 and 299-W22-39 } \\
\text { is correlated in part with sediment texture. (This was one of the purposes of the correlative } \\
\text { stratigraphic cross sections in Appendix A of the assessment report, PNNL-11810). As indi- } \\
\text { cated in the Appendix A (PNNL-11810), where sediments are fine grained, moisture content is } \\
\text { high. It is not known if this may reflect a past history of large amounts of water from artificial } \\
\text { sources or not. The main point here was that the moisture content in borehole } 41-09-39 \text { seems } \\
\text { surprisingly low in view of the gravel surface and expected enhanced infiltration. However, } \\
\text { the one big difference between the tank farm vadose zone and that at the immediate edges is } \\
\text { the presence of heat from the tanks near borehole } 41-09-39 \text {. This is another issue that needs to } \\
\text { be included in the revised conceptualization of subsurface physical conditions for the RCRA } \\
\text { Facility Investigation work plan. }\end{array}$ & Beyond scope \\
\hline 100 & $\begin{array}{l}\text { Borehole } 41-09-39 \text { is not the only borehole that suggests a downward "finger" of activity in } \\
\text { the vicinity of tanks SX-108/SX-109. All the borehole data for the wells shown were used. } \\
\text { The SX tank farm report includes a 3-D display of cesium-137 distribution (Figure 32, page } \\
\text { 78-D, DOE/DD/12584-268, GJPO-HAN-4) which also shows this finger that was prepared } \\
\text { before } \\
41-09-39 \text { was installed. Likewise, MACTEC-Meir has recently prepared 3-D displays using } \\
\text { only the older gross gamma log data. This also indicates a downward finger in the vicinity } \\
\text { of 41-09-39. However, we agree that it is not known at this time whether or not downward } \\
\text { transport occurs via vertical features (such as clastic dikes) or by more widely distributed } \\
\text { transport through the formation. This is a primary issue that must be addressed in the RCRA } \\
\text { Facility Investigation work plan. }\end{array}$ & Beyond scope \\
\hline
\end{tabular}


Table B.2. (contd)

\begin{tabular}{|c|c|c|}
\hline $\begin{array}{l}\text { Comment } \\
\text { Number }\end{array}$ & Disposition & Reference in PNNL-12114 \\
\hline 104 & Comment noted. & \\
\hline 105 & $\begin{array}{l}\text { Comment noted. This is also what is stated in the report. This scenario was included because } \\
\text { some individuals felt there was evidence for a north-to-south flow. But as stated in the assess- } \\
\text { ment report (Section } 4.1 .1 \text {, PNNL-11810), it is not possible to account for all the occurrences } \\
\text { in all wells with this one source scenario. }\end{array}$ & \\
\hline 106 & $\begin{array}{l}\text { Disagree. There are differences of opinion on the meaning and significance of vadose and } \\
\text { groundwater contaminant occurrences at Waste Management Area S-SX, as discussed in the } \\
\text { narrative, Expanded Disposition of Comment } 106 \text {. }\end{array}$ & Beyond scope \\
\hline 107 & Disagree (see Expanded Disposition of Comment 107). & Beyond scope \\
\hline 108 & $\begin{array}{l}\text { We acknowledge that utility line leakage over waste sites is another potential driving force at } \\
\text { various waste site locations other than tank farms (PNNL-11810). Even small continuous } \\
\text { leaks ( }<0.1 \mathrm{gpm} \text { ) are capable of transporting soluble constituents to groundwater. }\end{array}$ & \\
\hline 109 & There are no records to our knowledge concerning the volume of line loss. & \\
\hline 110 & $\begin{array}{l}\text { Comment noted. It is beyond the scope of PNNL-11810 to provide an approximation of the } \\
\text { age of the cottonwood tree and the water required for the tree to survive. Also, the upgradient } \\
\text { and downgradient statistical comparison applies only during the detection phase of monitoring } \\
\text { at this regulated unit. The assessment report (PNNL-11810) presented the findings and con- } \\
\text { clusions of the first determination as required by } 40 \text { CFR 265.93(d) [by reference of WAC } \\
173-303-400(3) \text { ]. However, as requested, indicators of possible water line leakage and speci- } \\
\text { fic conductance patterns are discussed in greater detail (see Expanded Disposition of Comment } \\
107 \text { following this table). }\end{array}$ & Beyond scope \\
\hline
\end{tabular}


Table B.2. (contd)

\begin{tabular}{|c|c|c|}
\hline $\begin{array}{l}\text { Comment } \\
\text { Number }\end{array}$ & Disposition & Reference in PNNL-12114 \\
\hline 111 & $\begin{array}{l}\text { Disagree. The upgradient and downgradient statistical comparison is appropriate only during } \\
\text { the detection phase (i.e., indicator evaluation) of monitoring at this regulated unit. The con- } \\
\text { dition described in the comment (downgradient specific conductance appears to be greater } \\
\text { than upgradient) was one criterion used to place the site in assessment. The follow-up investi- } \\
\text { gation (i.e., the first determination) was to determine what chemicals caused the increase in } \\
\text { specific conductance. The cause, as discussed in the assessment report, was due to nitrate and } \\
\text { associated major cations that, together with other indicators of tank waste (hexavalent chrom- } \\
\text { ium and technetium-99), pointed to the waste management area as the source of groundwater } \\
\text { contamination in wells } 299 \text {-W23-15 and } 299-\text { W22-46. The differences between the upgrad- } \\
\text { ient and downgradient specific conductances for Waste Management Area S and SX are } \\
\text { illustrated in Figures B.8, B.9, and B.10. As shown in these plots, specific conductance in } \\
\text { well } 299 \text {-W23-14 (upgradient well for the SX farm) remained fairly stable from October } 1991 \\
\text { to February } 1995 \text {. Subsequently it fluctuates and is currently trending upward. Similarly, } \\
\text { specific conductance in well } 299-W 23-13 \text { (upgradient well for the S farm) remained fairly } \\
\text { stable from October } 1991 \text { to February } 1995 \text {, but the concentration was higher than down } \\
\text { gradient wells } 299-W 22-45 \text { and } 299-W 22-44 \text {. Subsequently, it is trending downward. These } \\
\text { changes invalidate statistical evaluation, for the upgradient wells, which requires represen- } \\
\text { tative baseline conditions. }\end{array}$ & \\
\hline 112 & $\begin{array}{l}\text { Comment noted. All available } 1997 \text { specific conductance values (February, May, August, and } \\
\text { November 1997) for wells within or adjacent to the Waste Management Area S-SX were } \\
\text { averaged for the contours of specific conductance. Well } 299-\text { W } 23-7 \text { was sampled once in } \\
1997 \text { (August } 27,1997, \text { bailed sample) with a conductivity measurement of } 160 \mu \mathrm{S} / \mathrm{cm} \text { as } \\
\text { noted by Ecology. The major anions and cations were also depressed for this sample. Sub- } \\
\text { sequent conductivity values were also depressed. The values were } 206 \mu \mathrm{S} / \mathrm{cm} \text {, June } 29,1998 \text {; } \\
181 \mu \mathrm{S} / \mathrm{cm} \text {, September } 16,1998 ; \text { and } 182 \mu \mathrm{S} / \mathrm{cm} \text {, January } 11,1999 \text {. Thus the anomaly is not } \\
\text { an outlier. Subsequent data support the statement made on Figure } 4.3 \text { (PNNL-11810) that a } \\
\text { raw water source of local origin near this well is suspected. However, it should be noted that } \\
\text { the well can no longer be pumped and only bailed samples can be collected. }\end{array}$ & \\
\hline
\end{tabular}


Table B.2. (contd)

\begin{tabular}{|c|c|c|}
\hline $\begin{array}{l}\text { Comment } \\
\text { Number }\end{array}$ & Disposition & Reference in PNNL-12114 \\
\hline 117 & $\begin{array}{l}\text { Comment incorporated. The hypothesized movement of a source through the area could } \\
\text { account for the occurrence of the same patch of contamination in more than one well. How- } \\
\text { ever, it is also possible, as suggested, that each occurrence represents a separate source. } \\
\text { Wording was added to the appropriate plan section (PNNL-12114) indicating an alternative } \\
\text { explanation for the multiple occurrences of technetium- } 99 \text { and nitrate in the old wells inside } \\
\text { the tank farm could have each come from separate source areas. However, it is also possible } \\
\text { that single sources may have passed more than one monitoring well. This view forms the } \\
\text { basis of the hypothesized corridor of possible movement of a contaminant patch originating } \\
\text { in the S tank farm. }\end{array}$ & Section 2.3.2 ( $3^{\text {rd }}$ paragraph $)$ \\
\hline 118 & $\begin{array}{l}\text { The drinking water standard based on nitrogen }(10 \mathrm{mg} / \mathrm{L}) \text { is converted to the equivalent as } \\
\mathrm{NO}_{3} \text { using the atomic weights to first compute the mole fraction of } \mathrm{N} \text { in } \mathrm{NO}_{3} \text { as follows: } \\
\text { Mole fraction for nitrogen in nitrate }=\left[14.008 /\left(14.008+3^{*} 16\right)\right]=0.2258 \\
\text { Nitrogen standard as nitrate }=(10 \mathrm{mg} \mathrm{N} / \mathrm{L}) / 0.2259(\mathrm{~N} / \mathrm{N} 03)=44.3 \mathrm{mg} / \mathrm{L} \text { which is rounded up } \\
\text { to } 45 \mathrm{mg} / \mathrm{L} \text {. }\end{array}$ & \\
\hline 119 & $\begin{array}{l}\text { Disagree. The statement was accurate as written for conditions that existed in } 1997 \text {. How- } \\
\text { ever, since that time chromium, nitrate, and technetium- } 99 \text { have recurred in well } 299-\text { W23-1 } \\
\text { as a transient event similar to the one that occurred in } 1985-86 \text {. Also, technetium-99 and } \\
\text { nitrate have not declined as expected in well } 299-\text { W22-46, suggesting this may be a different } \\
\text { source than the source that caused the transient in well } 299-\text { W23-15. All we can do is observe } \\
\text { what happens over time and attempt to correlate the contaminant occurrences with source } \\
\text { areas and hydrologic events. We did not intend to leave the impression that the contamination } \\
\text { was going away. }\end{array}$ & \\
\hline 120 & $\begin{array}{l}\text { Disagree. The nitrate criteria of } 10 \mathrm{mg} / \mathrm{L} \text { used by reviewers applies to results reported as } \\
\text { nitrogen in nitrate (as } \mathrm{N}) \text {. However, when results are reported as nitrate }\left(\text { as } \mathrm{NO}_{3} \text { ) the criteria of }\right. \\
45 \mathrm{mg} / \mathrm{L} \text { apply (see Comment } 118 \text { disposition). Nitrate exceedances cited by Ecology are } \\
\text { incorrect because these data were reported as nitrate rather than nitrogen in nitrate. }\end{array}$ & \\
\hline 121 & See disposition of comment 12 and comment 93 . & Appendix A.1 (A.1.1.7) \\
\hline
\end{tabular}


Table B.2. (contd)

\begin{tabular}{|c|c|c|}
\hline $\begin{array}{l}\text { Comment } \\
\text { Number }\end{array}$ & Disposition & Reference in PNNL-12114 \\
\hline 113 & $\begin{array}{l}\text { An attempt was made to grout seal the older wells inside the } S \text { and } S X \text { tank farms in the mid } \\
70 \text { 's. However, the method used (Webster completion) did not use pressure grouting methods; } \\
\text { therefore, the integrity of the seal is questionable. Also, the seals installed in this manner did } \\
\text { not extend to the water table. For example, well } 299-W 23-1 \text {, located inside the } S \text { tank farm } \\
\text { near tank S-107, was grouted to } 175 \mathrm{ft} \text { below ground surface. Also, the well is perforated and } \\
\text { screened from } 180 \mathrm{ft} \text { down to } 4 \mathrm{ft} \text { below the water table (current bottom is at } 215 \mathrm{ft} \text { below } \\
\text { ground surface). Grouting performed in these older wells was injected by gravity feed and } \\
\text { may not have created a continuous seal around the casing. The six wells of this type located } \\
\text { inside the } S \text { and } S X \text { tank farms were placed on the decommissioning priority list. The double } \\
\text { casing will be shot perforated and the grout will be injected into the perforations under } \\
\text { pressure to assure that a good seal is obtained between the formation and the outer casing wall. } \\
\text { The main point is that it cannot be assumed the current seals are adequate to prevent down- } \\
\text { ward migration of fluid around the well casing. Gamma logs for this well may not be reliable } \\
\text { because of the grout and dual casing. For this reason, a spectral gamma log of the well was } \\
\text { not requested. However, this could be done for pre-decommissioning. Old gamma logs } \\
\text { (Figures B.11 and B.12) suggest near surface contamination around this well (see Expanded } \\
\text { Disposition of Comment } 113 \text { following this table). }\end{array}$ & \\
\hline 114 & $\begin{array}{l}\text { Comment noted. As requested, hydrographs for selected older wells and RCRA compliant } \\
\text { wells (Figures B.2, } 3,4,5,6 \text { ) are included in the attachment along with a discussion of pos- } \\
\text { sible implications of any hydrographic anomalies (see Expanded Disposition of Comment } 114 \\
\text { following this table). }\end{array}$ & \\
\hline 115 & Comment incorporated (see disposition of comment 2). & $\begin{array}{l}\text { Summary and Sections } 1.1\left(5^{\text {th }}\right. \\
\text { paragraph), } 1.2\left(2^{\text {nd }} \text { bullet }\right), 3.0 \text { and } 4.0\end{array}$ \\
\hline 116 & Comment incorporated (see disposition of comment 7). & Section 2.2.1 ( $1^{\text {st }}$ paragraph) \\
\hline
\end{tabular}


Table B.2. (contd)

\begin{tabular}{|c|c|c|}
\hline $\begin{array}{l}\text { Comment } \\
\text { Number }\end{array}$ & Disposition & Reference in PNNL-12114 \\
\hline 122 & $\begin{array}{l}\text { Comment noted. The sentence only reinforces the fact that more observations are needed to } \\
\text { confirm a declining trend which has not well developed. }\end{array}$ & \\
\hline 123 & $\begin{array}{l}\text { The meaning of short-term contaminant transient was provided in Section } 3.8 .1 \\
\text { (PNNL-11810). That is, the concentrations of a contaminant or constituent change fairly } \\
\text { rapidly over a } 1 \text { to } 2 \text { year period (as depicted in Figure 3.11, PNNL-11810). }\end{array}$ & \\
\hline 124 & Comment incorporated. Explanation added. & Section $2.2 .2\left(1^{\text {st }}\right.$ and $2^{\text {nd }}$ paragraph $)$ \\
\hline 125 & $\begin{array}{l}\text { Disagree. The only well that exhibited a valid positive detection (i.e., successive results above } \\
\text { the 2-sigma counting error) was well } 299-\text { W23-7. Thus the statement in the } 7^{\text {th }} \text { bullet on } \\
\text { page } 5.1 \text { of the conclusions is correct as written (see Expanded Disposition of Comment } 125 \\
\text { for details). }\end{array}$ & \\
\hline 126 & See disposition of comment 15 . & $\begin{array}{l}\text { PNNL-12114 (groundwater component } \\
\text { ) }\end{array}$ \\
\hline 127 & Comment incorporated (see disposition of comments 7 and 62). & Section 2.2.1 ( $1^{\text {st }}$ paragraph) \\
\hline 128 & Comment noted (see disposition of comment 3 ). & PNNL-12114 (entire report) \\
\hline 129 & $\begin{array}{l}\text { Section } 6 \text { simply points out the types of studies that would be included in a subsequent study. } \\
\text { Furthermore, as stated in Section } 6.1 \text { of PNNL-11810, a plan to conduct continued ground- } \\
\text { water assessment at Waste Management Area S-SX would be prepared after receipt of com- } \\
\text { ments from Ecology on the initial findings. It was clearly indicated and anticipated that } \\
\text { Ecology would have significant comments on the report that would need to be addressed in the } \\
\text { continued assessment. This addendum and documentation of the Ecology comment disposi- } \\
\text { tion is the record of that expectation. The appropriate regulatory drivers and scope will be } \\
\text { defined for the subject RFI/CMS work plan through the data quality objectives process } \\
\text { involving Ecology, the tribes, DOE and contractors. Thus the RCRA Facility Investigation } \\
\text { and related Tri-Party Agreement milestones for Waste Management Area S-SX supersede } \\
\text { what was stated in Section } 6 \text { of PNNL-11810 as well as the Ecology comments on this section. }\end{array}$ & PNNL-12114 (entire report) \\
\hline
\end{tabular}


Table B.2. (contd)

\begin{tabular}{|c|c|c|}
\hline $\begin{array}{l}\text { Comment } \\
\text { Number }\end{array}$ & Disposition & Reference in PNNL-12114 \\
\hline 130 & $\begin{array}{l}\text { Superseded by new Tri-Party Agreement milestones for RFI/CMS (See disposition of } \\
\text { comments } 3,15 \text {, and 129). }\end{array}$ & $\begin{array}{l}\text { PNNL-12114 (groundwater } \\
\text { component) }\end{array}$ \\
\hline 131 & Comment noted (see disposition of comments 3,15 , and 129). & $\begin{array}{l}\text { PNNL-12114 (groundwater } \\
\text { component) }\end{array}$ \\
\hline 132 & Comment incorporated. & Section $1.2\left(2^{\text {nd }}\right.$ bullet $)$ \\
\hline 133 & $\begin{array}{l}\text { The objectives are more appropriate for the RCRA Facility Investigation work plan. However, } \\
\text { the part that pertains to the ongoing groundwater study is incorporated. }\end{array}$ & $\begin{array}{l}\text { Section } 1.2\left(1^{\text {st }} \text { bullet) and Appendix }\right. \\
\text { A.1 (A.1.1.7) }\end{array}$ \\
\hline 134 & Comment incorporated (see disposition of comment 2). & $\begin{array}{l}\text { Summary and Sections } 1.1\left(5^{\text {th }}\right. \\
\text { paragraph), } 1.2\left(2^{\text {nd }} \text { bullet }\right), 3.0 \text { and } 4.0\end{array}$ \\
\hline 135 & Comment incorporated. & Appendix A.1 (A.1.1.7) \\
\hline 136 & Comment noted. & \\
\hline 137 & $\begin{array}{l}\text { The groundwater flow direction is slowly shifting in a more easterly direction. Thus well 299- } \\
\text { W22-44 will be downgradient from some of the } S \text { tanks. However, the well is also down- } \\
\text { gradient from other potential sources in the northern part of the waste management area. Thus } \\
\text { we recommend that it remain in the network to cover the northern most portion of the waste } \\
\text { management area. Also, there may have been a large spill in the SY farm. The well could } \\
\text { provide some coverage for that potential source. }\end{array}$ & \\
\hline 138 & Comment incorporated. Specific upgrades are provided in draft plan (PNNL-12114). & Appendix A.1 (A.1.1.4) \\
\hline
\end{tabular}


Table B.2. (contd)

\begin{tabular}{|c|c|c|}
\hline $\begin{array}{l}\text { Comment } \\
\text { Number }\end{array}$ & Disposition & Reference in PNNL-12114 \\
\hline 139 & $\begin{array}{l}\text { This section was not intended to be all-inclusive. The new plan (as well as the existing plan) } \\
\text { provides a complete list of constituents and wells. } \\
\text { Concerning the chromium issue, once again we disagree. Filtered chromium is the only reli- } \\
\text { able indicator of hexavalent chromium in the existing database. Unfiltered samples that have } \\
\text { been acidified and the chromium determined by inductively coupled plasma (ICP) analysis do } \\
\text { not yield reliable results. The correct measurement to make, in this instance, is hexavalent } \\
\text { chromium. One of the proposed data quality objectives for the groundwater assessment at } \\
\text { Waste Management Area S-SX will be to make the appropriate measurement that eliminates } \\
\text { this ambiguity. Accordingly, we propose that a hexavalent-specific method (e.g., coloromet- } \\
\text { ric) be used on unfiltered and unacidified samples directly in the field as an analytical data } \\
\text { quality objective. This should eliminate the ambiguity about filtered versus unfiltered and will } \\
\text { ensure that the appropriate chemical measurement (i.e., hexavalent chromium is the toxic form } \\
\text { of chromium) is made that is directly comparable to the standard. }\end{array}$ & Appendix A.1 (A.1.1.7) \\
\hline 140 & $\begin{array}{l}\text { The subject well provides a record of the waste migration from a major source that could be } \\
\text { confused with tank waste (i.e., technetium-99, tritium and uranium were discharged to this } \\
\text { crib). Also, with the more easterly shift in flow directions, this well could be upgradient of the } \\
\text { southern part of SX tank farm. With the existing upgradient well going dry, substitutes are } \\
\text { needed. For these reasons, we recommend inclusion of the well in the network at least until } \\
\text { replacement wells can be drilled. }\end{array}$ & \\
\hline 141 & Comment noted, descriptions are provided in PNNL-12114. & Appendix A.1 ( A.1.1.6) \\
\hline 142 & $\begin{array}{l}\text { Beyond scope. The TWRS RFI/CMS work plan will identify the type and methods for vadose } \\
\text { zone moisture and related measurements. }\end{array}$ & Beyond scope \\
\hline 143 & Beyond scope (see disposition of comment 15). & Beyond scope \\
\hline 144 & Beyond scope. Covered by new Tri-Party Agreement Milestone M-45-56-T01. & Beyond scope \\
\hline 145 & Comment incorporated. & Section 1.1 ( $3^{\text {rd }}$ paragraph) \\
\hline 146 & $\begin{array}{l}\text { Beyond scope. The Tri-Party Agreement milestone requiring an RFI/CMS work plan and } \\
\text { related investigations addresses the intent of this comment. }\end{array}$ & Beyond scope \\
\hline
\end{tabular}


The primary point made in Section 3.5.2 was that the cesium-137 and strontium-90 must be migrating much more slowly through the vadose zone (and/or aquifer) than is technetium-99. In other words, where high technetium- 99 concentrations were observed in groundwater there has been undetected cesium- 137 and strontium-90. However, if all three contaminants were essentially mobile $(\mathrm{Kd} \sim 0)$, then cesium-137 should be present at around $10,000,000 \mathrm{pCi} / \mathrm{L}$. Because this has not been observed, the cesium and strontium must still be in the vadose zone. Initial modeling (PNNL-11463) indicated that the largest leak volume (SX-109 and vicinity) could have migrated to groundwater under conditions where no precipitates form and plug the pore spaces. Given the assertion that cesium- 137 could migrate much more rapidly than previously thought, it is reasonable to ask if the groundwater results indicate whether or not migration of the main mass of tank liquor (and cesium-137) might have reached the water table. The point of the discussion was not to discover the obvious, that there were large quantities of cesium-137 in the vadose zone, but whether or not significant migration of large amounts of cesium-137 and other fission products might have spread completely through the vadose zone to the water table.

We are puzzled by the comment that a "tremendously large" amount strontium-90 data are available for tank farm vadose zone soils. While there is little doubt that strontium-90 is present in S-SX tank farm soils, it is primarily cesium- 137 data that is available in "tremendously large" amounts (spectral gamma logging data). Strontium-90, a beta emitter (no gamma emission) has not been quantified except for a limited number of core samples. The voluminous amounts of cesium- 137 data available are partially summarized in Figure 3.10 (PNNL-11810). This data indicates significant cesium-137 retention occurs in the vadose zone, most of which is within 20 to $30 \mathrm{ft}$ below the bottom of the tanks. The core sample results from borehole 41-09-39 also suggest there is little if any cesium or strontium below $\sim 140 \mathrm{ft}$, and what is there is probably drag down. The latter is consistent with the inferences based on the ratio of cesium-137 to technetium-99 in tank waste versus groundwater discussed in Section 3.5.2. Once again, the overall point of the subject discussion was that if cesium-137 migrated much deeper than "previously thought," all of the cesium might be very mobile and reach groundwater in high concentrations. This could be rationalized if the entire mass of hot, high salt waste migrated all the way to groundwater and cesium moved along with the tank liquor unrestricted by sorption or precipitation reactions. Fortunately, as discussed in the subject section, this does not appear to be the case based on the groundwater observations. However, there is still uncertainty about the maximum depth of penetration of the tank liquor and associated contaminants.

The other point of the discussion in Section 3.5.2 was that even if cesium traveled with the high salt waste all the way to groundwater, upon dilution of the waste (reduced ionic strength of the medium) in the groundwater, cesium sorption or retardation on the aquifer solids would be expected to occur. The increase in sorption (higher Kds) with decreasing ionic strength (salt concentration) has been demonstrated in laboratory radionuclide sorption studies with Hanford soils (Ames and Serne 1991, Serne et al. 1997). 


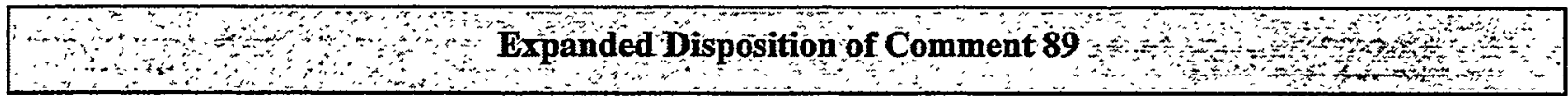

Technetium- 99 concentrations are difficult to capture as an actual plume. The occurrences are transient in nature and, therefore, are not amenable to contouring as in a case where a continuous release from a crib has occurred (e.g., tritium). Thus tritium is the best indicator for comparison with expected flow directions. The contours shown for technetium-99 are for one year. During other years they change dramatically as a patch moves through the area. An overlay of tritium 1998 averages and water table elevation (June 1998) are attached (Figure B.7). The latter suggest some deviation in flow path that could be due to the inferred anisotropy in the Ringold gravels.

Concerning the apparent discrepancy in flow direction based on technetium-99 plumes, it must be recognized that groundwater will not always flow in the predicted direction based on the hydraulic gradient. The scenarios described later are based on observed technetium-99 occurrences and patterns. The flow direction is inferred from the observations. The fact that contaminant plume flow direction may differ from that predicted or from the general trend in tritium movement may be explained by the differential-cementing hypothesis (preferential flow through the aquifer). Thus the scenarios are hypothesized to explain the observations. They are not proven fact and help to formulate new information needs. Injecting a tracer in selected wells and observing where the tracer arrives could test this hypothesis. These and related issues must be addressed in the RCRA Facility Investigation as well as in the ongoing groundwater assessment activities.

Concerning the hydraulic conductivity data/water table overlay, the hydraulic data need to be updated due to the declining water levels. Slug tests are planned for 1999 in existing wells that still have adequate water and in new wells planned for 1999. After that data is available, a meaningful hydraulic conductivity map revision can be prepared. 
The gravel layers referred to here are the two layers just beneath the tanks-not the gravel at the water table. The case described in Figure 3.9 (PNNL-11810) illustrates a gravel layer in contact with the tanks and overlying sand. The disturbed or backfill material would also tend to conduct water more readily down to the gravel layer and then spread at the sand gravel contact. Thus water that infiltrates on the east side of $S$ tank farm might come into contact with waste beneath the tanks along the gravel-sand boundary, as suggested in the comment. This concept was presented to the Expert Panel, which included the vadose zone expert Pete Weiringa. The panel raised no objection at that time (or any other time). This is another conceptualization that is more appropriate for the RCRA Facility Investigation workshop.

The comment statement that there is no evidence of perched water in the 200 Areas is incorrect. In fact, there was a perched water monitoring well at the 216-Z-20 Crib (Johnson 1993). Perched water was also identified at relatively shallow depths near Waste Management Area S-SX, just north at the 216-U14 ditch. Perched water was encountered at about 50 and $70 \mathrm{ft}$ below ground surface during drilling near this ditch. About $50 \mathrm{gpm}$ of water was discharged to the portion of the 216-U-14 ditch located at the northwest corner of $\mathrm{S}$ farm until about 1994. Also, high moisture contents (25-35 wt\%) were encountered at multiple depths between 25 and $125 \mathrm{ft}$ below ground surface on the west and east sides of SX farm during drilling of wells 216-W23-14 and 216-W22-39 during 1991-1992 (see Appendix A, PNNL-11810 or Appendix B, PNNL-12114).

There is no direct evidence that lateral water movement (preferential flow) has occurred in the gravel layer immediately beneath the $S$ tank farm. However, it was common practice to backfill drain tile networks of crib disposal structures with gravel to facilitate lateral spreading and infiltration into the sandy Hanford soils. The gravel layer that the $S$ tanks sit-on, and which are underlain by sand, represents the equivalent of a typical drain field as described above. If water were to be added from a utility line break or other water source, it seemed reasonable to expect some lateral movement through the gravel in preference to the sandy subsurface layer but not completely across the entire tank farm. Around tank S-104, as depicted in Figure 3.9, some laterally enhanced movement of water could conceivably occur to mobilize tank waste from leaking tanks. The excavated area of the tank farm itself may enhance infiltration because it is coarser textured and is no longer layered as in the adjacent undisturbed strata. In addition, the floor of the excavated pit was compacted during construction activities. This compacted layer, which included fines blown in during the time it was an open pit, could act to spread water from a large input source in the lateral direction. Also, on the east side of $S$ farm, the compacted layer would occur below the gravel (i.e., gravel overlaying a compacted layer with fines). These and related considerations are also the subject of new Tri-Party Agreement milestones that require development of a revised subsurface physical description of Waste Management Area S-SX. 
Core sample analytical results for borehole 41-09-39 were reported in HNF-2855. Results for borehole 41-09-39 were sketchy at the time when the groundwater assessment report (PNNL-11810) was prepared. The stated footage of $130 \mathrm{ft}$ in Section 3.7 .1 should have been $\sim 135 \mathrm{ft}$; i.e., concentrations of cesium-137 observed in core samples below $135 \mathrm{ft}$ were 1,000 to 10,000 times lower than the maxima between 60 to $85 \mathrm{ft}$ below ground surface. Also, there is still uncertainty as to whether or not the 1 million pCi/g of cesium-137 at $130 \mathrm{ft}$ is real or carry down from above.

The reference to groundwater sampling from borehole 41-09-39 that increased the likelihood of detecting breakthrough from the vadose zone, refers to the fact that a large volume of water was removed thereby extending the zone of influence around the well to a larger area than interrogated by the core samples. Thus, if the waste had followed a path that was missed by the borehole itself, the groundwater was drawn from a zone with a diameter of about $20 \mathrm{ft}$ or more, thereby increasing the probability of detecting contaminants from the vadose zone in that area. Perhaps even a much larger volume should be pumped to expand the zone of influence further. However, this is opposite of the effect postulated by Pete Weiringa (SX expert panel). His concern is that the well should be undisturbed and just the very top few centimeters sampled using a passive method because that may be where most of the contaminant resides that reaches the aquifer under unsaturated flow conditions. Because pumping for over a year has not disturbed the borehole, it should be possible to collect a sample from the very top of the aquifer now under undisturbed conditions. However, extended pumping could be conducted after that sampling is completed. These issues relate to the data quality objectives for decommissioning borehole 41-09-39, which are in turn a part of the overall RFI/CMS for Waste Management Area S-SX. 
The samples collected from borehole 41-09-39 were both filtered and unfiltered. Except for noted below, the chromium results (by ICP metal group analysis) were all $<3 \mu \mathrm{g} / \mathrm{L}$ for both filtered and unfiltered samples (reported in HNF-2855). The one unfiltered sample, a pumped sample collected at a shallow depth $2 \mathrm{ft}$ below static water level in the well, was $135 \mu \mathrm{g} / \mathrm{L}$. The other duplicate, unfiltered results were $195 \mu \mathrm{g} / \mathrm{L}$ and $167 \mu \mathrm{g} / \mathrm{L}$ for bottom depth (pump intake was set at $10 \mathrm{ft}$ below static water level in the well). Elevated chromium is frequently observed on a sporadic basis in unfiltered water samples from Hanford Site monitoring wells and is often associated with high turbidity, indicating the particulate nature of such occurrences. However, the standard for chromium is based on the anionic form of chromium (hexavalent) which passes easily through a membrane filter or through porous media. The particle bound form of chromium is highly unlikely to be in the hexavalent oxidation state. Thus, filtration removes the non-toxic, particle bound form of chromium (trivalent) from the hexavalent form. This issue, however, leads to a data quality objective for this important constituent relative to tank farms. Chemical speciation is needed to confirm that the filtration process is in fact accounting for all the hexavalent chromium. This data quality objective is identified in the draft assessment plan (see Appendix C, PNNL-12114). A colorometric method that responds only to hexavalent chromium will be used to analyze filtered and unfiltered samples in those wells with elevated chromium. Splits will also be analyzed by the standard ICP method. 
The discussion in Section 3.8 focused on the primary constituents of concern that had been identified. Additional discussion of all results for the period of the assessment was included in Appendix B (PNNL-11810). Aluminum was identified in the conceptual model discussion as a potential constituent of concern and was also discussed in Appendix B, as noted. The statement that the concentrations were near detection was based on the filtered results. The validity of the two high values cited by Ecology is questionable. The unfiltered aluminum result of 13,000 $\mu \mathrm{g} / \mathrm{L}$ (March 18, 1994 from well 299-W22-44, sample number B0BJY) was due to high turbidity (360 NTU). As indicated in Appendix B (footnote a, PNNL-1 1810) the other value (18,300 $\mu \mathrm{g} / \mathrm{L}$, collected on May 13, 1997 from well 299-W22-44, sample number B0KC87) was an outlier (i.e., ICP results of aluminum, calcium, chromium, iron, magnesium, manganese, potassium, and sodium were all invalid). Unfiltered samples will almost always yield higher results due to the acid leaching (samples are acidified to $\mathrm{pH} 2$ ) of the aluminosilicate (clay) particulates that appear sporadically in several of the monitoring wells at Waste Management Area S-SX (see attached data tables showing that high aluminum concentrations in unfiltered samples also had high turbidities). Because this is a well-known problem, there does not appear to be any value added by including an analysis of historical data when both filtered and unfiltered metal data were collected. This issue is also related to the chromium problem and illustrates one reason only filtered metals have been routinely collected for the RCRA program since 1994.

As noted above, this is a subject that has been covered previously for the overall RCRA program. Furthermore, the significance of particulate aluminum is not clear. Particulates larger than 0.4 micron (membrane filter size) are not likely to move through the vadose zone and aquifer. What decision would be made with this information? All that can be concluded is that when particulates (turbidity) is high, we observe high aluminum concentrations in unfiltered samples that have been acidified (The acid must be added to avoid loss of certain metals to the container by plate out or precipitation). To further address this problem, unfiltered, unacidified samples could be analyzed for comparison. Some data of this type should be available from special sampling for the transuranic/colloid studies (i.e., unfiltered, unacidified samples are analyzed by ultra low-level ICP-MS, which should also provide aluminum results as a byproduct of the analyses). The latter studies are identified in the continued assessment plan (PNNL-12114).

Concerning the carbon tetrachloride, it is acknowledged that this constituent is present in some of the S-SX wells. It is a ubiquitous groundwater contaminant in the 200 West Area due to past-practice discharges from the Plutonium Finishing Plant and related facilities. Indeed, Waste Management Area S-SX is surrounded by carbon tetrachloride from past-practice Plutonium Finishing Plant operations. Thus, it is not surprising that some carbon tetrachloride shows up in the monitoring wells. The sources and distribution of carbon tetrachloride are discussed every year in the annual Hanford Site groundwater report.

The appearance of carbon tetrachloride in the headspace of some of the S-SX tanks, however, is surprising. It is difficult to see how it could survive in boiling tanks even if it were routed to this tank farm. It would be difficult to separate background from any input from the tank farms. Nevertheless; 
volatile organic analysis will be added to the monitoring network list to better delineate carbon tetrachloride distribution in the vicinity of Waste Management Area S-SX.

Nitrate was discussed in the main body of the report and is, in fact, one of the primary constituents of concern identified for the report. Fluoride is discussed in the appendix. All constituents are included for the period of the assessment. The upgradient and downgradient statistical comparison applies only during the detection phase (i.e., indicator evaluation) of monitoring at this regulated unit. Furthermore, the specific conductance accounted for the nitrate, the primary constituent responsible for the increase in conductivity. Also, these relationships were discussed in the original assessment plan. The significance of the comment regarding potassium and fluoride is not clear. The only unusual occurrence for potassium involved a high value $(950,000 \mu \mathrm{g} / \mathrm{L}$, sample number B0KC87, May 13,1997$)$ that is clearly a data entry problem. Fluoride ranged from 250 to $800 \mu \mathrm{g} / \mathrm{L}$ in the monitoring network, well below the drinking water standard. 
The scenario depicted in Figure 4.1 of PNNL-11810 (comment 106) accounts for the observations in groundwater as well as possible sources that could account for spatial and temporal variation in groundwater contamination. What was expected was that tank waste constituents would be observed in borehole 41-09-39, and should also have appeared in well 299-W23-3 as well, if the major sources indicated in the tank-by-tank discussion in DOE (1996) were the source. To the contrary, minimal groundwater. contamination occurs at either of these key downgradient locations. However, there is evidence of very high concentrations of cesium- $137\left(>10^{8} \mathrm{pCi} / \mathrm{g}\right)$ in the soil column in the southwest corner of the SX farm near tank SX-115 (Raymond and Shdo 1966). The laterals also indicated leakage directly beneath tank SX-115. The very high cesium- 137 concentrations observed (Raymond and Shdo 1966) in the soil outside tank SX-115 are not discussed in DOE (1996) although the leak was noted and the Raymond and Shdo (1966) work was referenced. While the leak volume may have been smaller than at SX-108 and 109 , the intensity of the source, in our opinion, makes it a viable candidate for mobilization by surface water infiltration at that location. This position was presented to the Expert Panel orally, and they reviewed the document without any challenge to this interpretation. It was not included in their close out report nor expressed orally during the formal meetings when this subject was presented to them. Also, surface contamination was identified outside the fenceline and along the south end of the SX tank farm (Figure 4.1, PNNL-11810). Thus it is not clear which surface contamination the reviewer is referring to that has not been considered. It is evident that the near surface soils in the SX tank farm are contaminated. However, it is not clear how these sources would be more significant than highly intense subsurface leak sources near SX-115 and SX-108/109.

The scenario depicted in Figure 4.2 of PNNL-11810 (comment 107) attempts to account for what has actually been observed in groundwater in relation to possible sources:

1. the absence of groundwater contamination attributable to tank waste in borehole 41-09-39 (located at the major leak area identified in DOE 1996)

2. the absence of tank waste constituents in well 299-W23-3 located directly downgradient from borehole 41-09-39 and immediately upgradient of 2999-W22-46

3. the occurrence of high soil contaminants at the southwest corner of the SX tank farm where circumstantial evidence exists of water line leakage.

The other major problem is accounting for the groundwater observations in the vicinity of $\mathrm{S}$ farm. The scenario described in Figure 4.2 of PNNL-11810 is not directed at specific tanks in S farm. In fact, it was noted in the MACTEC S farm summary (DOE 1998) that surface contamination as well as the one known leaking tank are located along the east side of the $S$ farm.

We acknowledge that there may be other explanations than the one attempted in Figure 4.2. Accordingly, we have added a note to that effect in the draft plan (PNNL-12114) for continuing study of Waste Management Area S-SX. Conceptual models as used in PNNL-11810 are hypotheses (scenarios) that can hopefully be tested as one step in attempting to understand the origin and distribution of the groundwater 
contamination observed in the vicinity of Waste Management Area S-SX. Differences of opinion and interpretation of subsurface data hopefully will lead to the collection of data that will in turn result in a better understanding of the behavior of tank and related waste releases in Waste Management Area S-SX. This is one objective of the Tri-Party Agreement milestones related to development of an integrated RFI/CMS work plan for S-SX. 
Cottonwood tree. The age of the cottonwood tree is unknown. However, such trees are known to grow rapidly when fertilized and watered. We estimate the age to be on the order of $\sim 2$ years. However, this cannot be used to assign or fix a time period for when the hypothetical line leak may have started. The water source could have been present for several years and the seed for the tree deposited more recently. We do not have any means to estimate the evapotranspiration rate of the tree or to measure it directly. The tree and sagebrush in the vicinity of the tree were removed and buried onsite with a layer of gravel in order to revert this location to a non-surface contamination site. The gravel cover shields workers in the area from the surface contamination and, therefore, chaining off the area is no longer required.

Specific conductance. The upgradient and downgradient statistical comparison applies only during the detection phase (i.e., indicator evaluation) of monitoring at this regulated unit. The assessment report (PNNL-11810) presented the findings and conclusions of the first determination as required by $40 \mathrm{CFR}$ 265.93(d) [by reference of WAC 173-303-400(3)]. However, specific conductance for the monitoring wells at Waste Management Area S-SX are plotted versus time in the attached figures (Figures B.8, B.9, and B.10). The S and SX farm wells are grouped separately. There do not appear to be any discernable inflections that relate to high snow melt periods.

The background specific conductance ( $344 \mu \mathrm{S} / \mathrm{cm}$ ) referred to is natural groundwater background for the Hanford Site, not the background based on the upgradient wells. The point is that the entire area around Waste Management Area S-SX is influenced by the residual groundwater mound that was created by $U$ Pond located to the west. Thus, much lower ambient-or local background specific conductance is expected because most of the pond water was Columbia River water with an average specific conductance of about $140 \mu \mathrm{S} / \mathrm{cm}$. A 50:50 mixture of river water and natural groundwater background would yield a specific conductance of $242 \mu \mathrm{S} / \mathrm{cm}[242=0.5 * 140$ (river water average) $+0.5 * 344$ (natural groundwater background)].

Interpretation of the specific conductance data in relation to a water line leak source and a potential contamination site that could result in transport to groundwater is difficult. If no contamination is present beneath a major water line leak, the observed specific conductance in groundwater very near the source and near the top of the aquifer would be close to $140 \mu \mathrm{S} / \mathrm{cm}$ at the lowest and would be higher as it mixed with the ambient local groundwater (of about $250 \mu \mathrm{S} / \mathrm{cm}$ ) in the area. If a water line source passed through tank waste, it would entrain some amount of salt (e.g., sodium nitrate). This would increase the specific conductance to an unknown level that would then mix with the ambient groundwater beneath the hypothetical soil contamination site, resulting in elevated groundwater specific conductance above the ambient or upgradient level of about $250 \mu \mathrm{S} / \mathrm{cm}$. The occurrence of elevated specific conductance inside $S$ farm (well 200-W23-1) suggests a localized source. Other tank waste indicators have also been observed in this well (nitrate, technetium-99 and chromium). 
Highlights of specific conductance in wells upgradient and downgradient of S and SX tank farms are discussed separately in the following paragraphs.

$S$ Tank Farm. The most striking feature of the visual comparison of upgradient versus downgradient specific conductance (Figure B.9) at $S$ tank farm is the very low values for well 299-W22-44. This might be interpreted as indicative of a water line leak in that area. Another possibility is that cooling water discharged to the 216-U-14 ditch located northwest of this well may account for the low specific conductance. The latter source was terminated in 1995. Since that time, a gradual increase in specific conductance is occurring in this well. Water level changes also seem to reflect the changes in wastewater discharge practice (wastewater has been collected and routed to the Effluent Treatment Facility in 200 East since 1995). Also, specific conductance has been gradually increasing in downgradient well 299-W22-45 and is correlated with increases in chloride, nitrate, technetium-99, and tritium. At the same time, upgradient specific conductance (well 299-W23-13) has been declining and is currently at or below $200 \mu \mathrm{S} / \mathrm{cm}$. There is no apparent reason for the latter decline unless there is another source of water in that area from a water line leak.

SX Tank Farm. The specific conductance in downgradient wells at this tank farm reflect the changes in chromium, nitrate, and technetium-99 previously discussed. The close correspondence between specific conductance and mobile tank waste constituents illustrates the usefulness of this parameter as an indicator of tank waste. However, it is also noteworthy that specific conductance in upgradient well 299-W23-14 has been sharply increasing and is currently higher than the downgradient wells. This is attributed to past practice discharges of nitrate-containing wastewater to the 216-S-25 crib. As previously stated, the standard statistical comparison between upgradient and downgradient wells is not appropriate under such conditions. In these cases, trends in downgradient wells are more reliable indicators of possible new inputs of contamination from the waste management area. It also underscores the importance of maintaining upradient monitoring wells in this area to track the input from the 216-S-25 crib. Older well 299-W23-9 is ideally located for this purpose.

In summary, the specific conductance is a very useful parameter for tracking changes in the vicinity of this waste management area. It may indicate both dilution due to water line leaks (lower than ambient background, < about $250 \mu \mathrm{S} / \mathrm{cm}$ ) or may exhibit either gradual or rapidly rising values indicative of waste inputs from regulated unit and/or from upgradient sources. As an adjunct to the quarterly sampling in the network wells, at least one continuously recording in situ specific conductance probe will be used in a key well (e.g., 299-W22-46 and/or 299-W22-45). If these devices prove to be reliable, it could lead to better temporal coverage and at the same time provide real-time screening measurements that indicate unusual conditions occurring at the site. The probes will also be used to check the depth variation in specific conductance from near air-water interface to the bottom of the screened interval. 
A few old gross gamma logs were found for some of the older wells inside the S and SX tank farms. Examples are shown in Figures B.11 and B.12 for two key wells in which groundwater contamination has occurred (299-W23-1 and 299-W23-7, respectively). The logs shown were run in 1970 prior to the attempt to grout seal the upper $175 \mathrm{ft}$ of casing. Both these logs indicate near-surface contamination existed at or near the wells. A spectral gamma log was run in well 299-W23-7 in 1996 by MACTEC but did not reveal any major anomaly other than low-level cesium-137 $(<1 \mathrm{pCi} / \mathrm{g})$. However, the additional steel casing and grout between the two casings make the latter results inconclusive.

The lower sections of the gamma logs, from $10 \mathrm{ft}$ below ground surface to $180 \mathrm{ft}$ (water table elevation in 1970), are consistent with natural activity levels. The variations shown also suggest variations in response to natural stratigraphic features (sand and gravel sequences, or fine sediments). These and other deep logs on old groundwater wells could be useful in providing better definition of the deeper stratigraphy in the S and SX tank farms. Very limited stratigraphic information exists below the 75-ft and $130-\mathrm{ft}$ depths available from the vadose monitoring boreholes, all of which are located in close proximity to the single-shell tanks. The deep wells provide both better spatial coverage as well as depth information for stratigraphic correlation purposes. 
Hydrographs of the RCRA network wells are shown in Figures B.4 and B.5 for SX and S tank farms, respectively. In general they all show the same downward trend in response to the declining water table resulting from closure of $U$ pond in 1985 and termination of discharges of wastewater to various upgradient cribs and ditches in 1995. The SX wells exhibit a uniform downward trend but also indicate the gradient (from northwest to southeast) is declining along with the decrease in water table elevation.

The hydrographs for the S tank farm area exhibit the same downward trend as for SX tank farm. However, there is a small anomaly (increase over the baseline trend) in well 299-W22-45 that occurred as a transient event that peaked in June 1998. This small increase appears to be defined by more than one data point and is judged to be real. The impact of this one localized anomaly is evident in the June 1998 water table map (Figure B.7). The cause of this anomaly is unknown. No intentional input of water has occurred; however, localized losses from a water line cannot be ruled out. Because it was transient in nature, whatever the cause it was either fixed or the cause dissipated. One additional feature is evident in the $S$ tank farm wells. In addition to the apparent decline in gradient from the west to east across $S$ tank farm, the difference in water table elevation between upgradient well 299-W23-13 and downgradient well 299-W22-44 has increased since 1995, suggesting a shift in predicted groundwater flow to a more easterly direction is developing. If this trend is sustained, well 299-W22-44 is in an increasingly favorable position to detect contamination from the northern row or two of $S$ tanks. One possible explanation for this more recent change in water table elevations is the termination of discharge to the U-14 ditch that occurred near the northwest corner of S tank farm.

The hydrographs (Figure B.6) for the older wells are more sporadic than for the RCRA wells but suggest some interesting anomalies. For example, the water table elevation for well 299-W23-7 appears to begin to have higher elevations than expected around 1995 and then slowly declines and comes back into trend by 1998 . This time period is not correlated directly with a natural precipitation event (nearest are 1993 and 1996 and 1997). However, there was a fire hydrant leak near this well that was discovered in early 1997 that was subsequently repaired. Also, the occurrence of a low specific conductance in this well for 1997 that persisted after that time is additional circumstantial evidence for a local source of water.

The monthly measurements of water level in the older wells, made between 1990 and 1995 (Figure B.2), indicate at least one time interval that might correlate with the 1993 episode of rapid snow melt. For example wells 299-W23-1, -2 , and -7 indicate a flattening or resistance to the downward trend line around or shortly after January 1993, which was the largest rapid snow melt on record since 1980. The other wells shown in Figure B.2 do not appear to exhibit a pronounced flattening in water table elevation during this period. All three of these older wells are located along the east side of the S and SX tank farms where a low spot exists and the adjacent ground surface outside of the fence slopes upward to the east. Thus, conditions are conducive to accumulation of surface runoff along the east side of the two tank 
farms. The monthly measurements were not continued after 1995 so it is not possible to determine if the apparent departure from the downward trend in water level was repeated during the 1996 and 1997 rapid snow melt events.

The possible correlations discussed above are subtle and would require more rigorous analysis to 'determine the robustness of the apparent correspondence between snowmelt events and water level. 
We agree there is widespread surface contamination in and around the tank farms. The spills and bumps that occurred are well known. The significance of these broadly distributed surface contamination sites is not so clear. For example, RCRA monitoring well 299-W22-39 was drilled in the midst of a major spill from a diversion box that occurred in the past. Yet, the gamma log for this well (Appendix A of PNNL-11810) does not indicate activity levels above natural background. Even the higher surface concentrations of cesium-137 in the SX farm reported in DOE (1996) are generally in the 1 to $100 \mathrm{pCi} / \mathrm{g}$ range. The highest concentrations are 1,000 to $10,000 \mathrm{pCi} / \mathrm{g}$ (Figure 17, DOE 1996) located in the vicinity of the tanks in the south central to southwest area of SX tank farm. Interestingly, this general location is also where the major contributors to the highest subsurface contamination from tank leaks occurred (e.g., near SX-108, 109 and SX-114, SX-115). These are the same areas considered as the most likely source(s) of groundwater contamination from SX tank farm as discussed in PNNL-11810 (see Figures 4.1 and 4.2) and which were identified as areas of both surface contamination as wells as the largest subsurface leak sites. Thus surface contamination was not ignored. An overlay of the highest surface contamination zones from the MACTEC SX tank farm report (DOE 1996) would not be much different than the zones indicated in Figure 4.2 of PNNL-11810. However, it is also likely that the largest leaks and most intense sources have the highest probability of contributing mobile contaminants to groundwater. Therefore, from the principle of materiality, the large tank leak source areas are considered to be the most likely contributors to groundwater contamination. This does not rule out other locations as possible contributors to groundwater contamination under the right conditions.

There is disagreement over the significance of "broadly distributed low concentrations of cesium137 ' $(0.1$ to $1 \mathrm{pCi} / \mathrm{g})$. One possibility is that it is an artifact of the logging and/or due to casing drag down. The Expert Panel and others have considered this subject. No conclusion has been reached concerning the validity or significance of the very low cesium-137 reported in the MACTEC S and SX tank farm reports (DOE 1996, DOE 1998). Shape factor analysis has been applied to address this issue more recently but the jury is still out. Analysis of results from borehole 41-08-39 using both core sample results and shape factor analysis suggest the low concentrations of cesium-137 in the deeper ( $>135 \mathrm{ft})$ sections are due to drag down. MACTEC data was presented during RCRA Facility Investigation data quality objective meeting, March 2, 1999. The overall issue of the depth distribution of broadly distributed, low-level cesium-137 is one issue that hopefully will be further addressed by planned new drilling in the SX tank farm. 


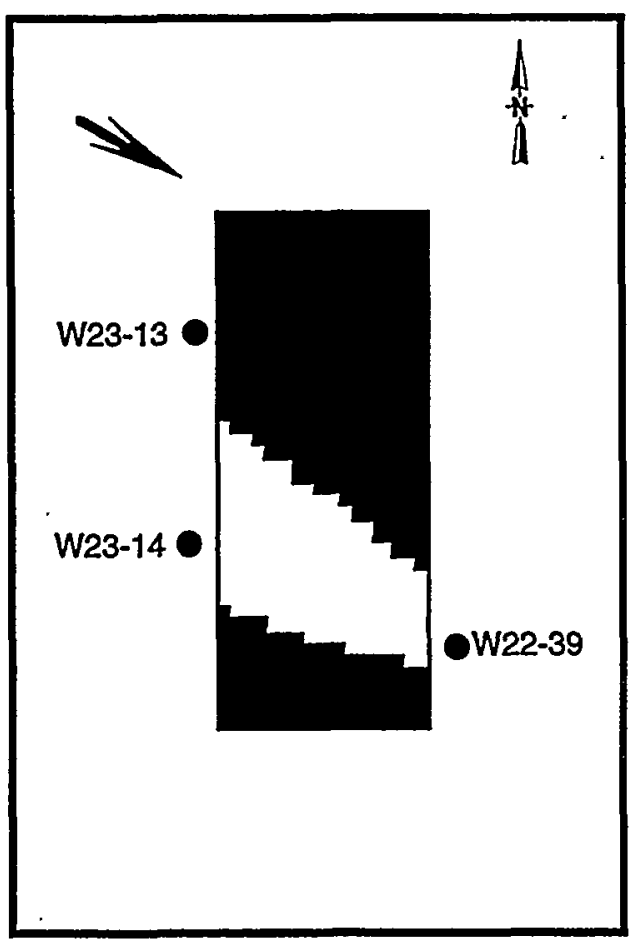

\section{Waste Management Area S-SX EXISTING RCRA NETWORK.}

- Existing Shallow Monitoring Well

- Area Where Leak Detection Would Be Less Likely Under Projected Groundwater Conditions

Direction of Projected Groundwater Flow for Analysis

Potential Source Area

Buffer Zone Boundary

Monitoring Efficiency $=28.6 \%$

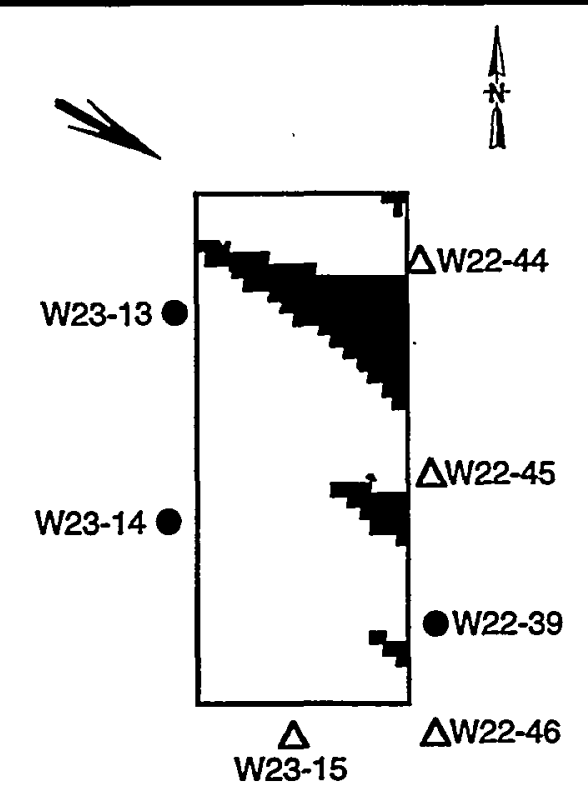

Waste Management Area S-SX PROPOSED RCRA NETWORK

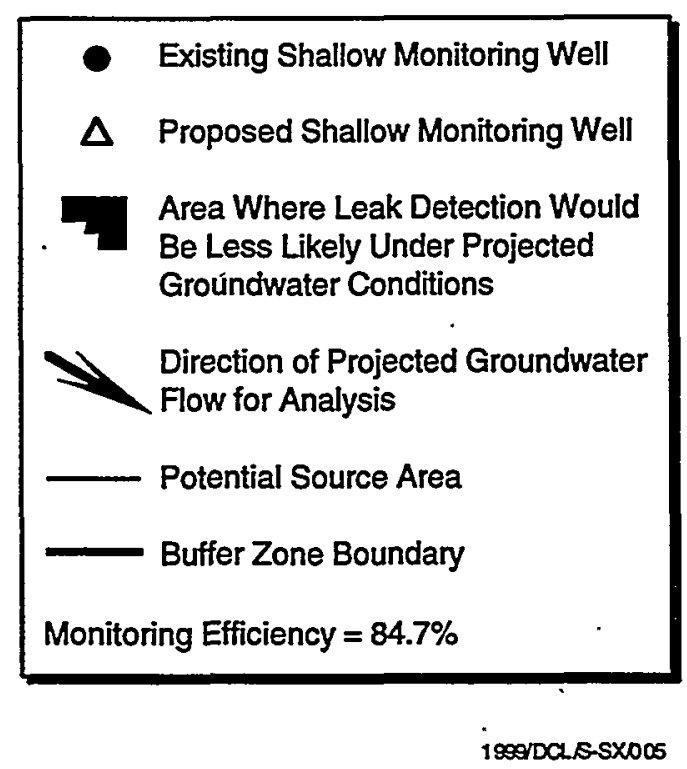

$\triangle W 22-44$ TBD

Figure B.1. MEMO Results for Waste Management Area S-X (1991) 


\section{Figure B.1 MEMO Results for Waste Management Area S-SX (1991).}

The results shown are for the original placement of the RCRA compliant network. Until very recently, the flow direction has been about the same as indicated for the 1991 simulation (Figure B.1). The well locations in the lower figure are very close to the existing network of seven RCRA compliant monitoring wells. The figure also illustrates the area in the $S$ tank farm with deficient spatial coverage based only on the RCRA wells. Wells 299-W23-1and 299-W23-7 provide coverage that reduces the size or area of the wedge (area of non-coverage) indicated.

The groundwater flow direction at the northern end of $S$ tank farm is becoming more easterly. This may in part be due to the termination of wastewater discharges during 1995 to the U-14 ditch near the northwest corner of Waste Management Area S-SX. This will improve the likelihood of well 299-W22-44 to intercept possible leakage from the northern row of S farm single-shell tanks. Inclusion of a new well approximately mid-way between well 299-W22-44 and 299-W22-45 will eliminate a major portion of the area not currently covered (black wedge at the northern end of the waste management area) by existing wells. The new well noted above (see Figure 5.3, PNNL-12114) is especially important because the old well (299-W23-1) will be dry in 1 to 2 years. 


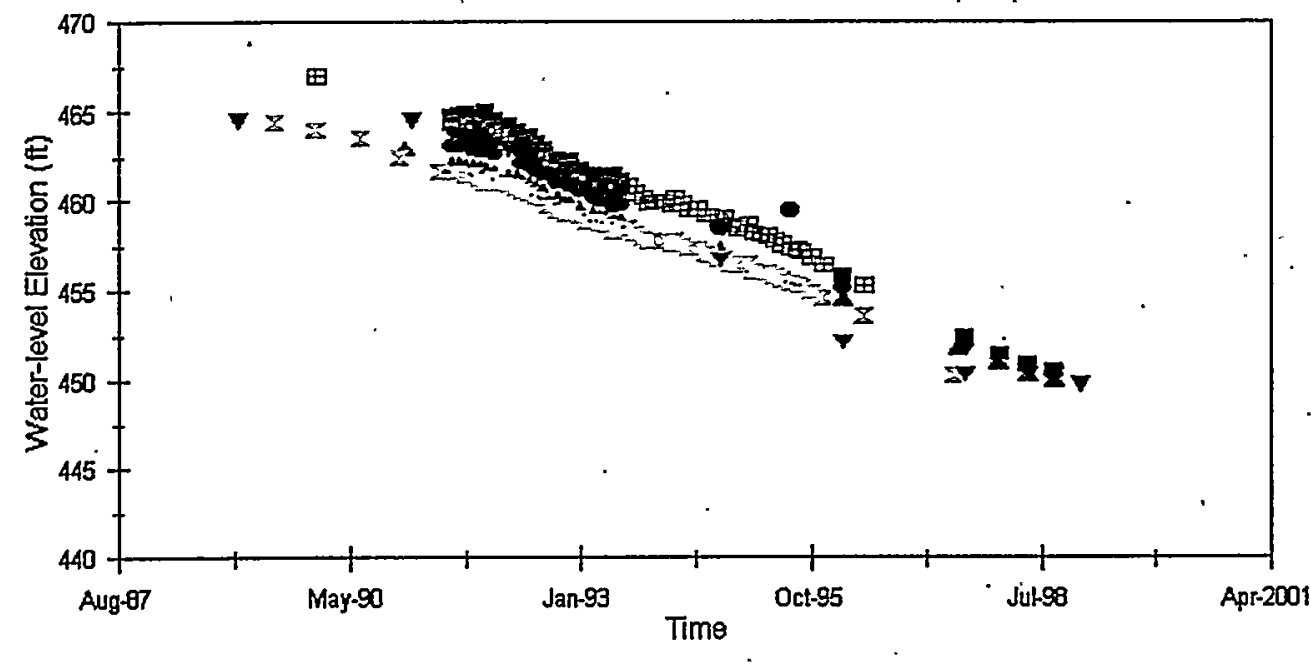

- 299-W23-1-299-W23-2 - 299-W23-3 $\div 299-W 23-6>299-W 23-7$ 甲 299-W23-8

Figure B.2. Hydrographs of Non-RCRA Wells at Waste Management Area S-SX, 1987 to Present

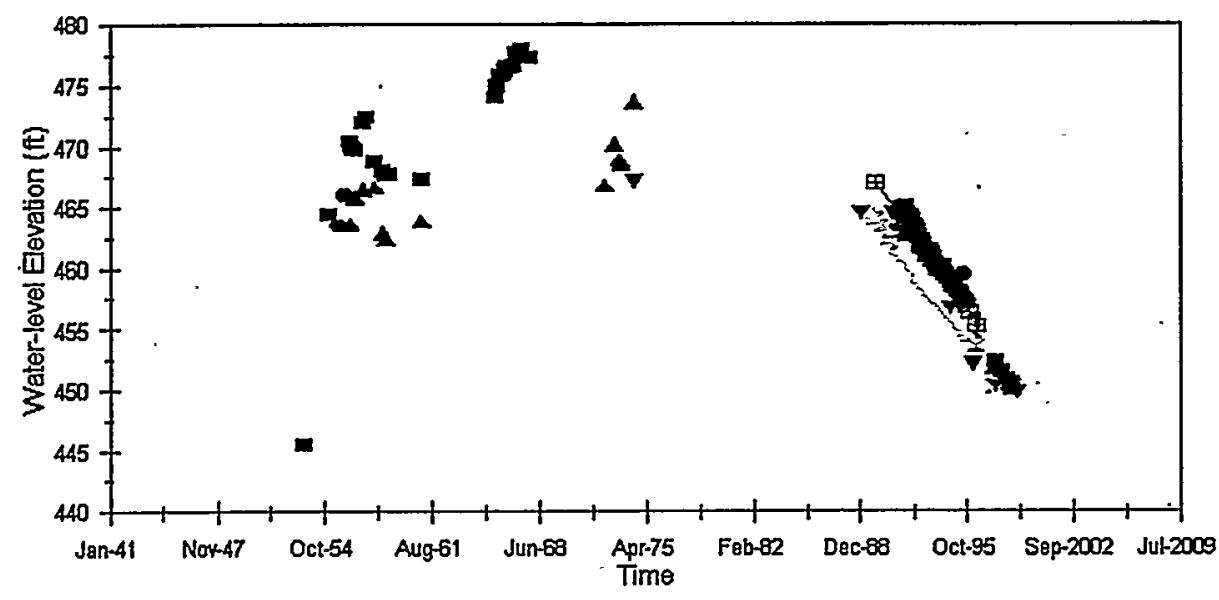

- 299-W23-1 -299-W23-2 + 299-W23-3 $=299-W 23-6>299-W 23-7-7-299-W 23-8$

Figure B.3. Hydrographs of Non-RCRA Wells at Waste Management Area S-SX, 1953 to Present 


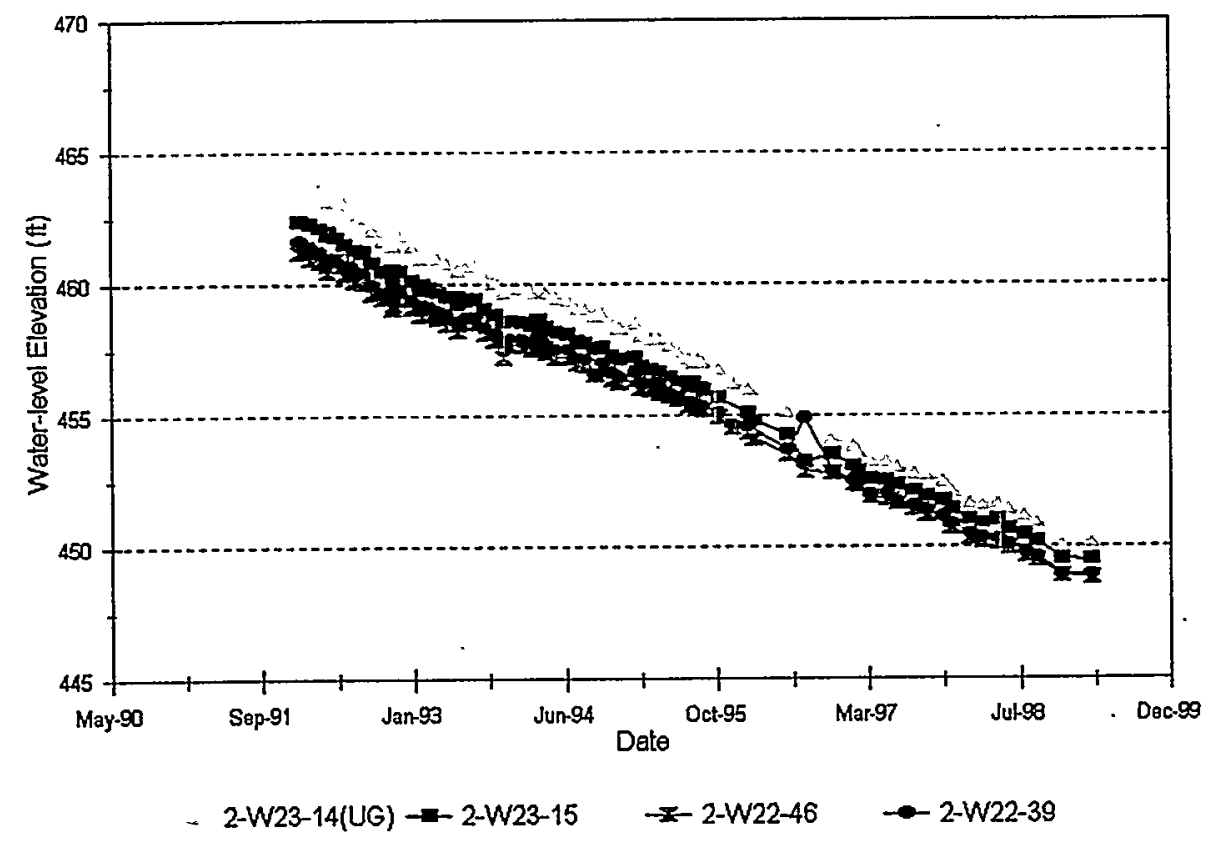

igure B.4. Hydrographs of SX Farm RCRA Wells

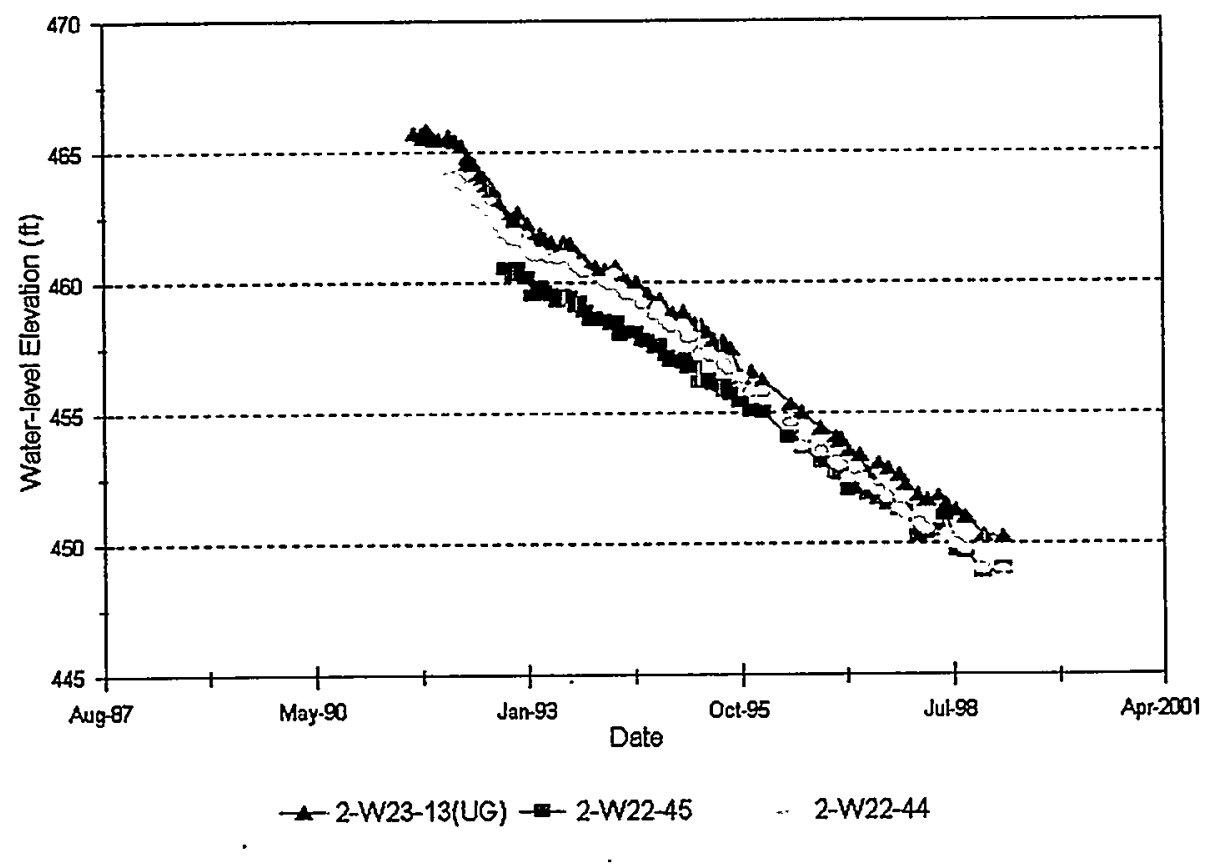

Figure B.5. Hydrographs of S Farm RCRA Wells 


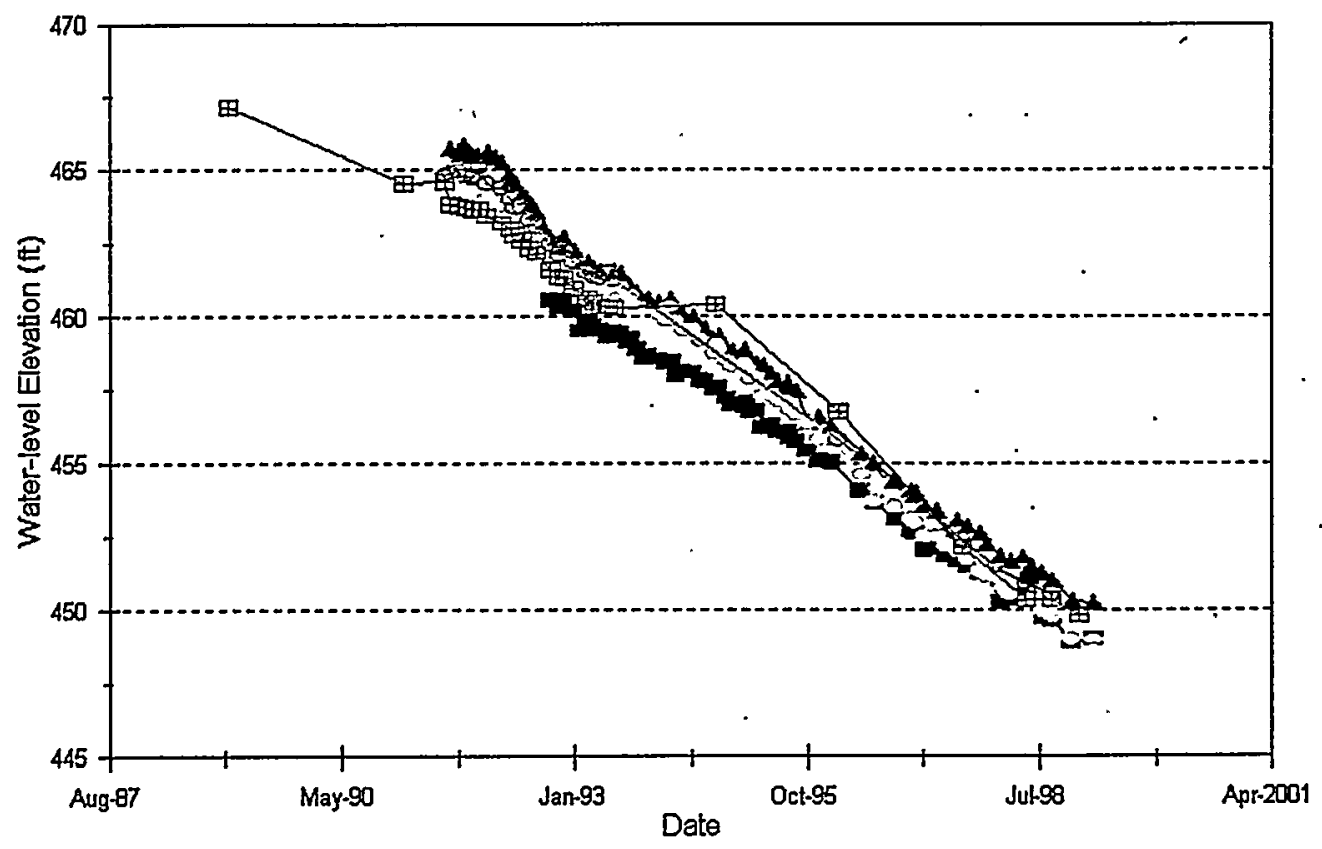

$-2-W 23-13(U G) \rightarrow-2-W 22-45 \sim 2-W 22-44 \quad-2-W 23-1 \quad$ - $-W 23-7$

Figure B.6. Comparison of Hydrographs for RCRA and Non-RCRA Wells Downgradient of S Farm 


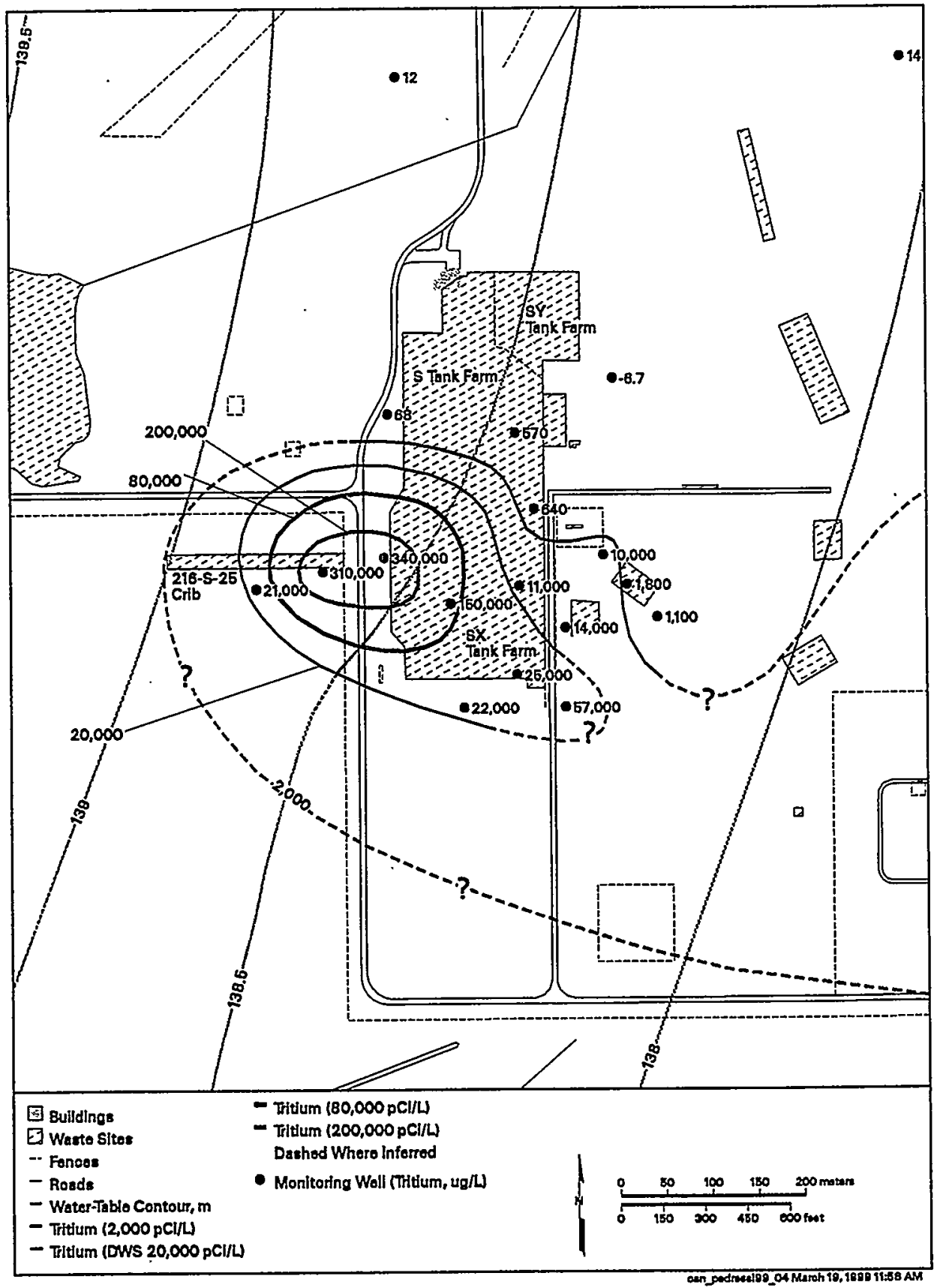

Figure B.7. Tritium Contours and Water Table Map for 200 West Area, 1998 


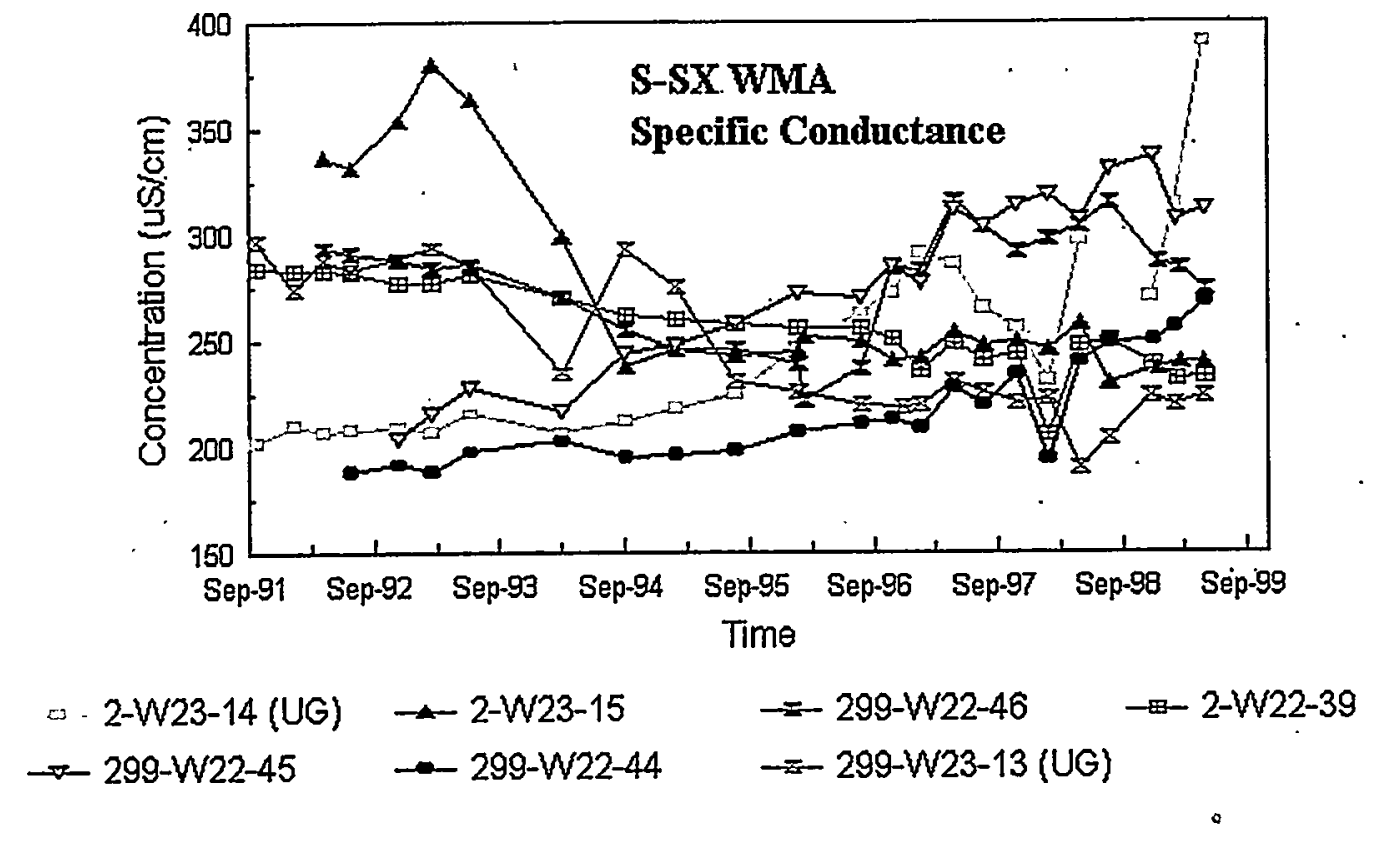

Figure B.8. Specific Conductance for All RCRA Wells at WMA S-SX

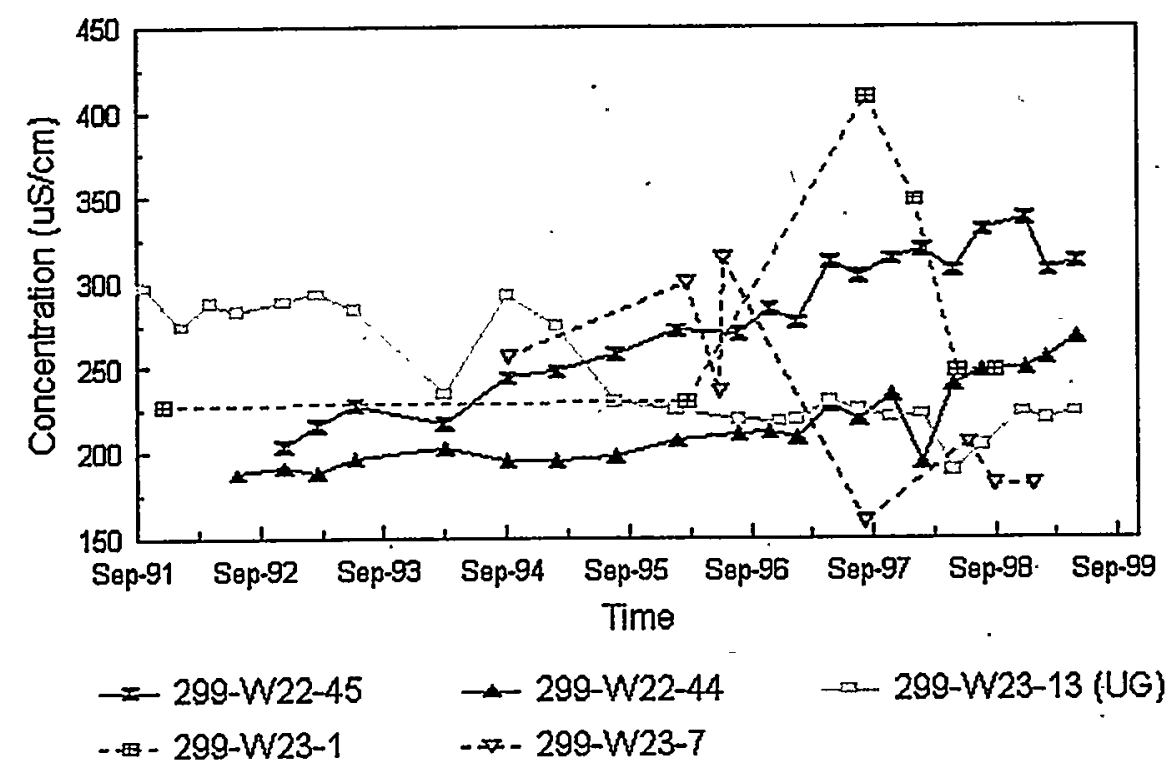

Figure B.9. Specific Conductance for RCRA and Non-RCRA Wells at S Farm 


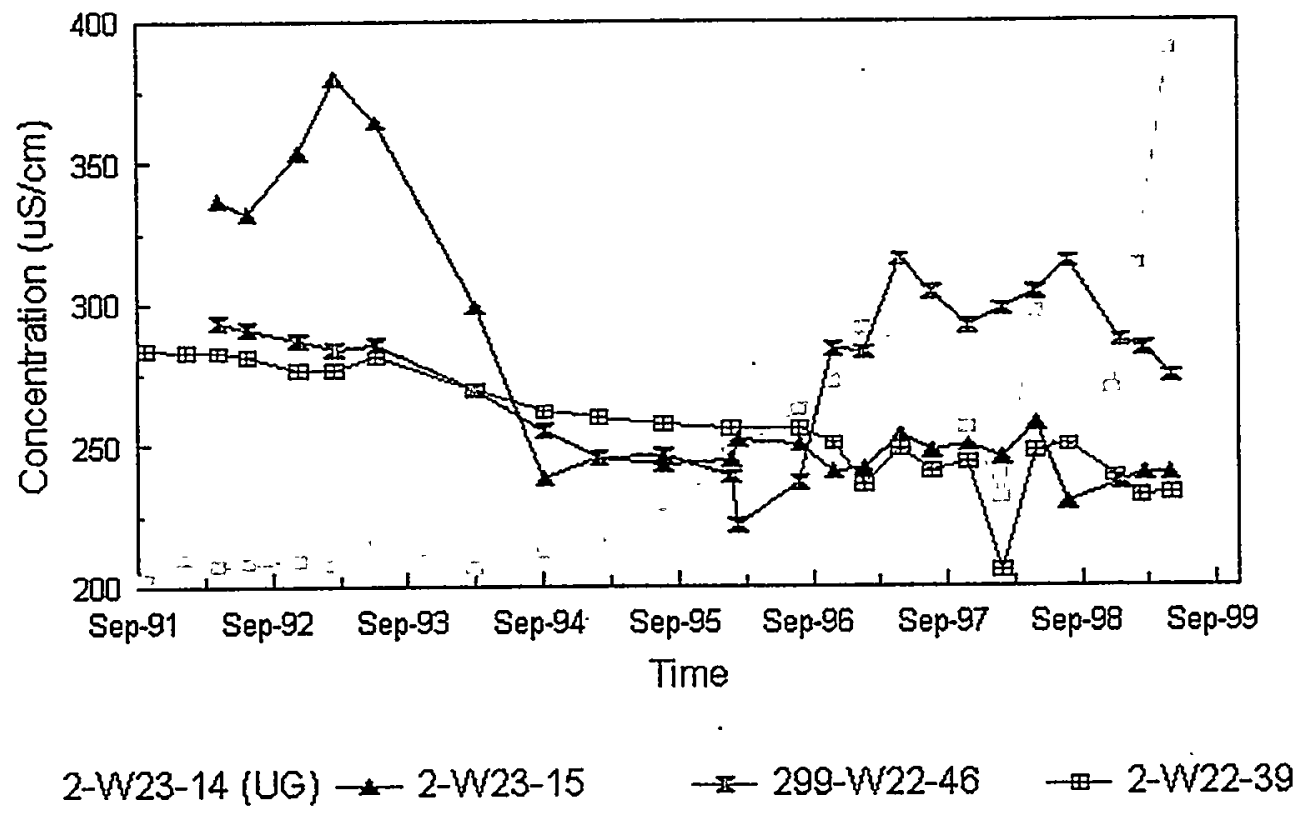

Figure B.10. Specific Conductance for RCRA Wells at SX Farm 
Gross Gamma Log for Well 299-W23-1

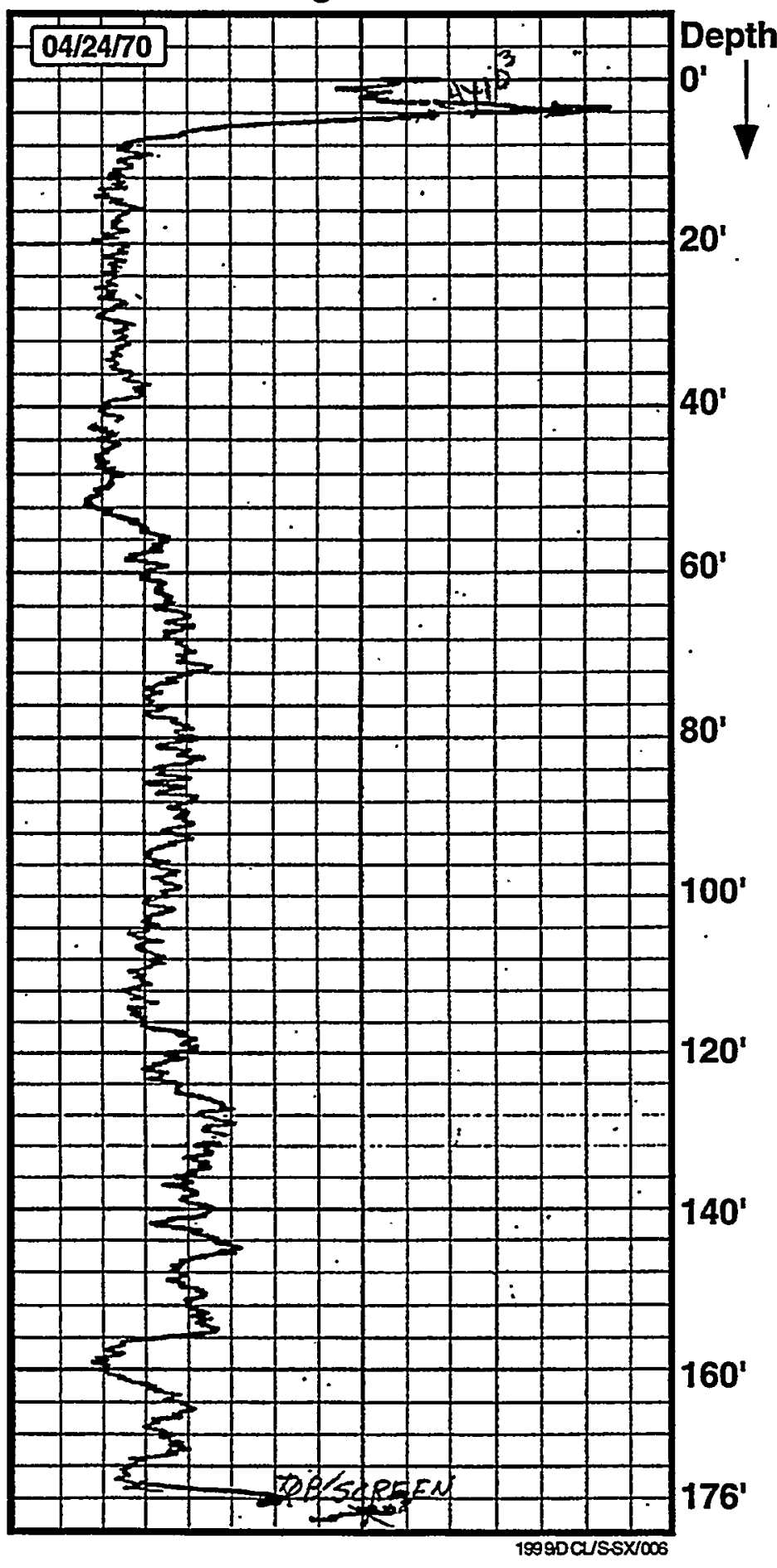

Figure B.11. Ǵross Gamma Log For 299-W23-1, April 24, 1970 
Gross Gamma Log for Well 299-W23-7

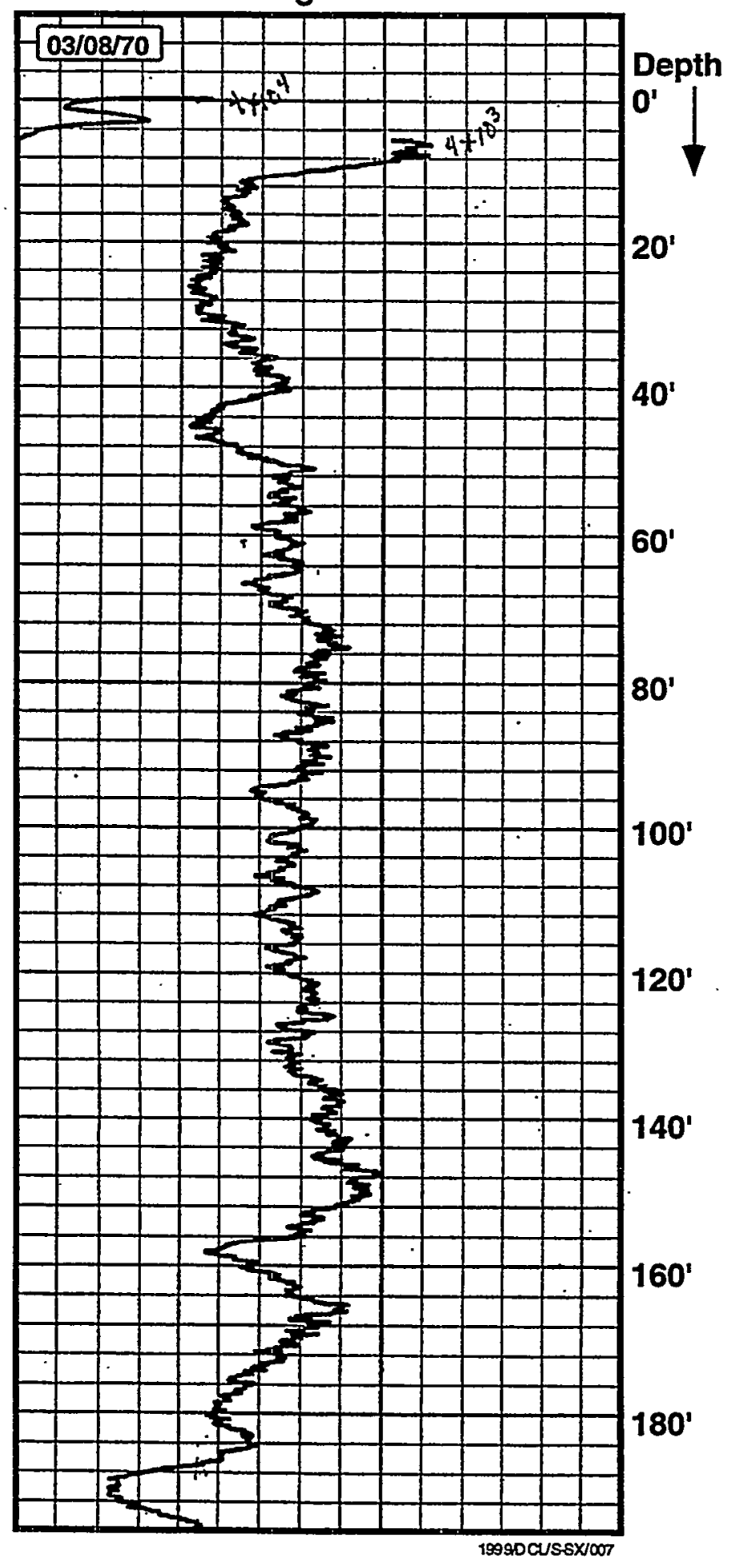

Figure B.12. Gross Gamma Log for 299-W23-7, March 8, 1970 
Data Table 1. This table provides data in reference to comments $56,66,70$, and 77 .

GeODAT Report - 2/27/99

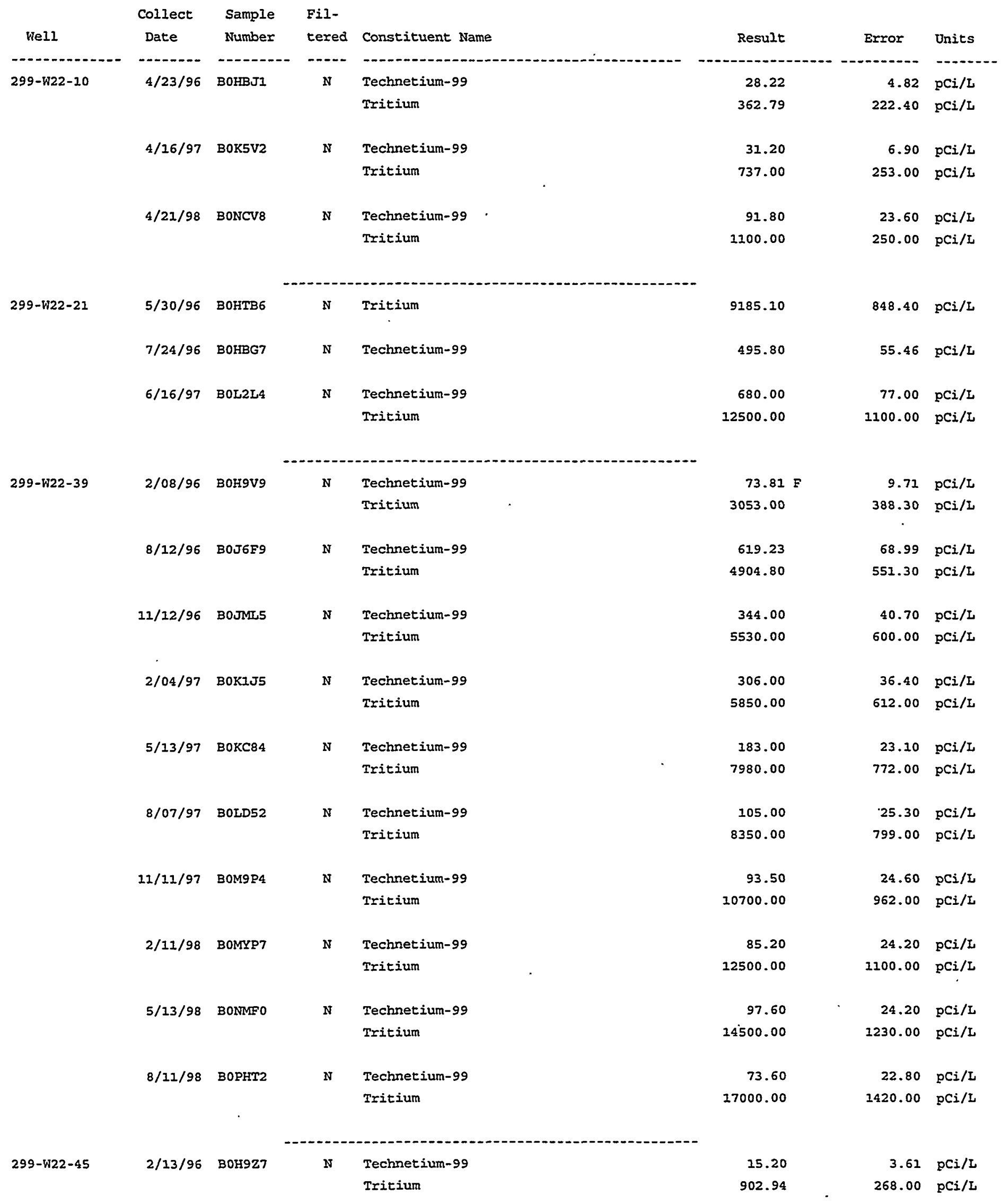




\section{Data Table 1. (contd)}

GeoDAT Report - 2/27/99

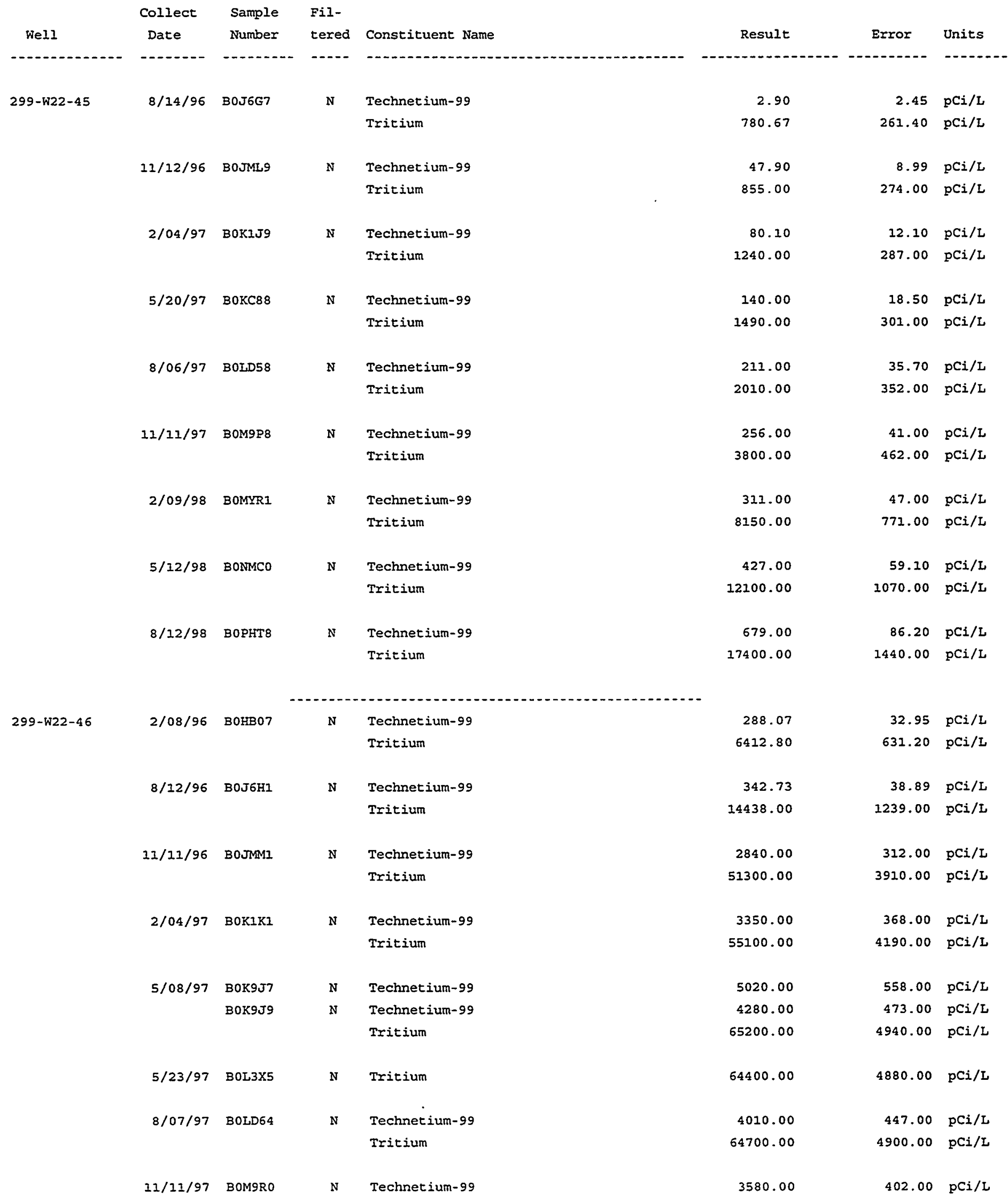




\section{Data Table 1. (contd)}

\begin{tabular}{|c|c|c|c|c|c|c|c|c|}
\hline & & & & & & & & \\
\hline & & & & GeoDAT Report - & $-2 / 27 / 99$ & & & \\
\hline WeII & $\begin{array}{l}\text { Collect } \\
\text { Date }\end{array}$ & $\begin{array}{l}\text { Sample } \\
\text { Number }\end{array}$ & $\begin{array}{l}\text { Fil- } \\
\text { tered }\end{array}$ & Constituent Name & & Result & Error & Units \\
\hline - & -........ & -...-- & $-\ldots$ & 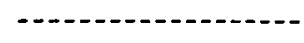 & 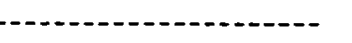 & 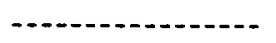 & ------- & $\cdots-$ \\
\hline 299-W22-46 & $11 / 11 / 97$ & BOMgRO & $\mathrm{N}$ & Tritium & & 60700.00 & 4600.00 & $\mathrm{pCi} / \mathrm{L}$ \\
\hline & $2 / 05 / 98$ & BOMYL3 & $\mathbf{N}$ & Technetium-99 & & 4110.00 & 460.00 & $\mathrm{pCi} / \mathrm{L}$ \\
\hline & & & & Tritium & & 58700.00 & 4450.00 & $\mathrm{pCi} / \mathrm{L}$ \\
\hline & $5 / 13 / 98$ & BONMC2 & $\mathrm{N}$ & Technetium-99 & . & 4330.00 & 499.00 & $\mathrm{pCi} / \mathrm{L}$ \\
\hline & & & & Tritium & & 57100.00 & 4330.00 & $\mathrm{pCi} / \mathrm{L}$ \\
\hline . & $8 / 11 / 98$ & BOPHVO & $\mathbf{N}$ & Technetium-99 & & 4330.00 & 492.00 & $\mathrm{pCi} / \mathrm{L}$ \\
\hline & & & & Tritium & & 52300.00 & 3980.00 & $\mathrm{pCi} / \mathrm{L}$ \\
\hline 299-W23-1 & $3 / 11 / 96$ & BOHN4 0 & $\mathbf{N}$ & Technetium-99 & & 180.96 & 21.16 & $\mathrm{pCi} / \mathrm{L}$ \\
\hline & . & & & Tritium & & -37.32 & 200.80 & $\mathrm{pCj} / \mathrm{L}$ \\
\hline & $8 / 28 / 97$ & BOLN11 & $\mathbf{N}$ & Technetium-99 & & 1490.00 & 174.00 & $\mathrm{pCi} / \mathrm{L}$ \\
\hline & & & & Tritium & & 2490.00 & 403.00 & $\mathrm{pCi} / \mathrm{L}$ \\
\hline & & BOLN13 & $\mathbf{N}$ & Technetium-99 & & 1150.00 & 137.00 & $\mathrm{pC} \dot{\mathrm{L}} / \mathrm{L}$ \\
\hline & & & & Tritium & & 2600.00 & 410.00 & $\mathrm{pCi} / \mathrm{L}$ \\
\hline - & $1 / 21 / 98$ & BOMX90 & $\mathbf{N}$ & Technerium-99 & & $2890.00 \mathrm{G}$ & 325.00 & $\mathrm{pCi} / \mathrm{L}$ \\
\hline & & B0MX93 & $\mathbf{N}$ & Tritium & & 1010.00 & 281.00 & $\mathrm{pCi} / \mathrm{L}$ \\
\hline & & BOMXN5 & $\mathbf{N}$ & Technetium-99 & & $513.00 \mathrm{PG}$ & 67.70 & $\mathrm{pCi} / \mathrm{L}$ \\
\hline & $5 / 27 / 98$ & BONM26 & $\mathbf{N}$ & Tritium & & 502.00 & 232.00 & $\mathrm{pCi} / \mathrm{L}$ \\
\hline & & BONMY6 & $\mathbf{N}$ & Technetium-99 & & 1170.00 & 138.00 & $\mathrm{pCi} / \mathrm{L}$ \\
\hline & $9 / 16 / 98$ & BOPR4I & $\mathbf{N}$ & Technetium-99 & & 624.00 & 79.70 & $\mathrm{pCi} / \mathrm{L}$ \\
\hline & & & & Tritium & & $202.00 \mathrm{U}$ & 217.00 & $\mathrm{pCi} / \mathrm{L}$ \\
\hline 299-W23-13 & $2 / 07 / 96$ & BOHBI7 & $\mathbf{N}$ & Technetium-99 & & $1.74 \mathrm{U}$ & 2.38 & $\mathrm{pCi} / \mathrm{L}$ \\
\hline & & & & Tritium & & $148.86 \mathrm{U}$ & 206.30 & $\mathrm{pCi} / \mathrm{L}$ \\
\hline & $8 / 08 / 96$ & BOJ6H5 & $\mathbf{N}$ & Technetium-99 & & .15 & 2.21 & $\mathrm{pCi} / \mathrm{L}$ \\
\hline & & & & Tritium & & 164.69 & 225.50 & $\mathrm{pCi} / \mathrm{L}$ \\
\hline & $11 / 07 / 96$ & BOJMM3 & $\mathbf{N}$ & Technetium-99 & & $.84 \mathrm{U}$ & 4.56 & $\mathrm{pCi} / \mathrm{L}$ \\
\hline & & & & Tritium & & $-81.10 \mathrm{U}$ & 214.00 & $\mathrm{pCi} / \mathrm{L}$ \\
\hline & $2 / 06 / 97$ & BOK1K3 & $\mathbf{N}$ & Technetium-99 & & $1.32 \mathrm{U}$ & 4.63 & $\mathrm{pCi} / \mathrm{L}$ \\
\hline & & & & Tritium & & $157.00 \mathrm{U}$ & 216.00 & $\mathrm{pCi} / \mathrm{L}$ \\
\hline & $5 / 07 / 97$ & ВоКС92 & $N$ & Technetium-99 & & $1.90 \mathrm{U}$ & 4.52 & $\mathrm{pCi} / \mathrm{L}$ \\
\hline & & & & Tritium & & $184.00 \mathrm{U}$ & 219.00 & $\mathrm{pCi} / \mathrm{L}$ \\
\hline & $8 / 07 / 97$ & BOLD67 & $\mathbf{N}$ & Technetium-99 & & $.27 \mathrm{U}$ & 16.00 & $\mathrm{pCi} / \mathrm{L}$ \\
\hline & & & & Tritium & & 222.000 & 219.00 & $\mathrm{pCi} / \mathrm{L}$ \\
\hline & $11 / 11 / 97$ & Вом9J8 & $\mathbf{N}$ & Technetium-99 & $\cdot$ & $.80 \mathrm{~J}$ & 16.50 & $\mathrm{pCi} / \mathrm{L}$ \\
\hline & & & & Tritium & & $138.00 \mathrm{U}$ & 205.00 & $\mathrm{pCi} / \mathrm{L}$ \\
\hline
\end{tabular}




\section{Data Table 1. (contd)}

\section{GeODAT Report - 2/27/99}

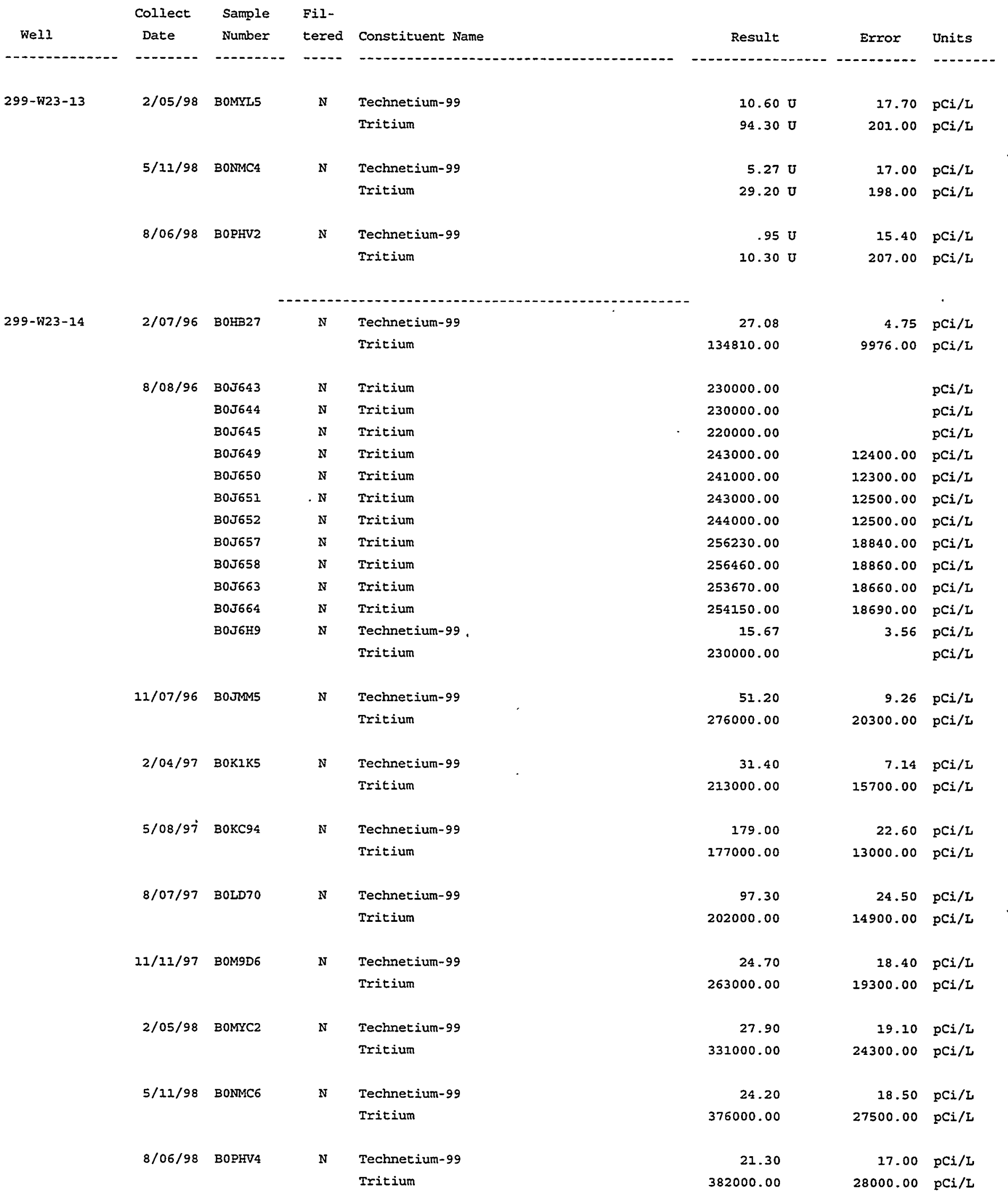




\section{Data Table 1. (contd)}

GeoDAT Report - 2/27/99

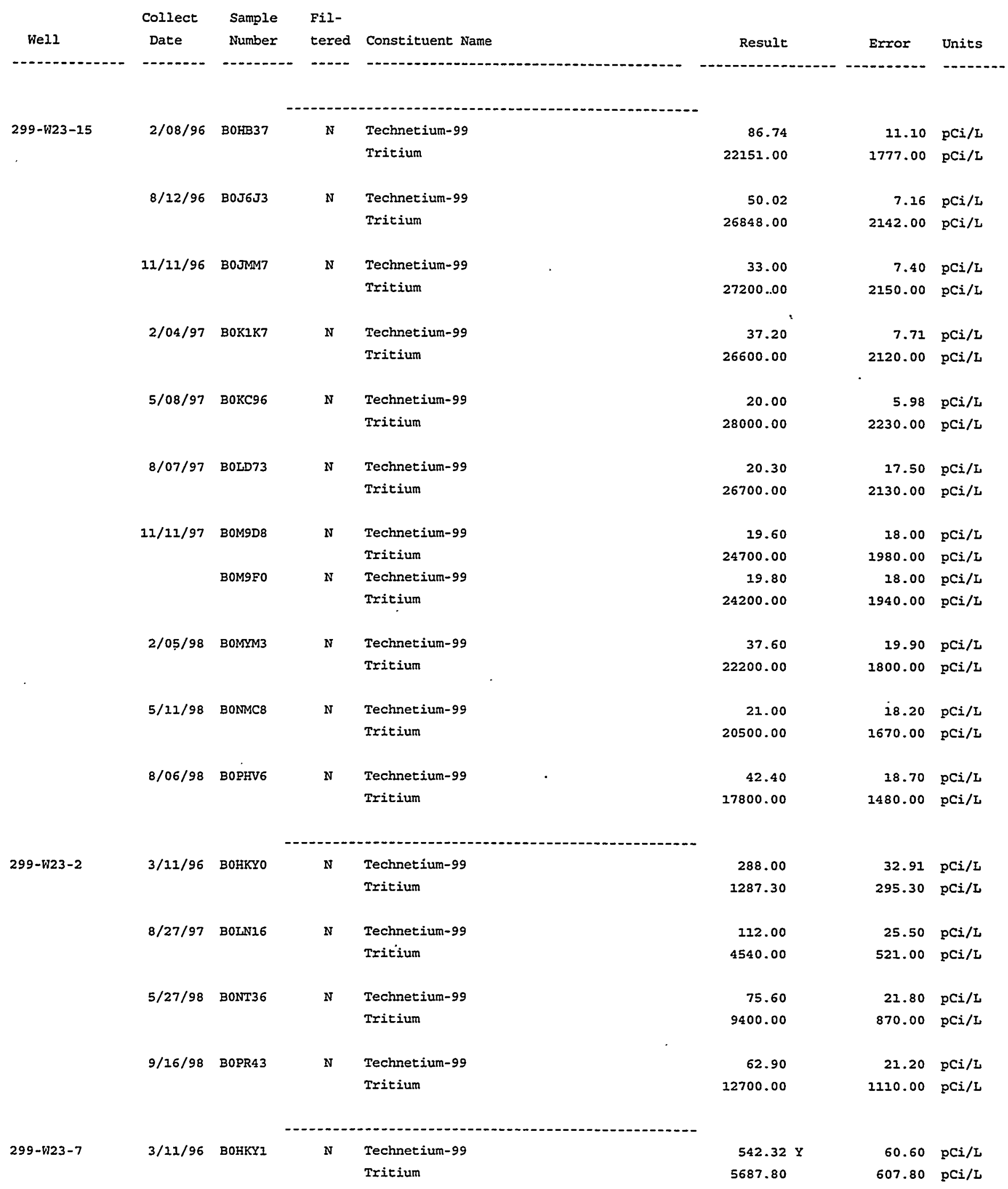


Data Table 1. (contd)

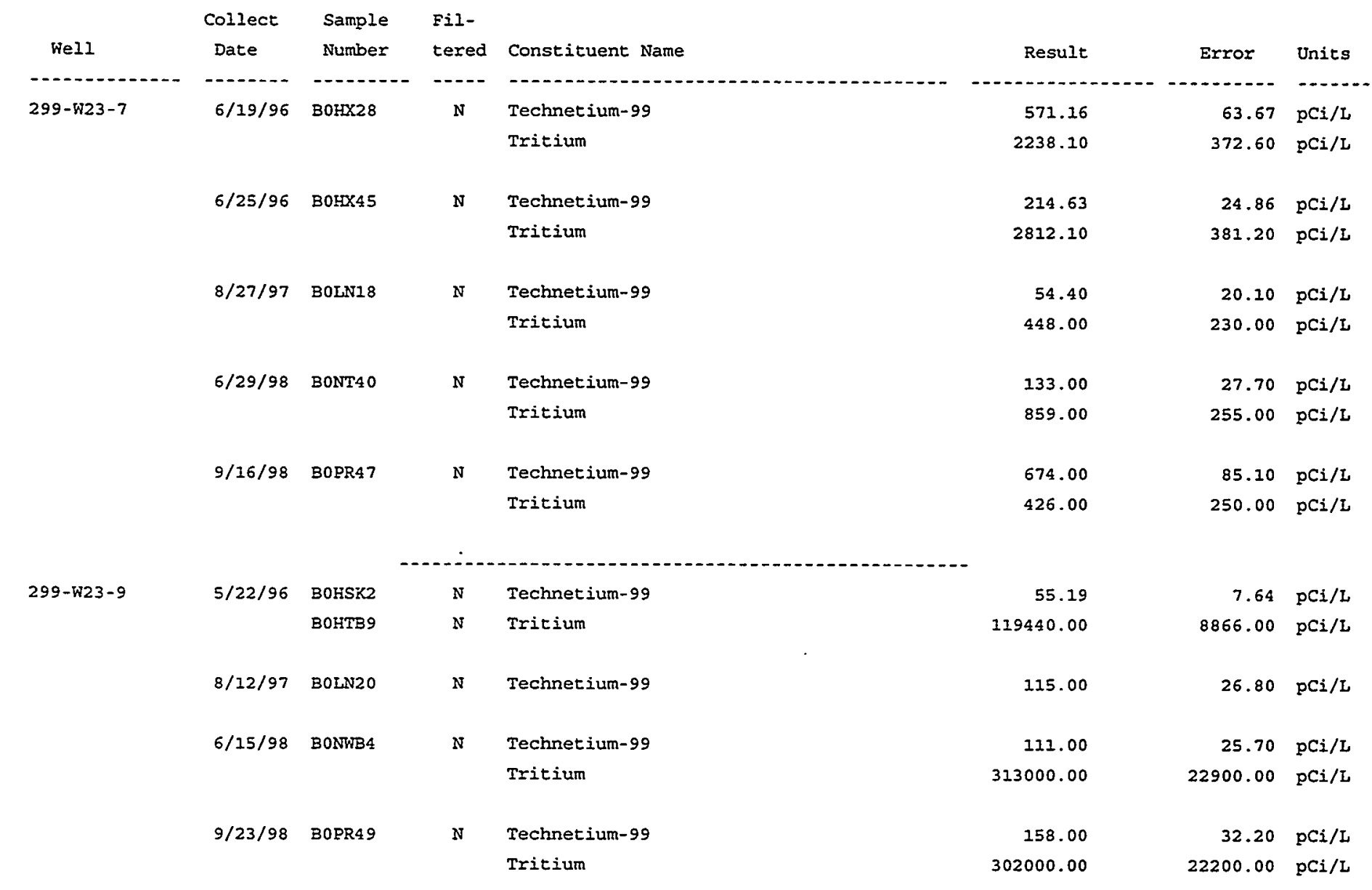


Data Table 1. (contd)

GeodAT Report - 2/26/99

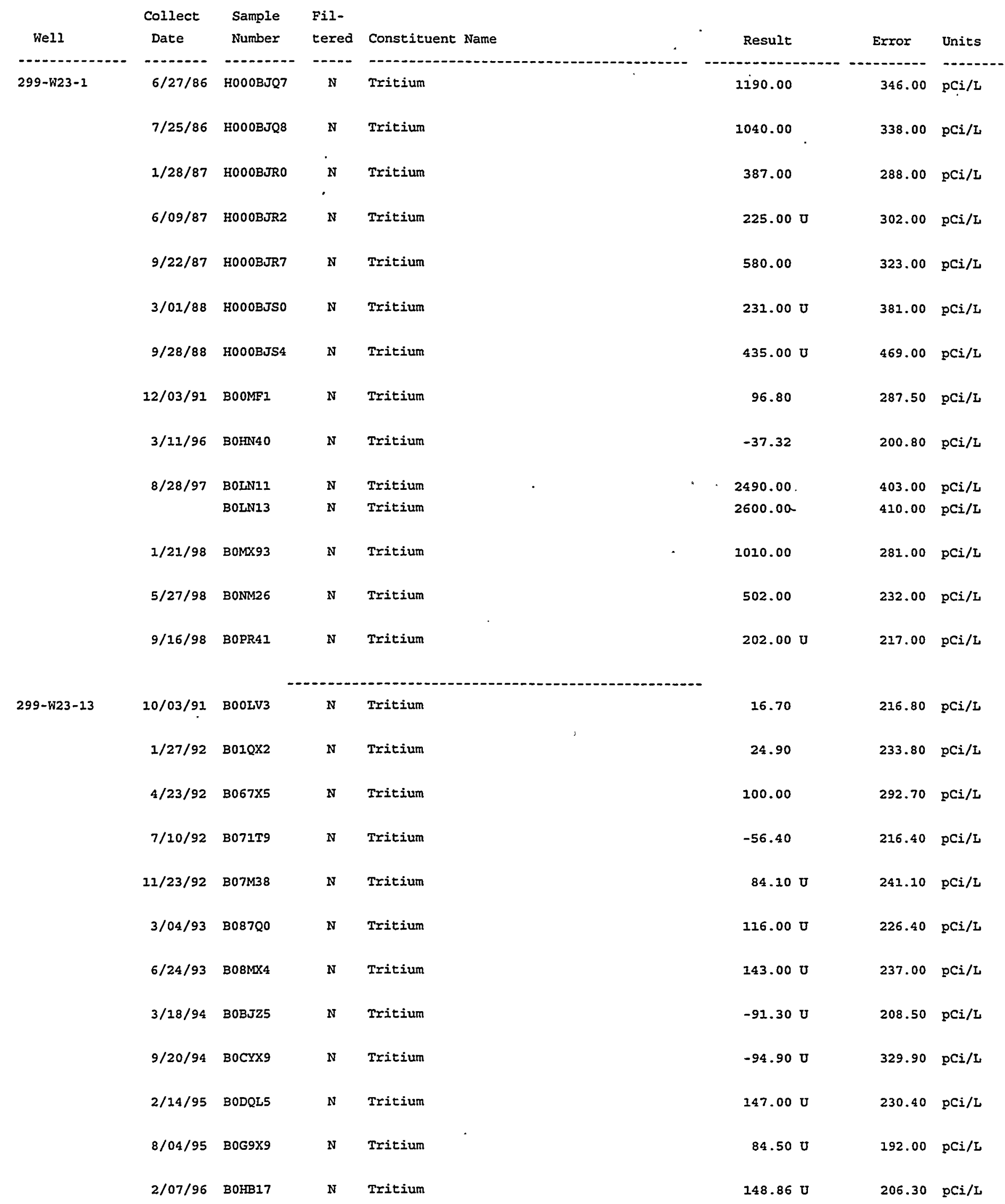




\section{Data Table 1. (contd)}

\section{GeoDAT Report - 2/26/99}

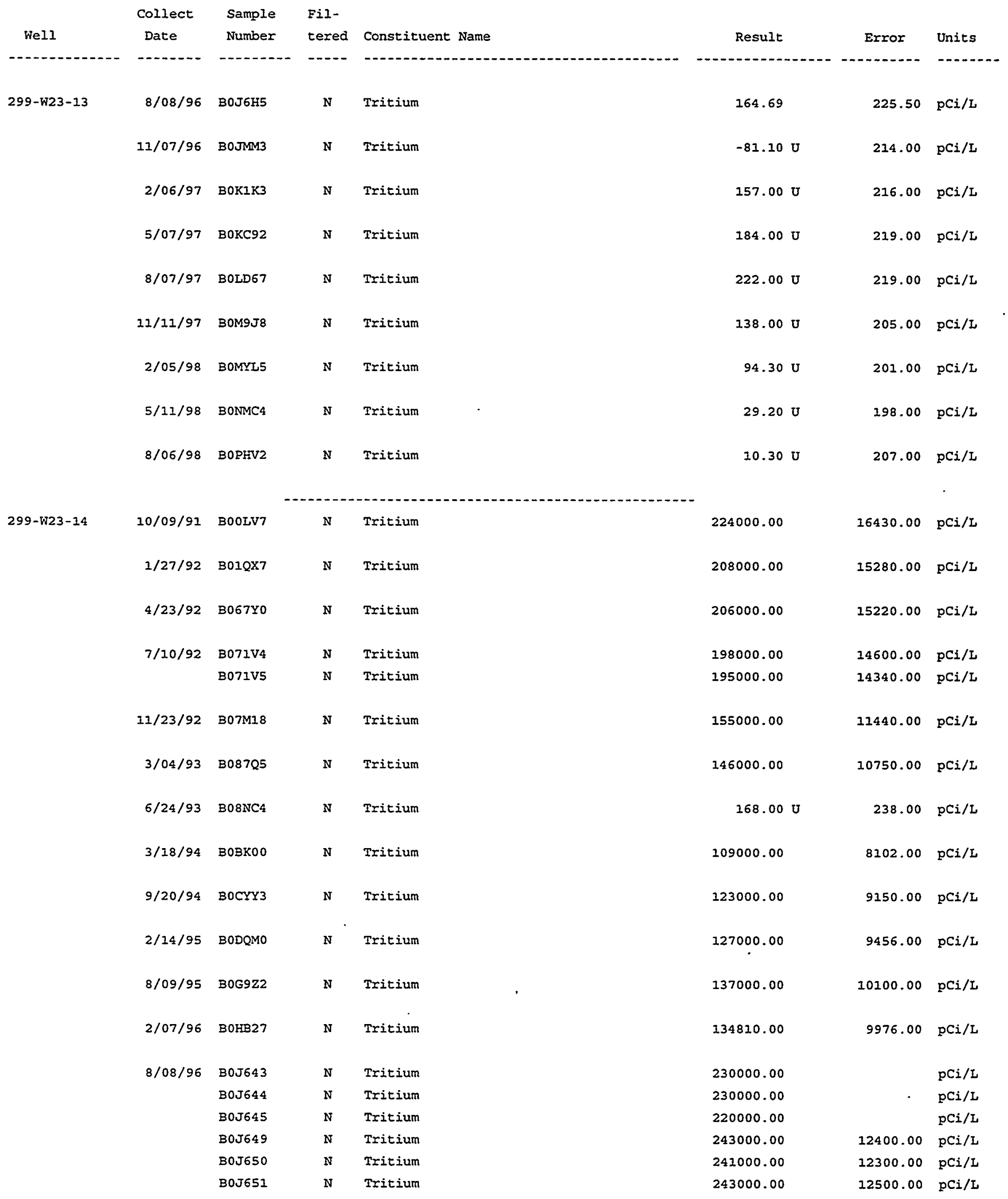




\section{Data Table 1. (contd)}

GeODAT Report - 2/26/99

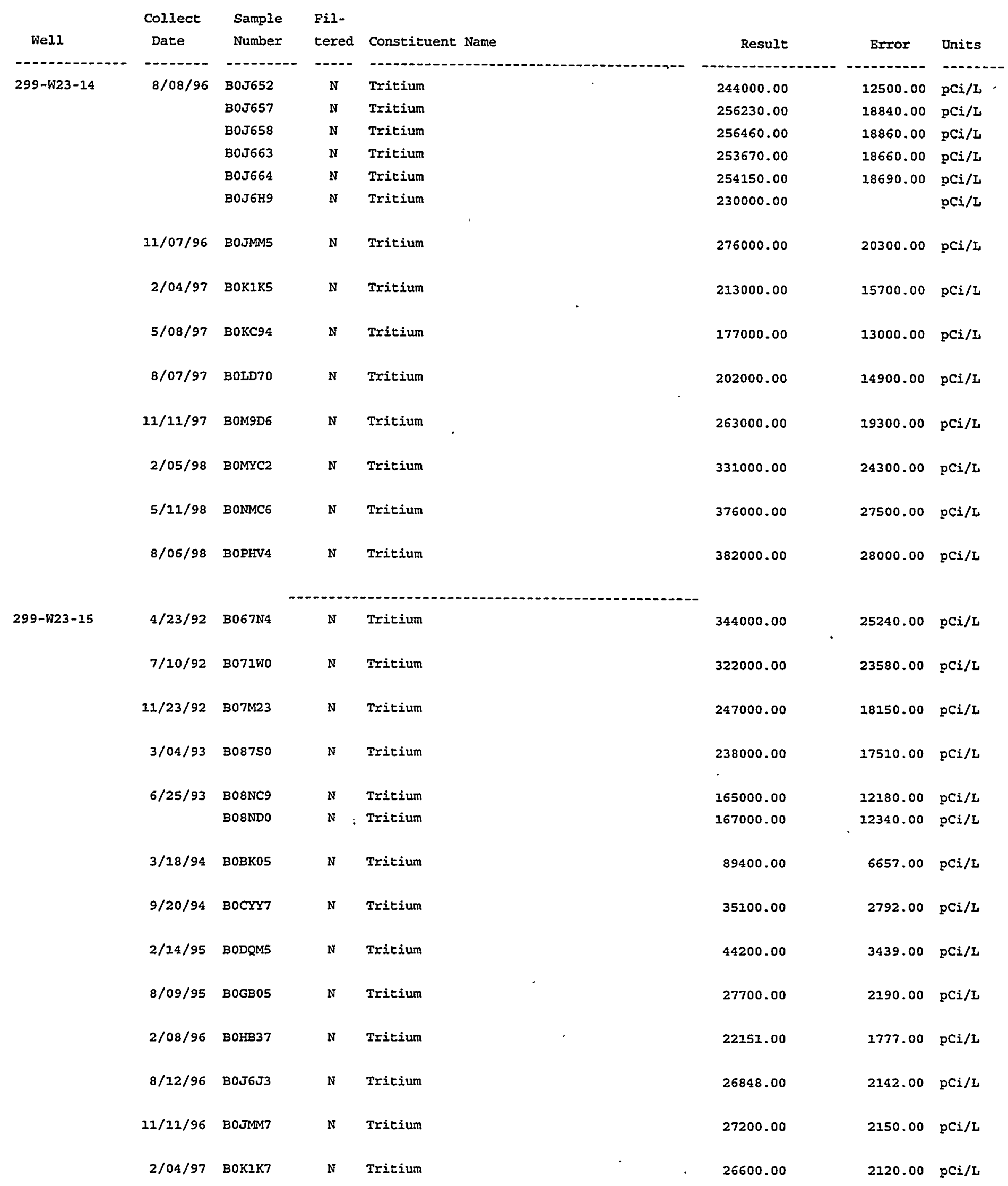


Data Table 1. (contd)

GeoDAT Report - 2/26/99

\begin{tabular}{|c|c|c|c|c|c|c|c|}
\hline Well & $\begin{array}{l}\text { Collect } \\
\text { Date }\end{array}$ & $\begin{array}{l}\text { Sample } \\
\text { Number }\end{array}$ & $\begin{array}{l}\text { Fil- } \\
\text { cered }\end{array}$ & Constituent Name & Result & Error & Units \\
\hline - n-n-n-n & 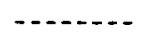 & 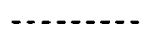 &.--- & - & - & $-\ldots-n$ & 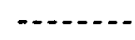 \\
\hline \multirow[t]{7}{*}{$299-$ W23-15 } & $5 / 08 / 97$ & в0КC96 & $\mathbf{N}$ & Tritium & 28000.00 & 2230.00 & $\mathrm{pCi} / \mathrm{L}$ \\
\hline & $8 / 07 / 97$ & BOLD73 & $\mathrm{N}$ & Tritium & 26700.00 & 2130.00 & $\mathrm{pCi} / \mathrm{L}$ \\
\hline & $11 / 11 / 97$ & BOM9D8 & N & Tritium & 24700.00 & 1980.00 & $\mathrm{pCi} / \mathrm{L}$ \\
\hline & & BOM9FO & $\mathrm{N}$ & Tritium & 24200.00 & 1940.00 & $\mathrm{pCi} / \mathrm{L}$ \\
\hline & $2 / 05 / 98$ & BOMYM3 & $\mathrm{N}$ & Tritium & 22200.00 & 1800.00 & $\mathrm{pCi} / \mathrm{L}$ \\
\hline & $5 / 11 / 98$ & BONMC8 & $\mathrm{N}$ & Tritium & 20500.00 & 1670.00 & $\mathrm{pCi} / \mathrm{L}$ \\
\hline & $8 / 06 / 98$ & BOPHV6 & $\mathrm{N}$ & Tritium & 17800.00 & 1480.00 & $\mathrm{pCi} / \mathrm{L}$ \\
\hline
\end{tabular}


Data Table 2. This table provides data in reference to comment 93.

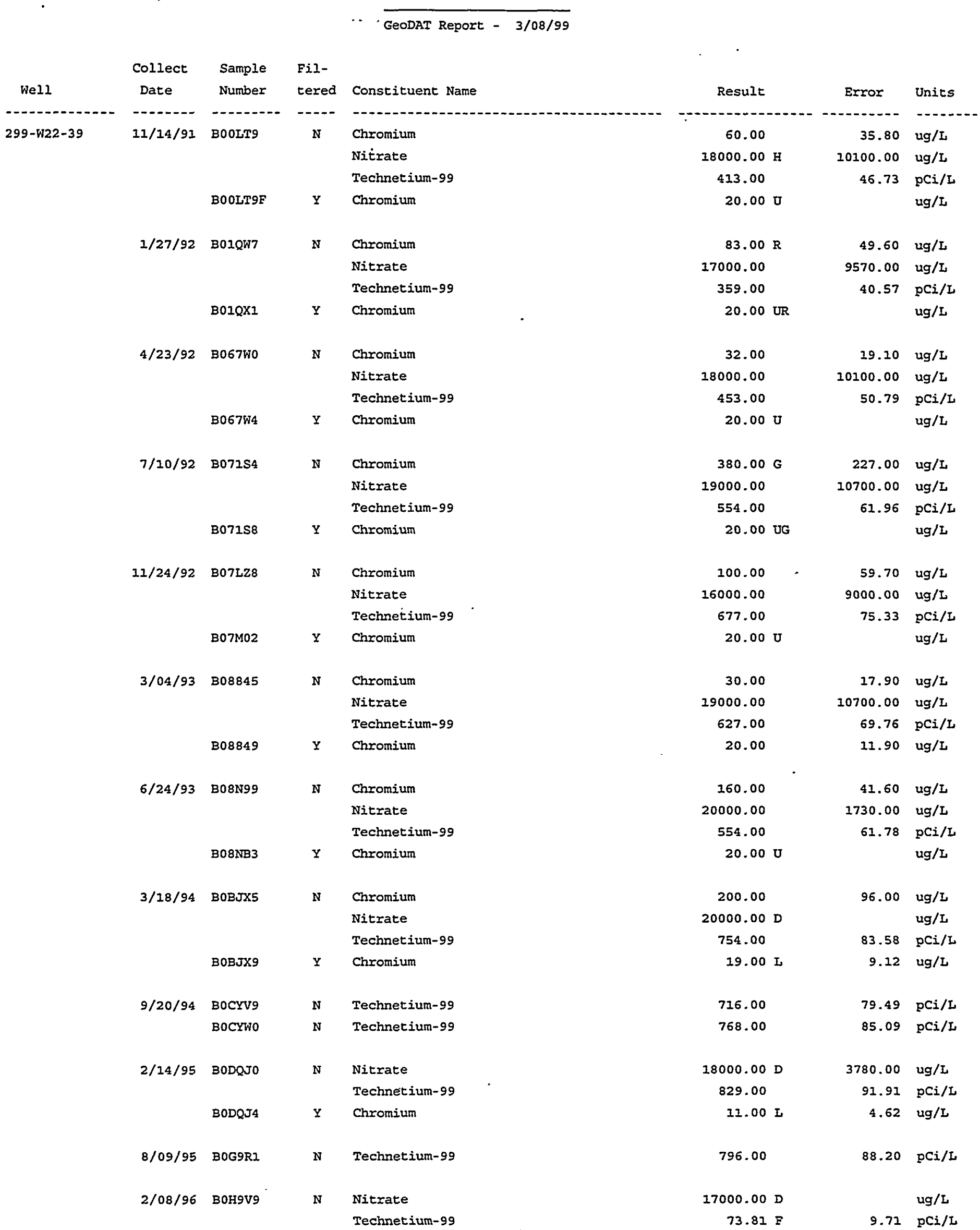




\begin{tabular}{|c|c|c|c|c|c|c|c|c|}
\hline & - & & & Data Table 2. ( & contd) & & & \\
\hline & & & & GeoDAT Report - & $3 / 08 / 99$ & & & \\
\hline พell & $\begin{array}{l}\text { Collect } \\
\text { Date }\end{array}$ & $\begin{array}{l}\text { Sample } \\
\text { Number }\end{array}$ & $\begin{array}{l}\text { Fil- } \\
\text { tered }\end{array}$ & Constituent Name & & Result & Error & Units \\
\hline n & 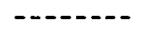 & 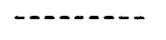 & --- & 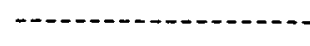 & - & 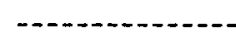 & 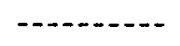 & $-\cdots$ \\
\hline 299-W22-39 & $2 / 08 / 96$ & Вон9W3 & $Y$ & Chromium & & 12.00 & 5.04 & ug $/ \mathrm{L}$ \\
\hline & $8 / 12 / 96$ & B0J6F9 & $\mathrm{N}$ & Technetium-99 & & 619.23 & 68.99 & $\mathrm{pCi} / \mathrm{L}$ \\
\hline & $11 / 12 / 96$ & BOJML5 & N & Nitrogen in Nitrate & & $3.33 \mathrm{DQ}$ & & $\mathrm{mg} / \mathrm{L}$ \\
\hline & & & & Technetium-99 & & 344.00 & 40.70 & $\mathrm{pCi} / \mathrm{L}$ \\
\hline & & B0JML6 & $\mathrm{Y}$ & Chromium & & $7.10 \mathrm{~B}$ & & $\mathrm{ug} / \mathrm{L}$ \\
\hline & $2 / 04 / 97$ & BOKIJ5 & $\mathbf{N}$ & Nitrogen in Nitrate & & $2.78 \mathrm{DH}$ & & $\mathrm{mg} / \mathrm{L}$ \\
\hline & & & & Technetium-99 & & 306.00 & 36.40 & $\mathrm{pCi} / \mathrm{I}$ \\
\hline & & BOKIJ6 & $\mathbf{Y}$ & Chromium & & $7.40 \mathrm{~B}$ & & $\mathrm{ug} / \mathrm{t}$ \\
\hline & $5 / 13 / 97$ & BoKC84 & $\mathrm{N}$ & Nitrogen in Nitrate & & $2.60 \mathrm{D}$ & & $\mathrm{mg} / \mathrm{L}$ \\
\hline & & & & Technetium-99 & & 183.00 & 23.10 & $\mathrm{pCi} / \mathrm{L}$ \\
\hline & & B0KC85 & $Y$ & Chromium & & $5.10 \mathrm{~B}$ & & $\mathrm{ug} / \mathrm{L}$ \\
\hline & $8 / 07 / 97$ & B0ID52 & $N$ & Nitrogen in Nitrate & & $2.80 \mathrm{D}$ & & $\mathrm{mg} / \mathrm{L}$ \\
\hline & & & & Technetium-99 & & 105.00 & 25.30 & $\mathrm{pCi} / \mathrm{L}$ \\
\hline & & BOLD53 & $Y$ & Chromium & & $4.40 \mathrm{~B}$ & & $\mathrm{ug} / \mathrm{L}$ \\
\hline & $11 / 11 / 97$ & В0M9P3 & $Y$ & Chromium & & $3.50 \mathrm{U}$ & & $u g / L$ \\
\hline & & BOM9P4 & N & Nitrogen in Nitrate & & $2.80 \mathrm{DQ}$ & & $\mathrm{mg} / \mathrm{L}$ \\
\hline & & & & Technetium-99 & & 93.50 & 24.60 & $\mathrm{pCi} / \mathrm{L}$ \\
\hline & $2 / 11 / 98$ & BOMYP6 & $\mathrm{Y}$ & Chromium & & $2.70 \mathrm{U}$ & & ug/L \\
\hline & & BOMYP7 & N & Nitrogen in Nitrate & & $3.17 \mathrm{DH}$ & & $\mathrm{mg} / \mathrm{L}$ \\
\hline & & & & Technetium-99 & & 85.20 & 24.20 & $\mathrm{pCi} / \mathrm{L}$ \\
\hline & $5 / 13 / 98$ & BONMD9 & $\mathbf{Y}$ & Chromium & & $3.60 \mathrm{~B}$ & & $\mathrm{ug} / \mathrm{L}$ \\
\hline & & BONMFO & N & Technerium-99 & & 97.60 & 24.20 & $\mathrm{pCi} / \mathrm{L}$ \\
\hline & & $30 N V 36$ & N & Nitrate & & $13.00 \mathrm{D}$ & & $\mathrm{mg} / \mathrm{L}$ \\
\hline & $8 / 11 / 98$ & BOPHT1 & $\mathbf{Y}$ & Chromium & & $4.20 \mathrm{U}$ & & $\mathrm{ug} / \mathrm{L}$ \\
\hline & & BOPHT2 & $\mathbf{N}$ & Nitrogen in Nitrate & & $3.32 \mathrm{D}$ & & $\mathrm{mg} / \mathrm{L}$ \\
\hline & & & & Technetium-99 & & 73.60 & 22.80 & $\mathrm{pCi} / \mathrm{L}$ \\
\hline & $12 / 15 / 98$ & В0T957 & $\mathbf{Y}$ & Chromium & & $2.80 \mathrm{U}$ & & $\mathrm{ug} / \mathrm{L}$ \\
\hline & & B0T958 & N & Nitrogen in Nitrate & & 3.27 & & $\mathrm{mg} / \mathrm{L}$ \\
\hline $299-$ พ22-44 & $9 / 09 / 92$ & B07159 & N & Chromium & & 50.00 & 29.90 & ug/L \\
\hline & & & & Nitrate & & 700.00 & 394.00 & $\mathrm{ug} / \mathrm{L}$ \\
\hline & & . & & Technetium-99 & & 12.90 & 3.43 & $\mathrm{pCi} / \mathrm{L}$ \\
\hline & & B071T3 & $Y$ & Chromium & & $20.00 \mathrm{U}$ & & $\mathrm{ug} / \mathrm{I}$ \\
\hline & $12 / 01 / 92$ & В07M03 & $\mathbf{N}$ & Chromium & & 90.00 & 53.70 & $\mathrm{ug} / \mathrm{L}$ \\
\hline & & & & Nitrate & & 900.00 & 507.00 & $u g / L$ \\
\hline & & & & Technetium-99 & & $2.06 \mathrm{U}$ & 2.48 & $\mathrm{pCi} / \mathrm{L}$ \\
\hline & & B07M07 & $\mathbf{Y}$ & Chromium & & $20.00 \mathrm{U}$ & & $\mathrm{ug} / \mathrm{L}$ \\
\hline & $3 / 09 / 93$ & 308850 & $\mathbf{N}$ & Chromium & & 320.00 & 71.60 & $\mathrm{ug} / \mathrm{I}$ \\
\hline
\end{tabular}




\section{Data Table 2. (contd)}

\section{GeoDAT Report - 3/08/99}

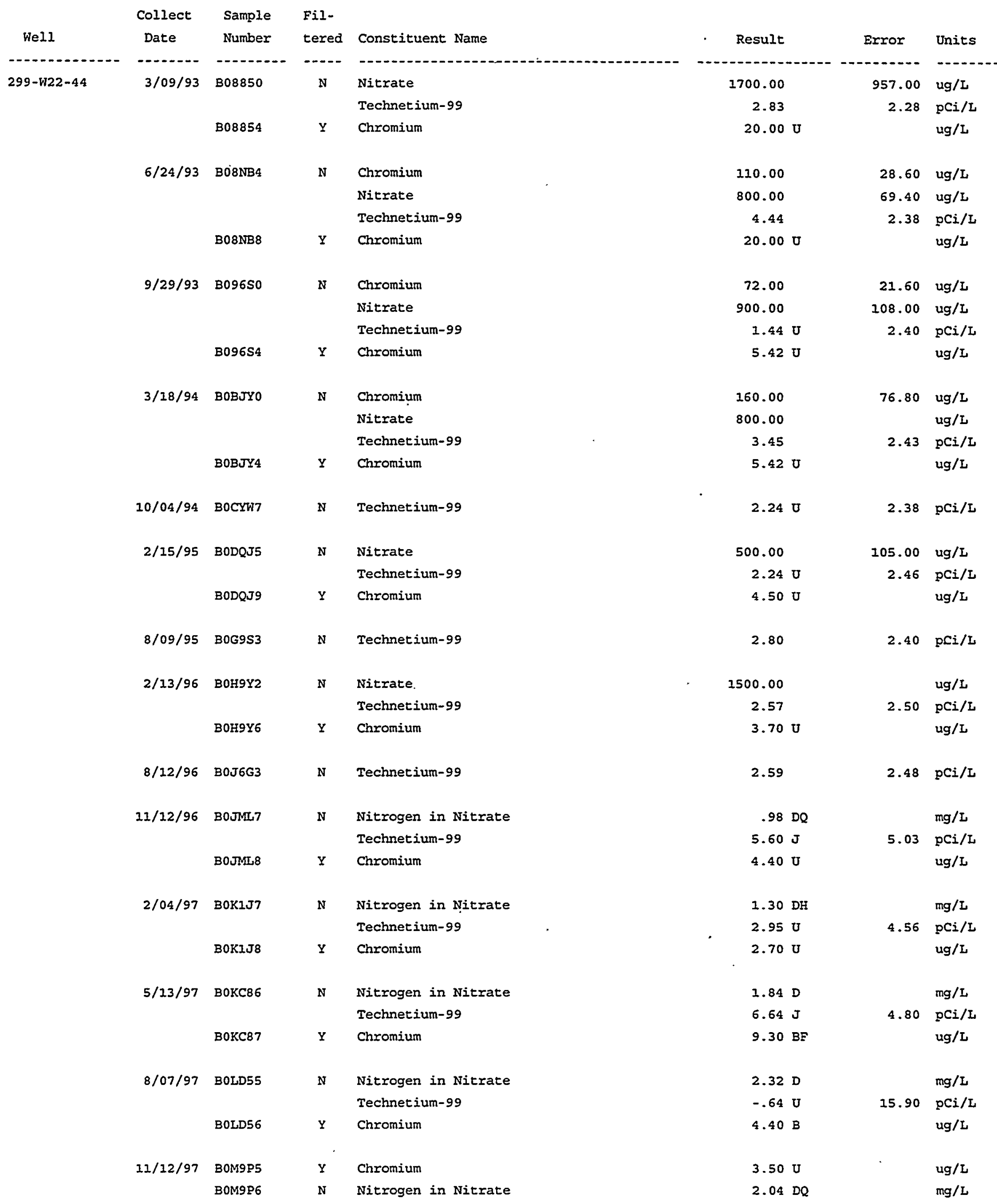


Data Table 2. (contd)

$\overline{\text { GeoDAT Report - 3/08/99 }}$

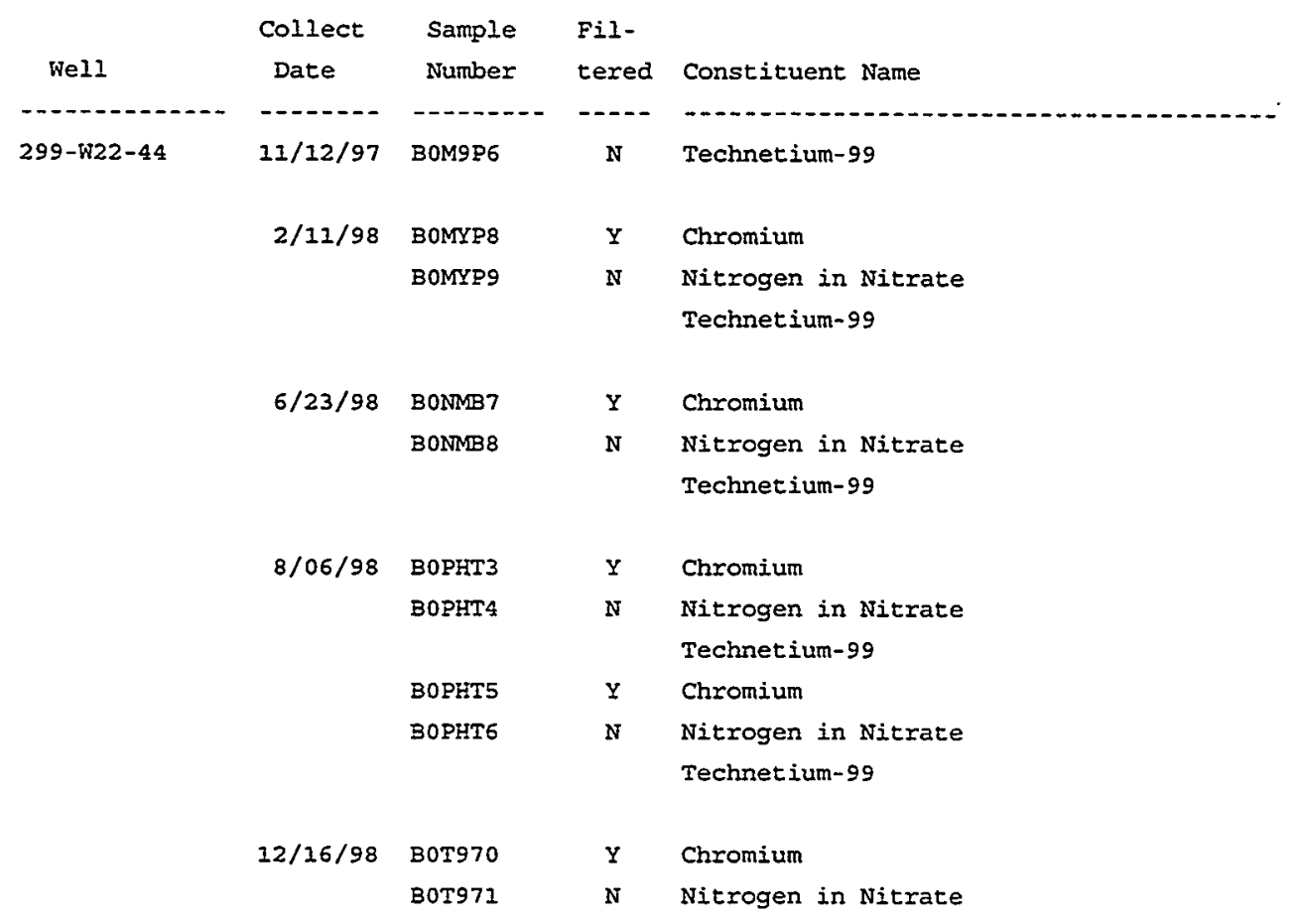

$\begin{array}{ccl}\text { Result } & \text { Error } & \text { Units } \\ 2.16 \mathrm{U} & 16.60 & \mathrm{pCi} / \mathrm{L} \\ 4.20 \mathrm{U} & & \mathrm{ug} / \mathrm{L} \\ 2.58 \mathrm{D} & & \mathrm{mg} / \mathrm{L} \\ 6.59 \mathrm{U} & 17.40 & \mathrm{pCi} / \mathrm{L} \\ & & \\ 4.90 \mathrm{~B} & & \mathrm{ug} / \mathrm{L} \\ 3.48 \mathrm{D} & & \mathrm{mg} / \mathrm{L} \\ 4.59 \mathrm{U} & 16.60 & \mathrm{pCi} / \mathrm{L} \\ & & \\ 103.00 \mathrm{~F} & & \mathrm{ug} / \mathrm{L} \\ 3.86 \mathrm{D} & & \mathrm{mg} / \mathrm{L} \\ 1.97 \mathrm{U} & 15.40 & \mathrm{pCi} / \mathrm{L} \\ 4.30 \mathrm{~B} & & \mathrm{ug} / \mathrm{L} \\ 4.01 \mathrm{D} & & \mathrm{mg} / \mathrm{L} \\ 6.63 \mathrm{U} & 15.80 & \mathrm{pCi} / \mathrm{L} \\ & & \\ 3.00 \mathrm{~B} & & \mathrm{ug} / \mathrm{L} \\ 4.60 \mathrm{D} & & \mathrm{mg} / \mathrm{L}\end{array}$

N

Chromium

Nitrate

Technetium-99

B07M12 Y Chromium

$4 / 05 / 93 \quad 308855$

$\mathbf{N}$

Chromium

Nitrate

Technetium-99

B08859

$6 / 24 / 93$ B08NO4

$\mathrm{Y}$

Chromium

N

Chromium

Nitrate

Technetium-99

B08N08

9/29/93 B09655

$y$

Chromium

N

Chromium .

Nitrace

Technetium-99

B096S6

N

Chromium

Nitrate

Technetium-99

B096T3

B096T4

$Y$

Chromium

$Y$

Chromium

$3 / 22 / 94 \quad$ BOBJY5

N

Chromium

Nitrate

Technetium-99

B0BJY9

$\mathrm{Y}$

Chromium

9/20/94 BOCYXI

N Technetium-99

\begin{tabular}{|c|c|c|}
\hline 30.00 & 17.90 & ug/L \\
\hline 4100.00 & 2310.00 & ug/L \\
\hline 14.40 & 3.54 & $\mathrm{pCi} / \mathrm{L}$ \\
\hline $20.00 \mathrm{U}$ & & $u g / L$ \\
\hline $20.00 \mathrm{U}$ & & $u g / L$ \\
\hline 6200.00 & 538.00 & $u g / L$ \\
\hline-.290 & 2.45 & $\mathrm{pCi} / \mathrm{L}$ \\
\hline $20.00 \mathrm{U}$ & & $u g / L$ \\
\hline 24.00 & 6.24 & ug $/ \mathrm{L}$ \\
\hline 9500.00 & 824.00 & $u g / L$ \\
\hline 5.13 & 2.44 & $\mathrm{pCi} / \mathrm{L}$ \\
\hline $20.00 \mathrm{U}$ & & $\mathrm{ug} / \mathrm{L}$ \\
\hline 20.00 & 6.00 & $u g / L$ \\
\hline 9400.00 & 1130.00 & $. u g / L$ \\
\hline 3.18 & 2.54 & $\mathrm{pCi} / \mathrm{L}$ \\
\hline 23.00 & 6.90 & $\mathrm{ug} / \mathrm{L}$ \\
\hline 9000.00 & 1080.00 & $u g / L$ \\
\hline 3.26 & 2.55 & $\mathrm{pCi} / \mathrm{L}$ \\
\hline $5.42 \mathrm{U}$ & & ug $/ \mathrm{L}$ \\
\hline $5.42 \mathrm{U}$ & & $u g / L$ \\
\hline $17.00 \mathrm{~L}$ & 8.16 & ug $/ \mathrm{L}$ \\
\hline $11000.00 \mathrm{D}$ & & $\mathrm{ug} / \mathrm{L}$ \\
\hline 4.95 & 2.56 & $\mathrm{pCi} / \mathrm{L}$ \\
\hline $11.00 \mathrm{U}$ & & ug/L \\
\hline 5.13 & 2.52 & $\mathrm{pCi} / \mathrm{L}$ \\
\hline
\end{tabular}


Data Table 2. (contd)

GeODAT Report - 3/08/99

\begin{tabular}{|c|c|c|c|c|c|c|c|c|}
\hline Well & $\begin{array}{l}\text { Collect } \\
\text { Date }\end{array}$ & $\begin{array}{l}\text { Sample } \\
\text { Number }\end{array}$ & $\begin{array}{l}\text { Fil- } \\
\text { tered }\end{array}$ & Constituent Name & & Result & Error & Units \\
\hline$-2-1-2-1-2-1$ & $\cdots-n$ & $\cdots+-1$ & $-\cdots$ & -10 & - & - & (n) & $-\cdots$ \\
\hline \multirow[t]{34}{*}{$299-\$ 22-45$} & $2 / 15 / 95$ & BODQKO & $\mathbf{N}$ & Nitrate & & $13000.00 \mathrm{D}$ & 2730.00 & $\mathrm{ug} / \mathrm{L}$ \\
\hline & & & & Technetium-99 & & 5.48 & 2.73 & $\mathrm{pCi} / \mathrm{L}$ \\
\hline & & BODQK4 & $Y$ & Chromium & & $4.50 \mathrm{U}$ & & $\mathrm{ug} / \mathrm{L}$ \\
\hline & $8 / 09 / 95$ & BOG9Vo & $\mathrm{N}$ & Technetium-99 & & 8.76 & 2.91 & $\mathrm{pCi} / \mathrm{L}$ \\
\hline & $2 / 13 / 96$ & Вон927 & $\mathbf{N}$ & Nitrate & & $27000.00 \mathrm{D}$ & & $\mathrm{ug} / \mathrm{L}$ \\
\hline & & & & Technetium-99 & . & 15.20 & 3.61 & $\mathrm{pCi} / \mathrm{L}$ \\
\hline & & BOFBOI & $\mathbf{Y}$ & Chromium & & $3.70 \mathrm{U}$ & & ug/L \\
\hline & $8 / 14 / 96$ & B0J6G7 & $\mathrm{N}$ & Technetium-99 & & 2.90 & 2.45 & $\mathrm{pCi} / \mathrm{L}$ \\
\hline & $11 / 12 / 96$ & BOJML9 & N & Nitrogen in Nitrate & & $5.05 \mathrm{DQ}$ & & $\mathrm{mg} / \mathrm{I}$ \\
\hline & & & & Technetium-99 & & 47.90 & 8.99 & $\mathrm{pCi} / \mathrm{L}$ \\
\hline & & BOJMMO & $\mathbf{Y}$ & Chromium & & $5.10 \mathrm{~B}$ & & $\mathrm{ug} / \mathrm{L}$ \\
\hline & $2 / 04 / 97$ & B0K1J9 & $\mathrm{N}$ & Nitrogen in Nitrate & & $5.79 \mathrm{DH}$ & & $\mathrm{mg} / \mathrm{L}$ \\
\hline & - & & & Technetium-99 & & 80.10 & 12.10 & $\mathrm{pCi} / \mathrm{L}$ \\
\hline & & BOKIKO & $\mathrm{Y}$ & Chromium & & $2.70 \mathrm{U}$ & & ug/L \\
\hline & $5 / 20 / 97$ & B0КC88 & $\mathrm{N}$ & Nitrogen in Nitrate & & $6.28 \mathrm{D}$ & & $\mathrm{mg} / \mathrm{L}$ \\
\hline & & & & Technetium-99 & & 140.00 & 18.50 & $\mathrm{pCi} / \mathrm{L}$ \\
\hline & & B0KC89 & $\mathbf{Y}$ & Chromium & & 11.50 & & $u g / L$ \\
\hline & $8 / 06 / 97$ & B0ID58 & $\mathrm{N}$ & Nitrogen in Nitrate & & $7.15 \mathrm{D}$ & & $\mathrm{mg} / \mathrm{L}$ \\
\hline & & & & Technetium-99 & & 211.00 & 35.70 & $\mathrm{pCi} / \mathrm{L}$ \\
\hline & & B0LD59 & $\mathbf{Y}$ & Chromium & & $4.40 \mathrm{~B}$ & & $\mathrm{ug} / \mathrm{L}$ \\
\hline & $11 / 11 / 97$ & BOM9P7 & $\mathbf{y}$ & Chromium & " & $6.00 \mathrm{~B}$ & & $\mathrm{ug} / \mathrm{L}$ \\
\hline & & В0M9P8 & $\mathrm{N}$ & Nitrogen in Nitrate & & $7.69 \mathrm{DQ}$ & & $\mathrm{mg} / \mathrm{L}$ \\
\hline & & & & Technetium-99 & & 256.00 & 41.00 & $\mathrm{pCi} / \mathrm{L}$ \\
\hline & $2 / 09 / 98$ & BOMYRO & $\mathrm{Y}$ & Chromium & & $8.10 \mathrm{~B}$ & & ug/L \\
\hline & & BOMYRI & $\mathbf{N}$ & Nitrogen in Nitrate & & $7.70 \mathrm{D}$ & & $\mathrm{mg} / \mathrm{L}$ \\
\hline & & & & Technetium-99 & & 311.00 & 47.00 & $\mathrm{pCi} / \mathrm{L}$ \\
\hline & $5 / 12 / 98$ & BONMB9 & $\mathbf{Y}$ & Chromium & & $8.80 \mathrm{~B}$ & & $\mathrm{ug} / \mathrm{L}$ \\
\hline & & BONMCO & $\mathrm{N}$ & Technetium-99 & & 427.00 & 59.10 & $\mathrm{pCi} / \mathrm{L}$ \\
\hline & & BoNV23 & $\mathbf{N}$ & Nitrate & & $33.00 \mathrm{D}$ & & $\mathrm{mg} / \mathrm{I}$ \\
\hline & $8 / 12 / 98$ & BOPHT7 & $Y$ & Chromium & & 10.80 & & $\mathrm{ug} / \mathrm{L}$ \\
\hline & & BOPHT8 & $N$ & Nitrogen in Nitrate & & $7.87 \mathrm{D}$ & & $\mathrm{mg} / \mathrm{L}$ \\
\hline & & & & Technetium-99 & & 679.00 & 86.20 & $\mathrm{pCi} / \mathrm{L}$ \\
\hline & $12 / 15 / 98$ & Вот973 & $\mathbf{Y}$ & Chromium & . & 16.10 & & $\mathrm{ug} / \mathrm{L}$ \\
\hline & & ВоT974 & $\mathrm{N}$ & Nitrogen in Nitrate & & $8.68 \mathrm{D}$ & & $\mathrm{mg} / \mathrm{L}$ \\
\hline 299-W22-46 & $4 / 23 / 92$ & B067X0 & $\mathrm{N}$ & Chromium & & 41.00 & 24.50 & $\mathrm{ug} / \mathrm{I}$ \\
\hline & & & & Nitrate & & 22000.00 & 22400.00 & $\mathrm{ug} / \mathrm{L}$ \\
\hline
\end{tabular}




\section{Data Table 2. (contd)}

GeODAT Report - 3/08/99

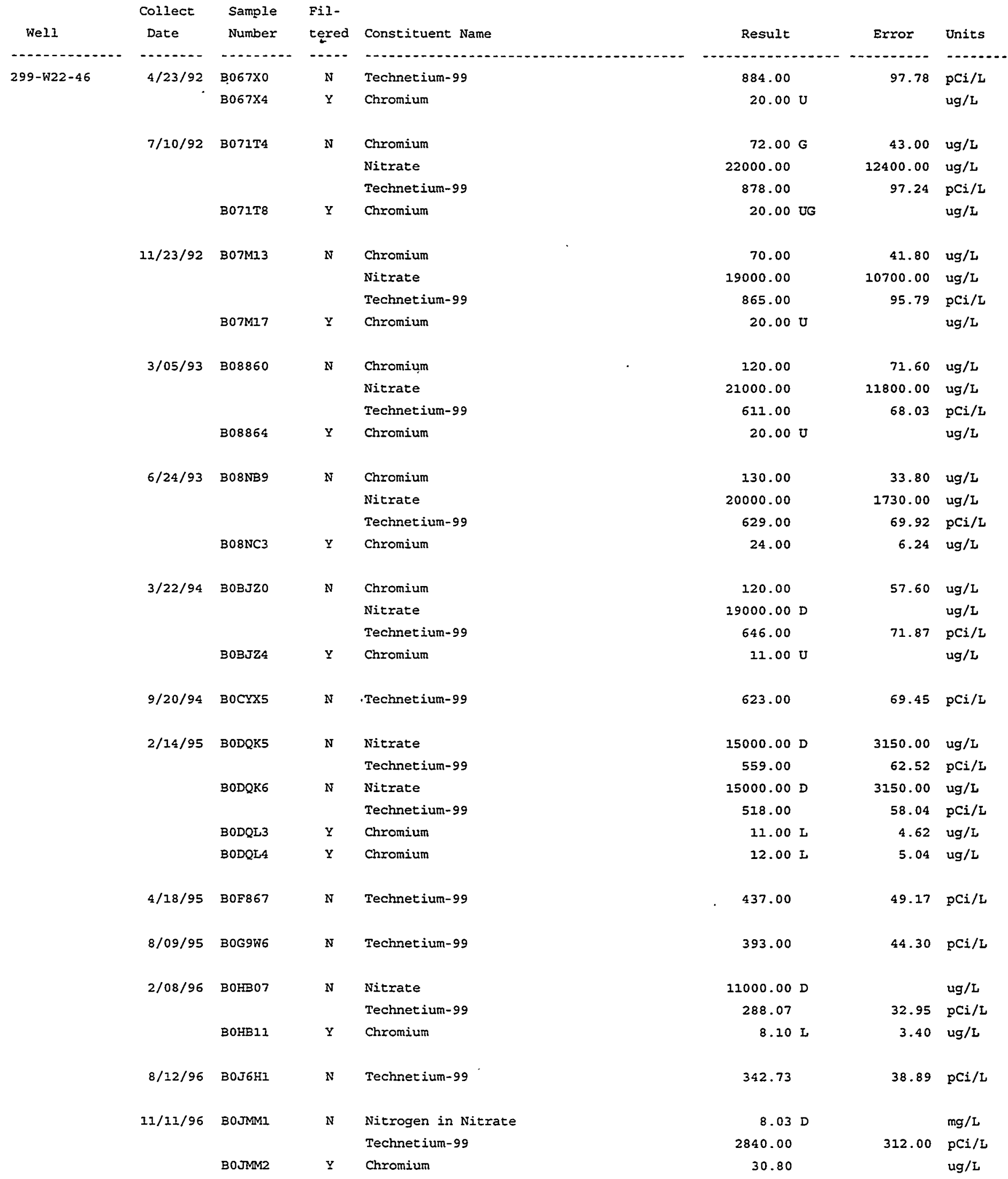




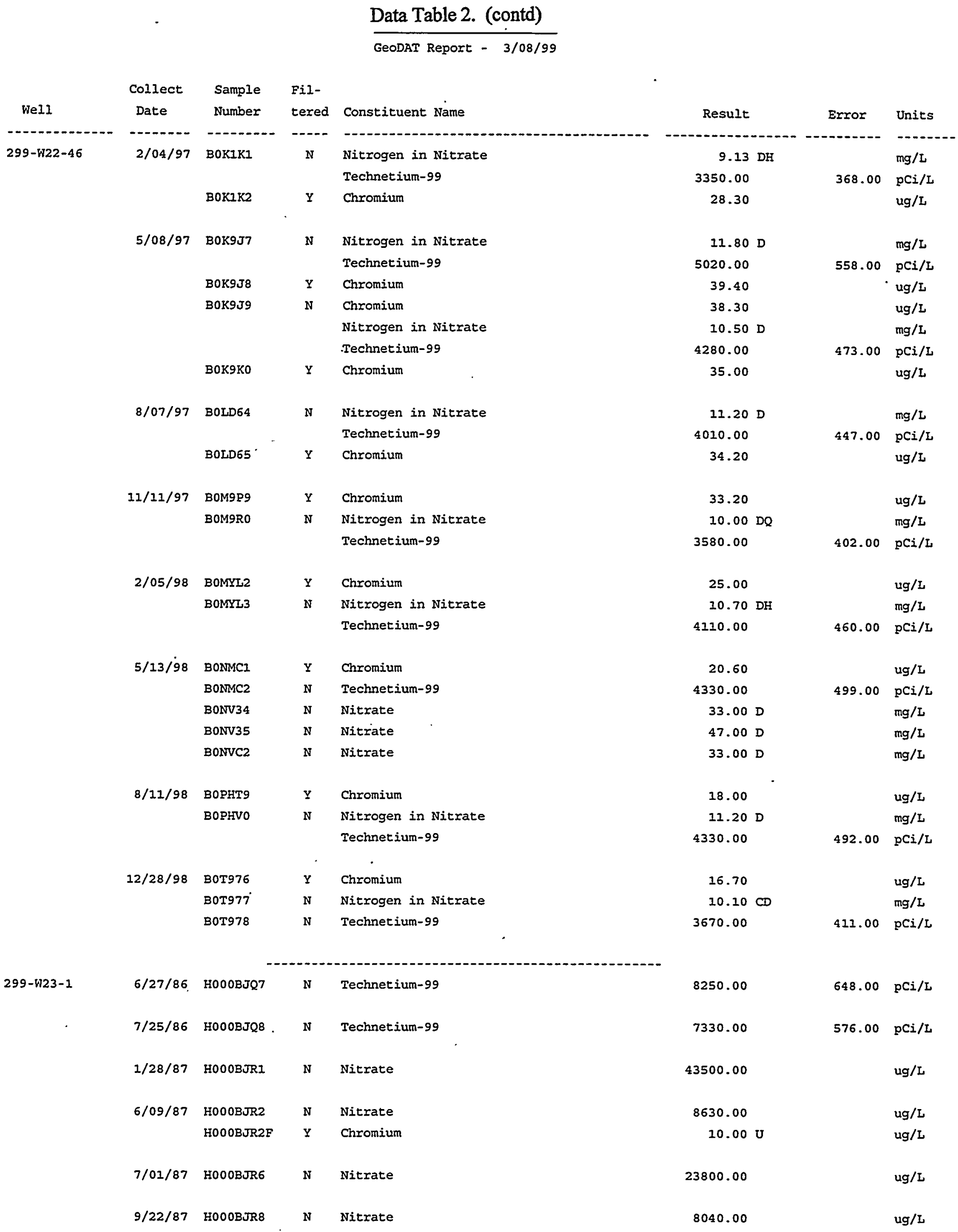


Data Table 2. (contd)

GeoDAT Report - 3/08/99

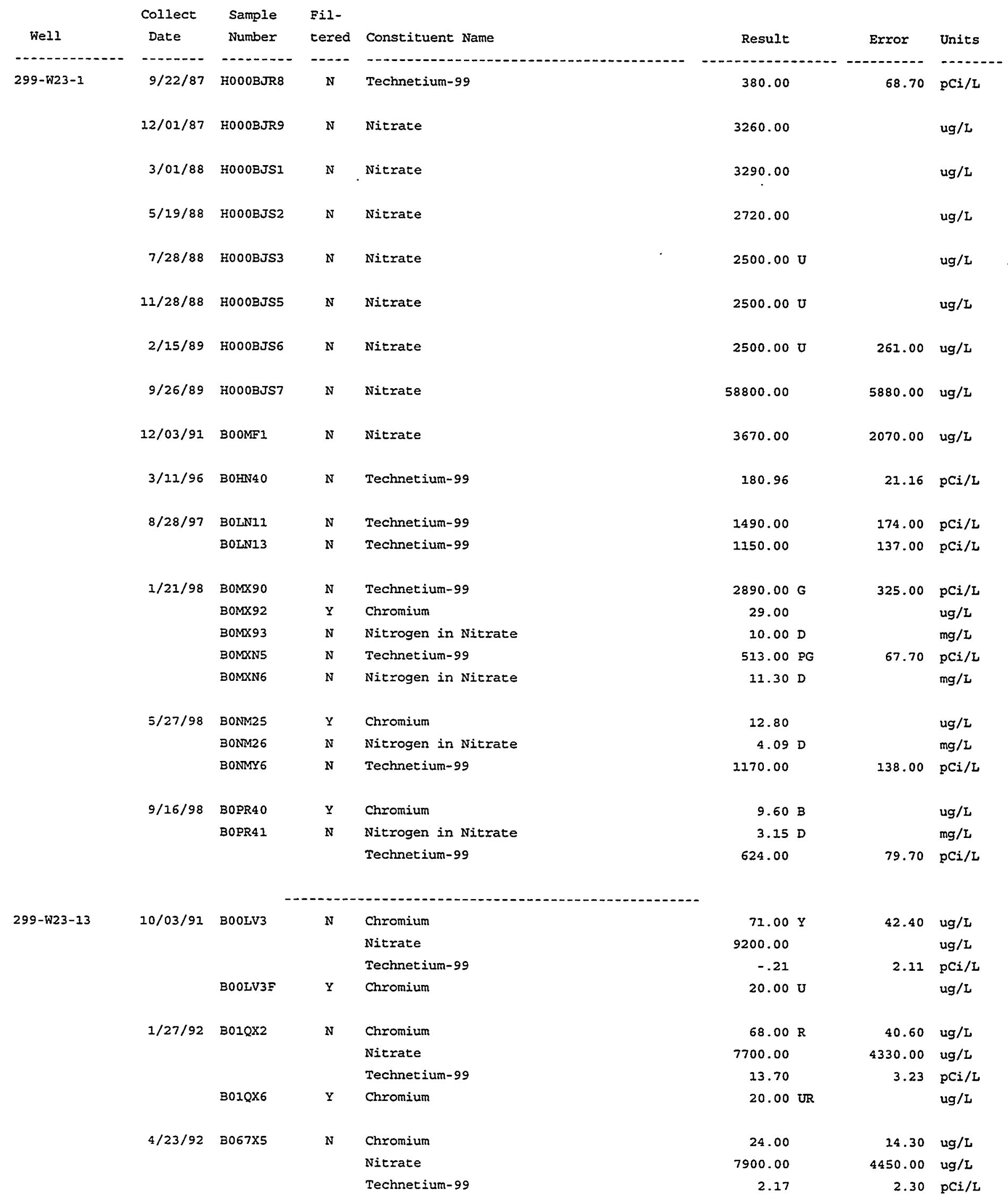




\section{Data Table 2. (contd)}

GeODAT Report - 3/08/99

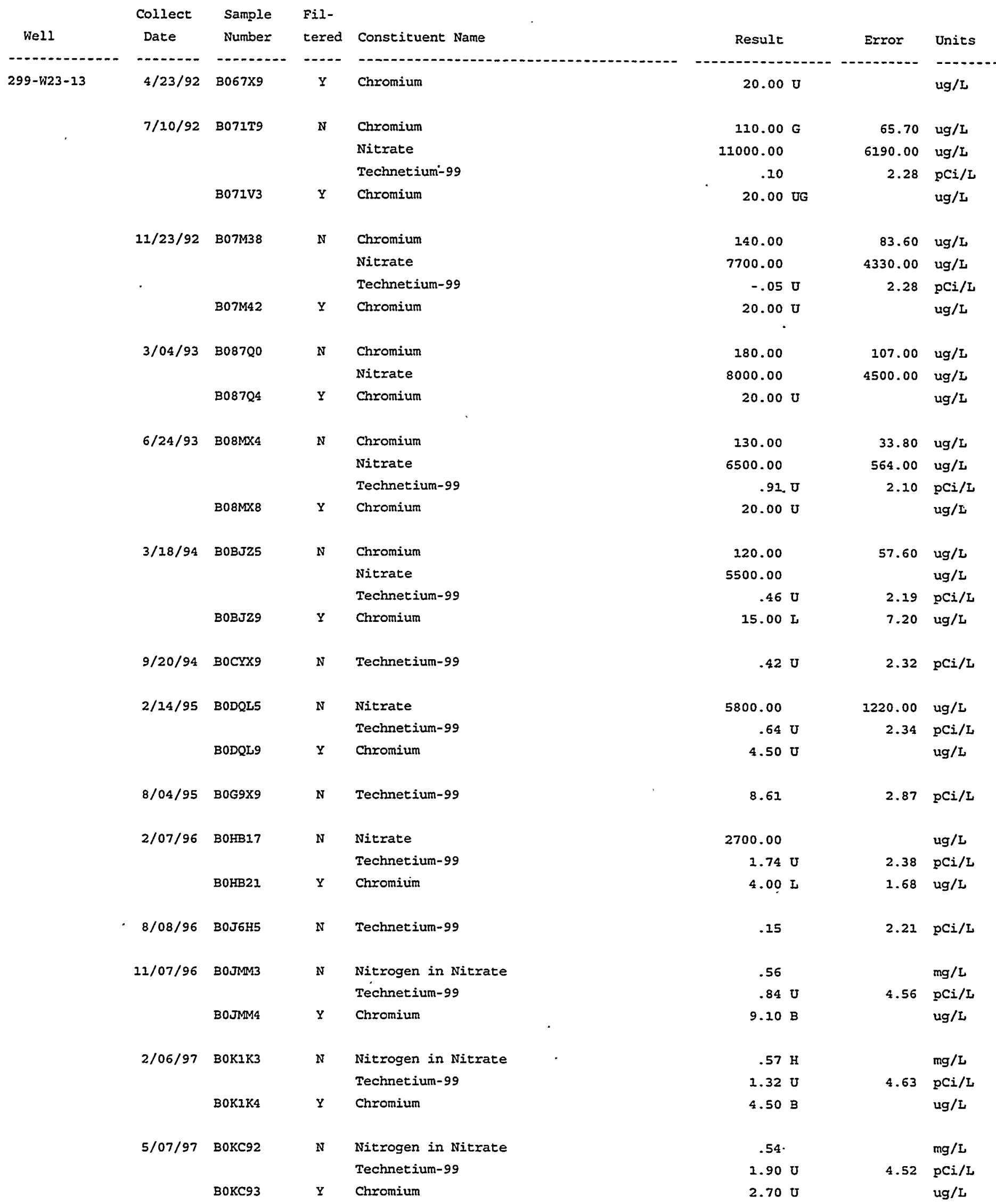




\section{Data Table 2. (contd)}

GeoDAT Report - 3/08/99

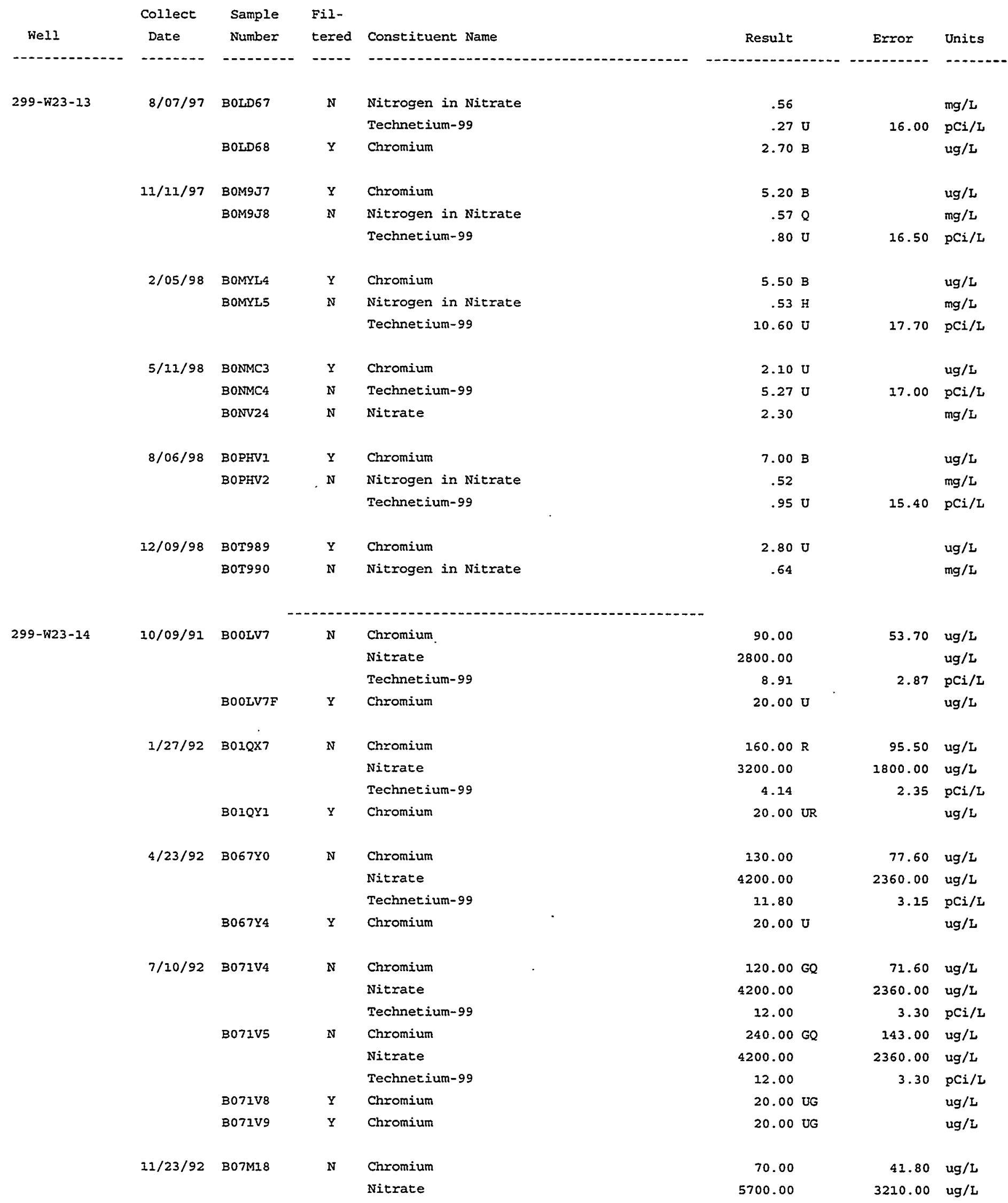




\section{Data Table 2. (contd)}

GeoDAT Report - 3/08/99

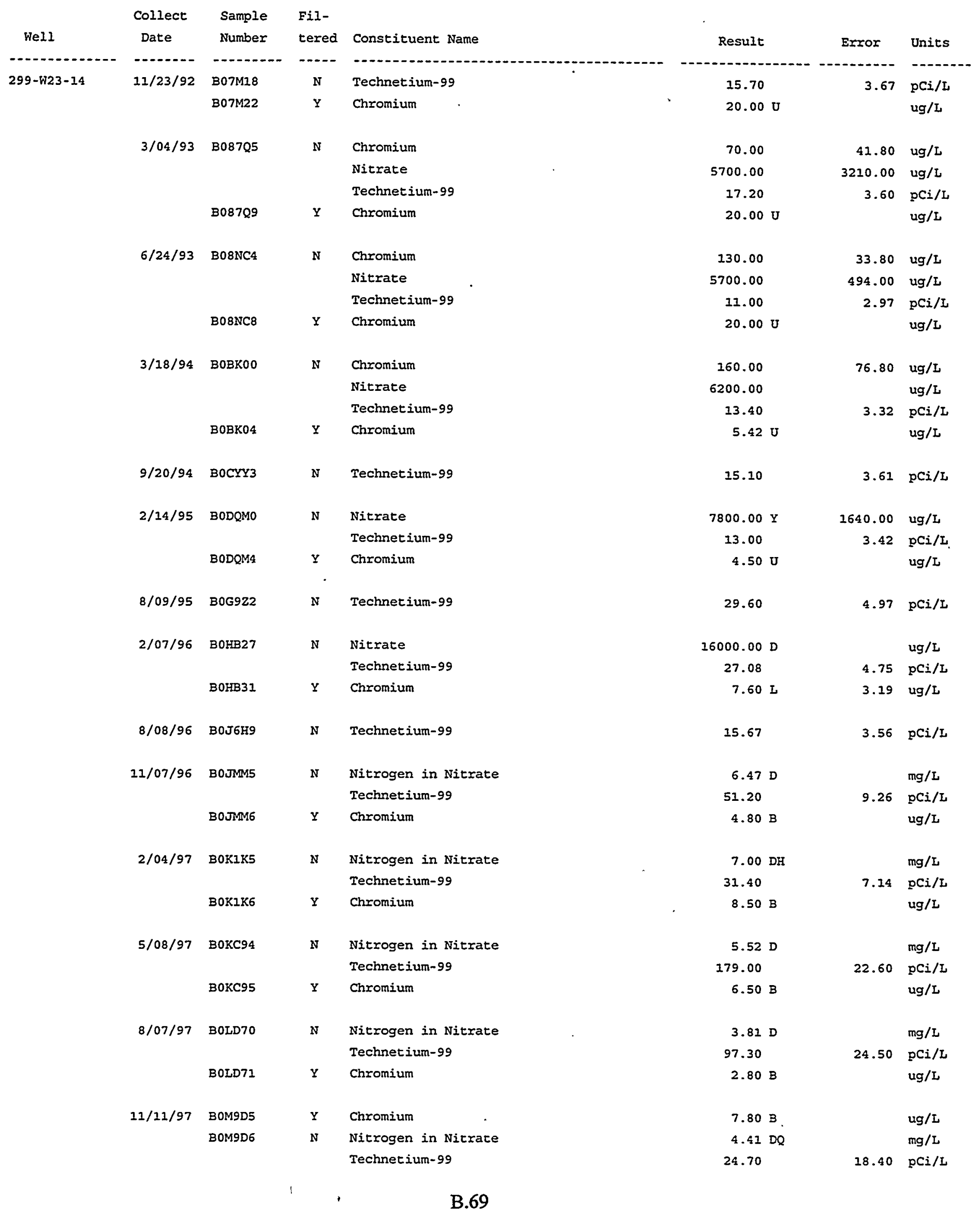


Data Table 2. (contd)

GeODAT Report - 3/08/99

\begin{tabular}{|c|c|c|c|c|c|c|c|c|}
\hline Well & $\begin{array}{l}\text { Collect } \\
\text { Date }\end{array}$ & $\begin{array}{l}\text { Sample } \\
\text { Number }\end{array}$ & $\begin{array}{l}\text { Fil- } \\
\text { tered }\end{array}$ & Constituent Name & & Result & Error & Units \\
\hline$-2-1-2-1$ & $-\cdots+-$ & $\cdots+\cdots$ & ---- & - & - & - & $n$ & $\cdots-\ldots$ \\
\hline \multirow[t]{11}{*}{$299-W 23-14$} & $2 / 05 / 98$ & BOMYC1 & $Y$ & Chromium & & $5.50 \mathrm{~B}$ & & $\mathrm{ug} / \mathrm{I}$ \\
\hline & & BOMYC2 & $\mathbf{N}$ & Nitrogen in Nitrate & & $2.63 \mathrm{DF}$ & & $\mathrm{mg} / \mathrm{L}$ \\
\hline & & & & Technetium-99 & & 27.90 & 19.10 & $\mathrm{pCi} / \mathrm{L}$ \\
\hline & $5 / 11 / 98$ & BONMC5 & $\mathbf{Y}$ & Chromium & & $5.00 \mathrm{~B}$ & & ug/L \\
\hline & & BONMC6 & $\mathrm{N}$ & Technetium-99 & & 24.20 & 18.50 & $\mathrm{pCi} / \mathrm{L}$ \\
\hline & & BONV25 & N & Nitrate & & $14.00 \mathrm{D}$ & & $\mathrm{mg} / \mathrm{L}$ \\
\hline & $8 / 06 / 98$ & BOPHV3 & $Y$ & Chromium & & 10.30 & & ug/L \\
\hline & & BOPEV4 & N & Nitrogen in Nitrate & & $5.99 \mathrm{D}$ & & $\mathrm{mg} / \mathrm{L}$ \\
\hline & & & & Technetium-99 & & 21.30 & 17.00 & $\mathrm{pCi} / \mathrm{L}$ \\
\hline & $12 / 09 / 98$ & BoT992 & $\mathrm{Y}$ & Chromium & & 12.50 & & $u g / L$ \\
\hline & & 30T993 & $\mathrm{N}$ & Nitrogen in Nitrate & & $6.83 \mathrm{D}$ & & $\mathrm{mg} / \mathrm{L}$ \\
\hline \multirow[t]{28}{*}{$299-W 23-15$} & $4 / 23 / 92$ & B067N4 & $\mathrm{N}$ & Chromium & . & 93.00 & 55.50 & ug/L \\
\hline & & & & Nitrate & & 67000.00 & 37700.00 & ug $/ \mathrm{L}$ \\
\hline & & & & Technetium-99 & & 3500.00 & 382.40 & $\mathrm{pCi} / \mathrm{L}$ \\
\hline & & B067N8 & $\mathbf{Y}$ & Chromium & & 33.00 & 19.70 & ug/L \\
\hline & $7 / 10 / 92$ & B071W0 & $\mathrm{N}$ & Chromium & & $220.00 \mathrm{G}$ & 131.00 & ug/L \\
\hline & & & & Nitrate & & 63000.00 & 35500.00 & $\mathrm{ug} / \mathrm{L}$ \\
\hline & & & & Technetium-99 & & 5220.00 & 570.20 & $\mathrm{pCi} / \mathrm{L}$ \\
\hline & & B071W4 & $\mathrm{Y}$ & Chromium & & $29.00 \mathrm{G}$ & 17.30 & $\mathrm{ug} / \mathrm{L}$ \\
\hline & $11 / 23 / 92$ & B07M23 & $\mathbf{N}$ & Chromium & & 120.00 & 71.60 & ug $/ \mathrm{L}$ \\
\hline & & & & Nitrate & & 68000.00 & 38300.00 & $u g / L$ \\
\hline & & & & Technetium-99 & & 7320.00 & 799.40 & $\mathrm{pCi} / \mathrm{L}$ \\
\hline & & B07M27 & $\mathrm{Y}$ & Chromium & & 40.00 & 23.90 & $\mathrm{ug} / \mathrm{L}$ \\
\hline & $3 / 04 / 93$ & B087SO & $\mathrm{N}$ & Chromium & & 170.00 & 101.00 & ug/L \\
\hline & & & & Nitrate & & 76000.00 & 42800.00 & $\mathrm{ug} / \mathrm{L}$ \\
\hline & & & & Technetium-99 & & 7740.00 & 844.80 & $\mathrm{pCi} / \mathrm{L}$ \\
\hline & & B087S4 & $Y$ & Chromium & & 40.00 & 23.90 & $u g / L$ \\
\hline & $6 / 25 / 93$ & 308NC9 & $\mathrm{N}$ & Chromium & & 130.00 & 33.80 & ug/L \\
\hline & & & & Nitrate & & 73000.00 & 6330.00 & $\mathrm{ug} / \mathrm{L}$ \\
\hline & & & & Technetium-99 & & 7040.00 & 768.90 & $\mathrm{pCi} / \mathrm{L}$ \\
\hline & & 308NDO & $\mathrm{N}$ & Chromium & & 120.00 & 31.20 & $\mathrm{ug} / \mathrm{L}$ \\
\hline & & & & Nitrate & & 73000.00 & 6330.00 & ug/L \\
\hline & & & & Technetium-99 & & 6550.00 & 714.60 & $\mathrm{pCi} / \mathrm{L}$ \\
\hline & & B08ND7 & $\mathrm{Y}$ & Chromium & & 37.00 & 9.62 & $u g / L$ \\
\hline & & B08ND8 & $Y$ & Chromium & & 47.00 & 12.20 & $\mathrm{ug} / \mathrm{L}$ \\
\hline & $3 / 18 / 94$ & B0BK05 & $\mathrm{N}$ & Chromium & & 140.00 & 67.20 & ug/L \\
\hline & & & & Nitrate & & $41000.00 \mathrm{D}$ & & $\mathrm{ug} / \mathrm{L}$ \\
\hline & & & & Technetium-99 & & 1930.00 & 211.60 & $\mathrm{pCi} / \mathrm{L}$ \\
\hline & & ВОВК09 & $\mathrm{Y}$ & Chromium & & 24.00 & 11.50 & $\mathrm{ug} / \mathrm{L}$ \\
\hline
\end{tabular}


Data Table 2. (contd)

GeODAT Report - 3/08/99

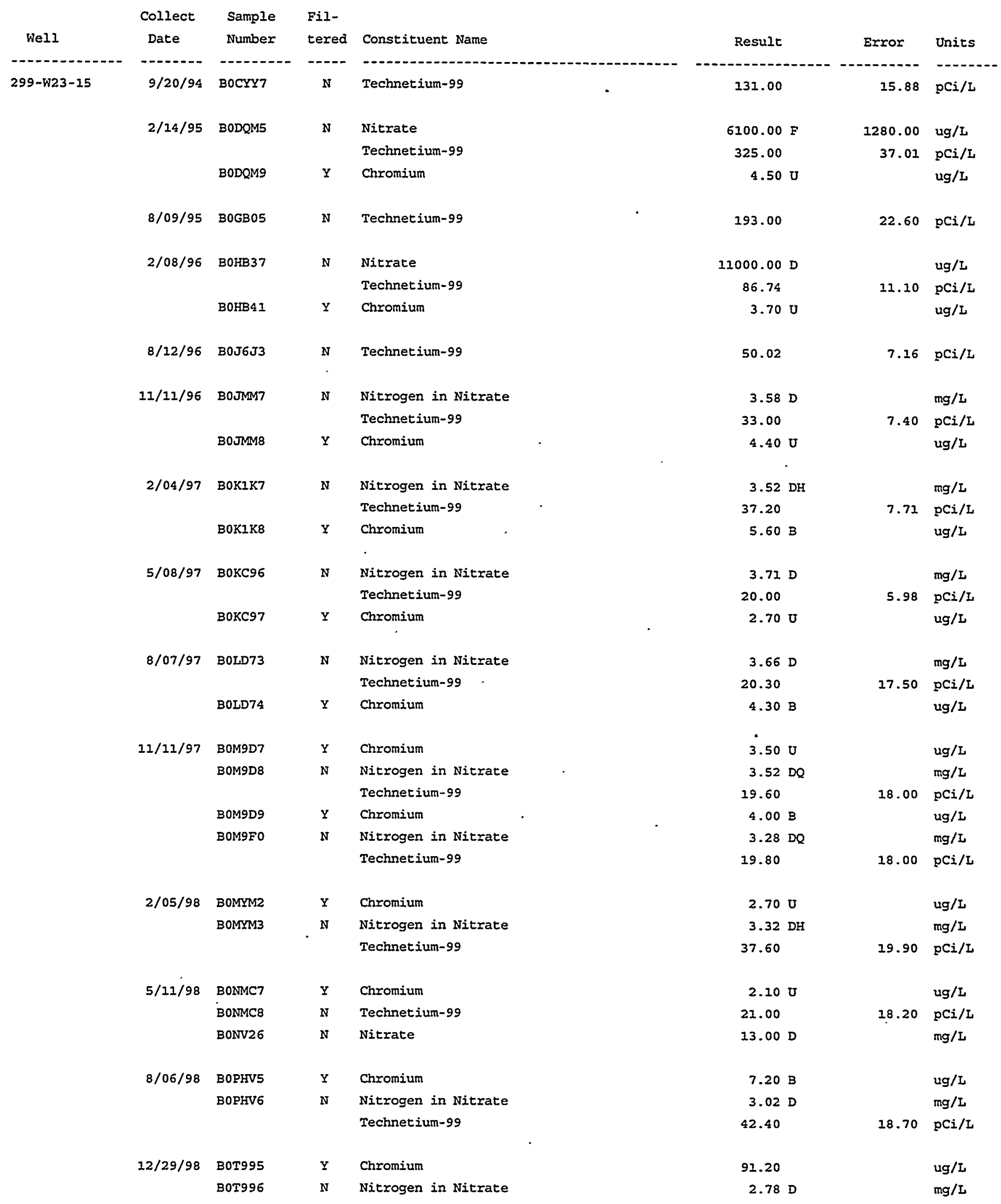

B.71 


\section{Data Table 2. (contd)}

GeoDAT Report - 3/08/99

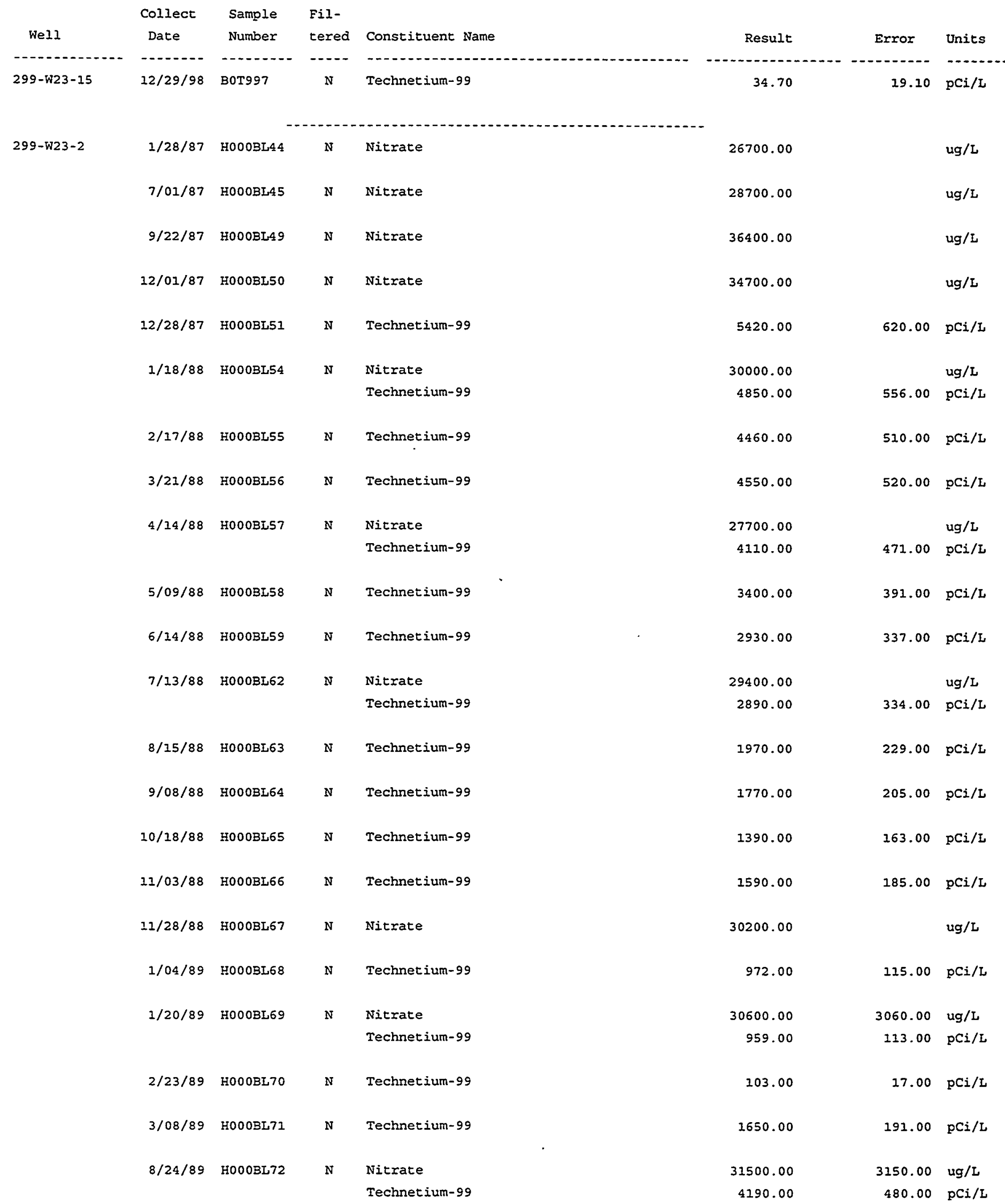




\section{Data Table 2. (contd)}

GeoDAT Report - 3/08/99

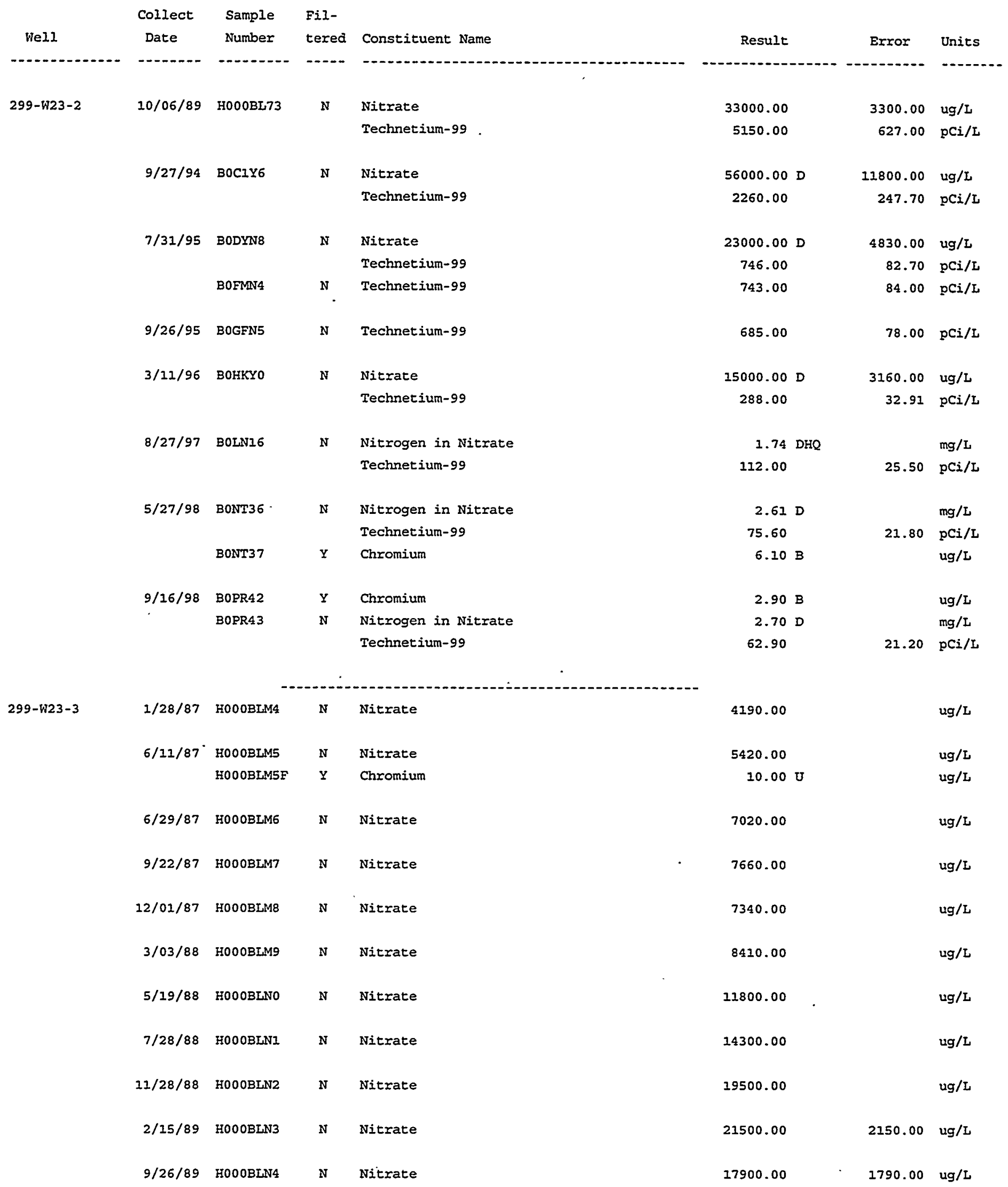




\section{Data Table 2. (contd)}

GeoDAT Report - 3/08/99

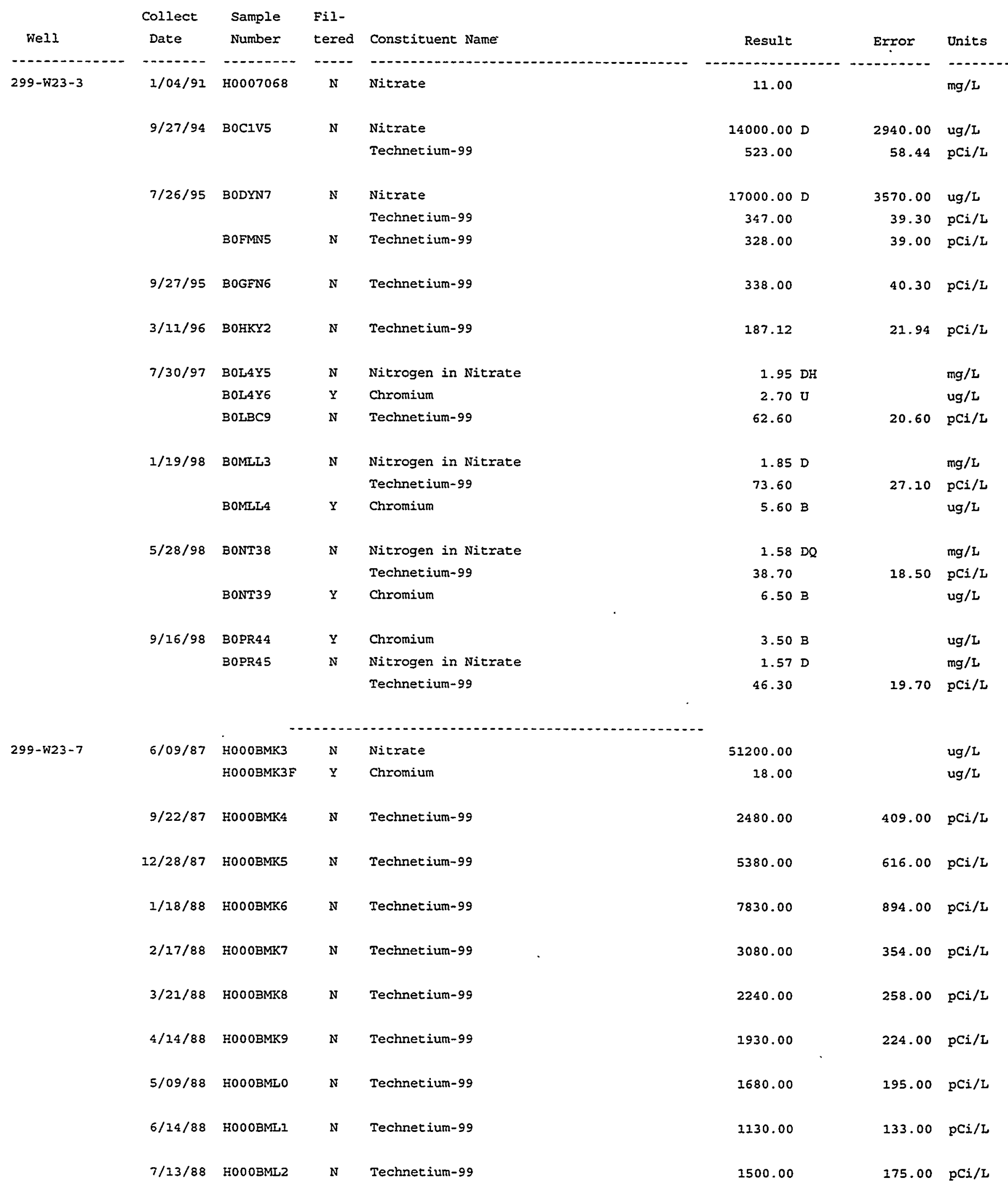




\section{Data Table 2. (contd)}

$$
\text { GeoDAT Report - 3/08/99 }
$$

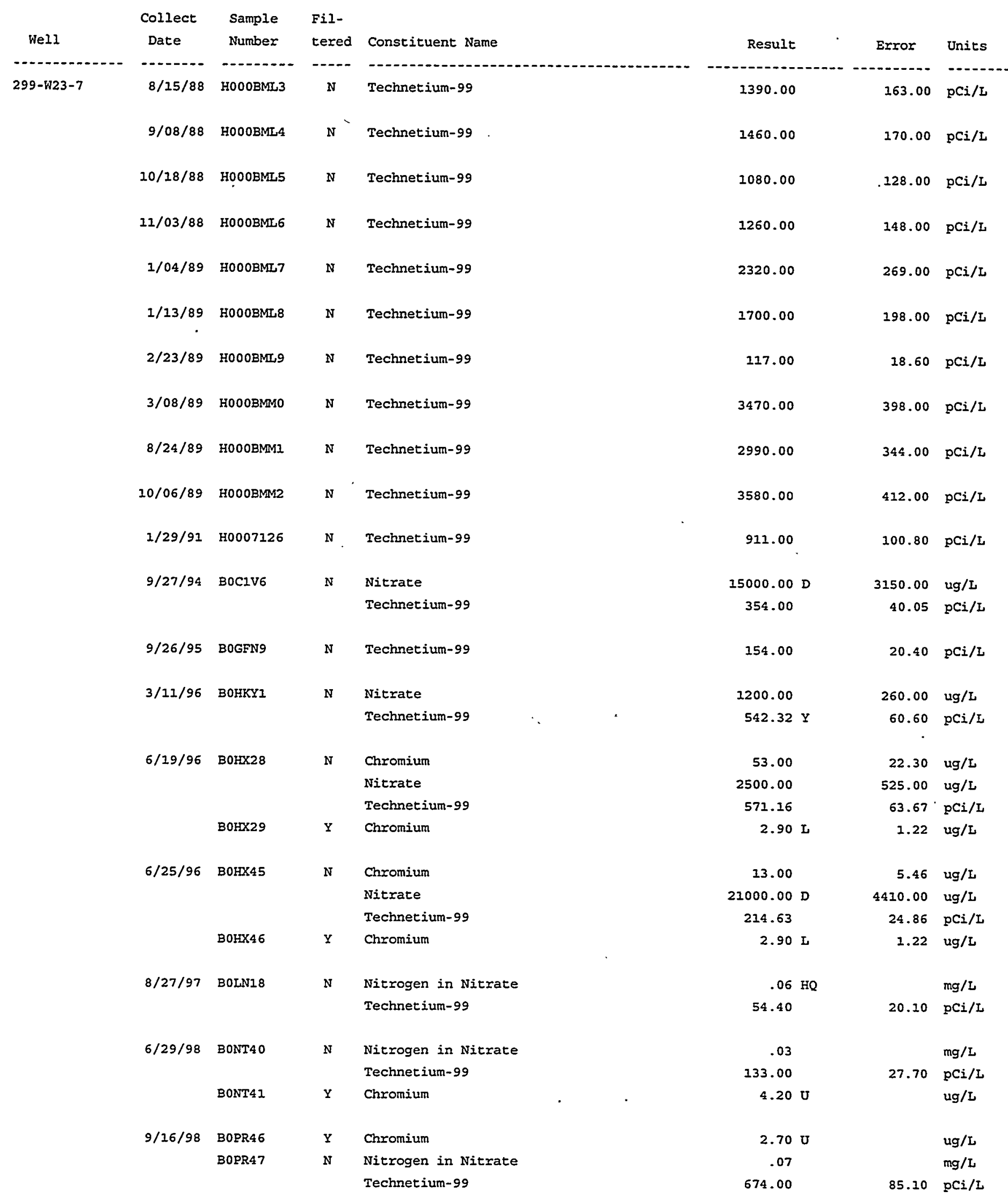


Data Table 2. (contd)

GeODAT Report - 3/08/99

Collect
Date $\quad \begin{gathered}\text { Sample } \\ \text { Number }\end{gathered}$ Fil- $\begin{aligned} & \text { tered Constituent Name } \\ & \text { Result }\end{aligned}$


Data Table 3. This table provides data in reference to comment 102.

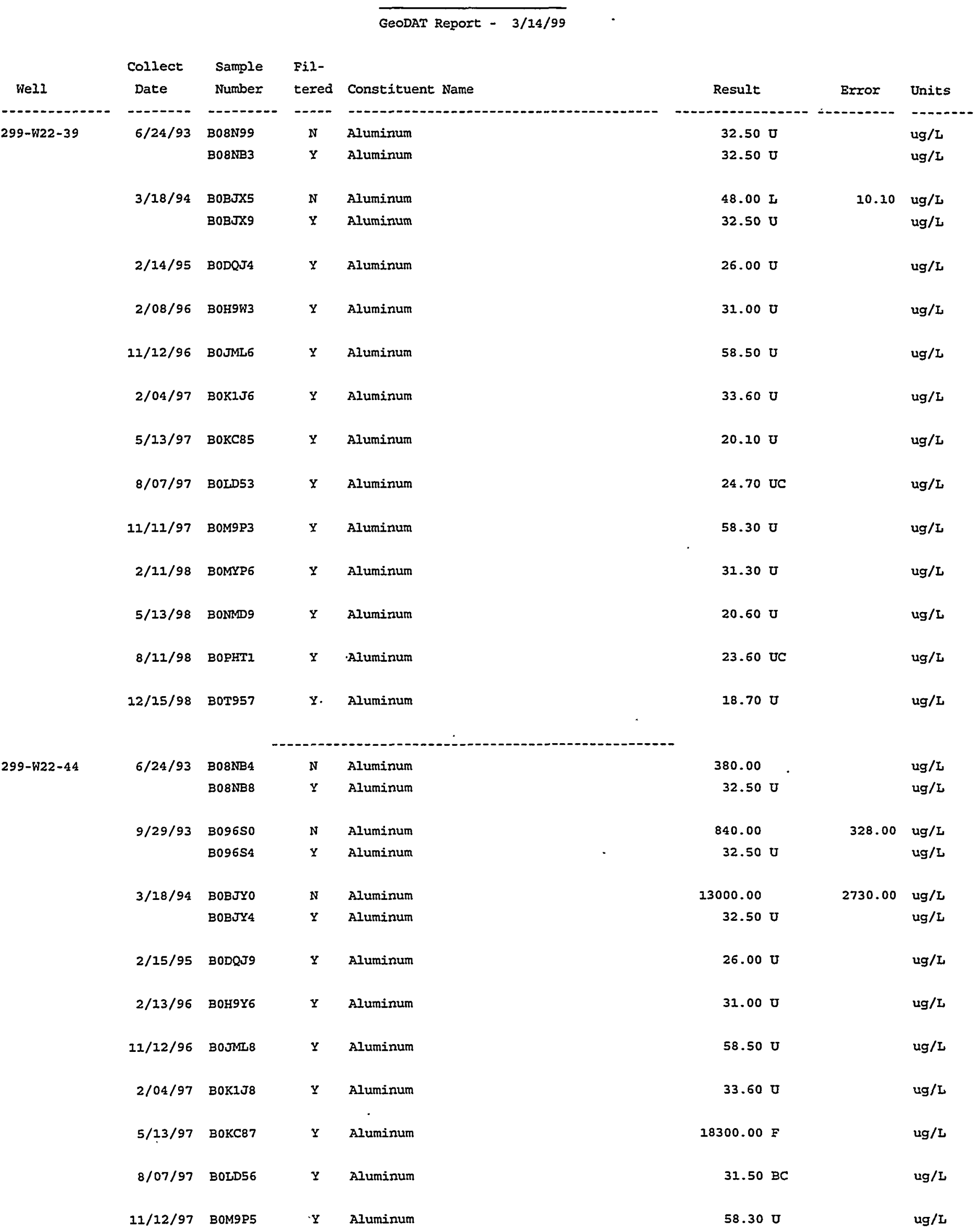




\section{Data Table 3. (contd)}

GeoDAT Report - 3/14/99

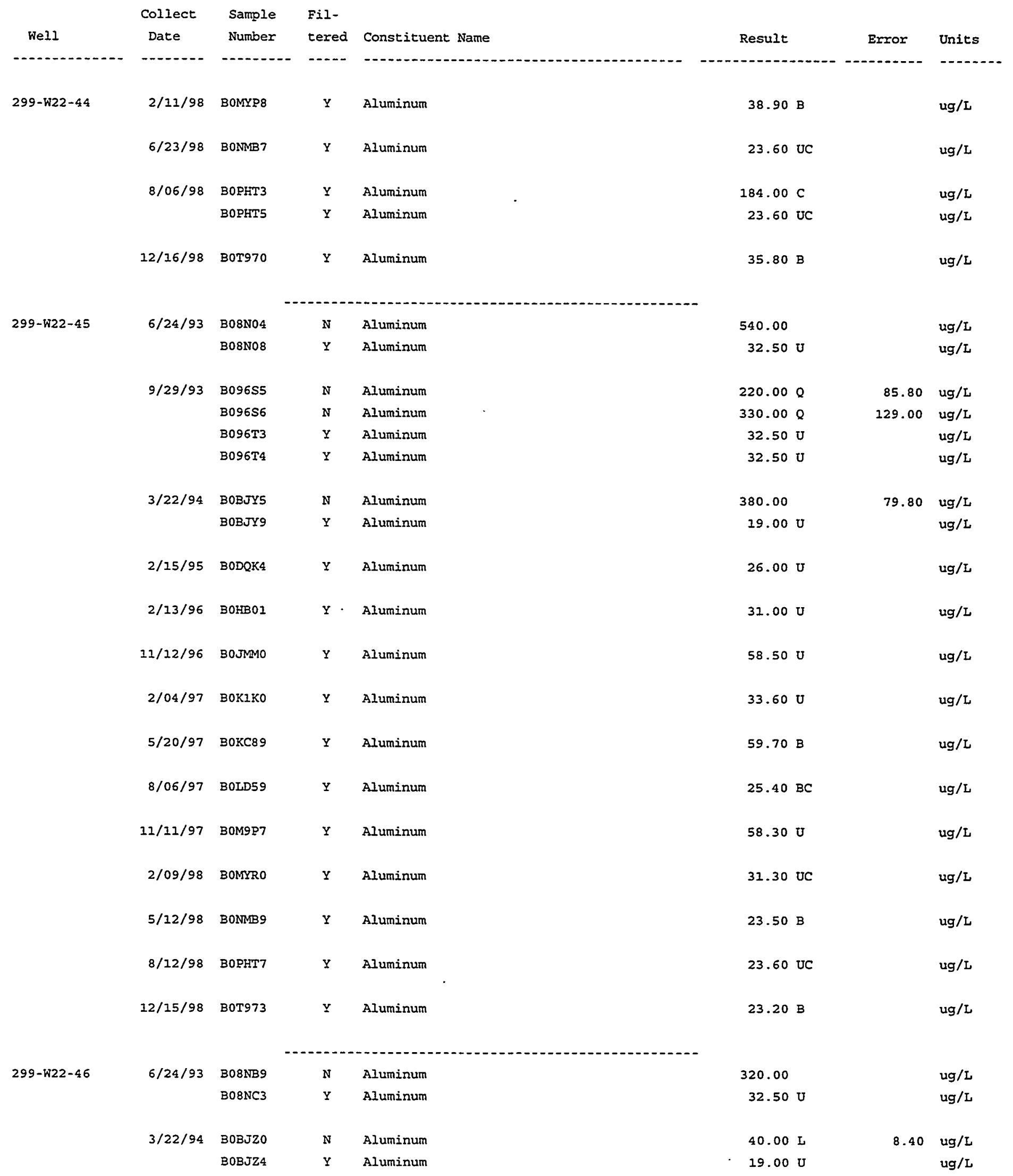


Data Table 3. (contd)

GeODAT Report - 3/14/99

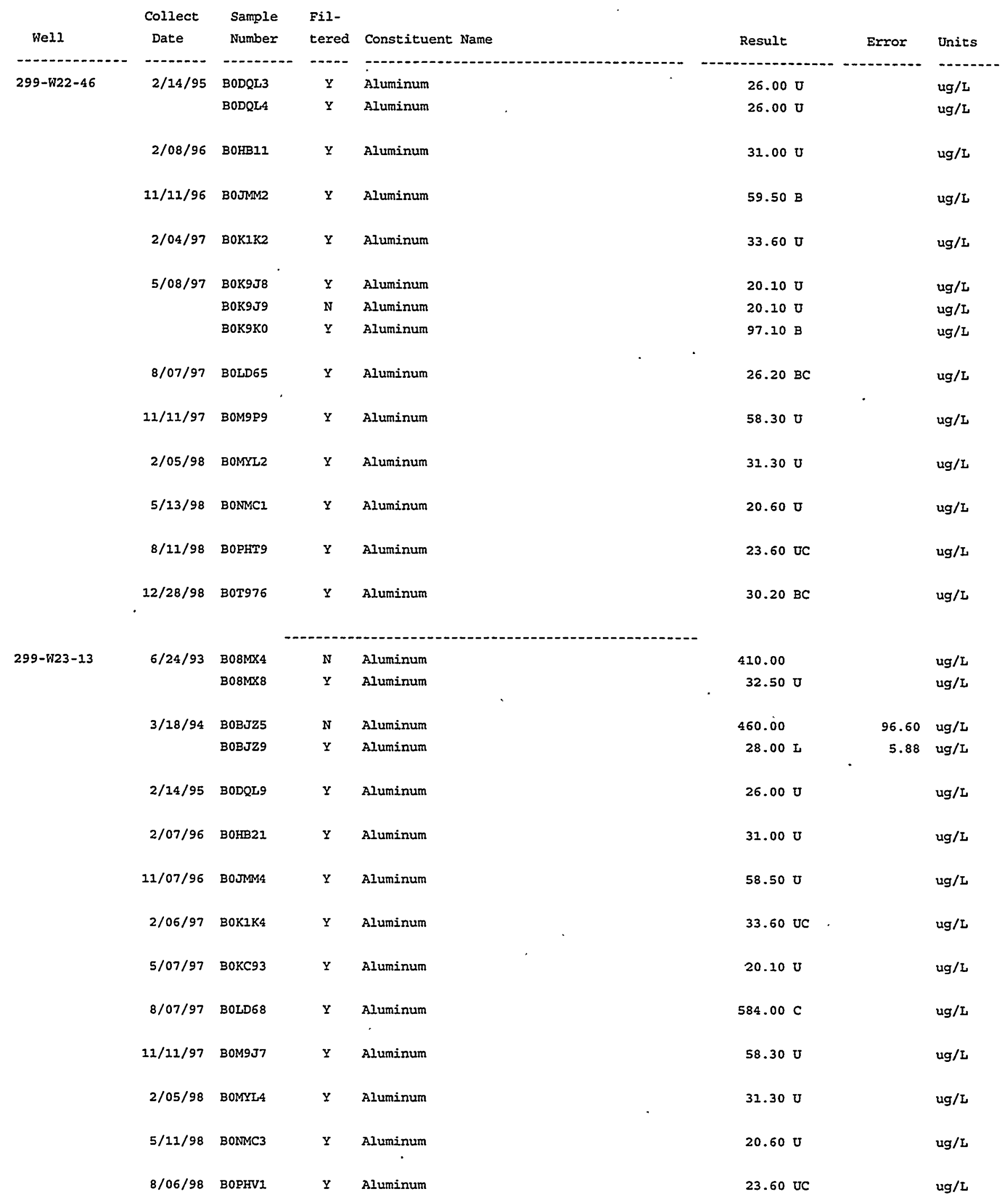


Data Table 3. (contd)

GeoDAT Report - 3/14/99

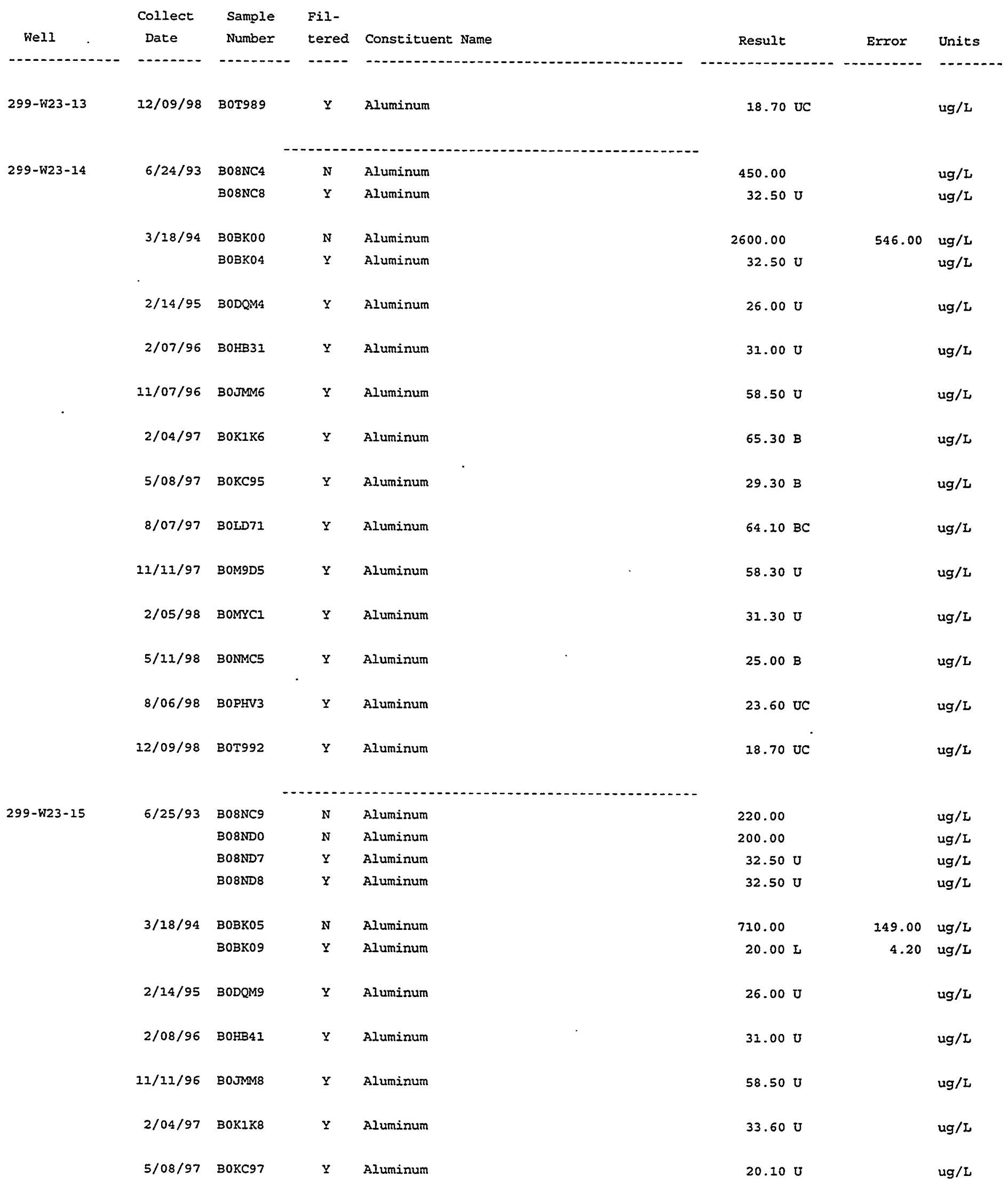




\section{Data Table 3. (contd)}

GeODAT Report - 3/14/99

\begin{tabular}{|c|c|c|c|c|c|}
\hline Well & $\begin{array}{l}\text { Collect } \\
\text { Date }\end{array}$ & $\begin{array}{l}\text { Sample } \\
\text { Number }\end{array}$ & $\begin{array}{l}\text { Fil- } \\
\text { tered }\end{array}$ & Constituent Name & \\
\hline 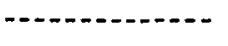 & $-\cdots \cdots$ & $--\infty-1--1$ & ---- & 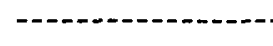 & 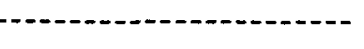 \\
\hline \multirow[t]{7}{*}{$299-W 23-15$} & $8 / 07 / 97$ & BOLD74 & $Y$ & Aluminum & \\
\hline & $21 / 11 / 97$ & BOM9D7 & $Y$ & Aluminum & \\
\hline & & BOM9D9 & $Y$ & Aluminum & \\
\hline & $2 / 05 / 98$ & BOMYM2 & $Y$ & Aluminum & \\
\hline & $5 / 11 / 98$ & BONMC7 & $Y$ & Aluminum & \\
\hline & $8 / 06 / 98$ & BOPFV5 & $\mathbf{Y}$ & Aluminum & . \\
\hline & $12 / 29 / 98$ & B0T995 & $\mathbf{Y}$ & Aluminum & - \\
\hline
\end{tabular}

$\begin{array}{lll}\text { Result } & \text { Error } & \text { Units } \\ 67.90 \mathrm{BC} & \mathrm{ug} / \mathrm{L} \\ 58.30 \mathrm{U} & \mathrm{ug} / \mathrm{L} \\ 58.30 \mathrm{U} & \mathrm{ug} / \mathrm{L} \\ 31.30 \mathrm{U} & \mathrm{ug} / \mathrm{L} \\ 30.20 \mathrm{~B} & \mathrm{ug} / \mathrm{L} \\ 23.60 \mathrm{UC} & \mathrm{ug} / \mathrm{L} \\ 150.00 \mathrm{C} & \mathrm{ug} / \mathrm{L}\end{array}$

B. 81 
Data Table 3. (contd)

GeODAT Report - 3/14/99

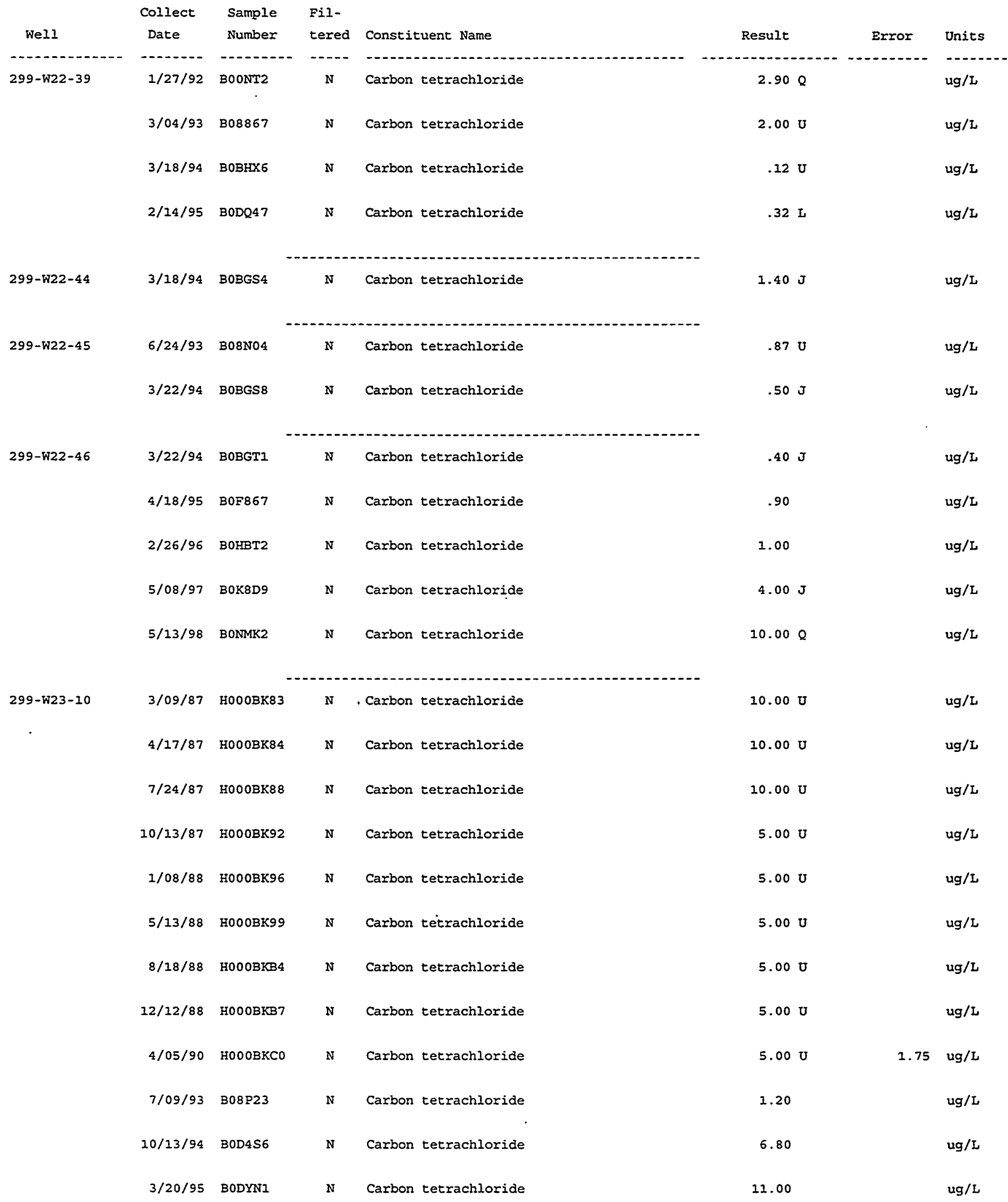

B. 82 
Data Table 3. (contd)

GeODAT Report - 3/14/99

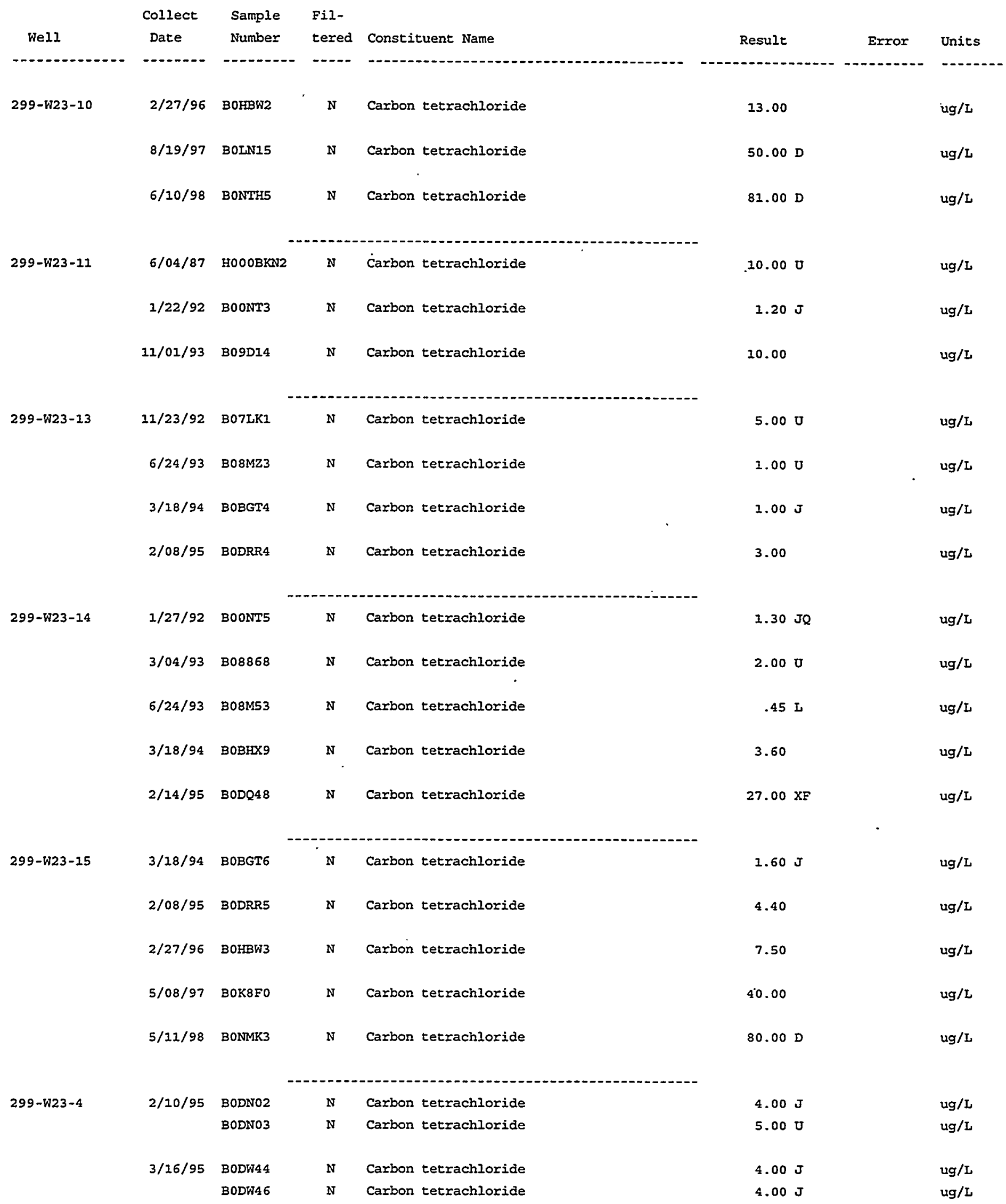


Data Table 3. (contd)

GeODAT Report - 3/14/99

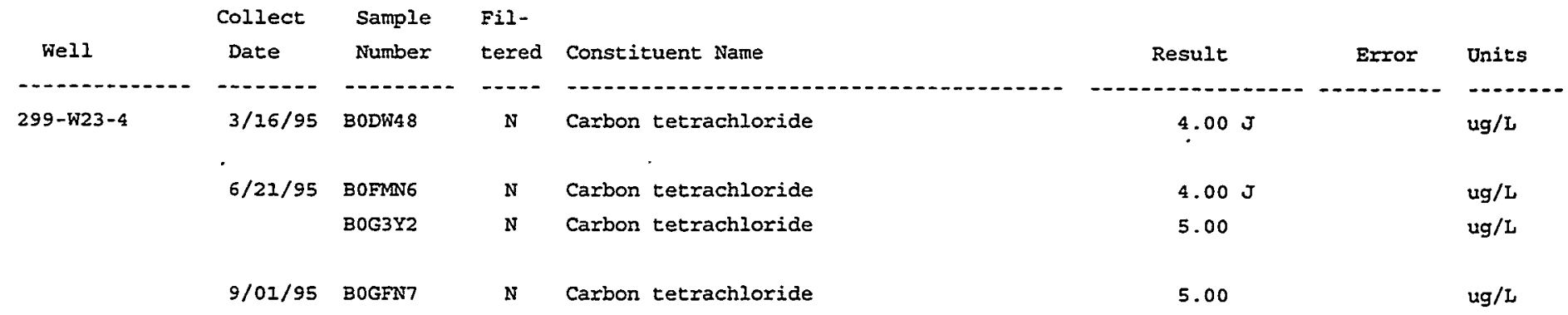


Data Table 3. (contd)

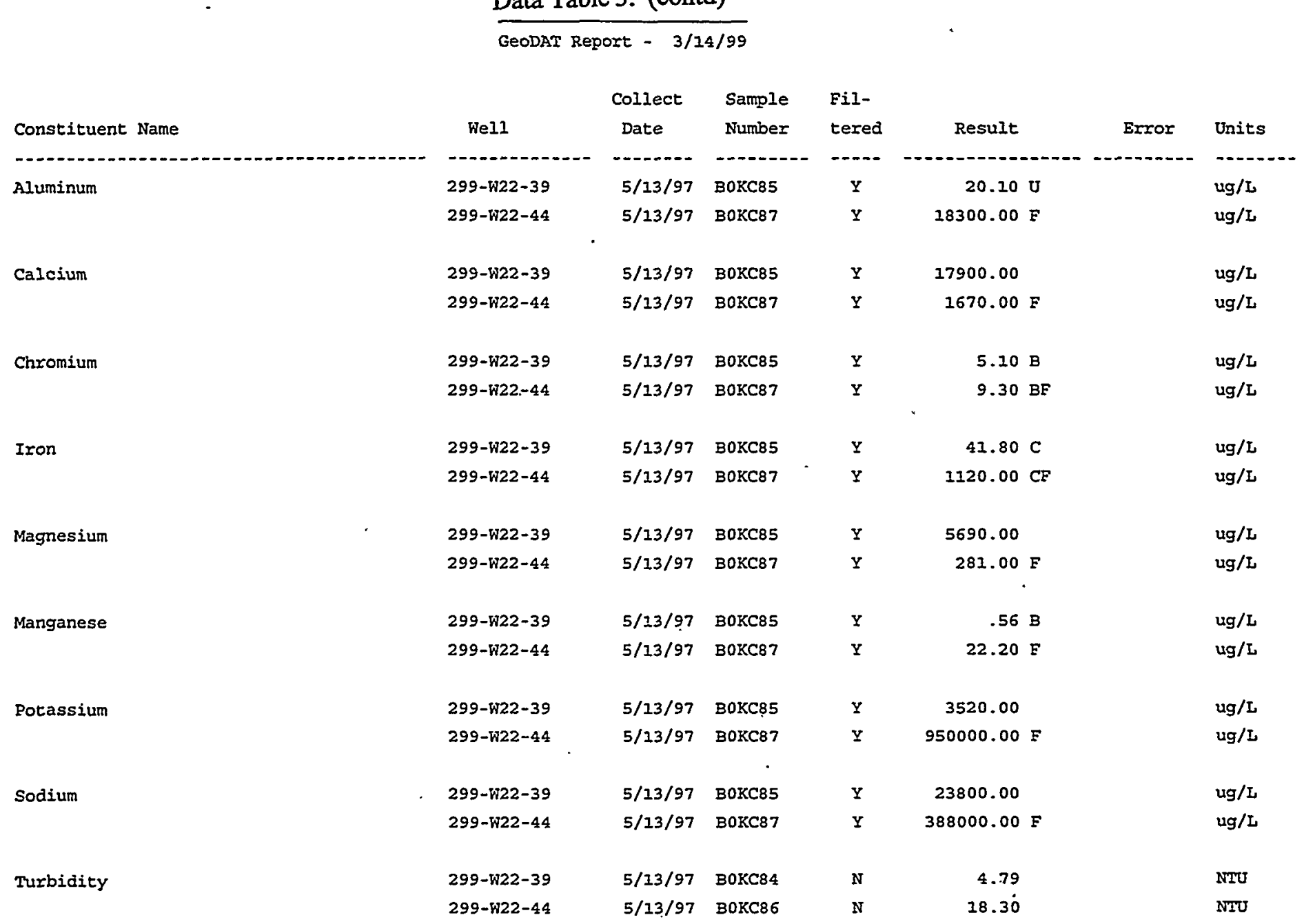




\section{Data Table 3. (contd)}

GeODAT Report - 2/09/99

\begin{tabular}{|c|c|c|c|c|c|c|c|c|}
\hline ผell & $\begin{array}{l}\text { Collect } \\
\text { Date }\end{array}$ & $\begin{array}{l}\text { Sample } \\
\text { Number }\end{array}$ & $\begin{array}{l}\text { Fil- } \\
\text { tered }\end{array}$ & Constituent Name & & Result & Exror & Units \\
\hline - & ----- & $\cdots+\cdots$ & $-\cdots$ & - - - & -....... & - & - & $-\cdots-\cdots$ \\
\hline \multirow[t]{24}{*}{$299-W 22-44$} & $9 / 09 / 92$ & B07159 & $\mathbf{N}$ & Turbidity & & 5.00 & & NTU \\
\hline & $12 / 01 / 92$ & B07M03 & $\mathrm{N}$ & Turbidity & & 3.00 & & NTU \\
\hline & $3 / 09 / 93$ & $B 08850$ & $\mathrm{~N}$ & Turbidity & & 4.20 & & NIU \\
\hline & $6 / 24 / 93$ & B08NB4 & $\mathbf{N}$ & Aluminum & & 380.00 & & $\mathrm{ug} / \mathrm{L}$ \\
\hline & & & & Turbidity & & 12.00 & & NTU \\
\hline & & B08NB8 & $\mathbf{Y}$ & Aluminum & & $32.50 \mathrm{U}$ & & $\mathrm{ug} / \mathrm{L}$ \\
\hline & $9 / 29 / 93$ & B096SO & $\mathbf{N}$ & Aluminum & & 840.00 & 328.00 & $\mathrm{ug} / \mathrm{L}$ \\
\hline & & & & Turbidity & & 20.00 & & NTU \\
\hline & & B09654 & $Y$ & Aluminum & & $32.50 \mathrm{U}$ & & $\mathrm{ug} / \mathrm{L}$ \\
\hline & $3 / 18 / 94$ & BOBJYO & $\mathbf{N}$ & Aluminum & & 13000.00 & 2730.00 & $\operatorname{ug} / L$ \\
\hline & & & & Turbidity & & 360.00 & & NTU \\
\hline & & BOBJY4 & $\mathbf{Y}$ & Aluminum & & $32.50 \mathrm{U}$ & & $\mathrm{ug} / \mathrm{L}$ \\
\hline & $10 / 04 / 94$ & BocYW7 & $\mathrm{N}$ & Turbidity & & 100.00 & & NTU \\
\hline & $2 / 15 / 95$ & BODQJ5 & $\mathbf{N}$ & Turbidity & & 3.98 & & NTU \\
\hline & & & & & & 9.50 & & NTU \\
\hline & & BODQJ9 & $Y$ & Aluminum & & $26.00 \mathrm{U}$ & & $\mathrm{ug} / \mathrm{L}$ \\
\hline & $8 / 09 / 95$ & BOG9S3 & $\mathrm{N}$ & Turbidity & & 6.38 & · & NTU \\
\hline & $2 / 13 / 96$ & BOH9Y2 & $\mathbf{N}$ & Turbidity & & 2.72 & & NTU \\
\hline & & BOH9Y6 & $\mathbf{Y}$ & Aluminum & & $31.00 \mathrm{U}$ & & $\mathrm{ug} / \mathrm{L}$ \\
\hline & $8 / 12 / 96$ & B0J6G3 & $\mathrm{N}$ & Turbidity & & 3.10 & & NTU \\
\hline & $11 / 12 / 96$ & BOTML7 & $\mathrm{N}$ & Turbidity & & 4.62 & & NTU \\
\hline & & B0 JML8 & $Y$ & Aluminum & & $58.50 \mathrm{U}$ & & $u g / L$ \\
\hline & $2 / 04 / 97$ & B0K1J7 & $\mathbf{N}$ & Turbidity & . & 4.86 & & NTU \\
\hline & & B0KIJ8 & $\mathbf{Y}$ & Aluminum & & $33.60 \mathrm{U}$ & & $\mathrm{ug} / \mathrm{L}$ \\
\hline & $5 / 13 / 97$ & B0KC86 & $\mathrm{N}$ & Tuxbidity & & 18.30 & & NTU \\
\hline ' & & В0КС 87 & $\mathbf{Y}$ & Aluminum & & 18300.00 & & $\mathrm{ug} / \mathrm{L}$ \\
\hline & $8 / 07 / 97$ & B0ID55 & $\mathbf{N}$ & Turbidity & & 17.10 & & NTU \\
\hline & & B0LD56 & $Y$ & Aluminum & & $31.50 \mathrm{BC}$ & & $\mathrm{ug} / \mathrm{L}$ \\
\hline & $11 / 12 / 97$ & BOM9P5 & $Y$ & Aluminum & & $58.30 \mathrm{U}$ & & $\mathrm{ug} / \mathrm{L}$ \\
\hline & & В0M9P6 & $\mathrm{N}$ & Turbidity & & 10.30 & & NTU \\
\hline & $2 / 11 / 98$ & BOMYP8 & $y$ & Aluminum & & $38.90 \mathrm{~B}$ & & $\mathrm{ug} / \mathrm{L}$ \\
\hline & & BOMYP9 & $\mathrm{N}$ & Turbidity & & 11.00 & & NTU \\
\hline & $6 / 23 / 98$ & BONMB7 & $\mathrm{Y}$ & Aluminum & & $23.60 \mathrm{UC}$ & & $u g / L$ \\
\hline & & BONMB8 & $\mathbf{N}$ & Turbidity & & 4.01 & & NTU \\
\hline
\end{tabular}




\section{Data Table 3. (contd)}

$$
\text { GeODAT Report - 2/09/99 }
$$

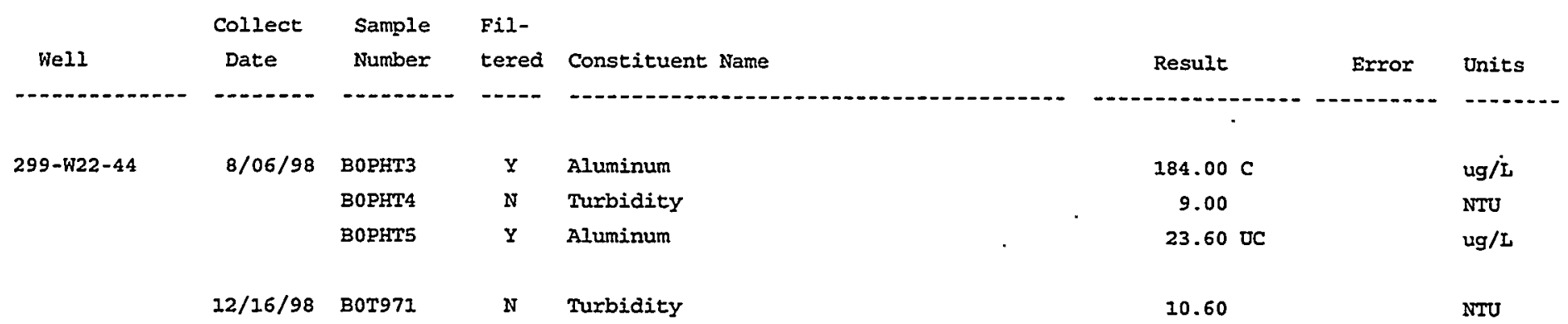




\section{Data Table 3. (contd)}

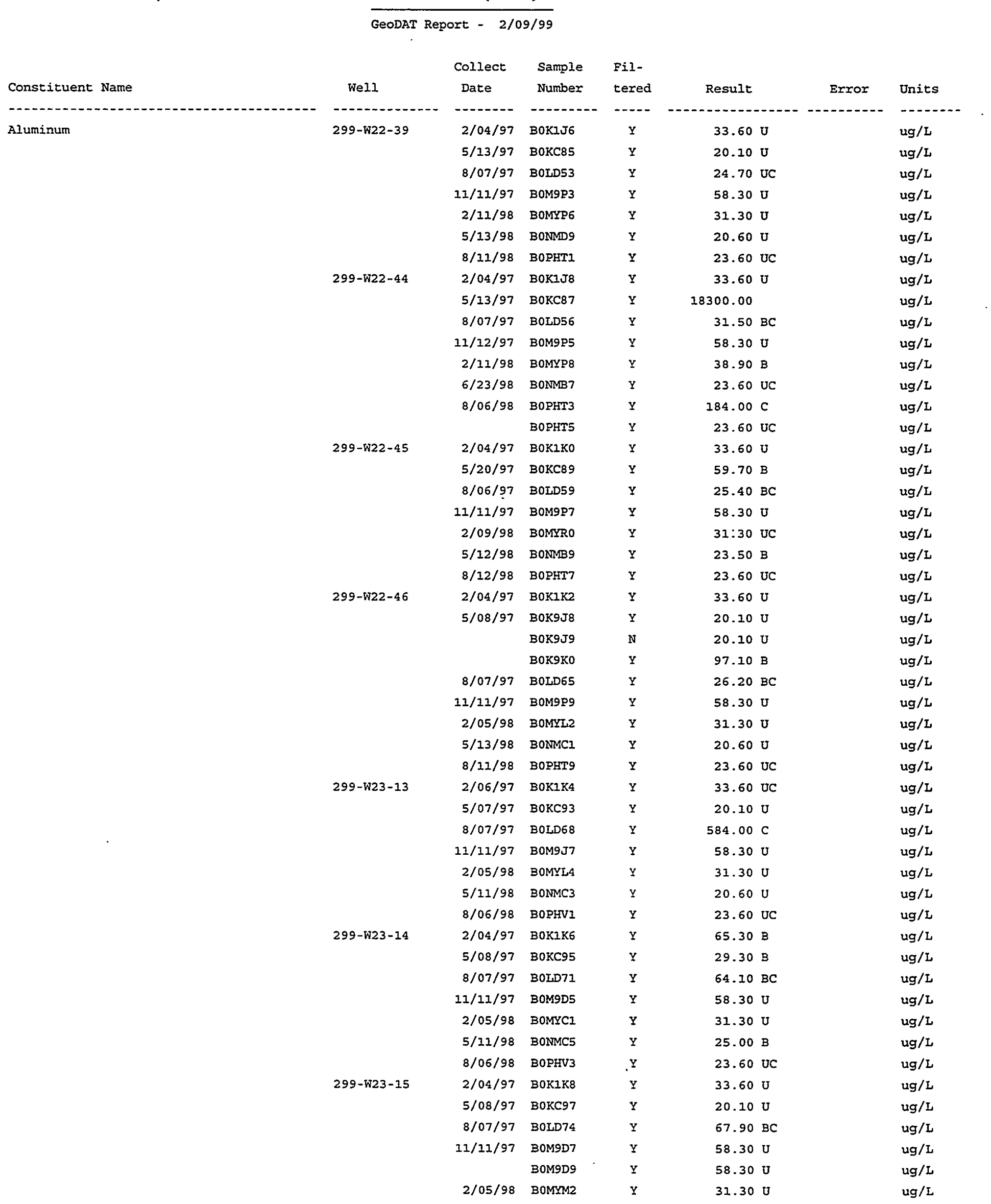

\section{B.88}


Data Table 3. (contd)

GeODAT Report - 2/09/99

\begin{tabular}{|c|c|c|c|c|c|c|c|}
\hline Constituent Name & Well & $\begin{array}{l}\text { Collect } \\
\text { Date }\end{array}$ & $\begin{array}{l}\text { Sample } \\
\text { Number }\end{array}$ & $\begin{array}{l}\text { Fil- } \\
\text { tered }\end{array}$ & Result & Error & Units \\
\hline - & 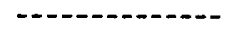 & $-\cdots--$ & $-----\cdot-$ & -.... & - & $-\cdots-\cdots$ & $\cdots$ \\
\hline \multirow[t]{2}{*}{ Aluminum } & 299-พ23-15 & $5 / 11 / 98$ & BONMC7 & $\mathbf{Y}$ & $30.20 \mathrm{~B}$ & & $\mathrm{ug} / \mathrm{L}$ \\
\hline & & $8 / 06 / 98$ & BOPHV5 & $\mathbf{Y}$ & $23.60 \mathrm{UC}$ & & $\mathrm{ug} / \mathrm{L}$ \\
\hline \multirow[t]{48}{*}{ Calcium } & 299-พ22-39 & $2 / 04 / 97$ & BOKIJ6 & $\mathbf{Y}$ & $18500.00 \mathrm{CEQ}$ & & ug/L \\
\hline & & $5 / 13 / 97$ & B0KC85 & $Y$ & 17900.00 & & ug/L \\
\hline & & $8 / 07 / 97$ & B0ID53 & $\mathbf{Y}$ & $18100.00 \mathrm{C}$ & & $\mathrm{ug} / \mathrm{L}$ \\
\hline & & $11 / 11 / 97$ & ВОМ9P3 & $\mathbf{Y}$ & 18400.00 & & $\mathrm{ug} / \mathrm{L}$ \\
\hline & & $2 / 11 / 98$ & BOMYP6 & $Y$ & $17600.00 \mathrm{C}$ & & $\operatorname{ug} / \mathrm{L}$ \\
\hline & & $5 / 13 / 98$ & BOMMD & $\mathbf{y}$ & 18000.00 & & $\mathrm{ug} / \mathrm{L}$ \\
\hline & & $8 / 11 / 98$ & BOPHTI & $\mathbf{y}$ & $17300.00 \mathrm{C}$ & & $\mathrm{ug} / \mathrm{L}$ \\
\hline & 299-W22-44 & $2 / 04 / 97$ & B0K1J8 & $\mathbf{Y}$ & $15800.00 \mathrm{CEQ}$ & & $\mathrm{ug} / \mathrm{L}$ \\
\hline & & $5 / 13 / 97$ & BOKC87 & $\mathbf{Y}$ & 1670.00 & & $\mathrm{ug} / \mathrm{L}$ \\
\hline & & $8 / 07 / 97$ & BoLD56 & $\mathbf{y}$ & $18900.00 \mathrm{C}$ & & $\mathrm{ug} / \mathrm{L}$ \\
\hline & & $11 / 12 / 97$ & B0M9P5 & $\mathbf{Y}$ & 16500.00 & & $\operatorname{ug} / \mathrm{L}$ \\
\hline & & $2 / 11 / 98$ & BOMYP8 & $\mathbf{y}$ & 17700.00 & & $\mathrm{ug} / \mathrm{L}$ \\
\hline & $\cdot$ & $6 / 23 / 98$ & BONMB7 & $\mathbf{Y}$ & $29500.00 \mathrm{C}$ & & $\mathrm{ug} / \mathrm{L}$ \\
\hline & & $8 / 06 / 98$ & BOPHT3 & $\mathbf{Y}$ & $19200.00 \mathrm{C}$ & & ug/L \\
\hline & & & BOPHT5 & $\mathbf{Y}$ & $19500.00 \mathrm{C}$ & & ug/L \\
\hline & $299-W 22-45$ & $2 / 04 / 97$ & BOKבKO & $\mathbf{y}$ & $21700.00 \mathrm{CEQ}$ & & $\mathrm{ug} / \mathrm{L}$ \\
\hline & & $5 / 20 / 97$ & B0КC89 & $\mathbf{Y}$ & $23100.00 \mathrm{C}$ & & $\mathrm{ug} / \mathrm{L}$ \\
\hline & & $8 / 06 / 97$ & BoLD59 & $Y$ & $23300.00 \mathrm{C}$ & & $\mathrm{ug} / \mathrm{L}$ \\
\hline & & $11 / 11 / 97$ & BOM9P7 & $\mathbf{y}$ & 26300.00 & & ug/L \\
\hline & & $2 / 09 / 98$ & BOMYRO & $\mathbf{y}$ & $25400.00 \mathrm{CQ}$ & & ug/L \\
\hline & & $5 / 12 / 98$ & BONMB9 & $\mathbf{y}$ & $26500.00 \mathrm{C}$ & & $\mathrm{ug} / \mathrm{L}$ \\
\hline & & $8 / 12 / 98$ & BOPHT7 & $\mathbf{y}$ & $26300.00 \mathrm{C}$ & & $\mathrm{ug} / \mathrm{L}$ \\
\hline & $299-W 22-46$ & $2 / 04 / 97$ & BOK1K2 & $\mathbf{y}$ & $23700.00 \mathrm{CEQ}$ & & $u g / L$ \\
\hline & & $5 / 08 / 97$ & ВоК9ง8 & $\mathbf{y}$ & $25600.00 Q$ & & ug/L \\
\hline & & & BOK9J9 & N & $24600.00 Q$ & & $\mathrm{ug} / \mathrm{L}$ \\
\hline & & & BOK9KO & $\mathbf{y}$ & $25900.00 Q$ & & ug/L \\
\hline & & $8 / 07 / 97$ & B0LD65 & $\mathbf{y}$ & $24400.00 \mathrm{C}$ & & ug $/ \mathrm{L}$ \\
\hline & & $11 / 11 / 97$ & BOM9P9 & $\mathbf{y}$ & 25600.00 & & ug/L \\
\hline & & $2 / 05 / 98$ & BOMYL2 & $\mathbf{Y}$ & 23100.00 & & $\mathrm{ug} / \mathrm{L}$ \\
\hline & & $5 / 13 / 98$ & BONMC1 & $\mathbf{Y}$ & 23300.00 & & $\mathrm{ug} / \mathrm{L}$ \\
\hline & & $8 / 11 / 98$ & BOPHT9 & $\mathbf{y}$ & $23400.00 \mathrm{C}$ & & ug/L \\
\hline & $299-W 23-13$ & $2 / 06 / 97$ & BOKIK4 & $\mathbf{Y}$ & $17700.00 \mathrm{CQ}$ & & $\operatorname{lgg} / \mathrm{L}$ \\
\hline & & $5 / 07 / 97$ & вокC93 & $\mathbf{Y}$ & 19800.00 & & $\operatorname{ug} / \mathrm{L}$ \\
\hline & & $8 / 07 / 97$ & BOLD68 & $y$ & $19000.00 \mathrm{C}$ & & $\mathrm{ug} / \mathrm{L}$ \\
\hline & & $11 / 11 / 97$ & Вом9J7 & $\mathbf{Y}$ & 19600.00 & & $u g / L$ \\
\hline & & $2 / 05 / 98$ & BOMYL4 & $\mathbf{Y}$ & 17500.00 & & ug/L \\
\hline & & $5 / 11 / 98$ & ВомМс3 & $Y$ & $18400.00 \mathrm{C}$ & & $\mathrm{ug} / \mathrm{L}$ \\
\hline & & $8 / 06 / 98$ & BOPHV1 & $Y$ & $18500.00 \mathrm{C}$ & & ug $/ \mathrm{L}$ \\
\hline & $299-พ 23-14$ & $2 / 04 / 97$ & BOK1K6 & $\mathbf{Y}$ & $24500.00 \mathrm{CEQ}$ & & $\mathrm{ug} / \mathrm{L}$ \\
\hline & & $5 / 08 / 97$ & вокC95 & $\mathbf{Y}$ & 23400.00 & & $\mathrm{ug} / \mathrm{I}$ \\
\hline & & $8 / 07 / 97$ & BOLD71 & $\mathrm{Y}$ & $19900.00 \mathrm{C}$ & & $\mathrm{ug} / \mathrm{L}$ \\
\hline & & $11 / 11 / 97$ & BOM9D5 & $\mathbf{Y}$ & 22800.00 & & $\mathrm{ug} / \mathrm{L}$ \\
\hline & & $2 / 05 / 98$ & BOMYC1 & $\mathbf{Y}$ & 17700.00 & & ug/L \\
\hline & & $5 / 11 / 98$ & BONMC5 & $\mathbf{Y}$ & $19500.00 \mathrm{C}$ & & $u g / L$ \\
\hline & & $8 / 06 / 98$ & BOPHV3 & $\mathbf{Y}$ & $21700.00 \mathrm{C}$ & & $\mathrm{ug} / \mathrm{L}$ \\
\hline & 299-W23-15 & $2 / 04 / 97$ & B0K1K8 & $\mathbf{Y}$ & $21500.00 \mathrm{CEQ}$ & & $\mathrm{ug} / \mathrm{L}$ \\
\hline & & $5 / 08 / 97$ & B0КС 97 & $\mathrm{Y}$ & 22100.00 & & $\mathrm{ug} / \mathrm{I}$ \\
\hline & & $8 / 07 / 97$ & BOID74 & $Y$ & $22500.00 \mathrm{C}$ & & $\mathrm{ug} / \mathrm{I}$ \\
\hline
\end{tabular}




\section{Data Table 3. (contd)}

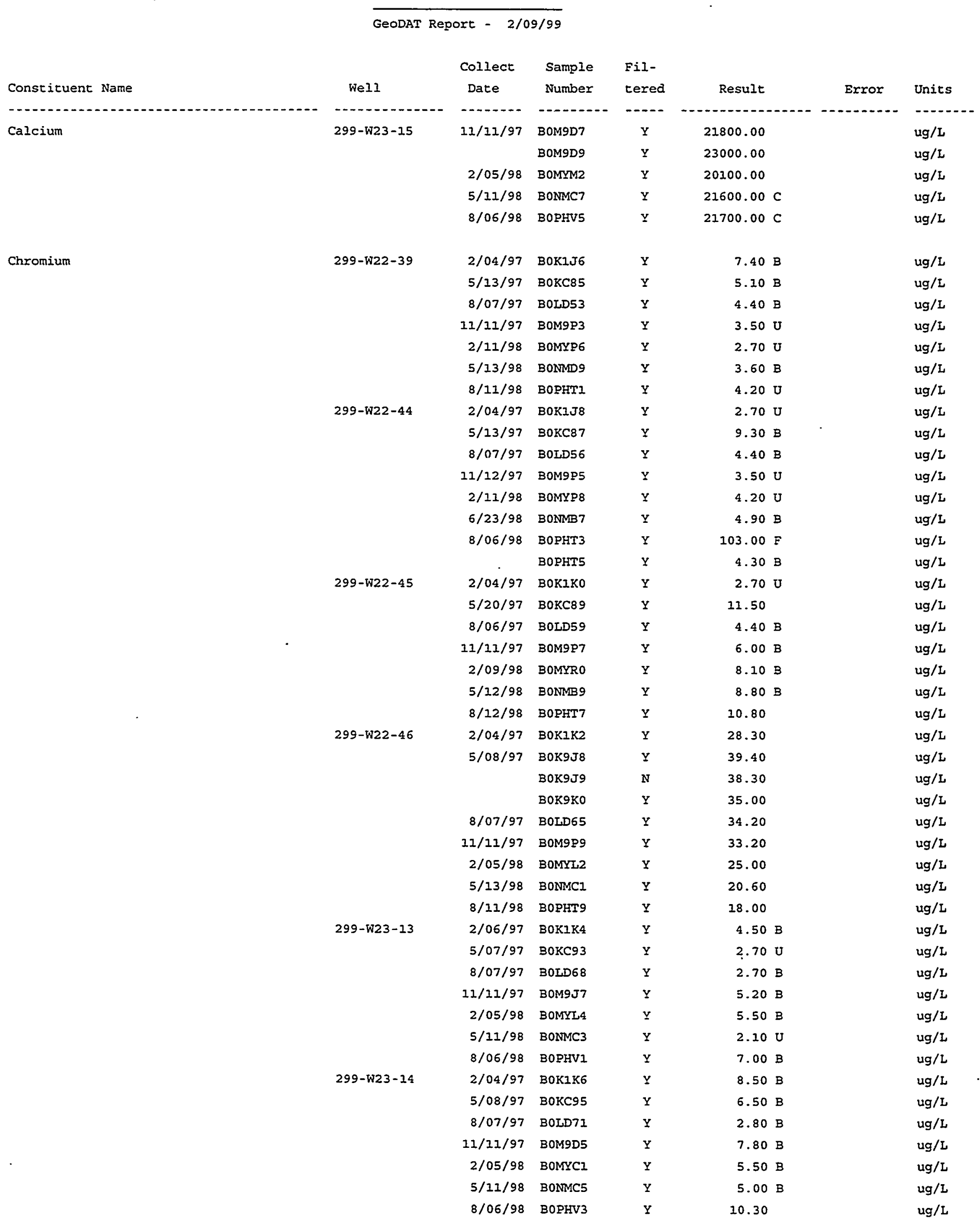


Data Table 3. (contd)

\begin{tabular}{|c|c|c|c|c|c|c|c|}
\hline \multirow{3}{*}{ Constituent Name } & & & & \multirow{3}{*}{$\begin{array}{l}\text { Fil- } \\
\text { tered }\end{array}$} & \multirow{3}{*}{ Result } & & \multirow{3}{*}{ Units } \\
\hline & \multicolumn{3}{|c|}{ GeODAT Report - 2/09/99 } & & & & \\
\hline & Well & $\begin{array}{l}\text { Collect } \\
\text { Date }\end{array}$ & $\begin{array}{l}\text { Sample } \\
\text { Number }\end{array}$ & & & Error & \\
\hline י & $\cdots+-\cdots$ & $-\cdots \cdots$ & $\cdots---$ & $\cdots$ & ---------1 & $----n---$ & $\cdots$ \\
\hline \multirow[t]{8}{*}{ Chromium } & $299-W 23-15$ & $2 / 04 / 97$ & B0K1K8 & $\mathbf{Y}$ & $5.60 \mathrm{~B}$ & & ug/L \\
\hline & & $5 / 08 / 97$ & B0KC97 & $\mathbf{Y}$ & $2.70 \mathrm{U}$ & & $\mathrm{ug} / \mathrm{L}$ \\
\hline & & $8 / 07 / 97$ & B0LD74 & $\mathbf{Y}$ & $4.30 \mathrm{~B}$ & & $\mathrm{ug} / \mathrm{L}$ \\
\hline & & $11 / 11 / 97$ & BOM9D7 & $\mathbf{Y}$ & $3.50 \mathrm{U}$ & & $\mathrm{ug} / \mathrm{L}$ \\
\hline & & & BOM9D9 & $\mathbf{Y}$ & $4.00 \mathrm{~B}$ & & $\mathrm{ug} / \mathrm{L}$ \\
\hline & & $2 / 05 / 98$ & B0MYN2 & $\mathbf{Y}$ & $2.70 \mathrm{U}$ & & $\mathrm{ug} / \mathrm{L}$ \\
\hline & & $5 / 11 / 98$ & BONMC7 & $\mathbf{Y}$ & $2.10 \mathrm{U}$ & & $\mathrm{ug} / \mathrm{L}$ \\
\hline & & $8 / 06 / 98$ & BOPHV5 & $Y$ & $7.20 \mathrm{~B}$ & & ug/L \\
\hline \multirow[t]{42}{*}{ Iron } & 299-พ22-39 & $2 / 04 / 97$ & B0K1J6 & $Y$ & $69.40 \mathrm{CQ}$ & & $\mathrm{ug} / \mathrm{L}$ \\
\hline & & $5 / 13 / 97$ & B0KC85 & $\mathbf{Y}$ & $41.80 \mathrm{C}$ & & $\mathrm{ug} / \mathrm{L}$ \\
\hline & & $8 / 07 / 97$ & B0LD53 & $Y$ & $26.80 \mathrm{BC}$ & & $\mathrm{ug} / \mathrm{L}$ \\
\hline & & $12 / 11 / 97$ & Вом9P3 & $\mathbf{Y}$ & 44.20 & & $u g / L$ \\
\hline & & $2 / 11 / 98$ & BOMYP6 & $Y$ & $82.50 \mathrm{C}$ & & $\mathrm{ug} / \mathrm{L}$ \\
\hline & & $5 / 13 / 98$ & BONMD9 & $\mathbf{Y}$ & 51.90 & & $\mathrm{ug} / \mathrm{L}$ \\
\hline & & $8 / 11 / 98$ & BOPHT1 & $\mathbf{Y}$ & $29.70 \mathrm{BC}$ & & $\mathrm{ug} / \mathrm{L}$ \\
\hline & $299-พ 22-44$ & $2 / 04 / 97$ & BOK1J8 & $Y$ & $52.10 \mathrm{CQ}$ & & $\mathrm{ug} / \mathrm{L}$ \\
\hline & & $5 / 13 / 97$ & B0KC87 & $\mathbf{Y}$ & $1120.00 \mathrm{C}$ & & $u g / L$ \\
\hline & & $8 / 07 / 97$ & B0LD56 & $\mathbf{Y}$ & $27.30 \mathrm{BC}$ & & $\mathrm{ug} / \mathrm{L}$ \\
\hline & & $11 / 12 / 97$ & B0M9P5 & $Y$ & $54.00 \mathrm{C}$ & & $\mathrm{ug} / \mathrm{L}$ \\
\hline & & $2 / 1 I / 98$ & BOMYP8 & $\mathbf{Y}$ & $57.60 \mathrm{CG}$ & & $\mathrm{ug} / \mathrm{L}$ \\
\hline & & $6 / 23 / 98$ & BONMB7 & $Y$ & $27.70 \mathrm{BC}$ & & $\mathrm{ug} / \mathrm{L}$ \\
\hline & & $8 / 06 / 98$ & BOPHT3 & $Y$ & $766.00 \mathrm{C}$ & & $\mathrm{ug} / \mathrm{I}$ \\
\hline & & & BOPHT5 & $\mathrm{y}$ & $64.50 \mathrm{C}$ & & $\mathrm{ug} / \mathrm{L}$ \\
\hline & 299-พ22-45 & $2 / 04 / 97$ & BOKIKO & $\mathbf{Y}$ & $42.30 \mathrm{CQ}$ & & $u g / t$ \\
\hline & & $5 / 20 / 97$ & B0КC89 & $Y$ & $76.80 \mathrm{C}$ & & $u g / L$ \\
\hline & . & $8 / 06 / 97$ & B0LD59 & $Y$ & $17.40 \mathrm{BC}$ & & $u g / L$ \\
\hline & & $11 / 11 / 97$ & BOMSP7 & $\mathrm{Y}$ & $29.00 \mathrm{~B}$ & & ug $/ \mathrm{L}$ \\
\hline & & $2 / 09 / 98$ & BOMYRO & $Y$ & $27.30 \mathrm{BC}$ & & $u g / L$ \\
\hline & & $5 / 12 / 98$ & BONMB9 & $\mathbf{Y}$ & 34.30 & & $u g / L$ \\
\hline & & $8 / 12 / 98$ & BOPHT7 & $Y$ & $21.90 \mathrm{BC}$ & & $u g / I$ \\
\hline & 299-พ22-46 & $2 / 04 / 97$ & BOK1K2 & $\mathbf{Y}$ & $67.90 \mathrm{CQ}$ & & $u g / L$ \\
\hline & & $5 / 08 / 97$ & ВоК9ง8 & $\mathbf{Y}$ & $29.60 \mathrm{~B}$ & & $\mathrm{ug} / \mathrm{L}$ \\
\hline & & & B0К9J9 & $\mathrm{N}$ & 96.10 & & $u g / L$ \\
\hline & & & ВоК9K0 & $y$ & $25.80 \mathrm{~B}$ & & $\mathrm{ug} / \mathrm{L}$ \\
\hline & & $8 / 07 / 97$ & B0LD65 & $\mathbf{Y}$ & $82.80 \mathrm{C}$ & & $\mathrm{ug} / \mathrm{L}$ \\
\hline & & $11 / 11 / 97$ & ВоM9P9 & $y$ & 86.70 & & $\mathrm{ug} / \mathrm{L}$ \\
\hline & & $2 / 05 / 98$ & BOMYL2 & $\mathbf{Y}$ & $31.80 \mathrm{C}$ & & $\mathrm{ug} / \mathrm{L}$ \\
\hline & & $5 / 13 / 98$ & BONMCl & $\mathbf{Y}$ & 56.80 & & $\mathrm{ug} / \mathrm{L}$ \\
\hline & & $8 / 11 / 98$ & BOPHT9 & $Y$ & $26.80 \mathrm{BC}$ & & $u g / L$ \\
\hline & $299-$ W23-13 & $2 / 06 / 97$ & B0K1K4 & $\mathbf{Y}$ & $42.70 \mathrm{C}$ & & $\mathrm{ug} / \mathrm{L}$ \\
\hline & & $5 / 07 / 97$ & $30 \mathrm{KC} 93$ & $\mathbf{Y}$ & $17.40 \mathrm{BC}$ & & $u g / L$ \\
\hline & & $8 / 07 / 97$ & B0LD68 & $\mathbf{Y}$ & $536.00 \mathrm{C}$ & & $u g / L$ \\
\hline & & $11 / 11 / 97$ & BOM9J7 & $\mathbf{Y}$ & 35.70 & & $\mathrm{ug} / \mathrm{L}$ \\
\hline & & $2 / 05 / 98$ & BOMYL4 & $Y$ & $39.50 \mathrm{C}$ & & $\mathrm{ug} / \mathrm{L}$ \\
\hline & & $5 / 11 / 98$ & BONMC3 & $Y$ & 40.80 & & $u g / i$ \\
\hline & & $8 / 06 / 98$ & BOPHVI & $Y$ & $42.50 \mathrm{C}$ & & $\mathrm{ug} / \mathrm{L}$ \\
\hline & $299-W 23-14$ & $2 / 04 / 97$ & BOKZK6 & $\mathbf{Y}$ & $59.30 \mathrm{CQ}$ & & ug/L \\
\hline & & $5 / 08 / 97$ & В0Кс95 & $Y$ & $35.40 \mathrm{C}$ & & $\mathrm{ug} / \mathrm{L}$ \\
\hline & & $8 / 07 / 97$ & BOLD71 & $\Psi$ & $77.10 \mathrm{C}$ & & $u g / L$ \\
\hline & & $11 / 11 / 97$ & BOM9D5 & $\mathbf{Y}$ & 45.80 & & $\mathrm{ug} / \mathrm{L}$ \\
\hline
\end{tabular}




\section{Data Table 3. (contd)}

\begin{tabular}{|c|c|c|c|c|c|c|c|}
\hline \multirow[b]{3}{*}{ Constituent Name } & & & & \multirow[b]{3}{*}{$\begin{array}{l}\text { Fil- } \\
\text { tered }\end{array}$} & \multirow{3}{*}{\multicolumn{2}{|c|}{ Result }} & \multirow[b]{3}{*}{ Units } \\
\hline & \multicolumn{3}{|c|}{ GeODAT Report - 2/09/99 } & & & & \\
\hline & Well & $\begin{array}{l}\text { Collect } \\
\text { Date }\end{array}$ & $\begin{array}{l}\text { Sample } \\
\text { Number }\end{array}$ & & & & \\
\hline $\begin{array}{l}-1 \\
-1\end{array}$ & $-\cdots-1-n-n$ & $\cdots+\cdots$ & 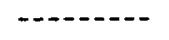 & ---- & $---1--1--$ & 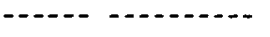 & $\cdots$ \\
\hline \multirow[t]{11}{*}{ Iron } & $299-w 23-14$ & $2 / 05 / 98$ & BOMYC1 & $\mathbf{Y}$ & 49.10 & c & $u g / L$ \\
\hline & & $5 / 21 / 98$ & BONMC5 & $\mathbf{Y}$ & 33.40 & & ug/L \\
\hline & & $8 / 06 / 98$ & BOPHV3 & $\mathbf{Y}$ & 58.20 & c & $u g / L$ \\
\hline & $299-$ W23-15 & $2 / 04 / 97$ & B0K1K8 & $\mathbf{Y}$ & 78.50 & $C Q$ & $\mathrm{ug} / \mathrm{L}$ \\
\hline & & $5 / 08 / 97$ & B0KC97 & $Y$ & 24.80 & $\mathrm{BC}$ & ug/L \\
\hline & & $8 / 07 / 97$ & BOLD74 & $Y$ & 46.30 & $c$ & ug/L \\
\hline & & $11 / 11 / 97$ & BOM9D7 & $\mathbf{Y}$ & 31.70 & & $\mathrm{ug} / \mathrm{L}$ \\
\hline & & & BOM9D9 & $\mathrm{Y}$ & 42.90 & & $\mathrm{ug} / \mathrm{L}$ \\
\hline & & $2 / 05 / 98$ & ВОМYM2 & $\mathbf{Y}$ & 37.90 & $c$ & ug/I \\
\hline & & $5 / 11 / 98$ & BONMC7 & $\mathbf{Y}$ & 37.30 & & $\mathrm{ug} / \mathrm{L}$ \\
\hline & & $8 / 06 / 98$ & BOPHV5 & $\mathrm{Y}$ & 57.90 & c & ug $/ \mathrm{L}$ \\
\hline \multirow[t]{39}{*}{ Magnesium } & $299-W 22-39$ & $2 / 04 / 97$ & B0K1J6 & $\mathbf{Y}$ & 5950.00 & $E Q$ & $\mathrm{ug} / \mathrm{L}$ \\
\hline & & $5 / 13 / 97$ & B0KC85 & $\mathbf{Y}$ & 5690.00 & & $u g / L$ \\
\hline & & $8 / 07 / 97$ & B0ID53 & $Y$ & 5670.00 & c & $\mathrm{ug} / \mathrm{L}$ \\
\hline & & $11 / 11 / 97$ & Вом9P3 & $\mathbf{Y}$ & 5900.00 & & ug/L \\
\hline & & $2 / 11 / 98$ & BOMYP6 & $\mathrm{Y}$ & 5630.00 & & $\mathrm{ug} / \mathrm{L}$ \\
\hline & & $5 / 23 / 98$ & BONMD9 & $y$ & 5640.00 & & $\mathrm{ug} / \mathrm{L}$ \\
\hline & & $8 / 11 / 98$ & BOPHTI & $Y$ & 5610.00 & $\mathrm{CQ}$ & $\mathrm{ug} / \mathrm{L}$ \\
\hline & $299-W 22-44$ & $2 / 04 / 97$ & B0KIJ8 & $\mathrm{Y}$ & 4960.00 & $E Q$ & ug/L \\
\hline & & $5 / 13 / 97$ & B0KC87 & $Y$ & 281.00 & & $\mathrm{ug} / \mathrm{L}$ \\
\hline & & $8 / 07 / 97$ & B0ID56 & $Y$ & 5830.00 & $\mathrm{C}$ & ug/L \\
\hline & & $11 / 12 / 97$ & B0M9P5 & $\mathrm{Y}$ & 5130.00 & & $\operatorname{Lg} / \mathrm{L}$ \\
\hline & & $2 / 11 / 98$ & BOMYP8 & $Y$ & 5570.00 & 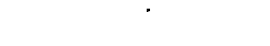 & $\mathrm{ug} / \mathrm{L}$ \\
\hline & & $6 / 23 / 98$ & BONMB7 & $\mathrm{Y}$ & 6020.00 & $C$ & ug/L \\
\hline & & $8 / 06 / 98$ & BOPHT3 & $\mathbf{Y}$ & 6100.00 & $\mathrm{CE}$ & $\mathrm{ug} / \mathrm{L}$ \\
\hline & & & BOPHT5 & $Y$ & 6190.00 & $C E$ & $\mathrm{ug} / \mathrm{L}$ \\
\hline & $299-W 22-45$ & $2 / 04 / 97$ & BOKIKO & $Y$ & 6800.00 & $E Q$ & $\mathrm{ug} / \mathrm{L}$ \\
\hline & & $5 / 20 / 97$ & В0КС89 & $\mathrm{Y}$ & 7090.00 & . & $\mathrm{ug} / \mathrm{L}$ \\
\hline & & $8 / 06 / 97$ & BOLD59 & $\mathrm{Y}$ & 7120.00 & & $\mathrm{ug} / \mathrm{L}$ \\
\hline & & $11 / 11 / 97$ & BOM9P7 & $Y$ & 8150.00 & & $\mathrm{ug} / \mathrm{L}$ \\
\hline & & $2 / 09 / 98$ & BOMYRO & $Y$ & 7760.00 & $c$ & $u g / L$ \\
\hline & & $5 / 12 / 98$ & BONMB9 & $Y$ & 8160.00 & $\mathrm{CQ}$ & $\mathrm{ug} / \mathrm{L}$ \\
\hline & & $8 / 12 / 98$ & BOPHT7 & $\Psi$ & 8170.00 & $\mathrm{CQ}$ & $u g / L$ \\
\hline & $299-W 22-46$ & $2 / 04 / 97$ & $\mathrm{~B} 0 \mathrm{~K} 1 \mathrm{~K} 2$ & $\mathbf{Y}$ & $7960.00 \mathrm{E}$ & $E Q$ & $\mathrm{ug} / \mathrm{L}$ \\
\hline & & $5 / 08 / 97$ & B0K9J8 & $\mathbf{Y}$ & 8380.00 & & $\mathrm{ug} / \mathrm{L}$ \\
\hline & & & В0К959 & $N$ & 8020.00 & & ug/L \\
\hline & & & BoK9KO & $Y$ & 8520.00 & & $u g / L$ \\
\hline & & $8 / 07 / 97$ & B0LD65 & $\mathbf{Y}$ & 8030.00 & c & $\mathrm{ug} / \mathrm{L}$ \\
\hline & & $11 / 11 / 97$ & B0M9P9 & $Y$ & 8560.00 & & $u g / L$ \\
\hline & & $2 / 05 / 98$ & BOMYL2 & $Y$ & 7760.00 & & ug $/ L$ \\
\hline & & $5 / 23 / 98$ & BONMC1 & $\mathbf{Y}$ & 7690.00 & & ug $/ \mathrm{L}$ \\
\hline & & $8 / 11 / 98$ & B0PHT9 & $Y$ & 7860.00 & $\mathrm{CQ}$ & $\mathrm{ug} / \mathrm{L}$ \\
\hline & $299-W 23-13$ & $2 / 06 / 97$ & B0KIK4 & $\mathrm{Y}$ & 5660.00 & & ug/L \\
\hline & & $5 / 07 / 97$ & B0KC93 & $y$ & 6060.00 & & $\mathrm{ug} / \mathrm{L}$ \\
\hline & & $8 / 07 / 97$ & BOLD68 & $\mathrm{Y}$ & 6840.00 & $C$ & $\operatorname{ug} / \mathrm{L}$ \\
\hline & & $11 / 11 / 97$ & BOM9J7 & $Y$ & 6150.00 & & ug/L \\
\hline & & $2 / 05 / 98$ & BOMYL4 & $Y$ & 5510.00 & & $\mathrm{ug} / \mathrm{L}$ \\
\hline & & $5 / 11 / 98$ & BONMC3 & $\mathbf{Y}$ & 5760.00 & $\mathrm{CQ}$ & $\mathrm{ug} / \mathrm{L}$ \\
\hline & & $8 / 06 / 98$ & BOPEVI & $\mathrm{Y}$ & 5860.00 & $\mathrm{CE}$ & ug/L \\
\hline & $299-W 23-14$ & $2 / 04 / 97$ & BOKIK6 & $\Psi$ & 7890.00 & $E Q$ & $\mathrm{ug} / \mathrm{L}$ \\
\hline
\end{tabular}


Data Table 3. (contd)

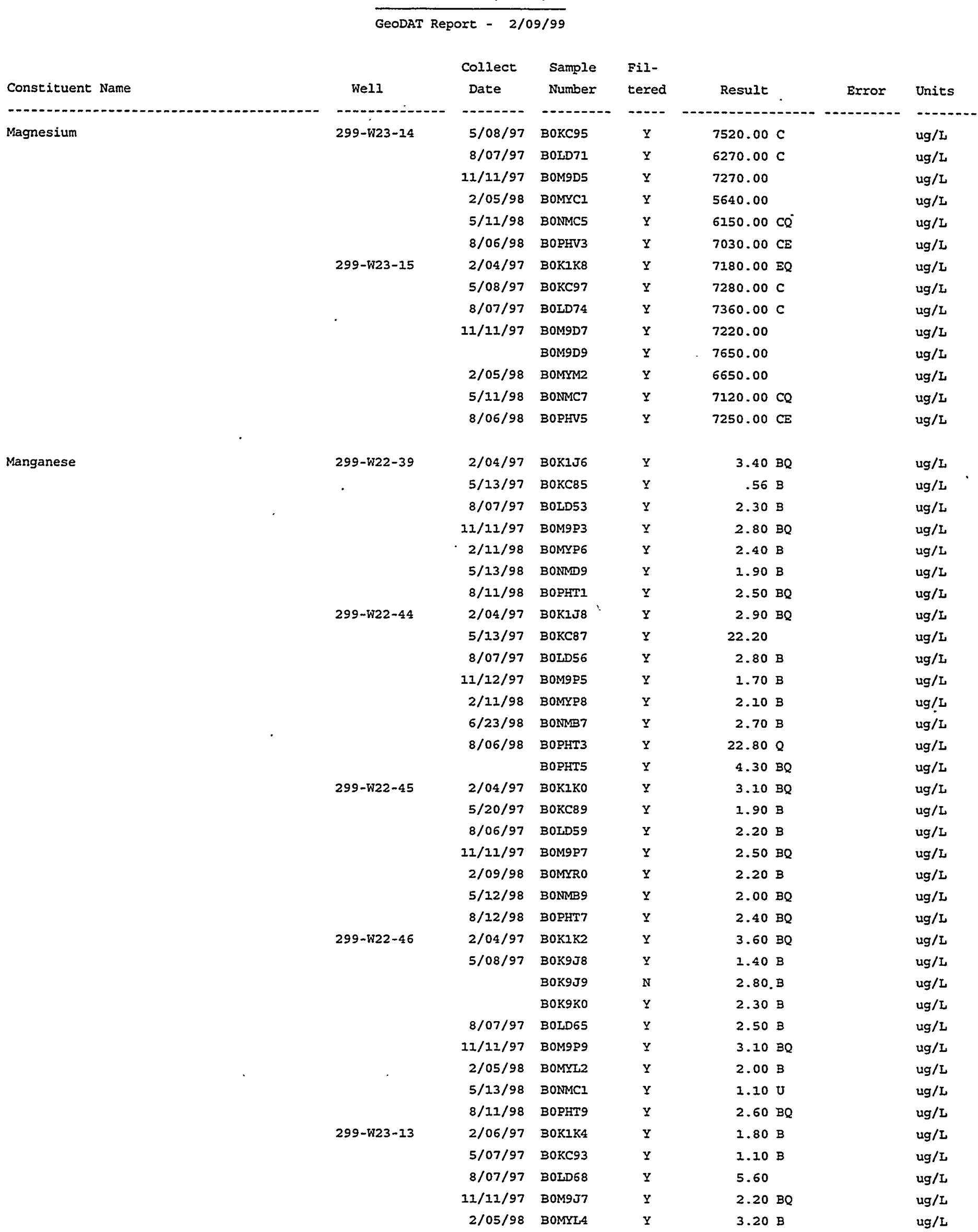


Data Table 3. (contd)

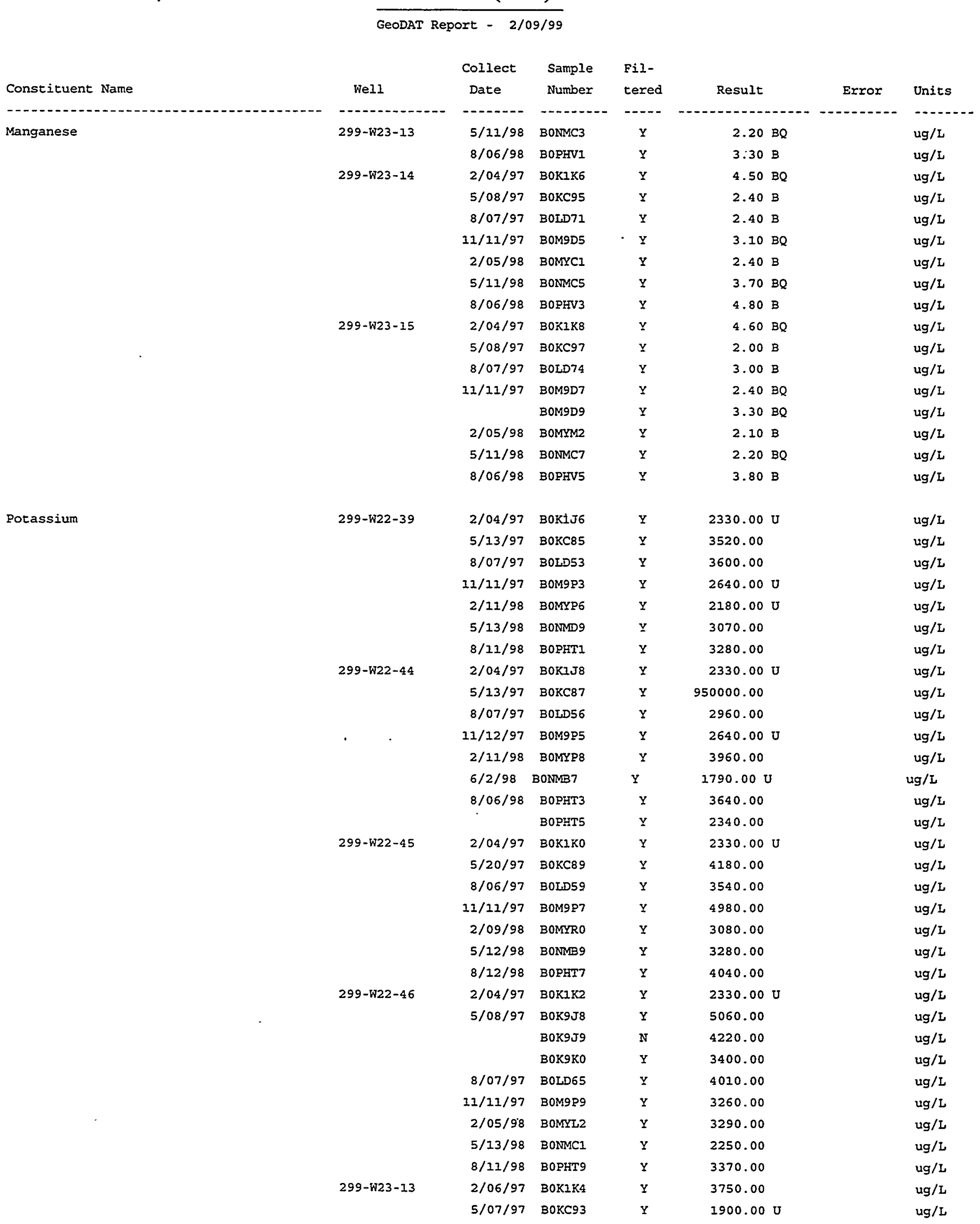




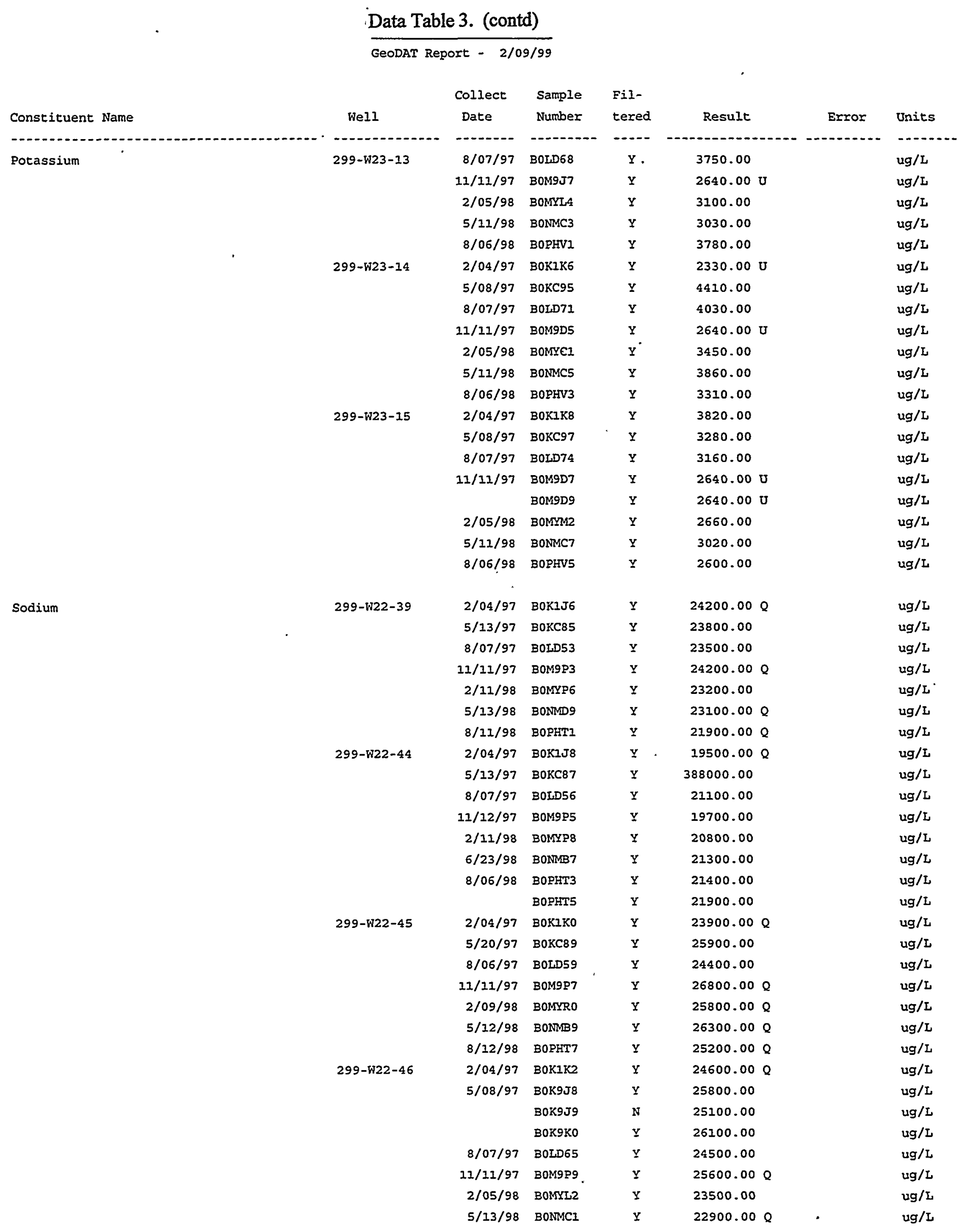

\section{B.95}


Data Table 3. (contd)

GeODAT Report - 2/09/99

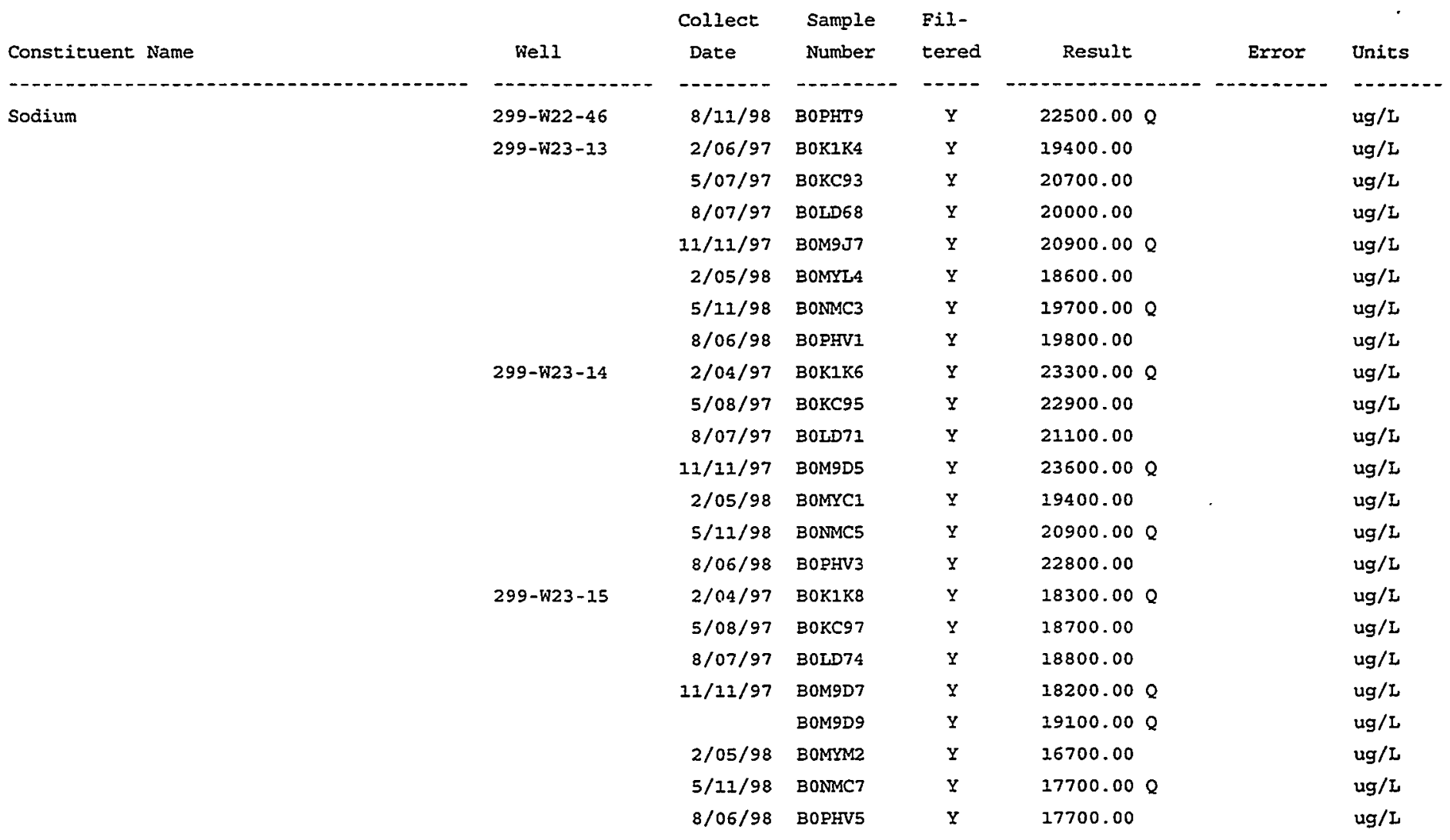


Data Table 3. (contd)

GeODAT Report - 2/09/99

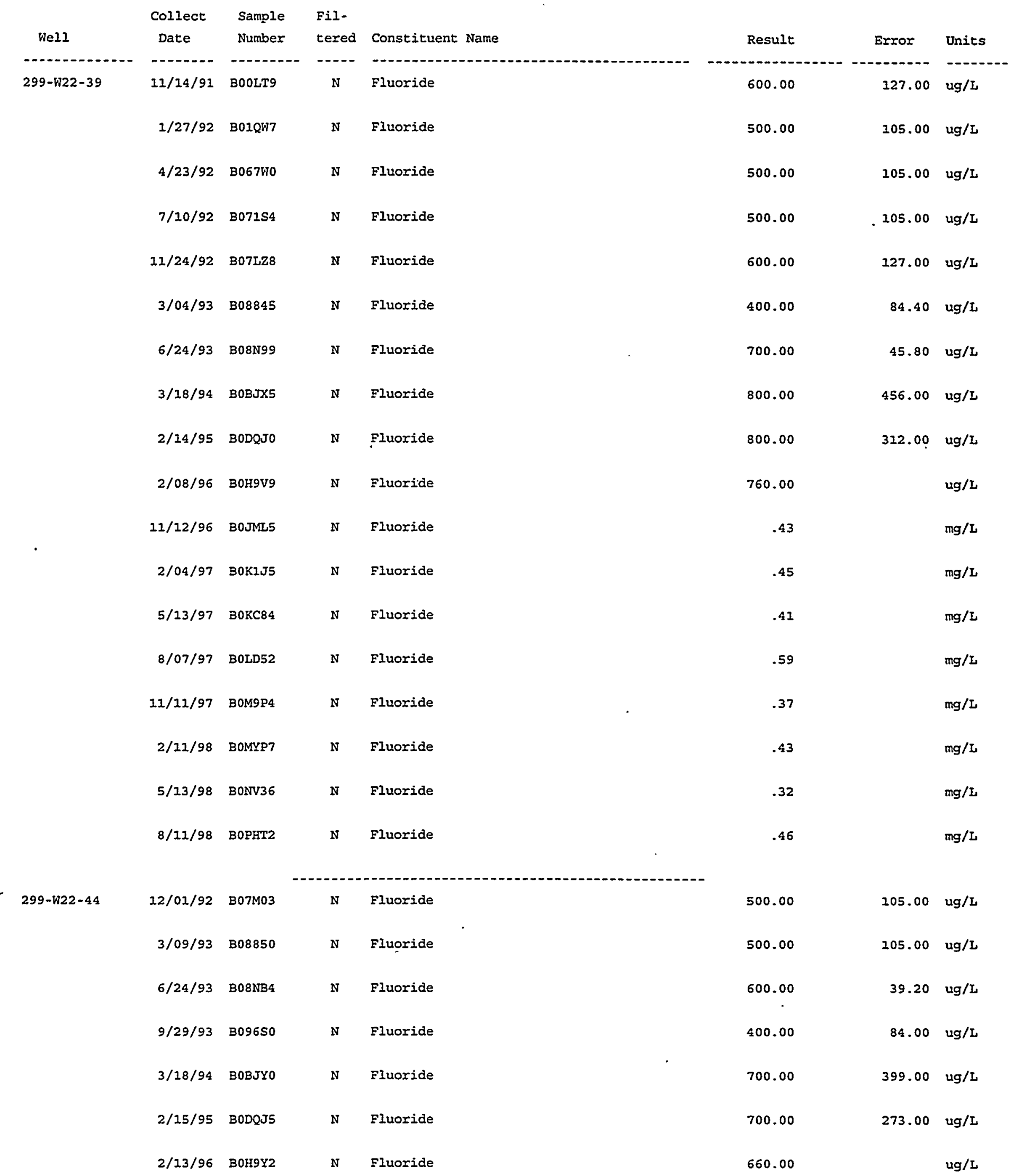




\section{Data Table 3. (contd)}

GeoDAT Report - 2/09/99

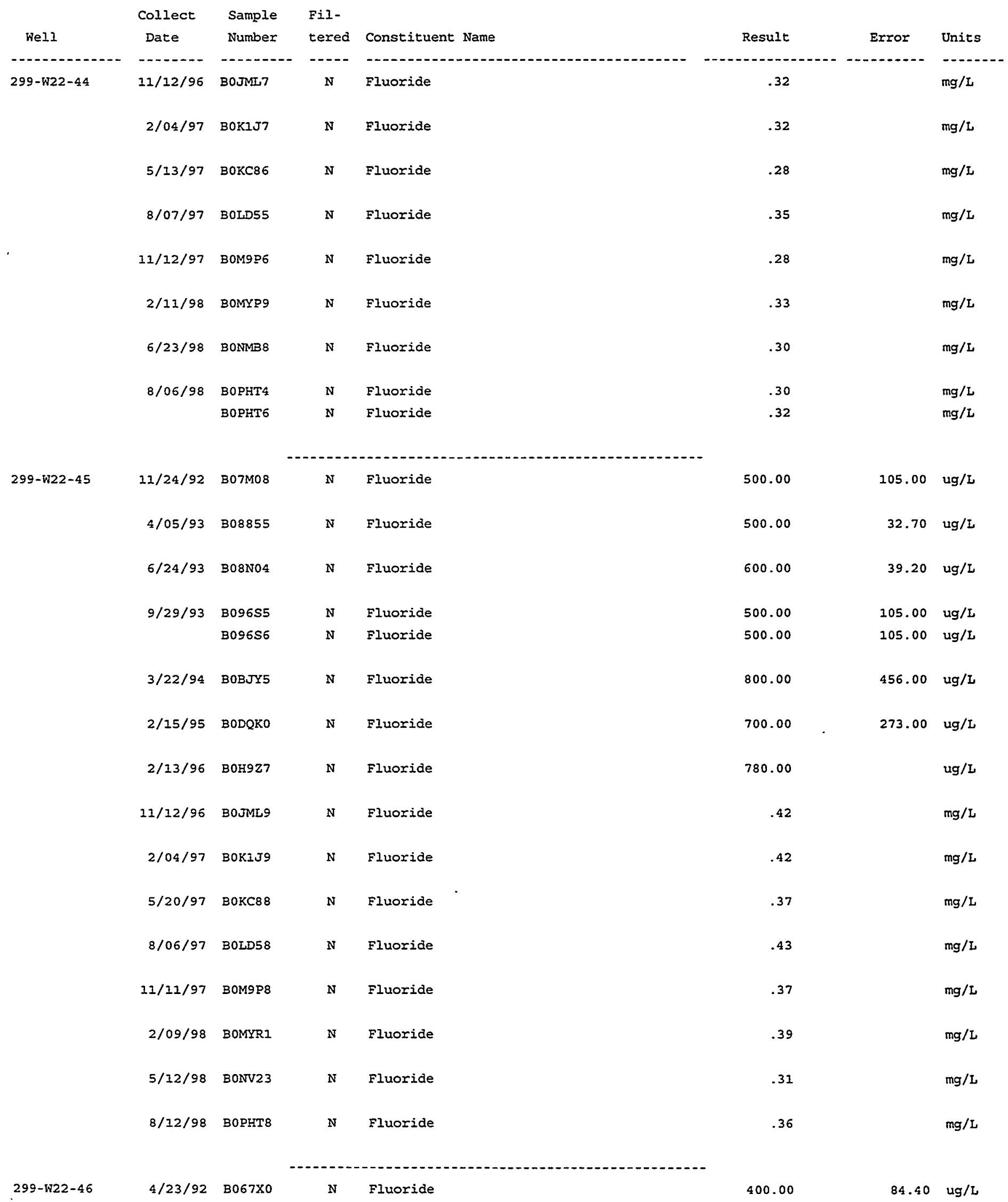


Data Table 3. (contd)

GeoDAT Report - 2/09/99

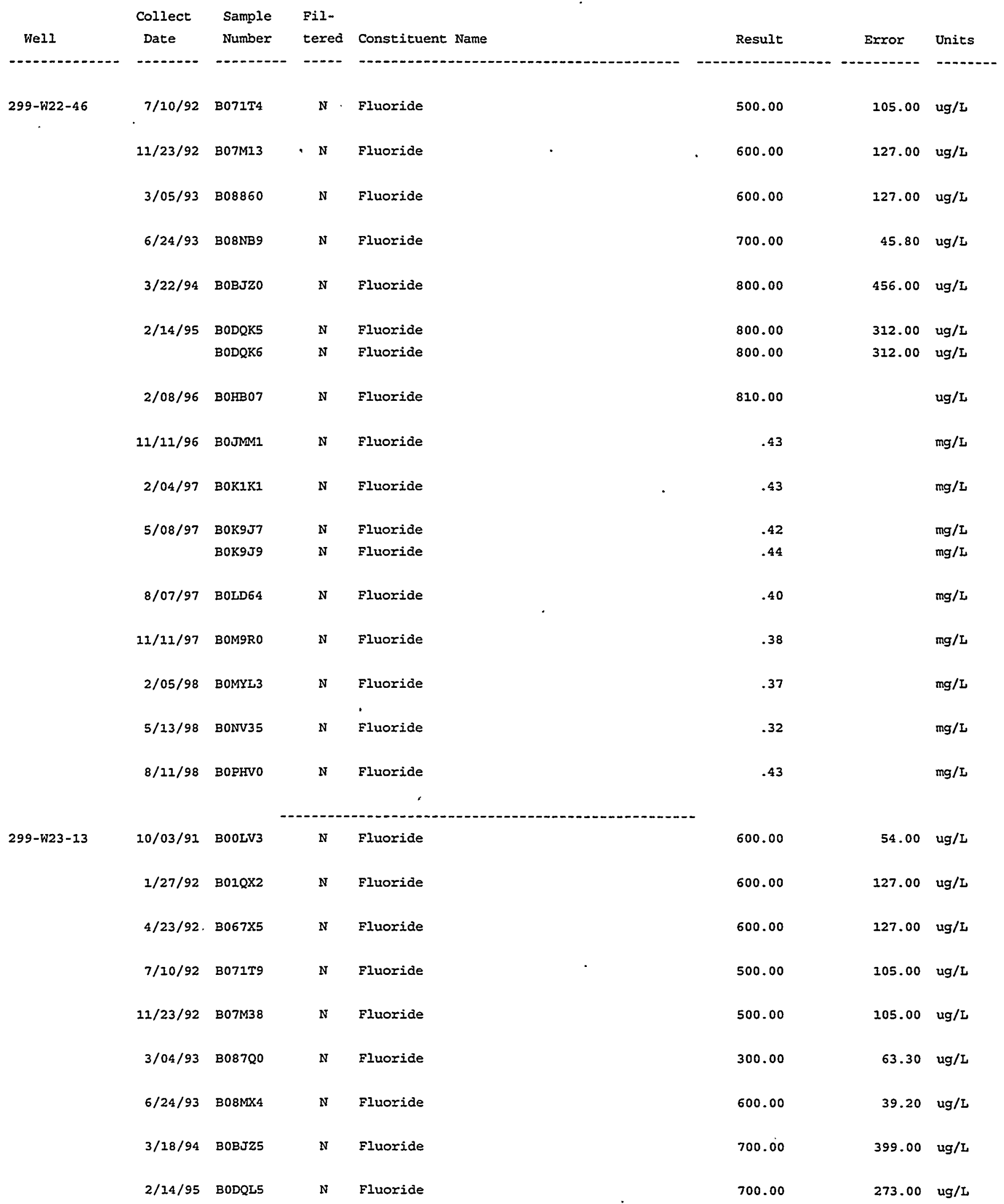


Data Table 3. (contd)

GeODAT Report - 2/09/99

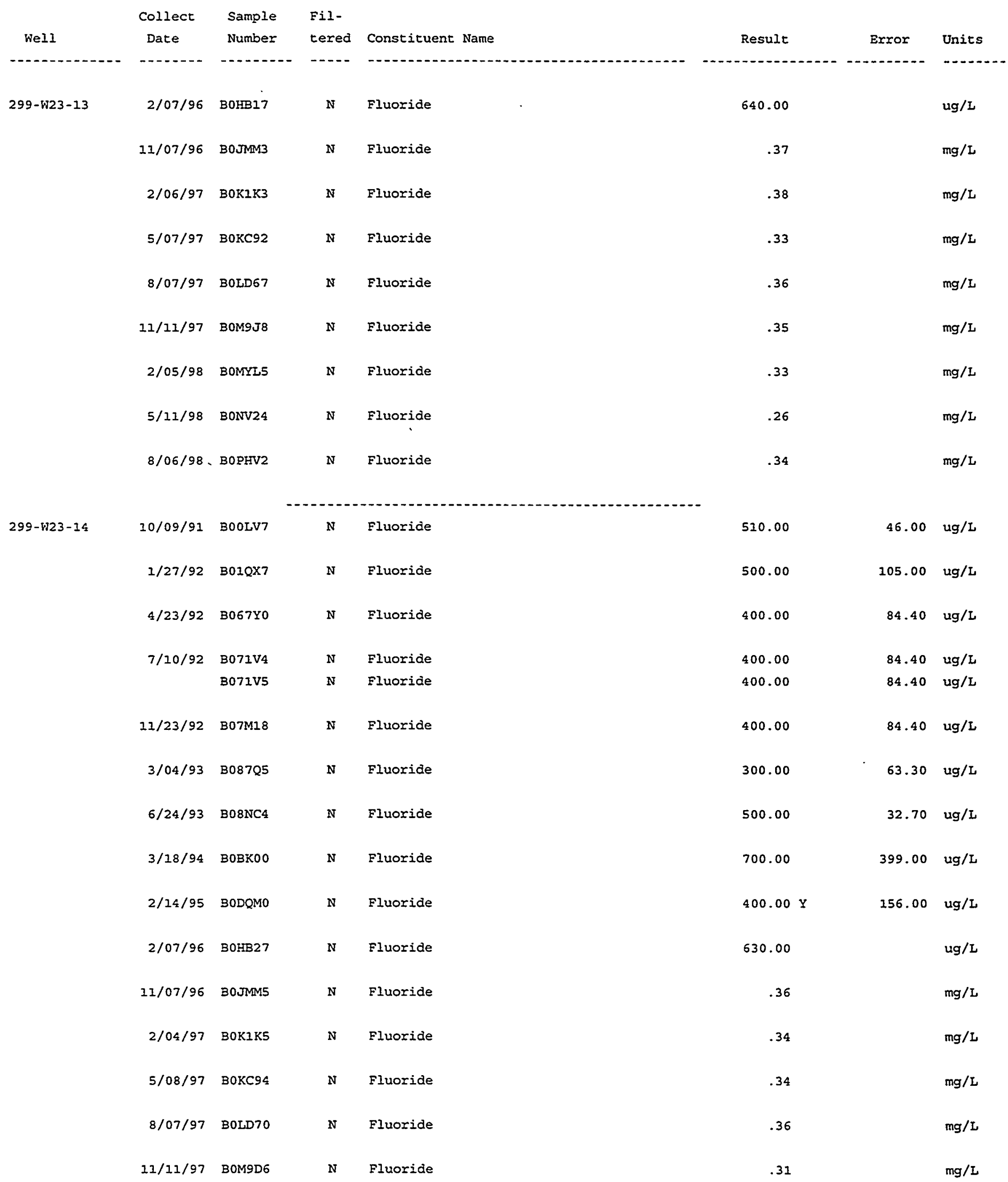


Data Table 3. (contd)

GeoDAT Report - 2/09/99

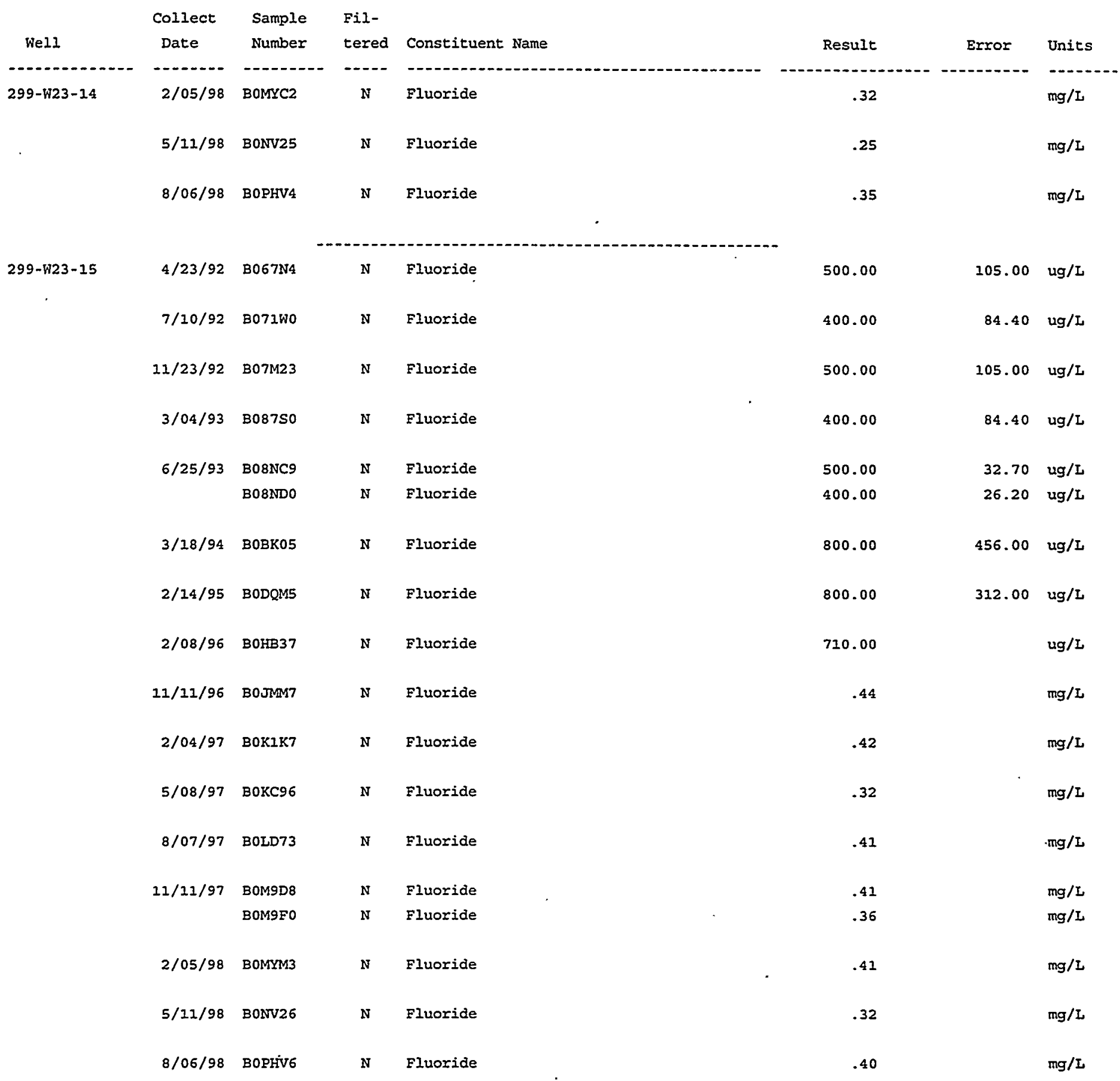


Data Table 4. This table provides data in reference to comment 113.

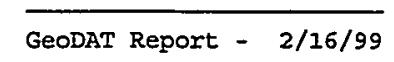

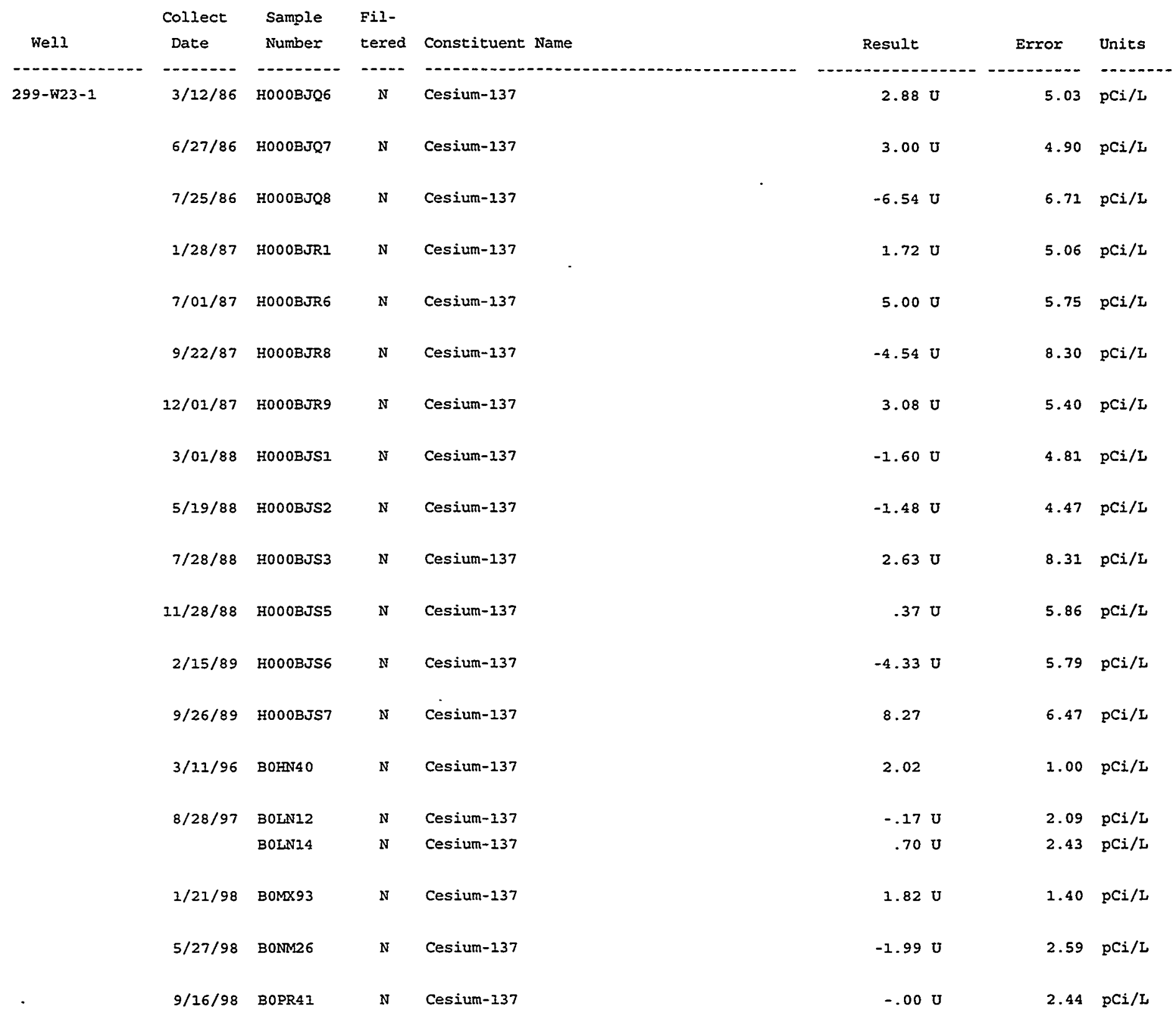




\section{Data Table 5. This table provides data in reference to comment 112.}

\begin{tabular}{|c|c|c|c|c|c|c|c|}
\hline Well & $\begin{array}{l}\text { Collect } \\
\text { Date }\end{array}$ & $\begin{array}{l}\text { Sample } \\
\text { Number }\end{array}$ & $\begin{array}{l}\text { Fil- } \\
\text { tered }\end{array}$ & Constituent Name & Result & Exror & Units \\
\hline n & 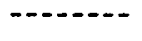 & $-\cdots-. .$. & $\cdots-$ & - - - & ---------- & 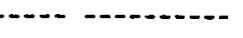 & 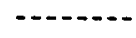 \\
\hline \multirow[t]{7}{*}{ 299-W23-1 } & $12 / 03 / 91$ & BOOMF1 & $N$ & Conductivity & 228.00 & & umhos/cm \\
\hline & $3 / 11 / 96$ & BOHN4O & $\mathbf{N}$ & Conductivity & 231.00 & ' & umhos/cm \\
\hline & $8 / 28 / 97$ & BOLN11 & $\mathbf{N}$ & Conductivity & 410.00 & & umhos $/ \mathrm{cm}$ \\
\hline & $1 / 21 / 98$ & BOMX90 & $\mathbf{N}$ & Conductivity & 333.00 & & umhos $/ \mathrm{cm}$ \\
\hline & & BOMXN5 & $\mathbf{N}$ & Conductivity & 365.00 & & umhos $/ \mathrm{cm}$ \\
\hline & $5 / 27 / 98$ & BONM26 & $\mathbf{N}$ & Conductivity & $249.00 \mathrm{Y}$ & I & umhos/cm \\
\hline & $9 / 16 / 98$ & BOPR4I & $\mathrm{N}$ & Conductivity & 249.00 & & umhos/cm \\
\hline \multirow[t]{15}{*}{ 299-W23-7 } & $9 / 27 / 94$ & BOCIV6 & $\mathbf{N}$ & Conductivity & 257.00 & & umhos $/ \mathrm{cm}$ \\
\hline & $3 / 11 / 96$ & BOHKY1 & $\mathbf{N}$ & Conductivity & 300.00 & - & umhos $/ \mathrm{cm}$ \\
\hline & $6 / 19 / 96$ & B0HL56 & N & Conductivity & 234.00 & & umhos/cm \\
\hline & & B0HL57 & $\mathrm{N}$ & Conductivity & 236.00 & & umhos $/ \mathrm{cm}$ \\
\hline & & B0HLT8 & $\mathbf{y}$ & Conductivity & -242.00 & & umhos $/ \mathrm{cm}$ \\
\hline & & BoHX28 & $\mathrm{N}$ & Conductivity & 235.00 & & umhos $/ \mathrm{cm}$ \\
\hline & $6 / 25 / 96$ & BOHLV3 & $\mathrm{N}$ & Conductivity & 315.00 & & umhos $/ \mathrm{cm}$ \\
\hline & & BOHLV4 & $\mathbf{Y}$ & Conductivity & 326.00 & & umhos $/ \mathrm{cm}$ \\
\hline & & B0HLF6 & $\mathrm{N}$ & Conductivity & 284.00 & $\cdot$ & umhos $/ \mathrm{cm}$ \\
\hline & & B0FDX5 & $\mathbf{N}$ & Conductivity & 326.00 & & umhos $/ \mathrm{cm}$ \\
\hline & & BOHXS47 & $\mathbf{N}$ & Conductivity & 322.00 & & umhos $/ \mathrm{cm}$ \\
\hline & $8 / 27 / 97$ & B0LN18 & $\mathrm{N}$ & Conductivity & 159.50 & - & umhos $/ \mathrm{cm}$ \\
\hline & $6 / 29 / 98$ & BONT40 & $\mathrm{N}$ & Conductivity & 206.00 & & umhos $/ \mathrm{cm}$ \\
\hline & $9 / 16 / 98$ & BOPR4 7 & $\mathbf{N}$ & Conductivity & 181.00 & & umhos $/ \mathrm{cm}$ \\
\hline & $1 / 11 / 99$ & вот9B7 & $\mathbf{N}$ & Conductivity & 182.00 & & umhos $/ \mathrm{cm}$ \\
\hline
\end{tabular}




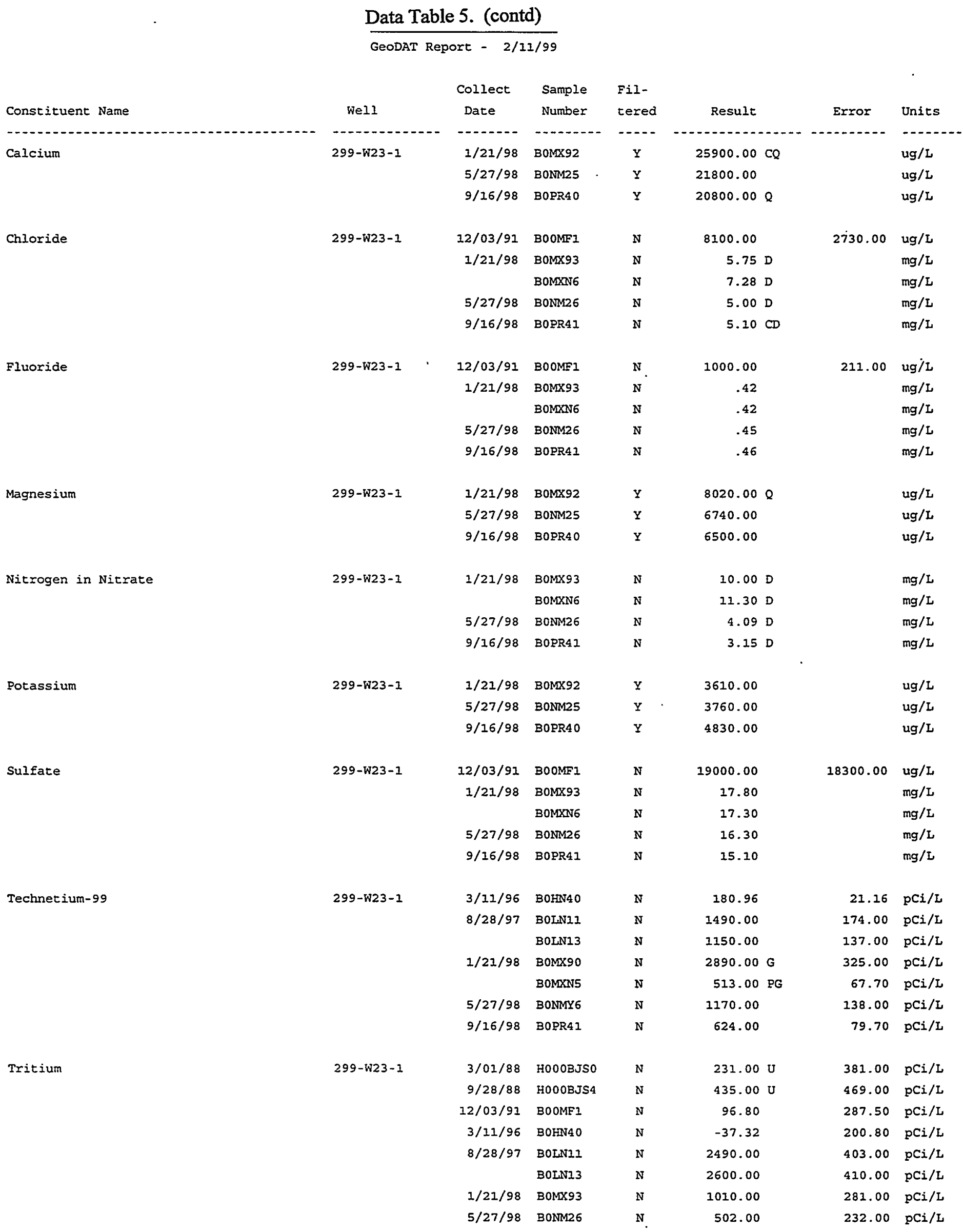


Data Table 5. (contd)

GeoDAT Report - 2/11/99

Constituent Name

Collect Sample Fil-

Well Date Number tered

$\begin{array}{crl}\text { Result } & \text { Error Units } \\ 202.00 \mathrm{U} & 217.00 \mathrm{pCi} / \mathrm{I}\end{array}$

Tritium

299-พ23-1

9/16/98 BOPR41

N

$217.00 \mathrm{pCi} / \mathrm{L}$ 


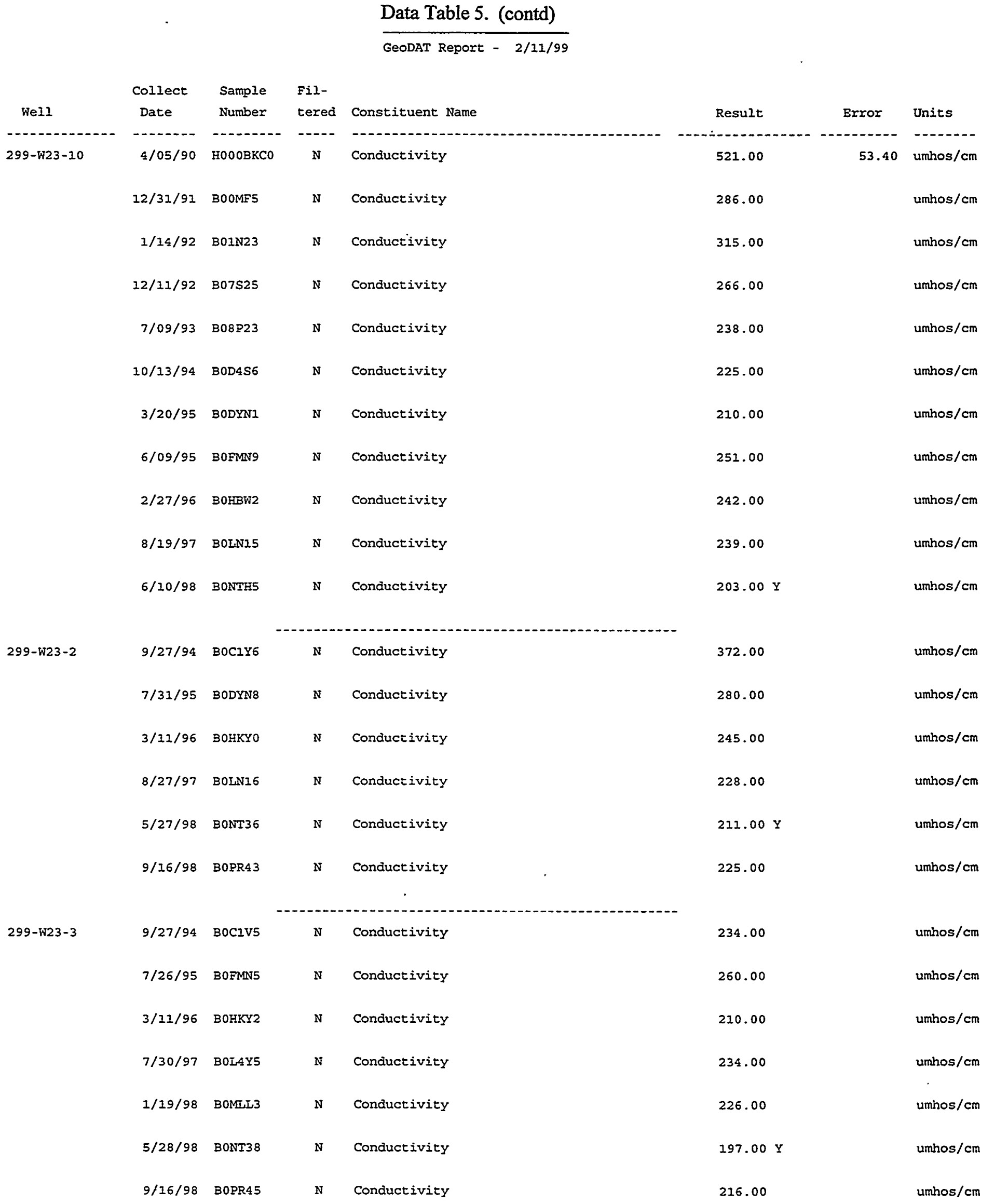




\section{Data Table 5. (contd)}

GeoDAT Report - 2/11/99

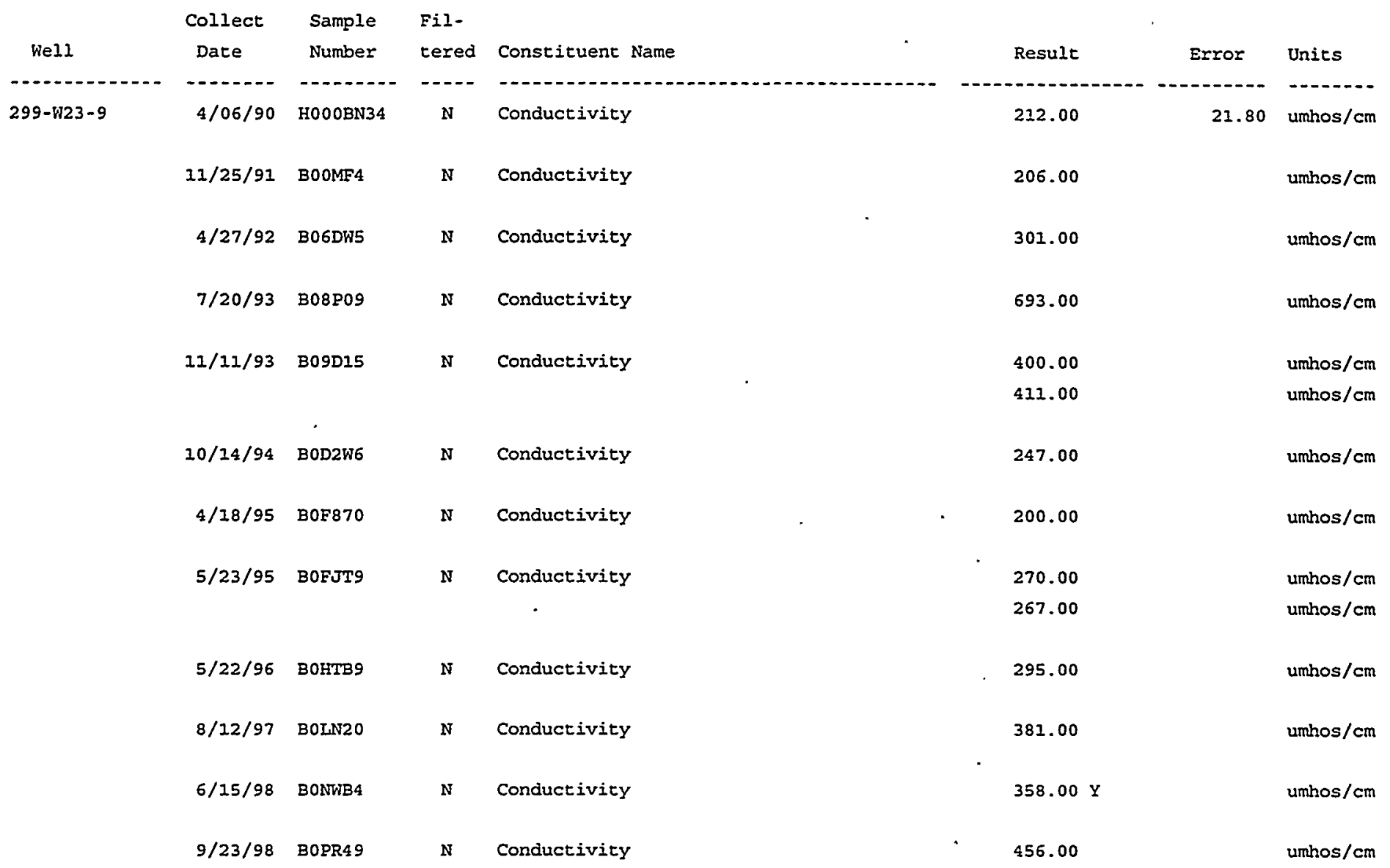


Data Table 6. This table provides data in reference to comment 114.

\begin{tabular}{|c|c|c|c|c|c|c|c|}
\hline Well & $\begin{array}{l}\text { Collect } \\
\text { Date }\end{array}$ & $\begin{array}{l}\text { Sample } \\
\text { Number }\end{array}$ & $\begin{array}{l}\text { Fil- } \\
\text { tered }\end{array}$ & Constituent Name & Result & Error & Units \\
\hline$-1-n-1-n$ & 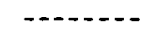 & 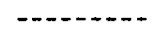 & $-\cdots$ & $\begin{array}{l}n^{\prime} \\
n_{1}\end{array}$ & 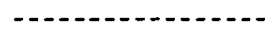 & $----\cdots$ & $-\cdots-$ \\
\hline \multirow[t]{34}{*}{$299-$ W22-39 } & $11 / 14 / 91$ & BOOLT9 & $\mathbf{N}$ & Nitrate & $18000.00 \mathrm{H}$ & 10100.00 & $\mathrm{ug} / \mathrm{L}$ \\
\hline & & & & Technetium-99 & 413.00 & 46.73 & $\mathrm{pCi} / \mathrm{L}$ \\
\hline & $1 / 27 / 92$ & B01QW7 & $\mathrm{N}^{-}$ & Nitrate & 17000.00 & 9570.00 & $\mathrm{ug} / \mathrm{L}$ \\
\hline & & & & Technetium-99 & 359.00 & 40.57 & $\mathrm{pCi} / \mathrm{L}$ \\
\hline & $4 / 23 / 92$ & B067W0 & $\mathrm{N}$ & Nitrate & 18000.00 & 10100.00 & ug/L \\
\hline & & & & Technetium-99 & 453.00 & 50.79 & $\mathrm{pCi} / \mathrm{L}$ \\
\hline & $7 / 10 / 92$ & B071S4 & $\mathrm{N}$ & Nitrate & 19000.00 & 10700.00 & ug/L \\
\hline & & & & Technetium-99 & 554.00 & 61.96 & $\mathrm{pC} i / \mathrm{L}$ \\
\hline & $11 / 24 / 92$ & B07LZ8 & $\mathbf{N}$ & Nitrate & 16000.00 & 9000.00 & $\mathrm{ug} / \mathrm{L}$ \\
\hline & & & & Technetium-99 & 677.00 & 75.33 & $\mathrm{pCi} / \mathrm{L}$ \\
\hline & $3 / 04 / 93$ & B08845 & $\mathbf{N}$ & Nitrate & 19000.00 & 10700.00 & $\mathrm{ug} / \mathrm{L}$ \\
\hline & & & & Technetium-99 & 627.00 & 69.76 & $\mathrm{pCi} / \mathrm{L}$ \\
\hline & $6 / 24 / 93$ & B08N99 & N & Nitrate & 20000.00 & 1730.00 & ug/L \\
\hline & & & & Technetium-99 & 554.00 & 61.78 & $\mathrm{pCi} / \mathrm{L}$ \\
\hline & $3 / 18 / 94$ & B0BJX5 & N & Nitrate & $20000.00 \mathrm{D}$ & & $\mathrm{ug} / \mathrm{L}$ \\
\hline & & & & Technetium-99 & 754.00 & 83.58 & $\mathrm{pC} i / \mathrm{L}$ \\
\hline & $9 / 20 / 94$ & BoCYV9 & N & Technetium-99 & 716.00 & 79.49 & $\mathrm{pCi} / \mathrm{L}$ \\
\hline & & BOCYWO & $\mathbf{N}$ & Technetium-99 & 768.00 & 85.09 & $\mathrm{pCi} / \mathrm{L}$ \\
\hline & $2 / 14 / 95$ & BODQJO & $\mathrm{N}$ & Nitrate & $18000.00 \mathrm{D}$ & 3780.00 & ug/L \\
\hline & & & & Technetium-99 & 829.00 & 91.91 & $\mathrm{pCi} / \mathrm{L}$ \\
\hline & $8 / 09 / 95$ & BOG9RI & $\mathrm{N}$ & Technetium-99 & 796.00 & 88.20 & $\mathrm{pCi} / \mathrm{L}$ \\
\hline & $2 / 08 / 96$ & B0ะ9V9 & $\mathbf{N}$ & Nitrate & $17000.00 \mathrm{D}$ & & $u g / L$ \\
\hline & & & & Technetium-99 & $73.81 \mathrm{~F}$ & 9.71 & $\mathrm{pCi} / \mathrm{L}$ \\
\hline & $8 / 12 / 96$ & B0J6F9 & $\mathbf{N}$ & Technetium-99 & 619.23 & 68.99 & $\mathrm{PCi} / \mathrm{L}$ \\
\hline & $11 / 12 / 96$ & BOJML5 & $\mathbf{N}$ & Nitrogen in Nitrate & $3.33 \mathrm{DQ}$ & & $\mathrm{mg} / \mathrm{L}$ \\
\hline & & & & Technetium-99 & 344.00 & 40.70 & $\mathrm{pCi} / \mathrm{L}$ \\
\hline & $2 / 04 / 97$ & BOKIJ5 & $\mathbf{N}$ & Nitrogen in Nitrate & $2.78 \mathrm{DH}$ & & $\mathrm{mg} / \mathrm{L}$ \\
\hline & & & & Technetium-99 & 306.00 & 36.40 & $\mathrm{pCi} / \mathrm{L}$ \\
\hline & $5 / 13 / 97$ & B0KC84 & $\mathbf{N}$ & Nitrogen in Nitrate & $2.60 \mathrm{D}$ & & $\mathrm{mg} / \mathrm{L}$ \\
\hline & & & & Technetium-99 & 183.00 & 23.10 & $\mathrm{pCi} / \mathrm{L}$ \\
\hline & $8 / 07 / 97$ & B0LD52 & $\mathrm{N}$ & Nitrogen in Nitrate & $2.80 \mathrm{D}$ & & $\mathrm{mg} / \mathrm{L}$ \\
\hline & & & & Technetium-99 & 105.00 & 25.30 & $\mathrm{pCi} / \mathrm{L}$ \\
\hline & $11 / 11 / 97$ & В0M9P4 & $N$ & Nitrogen in Nitrate & $2.80 \mathrm{DQ}$ & & $\mathrm{mg} / \mathrm{L}$ \\
\hline & & & & Technetium-99 & 93.50 & 24.60 & $\mathrm{pCi} / \mathrm{L}$ \\
\hline
\end{tabular}


Data Table 6. (contd)

GeoDAT Repoxt - .2/14/99

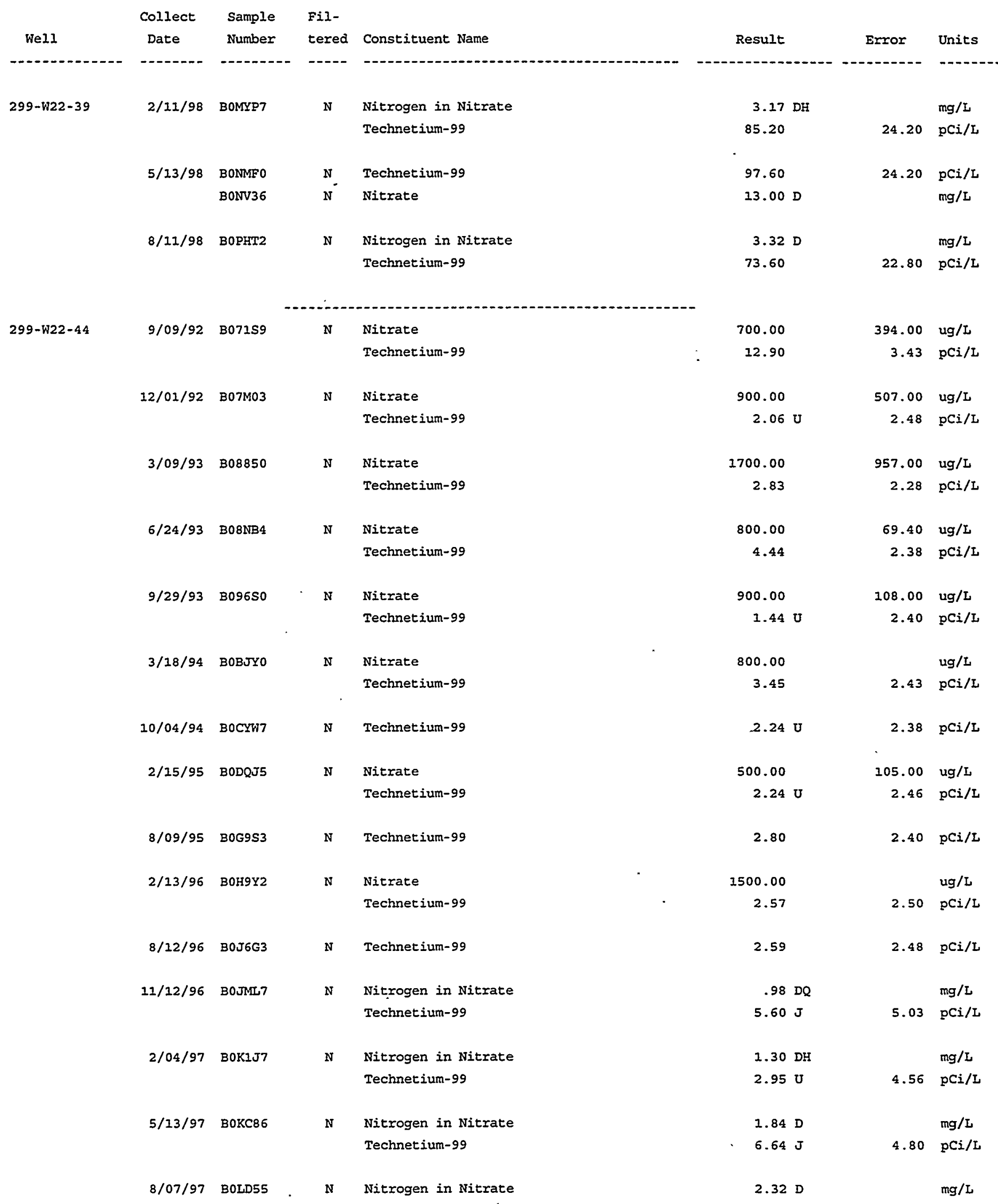




\section{Data Table 6. (contd)}

GeODAT Report - 2/14/99

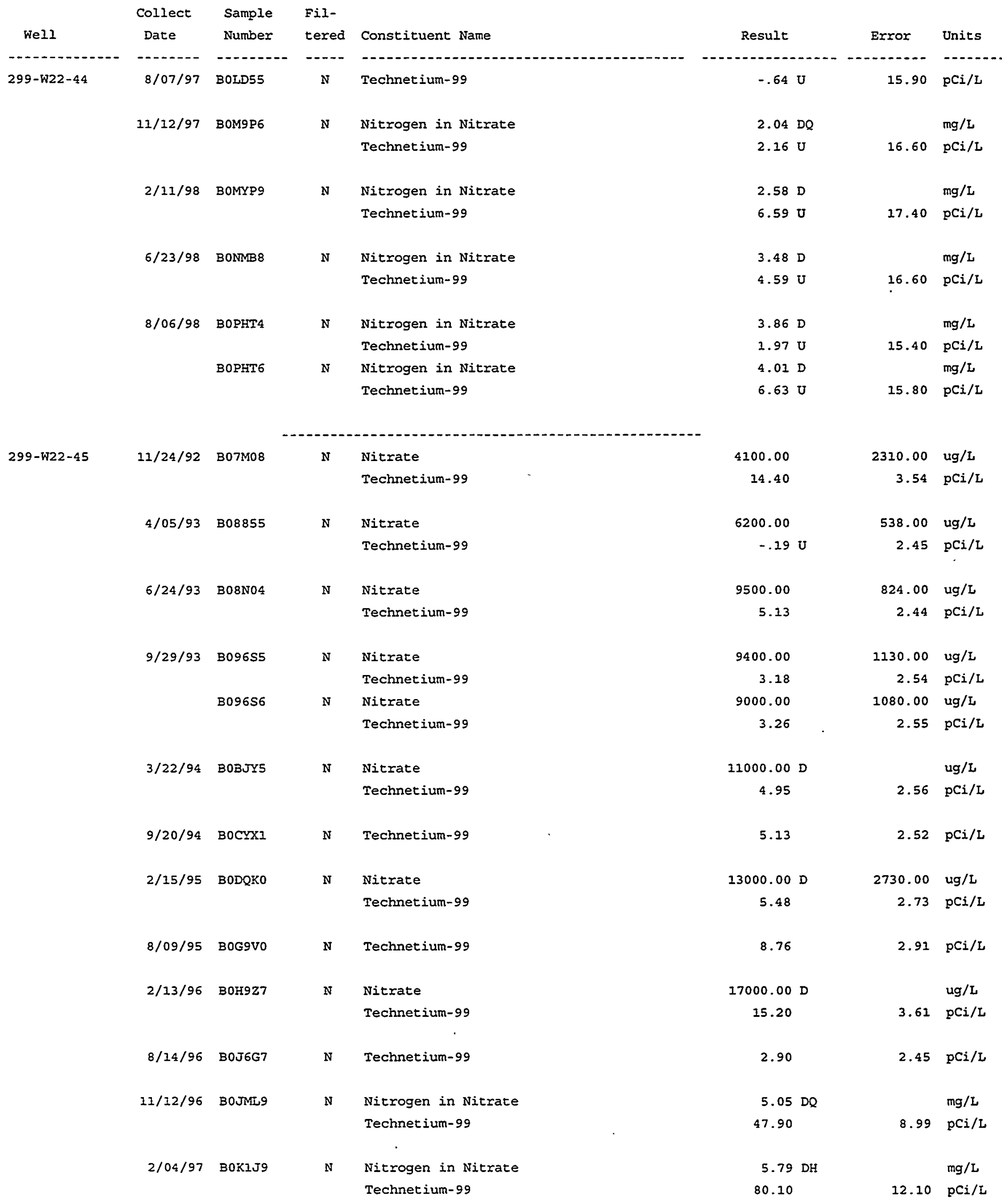


Data Table 6. (contd)

GeoDAT Report - 2/14/99

\begin{tabular}{|c|c|c|c|c|c|c|c|}
\hline Well & $\begin{array}{l}\text { Collect } \\
\text { Date }\end{array}$ & $\begin{array}{l}\text { Sample } \\
\text { Number }\end{array}$ & $\begin{array}{l}\text { Fil- } \\
\text { tered }\end{array}$ & Constituent Name & Resule & Error & Units \\
\hline 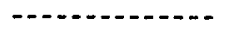 & $\ldots$ & 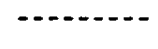 & $\ldots . .$. & 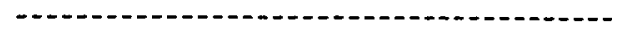 & $\cdots-1-n-1$ & - & $\cdots+-$ \\
\hline \multirow[t]{12}{*}{$299-W 22-45$} & $5 / 20 / 97$ & BOKC88 & $\mathbf{N}$ & Nitrogen in Nitrate & $6.28 \mathrm{D}$ & & $\mathrm{mg} / \mathrm{L}$ \\
\hline & & & & Technetium-99 & 140.00 & 18.50 & $\mathrm{pCi} / \mathrm{I}$ \\
\hline & $8 / 06 / 97$ & B0LD58 & $\mathbf{N}$ & Nitrogen in Nitrate & $7.15 \mathrm{D}$ & & $\mathrm{mg} / \mathrm{L}$ \\
\hline & & & & Technetium-99 & 211.00 & 35.70 & $\mathrm{DCi} / \mathrm{L}$ \\
\hline & $11 / 11 / 97$ & BOM9P8 & $\mathbf{N}$ & Nitrogen in Nitrate & $7.69 \mathrm{DQ}$ & & $\mathrm{mg} / \mathrm{L}$ \\
\hline & & & & Technetium-99 & 256.00 & 41.00 & $\mathrm{DCi} / \mathrm{L}$ \\
\hline & $2 / 09 / 98$ & BOMYRI & $\mathbf{N}$ & Nitrogen in Nitrate & $7.70 \mathrm{D}$ & & $\mathrm{mg} / \mathrm{L}$ \\
\hline & & & & Technetium-99 & 311.00 & 47.00 & $\mathrm{pCi} / \mathrm{L}$ \\
\hline & $5 / 12 / 98$ & BONMCO & $\mathbf{N}$ & Technetium-99 & 427.00 & 59.10 & $\mathrm{pCi} / \mathrm{L}$ \\
\hline & & BoNV23 & $\mathbf{N}$ & Nitrate & $33.00 \mathrm{D}$ & & $\mathrm{mg} / \mathrm{L}$ \\
\hline & $8 / 12 / 98$ & BOPHT8 & $\mathbf{N}$ & Nitrogen in Nitrate & $7.87 \mathrm{D}$ & & $\mathrm{mg} / \mathrm{L}$ \\
\hline & & & & Technetium-99 & 679.00 & 86.20 & $\mathrm{pCi} / \mathrm{L}$ \\
\hline
\end{tabular}

$299-$ W22-46

\begin{abstract}
$4 / 23 / 92 \quad 3067 \times 0$
\end{abstract}
$7 / 10 / 92 \quad$ B071T4

11/23/92 В07M13

$3 / 05 / 93 \quad B 08860$

6/24/93 B08NB9

$3 / 22 / 94 \quad$ BOBJZO

$9 / 20 / 94$ BOCYX5

2/14/95 BODQK5

BODQK6

4/18/95 B0F867

$8 / 09 / 95$ B0G9W6

2/08/96 B0HBO7

$\cdots$

$\mathrm{N}$

Nitrate

Technerium-99

N Nitrate

Technetium-99

N Nitrate

Technetium-99

N Nitrate

Technetium-99

N Nitrate

Technetium-99

N Nitrate

Technetium-99

N Technetium-99

$N$ Nitrate

Technetium-99

N Nitrate

Technetium-99

N Technetium-99

N Technetium-99

N Nitrate

Technetium-99

\begin{tabular}{|c|c|c|}
\hline 22000.00 & 12400.00 & $u g / L$ \\
\hline 884.00 & 97.78 & $\mathrm{pCi} / \mathrm{L}$ \\
\hline 22000.00 & 12400.00 & ug/L \\
\hline 878.00 & 97.24 & $\mathrm{pCi} / \mathrm{L}$ \\
\hline 19000.00 & 10700.00 & ug/L \\
\hline 865.00 & 95.79 & $\mathrm{pCi} / \mathrm{L}$ \\
\hline 21000.00 & 11800.00 & ug/L \\
\hline 611.00 & 68.03 & $\mathrm{pCi} / \mathrm{L}$ \\
\hline 20000.00 & 1730.00 & ug/L \\
\hline 629.00 & 69.92 & $\mathrm{pCi} / \mathrm{L}$ \\
\hline $19000.00 \mathrm{D}$ & & $u g / L$ \\
\hline 646.00 & 71.87 & $\mathrm{pCi} / \mathrm{L}$ \\
\hline 623.00 & 69.45 & $\mathrm{pCi} / \mathrm{I}$ \\
\hline $15000.00 \mathrm{D}$ & 3150.00 & ug/L \\
\hline 559.00 & 62.52 & $\mathrm{pCi} / \mathrm{L}$ \\
\hline $15000.00 \mathrm{D}$ & 3150.00 & ug/I \\
\hline 518.00 & 58.04 & $\mathrm{DCi} / \mathrm{L}$ \\
\hline 437.00 & 49.17 & $p C i / L$ \\
\hline 393.00 & 44.30 & $\mathrm{pCi} / \mathrm{L}$ \\
\hline $11000.00 \mathrm{D}$ & & ug/L \\
\hline 288.07 & 32.95 & $\mathrm{pCi} / \mathrm{L}$ \\
\hline
\end{tabular}




\section{Data Table 6. (contd)}

GeoDAT Report - 2/14/99

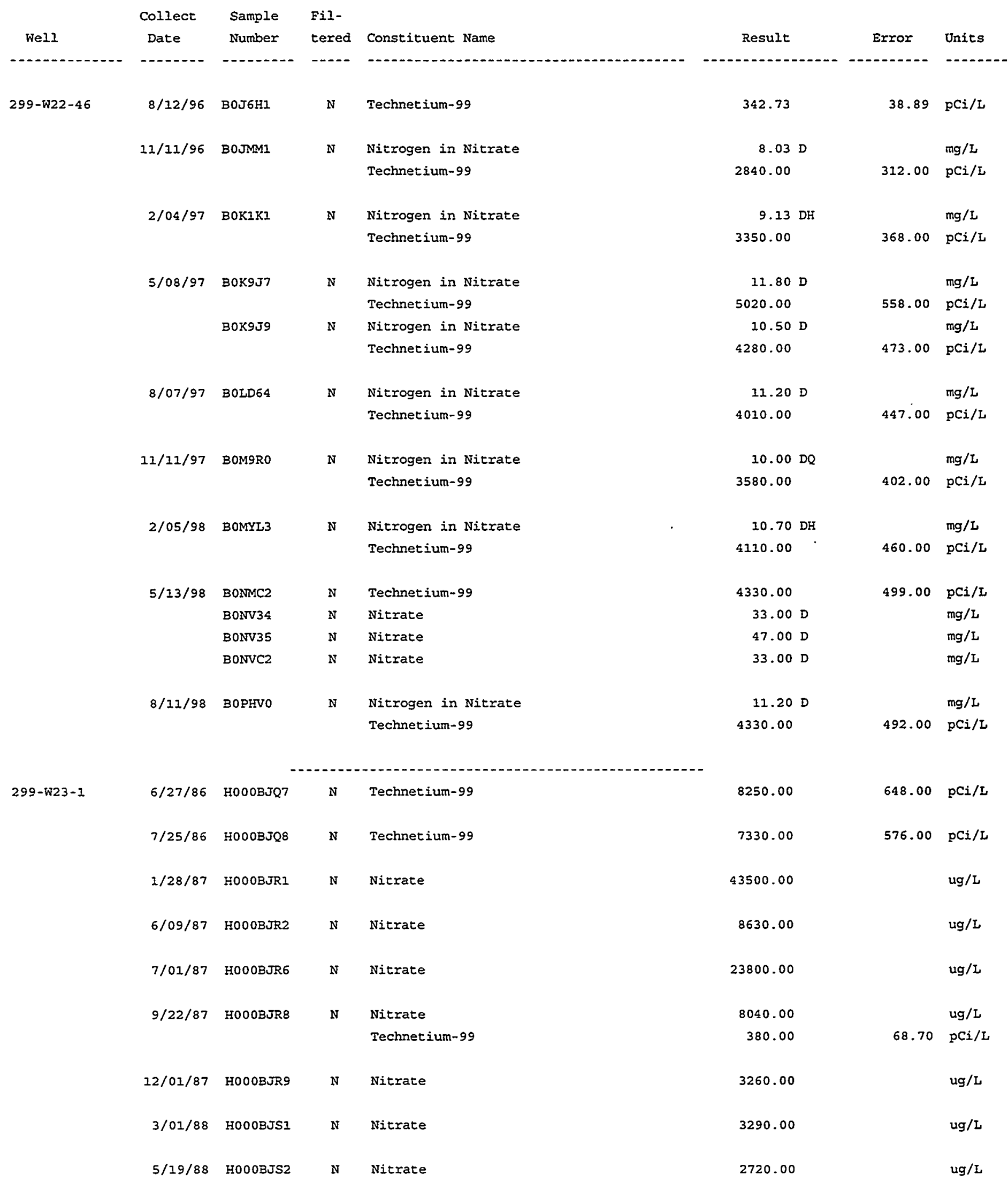




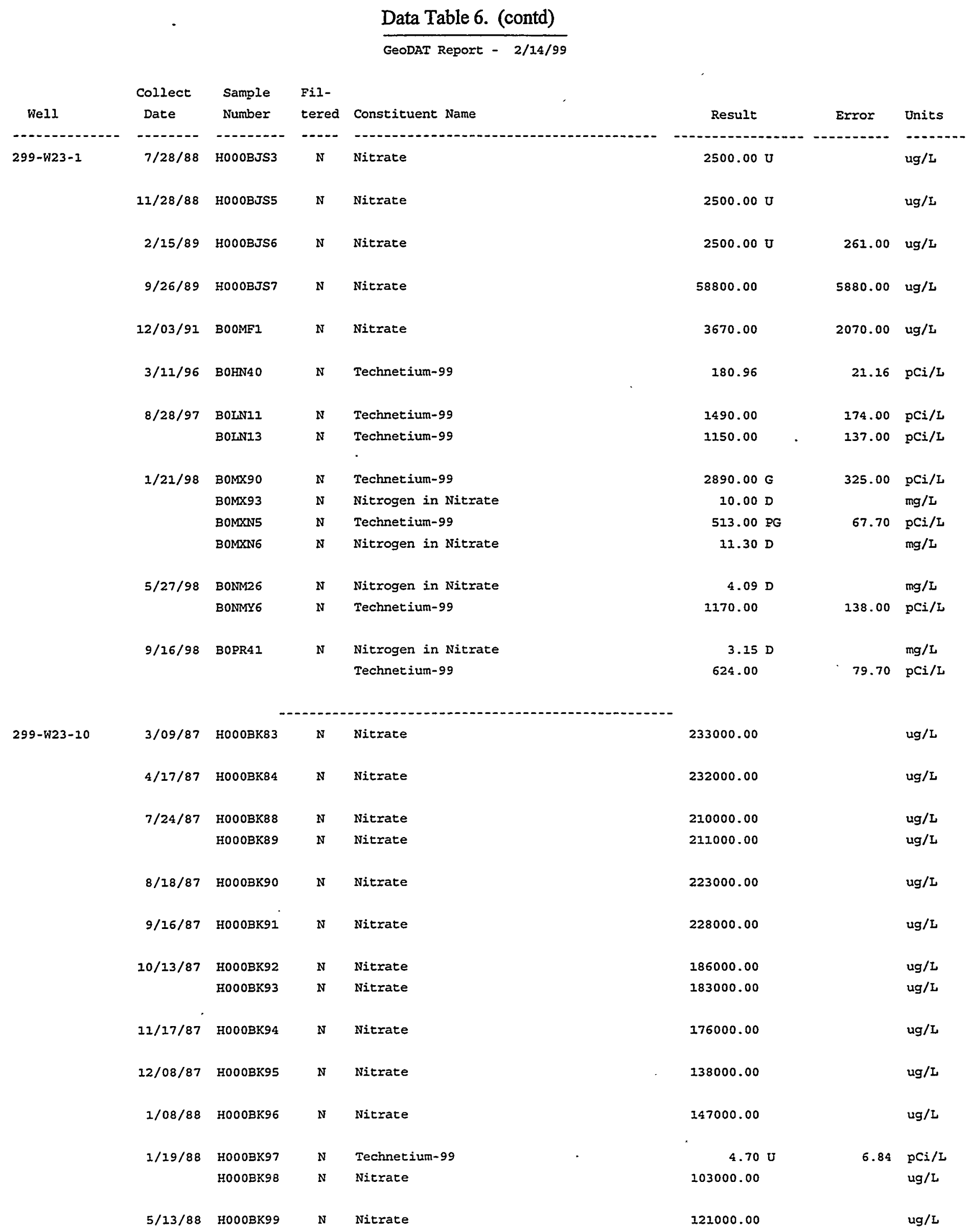




\section{Data Table 6. (contd)}

\section{GeODAT Report - 2/14/99}

\begin{tabular}{|c|c|c|c|c|c|c|c|}
\hline Well & $\begin{array}{l}\text { Collect } \\
\text { Date }\end{array}$ & $\begin{array}{l}\text { Sample } \\
\text { Number }\end{array}$ & $\begin{array}{l}\text { Fil- } \\
\text { tered }\end{array}$ & Constituent Name & Resule & Error & Units \\
\hline$-\cdots+-1-n-1$ & 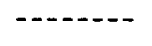 & $-\cdots+\cdots$ & $\cdots$ & 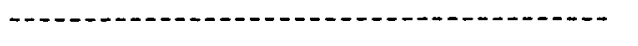 & $n-1-n-1-n-1$ & 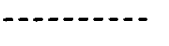 & $\cdots--$ \\
\hline \multirow[t]{20}{*}{ 299-พ23-10 } & $5 / 13 / 88$ & ноООВKB2 & $\mathrm{N}$ & Nitrate & 116000.00 & & $\mathrm{ug} / \mathrm{L}$ \\
\hline & $8 / 18 / 88$ & HOOOBKB3 & $\mathbf{N}$ & Technetium-99 & 19.80 & 9.18 & $\mathrm{pCi} / \mathrm{L}$ \\
\hline & & HOOOBKB4 & $\mathrm{N}$ & Nitrate & 107000.00 & & $\mathrm{ug} / \mathrm{L}$ \\
\hline & & H000BKB6 & $\mathrm{N}$ & Nitrate & 103000.00 & & ug/L \\
\hline & $12 / 12 / 88$ & HОООВКB7 & $\mathrm{N}$ & Nitrate & 101000.00 & & $\mathrm{ug} / \mathrm{L}$ \\
\hline & $1 / 05 / 89$ & HОООВKВ8 & $\mathbf{N}$ & Nitrate & 87100.00 & 8720.00 & ug/I \\
\hline & $2 / 15 / 89$ & НоООВКВ9 & $\mathrm{N}$ & Nitrate & 96800.00. & 9690.00 & $\mathrm{ug} / \mathrm{L}$ \\
\hline & $4 / 05 / 90$ & $\mathrm{HOOOBKCO}$ & N & Nitrate & 158000.00 & 15900.00 & $\mathrm{ug} / \mathrm{L}$ \\
\hline & $12 / 31 / 91$ & BOOMF5 & $\mathrm{N}$ & Technetium-99 & 19.00 & 3.89 & $\mathrm{pCi} / \mathrm{L}$ \\
\hline & $1 / 14 / 92$ & B0IN23 & $N$ & Technetium-99 & 20.10 & 6.22 & $\mathrm{pCi} / \mathrm{L}$ \\
\hline & $12 / 11 / 92$ & B07S25 & $\mathbf{N}$ & Nitrate & 16000.00 & 9000.00 & ug $/ L$ \\
\hline & & & & Technetium-99 & 7.32 & 3.93 & $\mathrm{pCi} / \mathrm{L}$ \\
\hline & $7 / 09 / 93$ & В08P23 & $N$ & Nitrate & 13000.00 & 2130.00 & $\mathrm{ug} / \mathrm{L}$ \\
\hline & & & & Technetium-99 & .98 & 2.39 & $\mathrm{pCi} / \mathrm{L}$ \\
\hline & $10 / 13 / 94$ & BOD4S6 & $\mathrm{N}$ & Nitrate & $12000.00 \mathrm{D}$ & 2520.00 & $\mathrm{ug} / \mathrm{L}$ \\
\hline & & & & Technetium-99 & 2.16 & 2.37 & $\mathrm{pCi} / \mathrm{L}$ \\
\hline & $3 / 20 / 95$ & BODYNI & $\mathrm{N}$ & Nitrate & $12000.00 \mathrm{D}$ & 2520.00 & $\mathrm{ug} / \mathrm{L}$ \\
\hline & $2 / 27 / 96$ & вонвพ2 & $\mathrm{N}$ & Nitrate & $14000.00 \mathrm{D}$ & 2940.00 & $\mathrm{ug} / \mathrm{L}$ \\
\hline & $8 / 19 / 97$ & B0IN15 & $\mathrm{N}$ & Nitrogen in Nitrate & $3.08 \mathrm{D}$ & & $\mathrm{mg} / \mathrm{L}$ \\
\hline & $6 / 10 / 98$ & BONTH5 & $\mathrm{N}$ & Nitrogen in Nitrate & $2.97 \mathrm{DQ}$ & & $\mathrm{mg} / \mathrm{L}$ \\
\hline \multirow[t]{10}{*}{$299-$ พ23-13 } & $10 / 03 / 91$ & BOOLV3 & $\mathbf{N}$ & Nitrate & 9200.00 & & $\mathrm{ug} / \mathrm{L}$ \\
\hline & & & & Technetium-99 & -.21 & 2.11 & $\mathrm{pCi} / \mathrm{L}$ \\
\hline & $1 / 27 / 92$ & B010X2 & $\mathrm{N}$ & Nitrate & 7700.00 & 4330.00 & $\mathrm{ug} / \mathrm{L}$ \\
\hline & & & & Technerium-99 & 13.70 & 3.23 & $\mathrm{pCi} / \mathrm{L}$ \\
\hline & $4 / 23 / 92$ & $3067 \times 5$ & $\mathrm{~N}$ & Nitrate & 7900.00 & 4450.00 & $u g / L$ \\
\hline & & & & Technetium-99 & 2.17 & 2.30 & $\mathrm{pCi} / \mathrm{L}$ \\
\hline & $7 / 10 / 92$ & B071T9 & $\mathrm{N}$ & Nitrate & 11000.00 & 6190.00 & $\mathrm{ug} / \mathrm{L}$ \\
\hline & & & & Technetium-99 & .10 & 2.28 & $\mathrm{pCi} / \mathrm{L}$ \\
\hline & $11 / 23 / 92$ & B07M38 & $\mathrm{N}$ & Nitrate & 7700.00 & 4330.00 & $\mathrm{ug} / \mathrm{L}$ \\
\hline & & & & Technetium-99 & $-.05 \mathrm{U}$ & 2.28 & $\mathrm{pCi} / \mathrm{L}$ \\
\hline
\end{tabular}




\section{Data Table 6. (contd)}

\section{GeoDAT Report - 2/14/99}

\begin{tabular}{|c|c|c|c|c|c|c|c|}
\hline Well & $\begin{array}{l}\text { Collect } \\
\text { Date }\end{array}$ & $\begin{array}{l}\text { Sample } \\
\text { Number }\end{array}$ & $\begin{array}{l}\text { Fil- } \\
\text { Eered }\end{array}$ & Constituent Name & Result & Error & Units \\
\hline \multirow{14}{*}{ 299-W23-13 } & $3 / 04 / 93$ & B087Q0 & 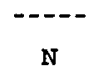 & Nitrate & 8000.00 & 4500.00 & $\mathrm{ug} / \mathrm{L}$ \\
\hline & $6 / 24 / 93$ & B08MX4 & $\mathrm{N}$ & Nitrate & 6500.00 & 564.00 & $u g / L$ \\
\hline & & & & Technetium-99 & $.91 \mathrm{U}$ & 2.10 & $\mathrm{pCi} / \mathrm{L}$ \\
\hline & $3 / 18 / 94$ & B0BJZ5 & N & Nitrate & 5500.00 & & $u g / L$ \\
\hline & & & & Technetium-99 & $.46 \mathrm{U}$ & 2.19 & $\mathrm{pCi} / \mathrm{L}$ \\
\hline & $9 / 20 / 94$ & BoCYX9 & $\mathbf{N}$ & Technetium-99 & $.42 \mathrm{U}$ & 2.32 & $\mathrm{pCi} / \mathrm{L}$ \\
\hline & $2 / 14 / 95$ & BODQL5 & $\mathrm{N}$ & Nitrate & 5800.00 & 1220.00 & $u g / L$ \\
\hline & & & & Technetium-99 & $.64 \mathrm{U}$ & 2.34 & $\dot{\mathrm{p} C i} / \mathrm{L}$ \\
\hline & $8 / 04 / 95$ & BoG9X9 & N & Technerium-99 & 8.61 & 2.87 & $\mathrm{pCi} / \mathrm{L}$ \\
\hline & $2 / 07 / 96$ & B0HB17 & N & Nitrate & 2700.00 & & ug/L \\
\hline & & & & Technetium-99 & $1.74 \mathrm{U}$ & 2.38 & $\mathrm{pCi} / \mathrm{L}$ \\
\hline & $8 / 08 / 96$ & B0J6H5 & $\mathrm{N}$ & Technetium-99 & .15 & 2.21 & $\mathrm{pCi} / \mathrm{L}$ \\
\hline & $11 / 07 / 96$ & В0ЛММ3 & N & Nitrogen in Nitrate & .56 & & $\mathrm{mg} / \mathrm{L}$ \\
\hline & & & & Technetium-99 & .840 & 4.56 & $\mathrm{pCi} / \mathrm{L}$ \\
\hline & $2 / 06 / 97$ & B0K1K3 & N & Nitrogen in Nitrate & $.57 \mathrm{H}$ & & $\mathrm{mg} / \mathrm{L}$ \\
\hline . & & & & Technetium-99 & $1.32 \mathrm{U}$ & 4.63 & $\mathrm{pCi} / \mathrm{L}$ \\
\hline & $5 / 07 / 97$ & В0КС92 & $\mathrm{N}$ & Nitrogen in Nitrate & .54 & & $\mathrm{mg} / \mathrm{L}$ \\
\hline & & & & Technetium-99 & $1.90 \mathrm{U}$ & 4.52 & $\mathrm{pCi} / \mathrm{L}$ \\
\hline & $8 / 07 / 97$ & BOLD67 & N & Nitrogen in Nitrate & .56 & & $\mathrm{mg} / \mathrm{L}$ \\
\hline & & & & Technetium-99 & $.27 \mathrm{U}$ & 16.00 & $\mathrm{pCi} / \mathrm{L}$ \\
\hline & $11 / 11 / 97$ & BOM9J8 & N & Nitrogen in Nitrate & .570 & & $\mathrm{mg} / \mathrm{L}$ \\
\hline & & & & Technetium-99 & $.80 \mathrm{U}$ & 16.50 & $p \mathrm{C} i / \mathrm{L}$ \\
\hline & $2 / 05 / 98$ & BOMYL5 & $\mathbf{N}$ & Nitrogen in Nitrate & $.53 \mathrm{H}$ & & $\mathrm{mg} / \mathrm{L}$ \\
\hline & & & & Technetium-99 & $10.60 \mathrm{U}$ & 17.70 & $\mathrm{pCi} / \mathrm{L}$ \\
\hline & $5 / 11 / 98$ & BONMC4 & $\mathrm{N}$ & Technetium-99 & $5.27 \mathrm{U}$ & 17.00 & $\mathrm{pCi} / \mathrm{L}$ \\
\hline & & BoNV24 & $\mathrm{N}$ & Nitrate & 2.30 & & $\mathrm{mg} / \mathrm{L}$ \\
\hline & $8 / 06 / 98$ & B0PHV2 & $\mathbf{N}$ & Nitrogen in Nitrate & .52 & & $\mathrm{mg} / \mathrm{L}$ \\
\hline & & & & Technetium-99 & $.95 \mathrm{U}$ & 15.40 & $\mathrm{pCi} / \mathrm{L}$ \\
\hline $299-$ W23-14 & $10 / 09 / 91$ & B00LV7 & $\mathbf{N}$ & Nitrate & 2800.00 & & $\mathrm{ug} / \mathrm{L}$ \\
\hline & & & & Technetium-99 & 8.91 & 2.87 & $\mathrm{pCi} / \mathrm{L}$ \\
\hline & $1 / 27 / 92$ & $3010 \times 7$ & $\mathbf{N}$ & Nitrate & 3200.00 & 1800.00 & ug $/ \mathrm{L}$ \\
\hline & & & & Technetium-99 & 4.14 & 2.35 & $\mathrm{pCi} / \mathrm{L}$ \\
\hline
\end{tabular}




\section{Data Table 6. (contd)}

GeoDAT Report - 2/14/99

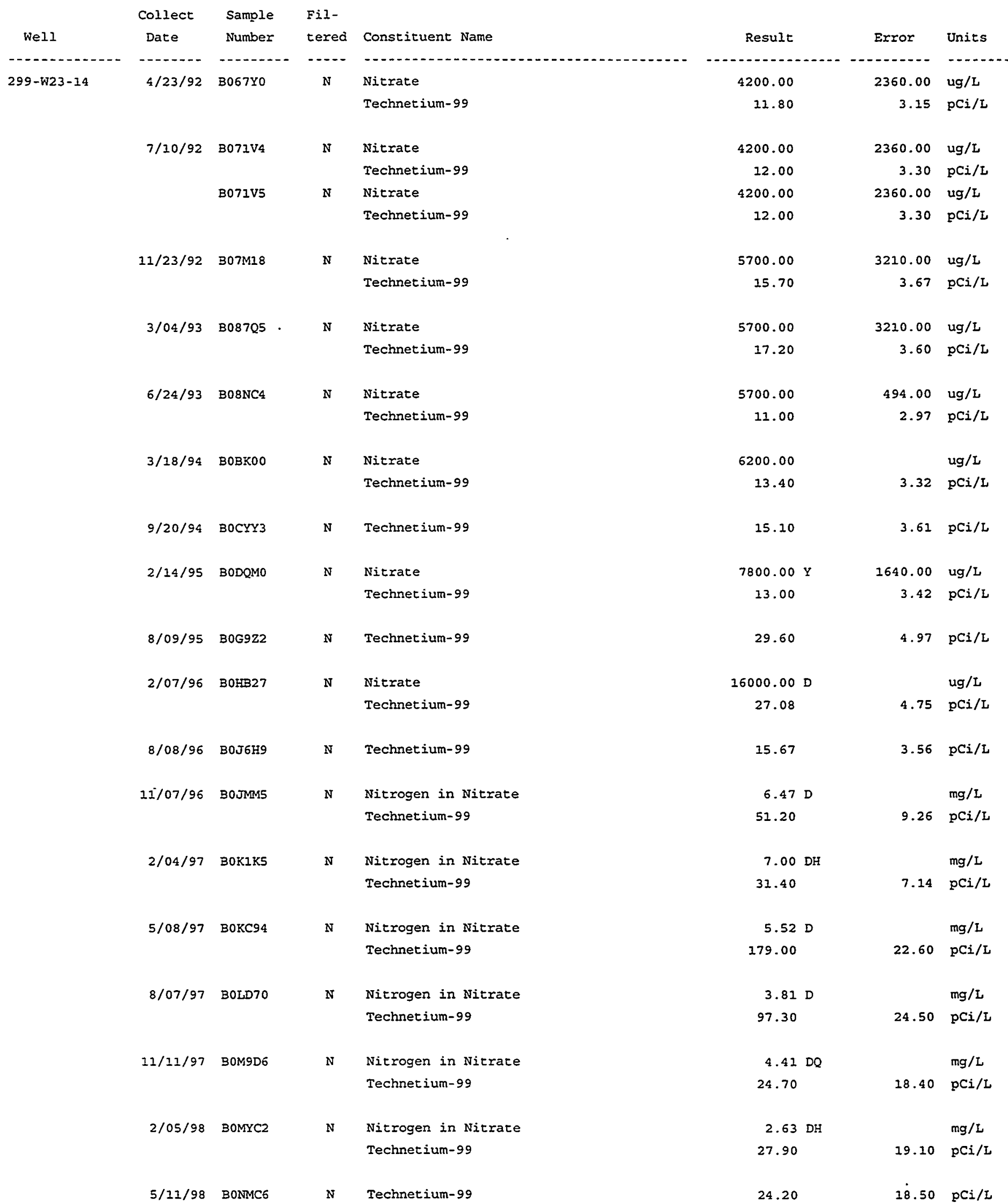

B.116 


\section{Data Table 6. (contd)}

\section{GeODAT Report - 2/14/99}

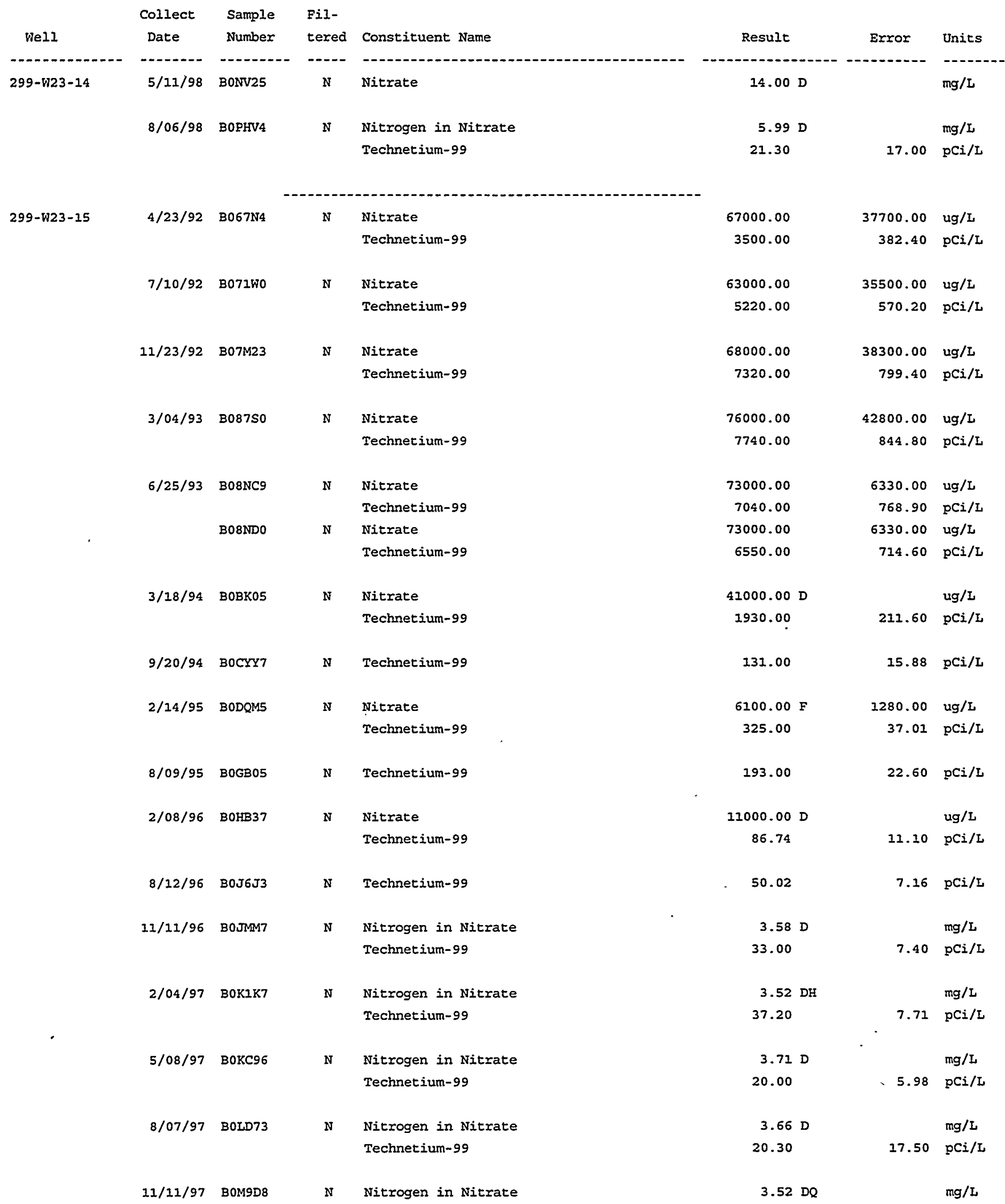




\section{Data Table 6. (contd)}

GeoDAT Report - 2/14/99

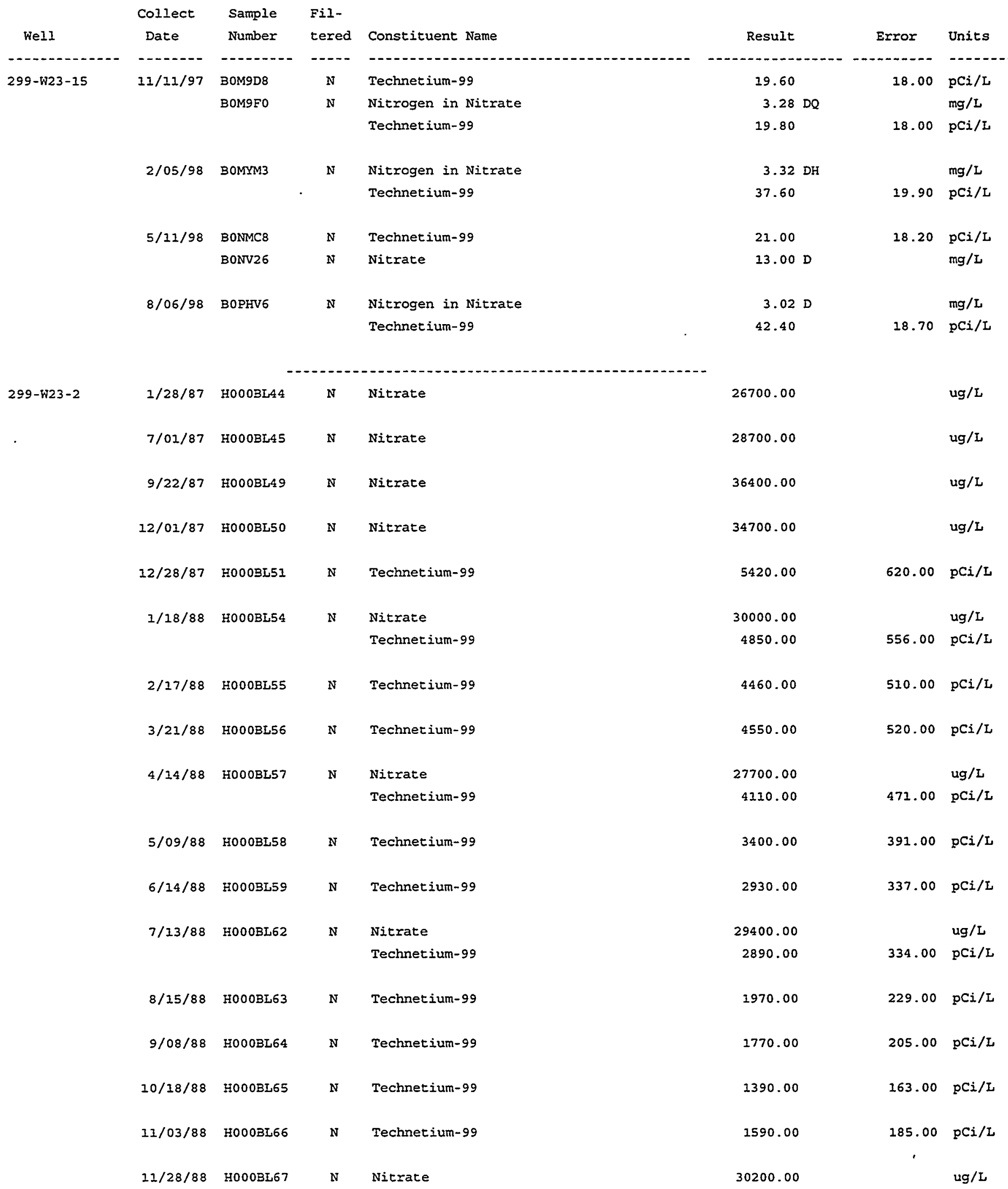


Data Table 6. (contd)

GeoDAT Report - 2/14/99

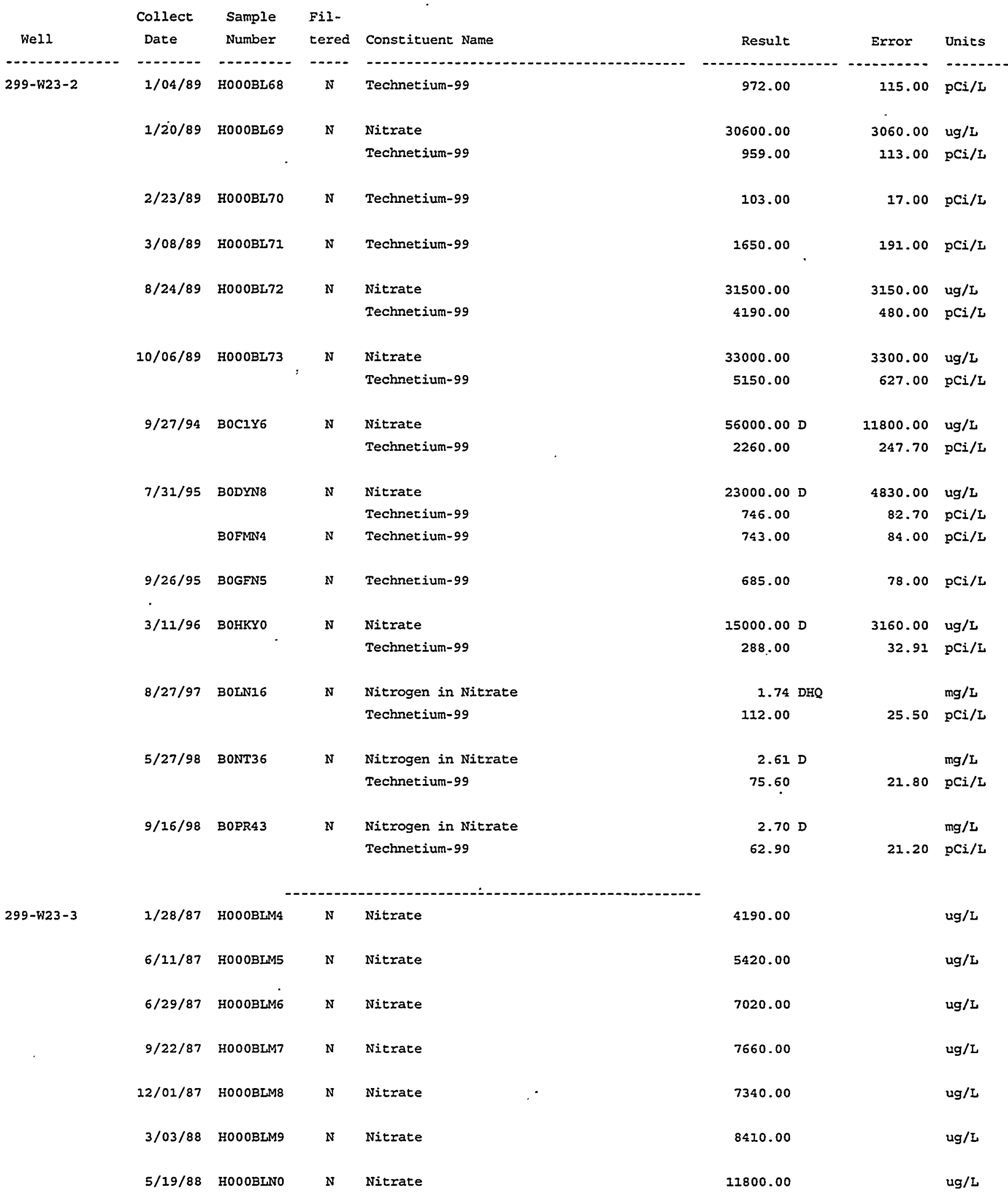




\begin{tabular}{|c|c|c|c|c|c|c|c|}
\hline \multirow[b]{3}{*}{ Well } & \multicolumn{4}{|r|}{ Data Table 6. (contd) } & \multirow[b]{3}{*}{ Result } & \multirow[b]{3}{*}{ Error } & \multirow[b]{3}{*}{ Units } \\
\hline & & & & GeoDAT Report - 2/14/99 & & & \\
\hline & $\begin{array}{l}\text { Collect } \\
\text { Date }\end{array}$ & $\begin{array}{l}\text { Sample } \\
\text { Number }\end{array}$ & $\begin{array}{l}\text { Fil- } \\
\text { tered }\end{array}$ & Constituent Name & & & \\
\hline$-2--1-2-1-2$ & $-\cdots-1$ & 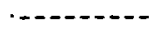 & $-\cdots$ & - & 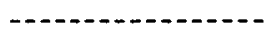 & - & $\ldots \ldots$ \\
\hline \multirow[t]{20}{*}{$299-$ พ23-3 } & $7 / 28 / 88$ & HOOOBLN1 & $\mathbf{N}$ & Nitrace & 14300.00 & & $\mathrm{ug} / \mathrm{L}$ \\
\hline & $11 / 28 / 88$ & HOOOBLN2 & $\mathbf{N}$ & Nitrate & 19500.00 & & $\mathrm{ug} / \mathrm{L}$ \\
\hline & $2 / 15 / 89$ & HOOOBLN3 & $\mathrm{N}$ & Nitrate & 21500.00 & 2250.00 & ug/L \\
\hline & $9 / 26 / 89$ & HOOOBLN4 &.$^{N}$ & Nitrate & 17900.00 & 1790.00 & $\mathrm{ug} / \mathrm{L}$ \\
\hline & $1 / 04 / 91$ & H0007068 & $\mathbf{N}$ & Nitrate & 11.00 & & $\mathrm{mg} / \mathrm{L}$ \\
\hline & $9 / 27 / 94$ & Bocivs & N & Nitrate & $14000.00 \mathrm{D}$ & 2940.00 & $\mathrm{ug} / \mathrm{L}$ \\
\hline & & & & Technetium-99 & 523.00 & 58.44 & $\mathrm{pCi} / \mathrm{L}$ \\
\hline & $7 / 26 / 95$ & BODYN7 & $\mathbf{N}$ & Nitrate & $17000.00 \mathrm{D}$ & 3570.00 & $\mathrm{ug} / \mathrm{L}$ \\
\hline & & & & Technetium-99 & 347.00 & 39.30 & $\mathrm{pCi} / \mathrm{L}$ \\
\hline & & BOFMN5 & $\mathrm{N}$ & Technetium-99 & 328.00 & 39.00 & $\mathrm{pCi} / \mathrm{L}$ \\
\hline & $9 / 27 / 95$ & BOGFN6 & $\mathbf{N}$ & Technetium-99 & 338.00 & 40.30 & $\mathrm{pCi} / \mathrm{L}$ \\
\hline & $3 / 11 / 96$ & BOHKY2 & $\mathbf{N}$ & Technetium-99 & 187.12 & 21.94 & $\mathrm{pCi} / \mathrm{I}$ \\
\hline & $7 / 30 / 97$ & BOL4Y5 & $\mathbf{N}$ & Nitrogen in Nitrate & $1.95 \mathrm{DH}$ & & $\mathrm{mg} / \mathrm{L}$ \\
\hline & & BOLBC9 & $\mathrm{N}$ & Technetium-99 & 62.60 & 20.60 & $\mathrm{pCi} / \mathrm{L}$ \\
\hline & $1 / 19 / 98$ & BOMLL3 & N & Nitrogen in Nitrate & $1.85 \mathrm{D}$ & & $m g / L$ \\
\hline & & & & Technetium-99 & 73.60 & 27.10 & $\mathrm{pCi} / \mathrm{L}$ \\
\hline & $5 / 28 / 98$ & BONT38 & $\mathrm{N}$ & Nitrogen in Nitrate & $1.58 \mathrm{DQ}$ & & $\mathrm{mg} / \mathrm{L}$ \\
\hline & & & & Technetium-99 & 38.70 & 18.50 & $\mathrm{pCi} / \mathrm{L}$ \\
\hline & $9 / 16 / 98$ & BOPR45 & $\mathrm{N}$ & Nitrogen in Nitrate & $1.57 \mathrm{D}$ & & $\mathrm{mg} / \mathrm{L}$ \\
\hline & & & & Technetium-99 & 46.30 & 29.70 & $\mathrm{pCi} / \mathrm{L}$ \\
\hline \multirow[t]{9}{*}{$299-$ W23-4 } & $11 / 25 / 86$ & H०00ВM96 & $\mathrm{N}$ & Nitrate & 2680.00 & & $u g / L$ \\
\hline & $1 / 26 / 87$ & HоОовм99 & $\mathbf{N}$ & Nitrate & 592.00 & & $\mathrm{ug} / \mathrm{L}$ \\
\hline & $9 / 23 / 87$ & Н00ОВМВо & $\mathrm{N}$ & Nitrate & $2500.00 \mathrm{U}$ & & ug/L \\
\hline & $2 / 22 / 88$ & HOOOBMB4 & $\mathrm{N}$ & Nitrate & 9730.00 & & $u g / L$ \\
\hline & $5 / 17 / 88$ & HOOOBMB5 & $\mathrm{N}$ & Nitrate & 8940.00 & & $u g / L$ \\
\hline & $6 / 09 / 88$ & HOOOBMB6 & $\mathrm{N}$ & Nitrate & 8990.00 & & $\mathrm{ug} / \mathrm{L}$ \\
\hline & $7 / 25 / 88$ & HOOOBMB8 & $\mathrm{N}$ & Nitrace & 7190.00 & & $\mathrm{ug} / \mathrm{L}$ \\
\hline & $9 / 08 / 88$ & H000BMB & $\mathrm{N}$ & Nitrate & 6570.00 & & $\mathrm{ug} / \mathrm{L}$ \\
\hline & $10 / 18 / 88$ & Но0овмС0 & $\mathbf{N}$ & Nitrate & 5300.00 & & $\mathrm{ug} / \mathrm{L}$ \\
\hline
\end{tabular}


Data Table 6. (contd)

GeoDAT Report - 2/14/99

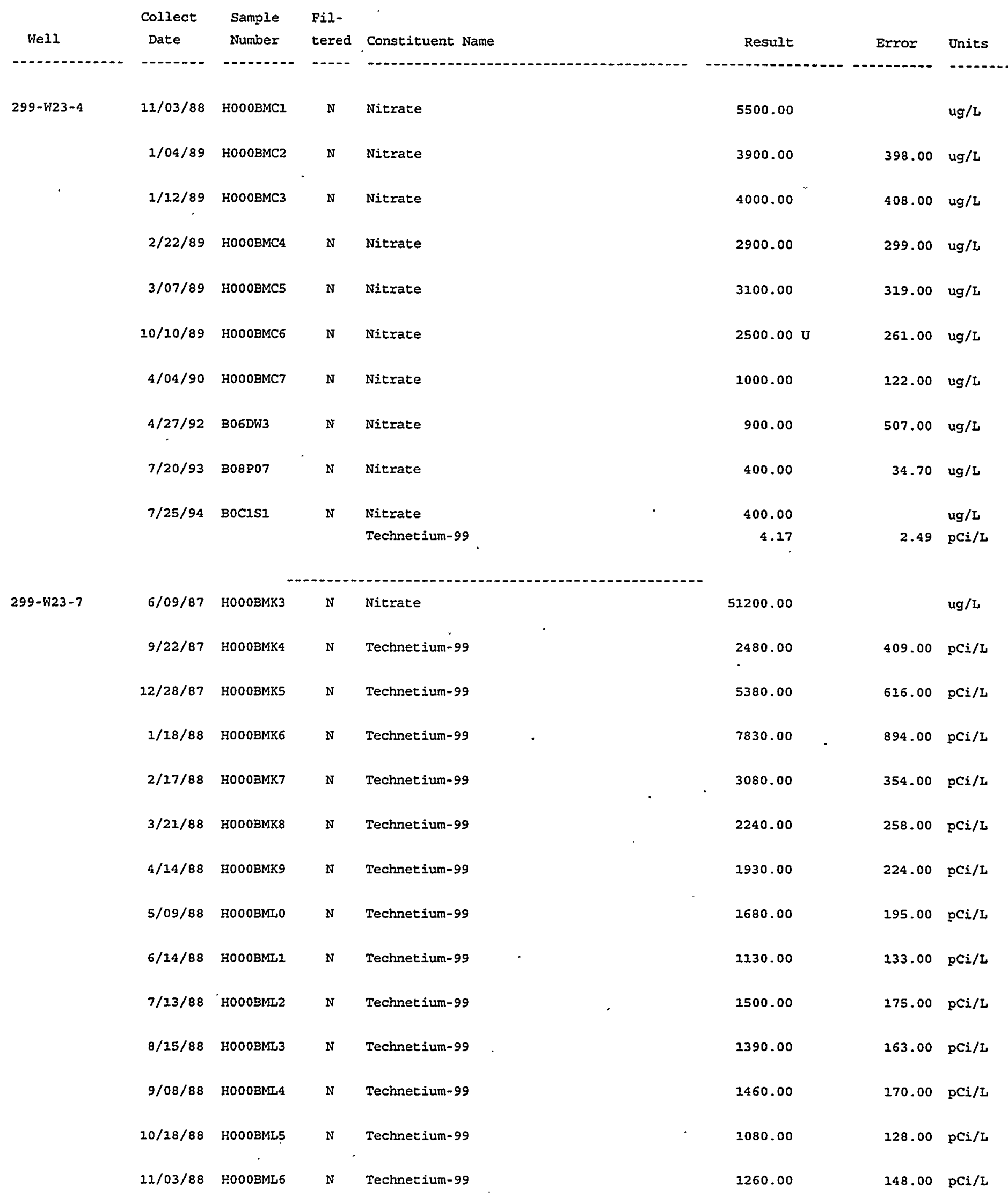




\section{Data Table 6. (contd)}

GeODAT Report - 2/14/99

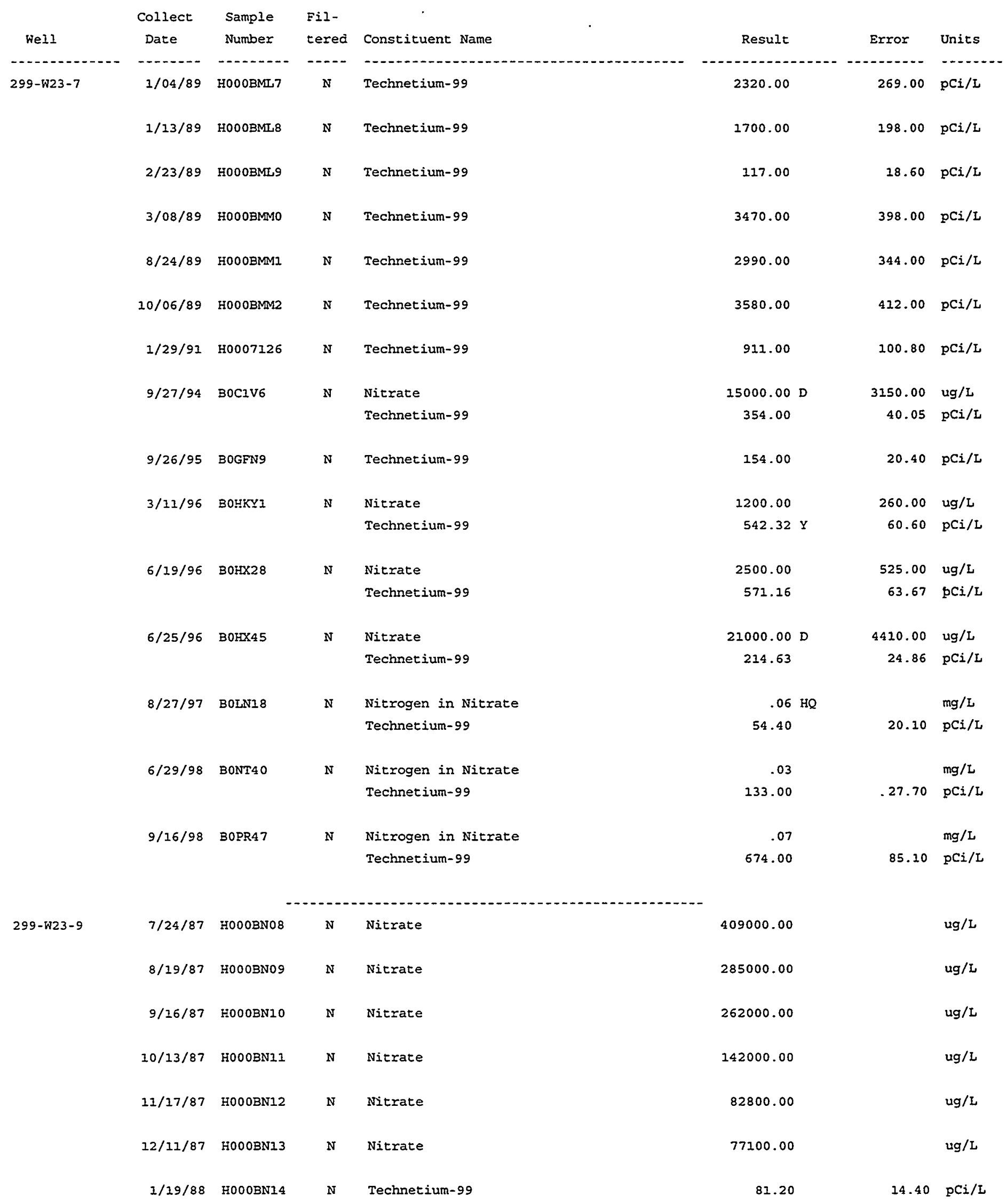




\section{Data Table 6. (contd)}

GeoDAT Report - 2/14/99

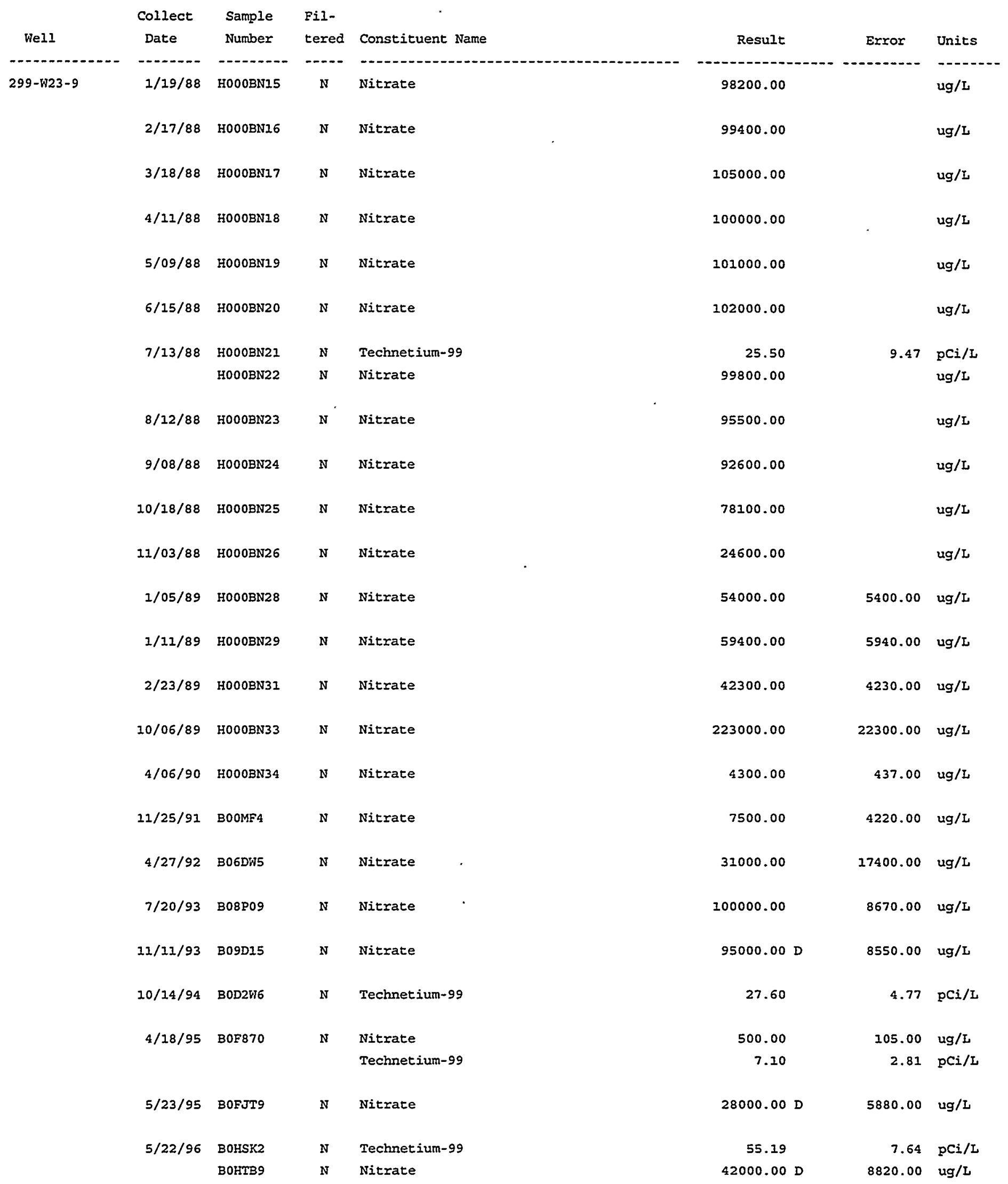




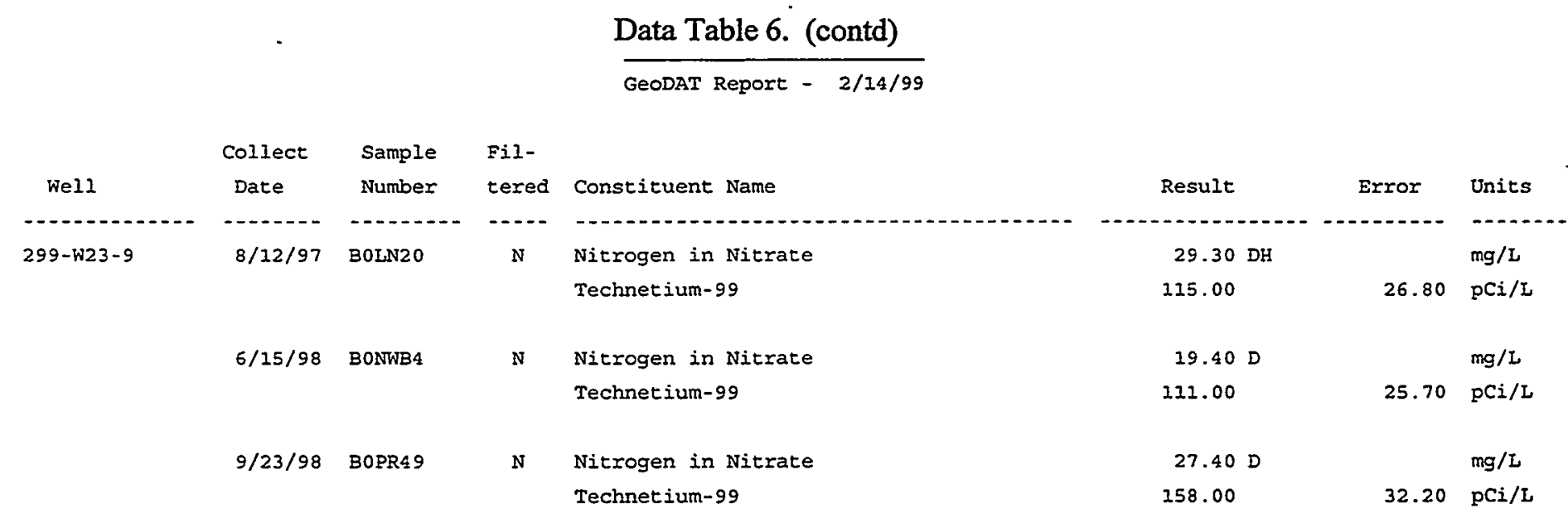


Data Table 7. This table provides data in reference to comment 117.

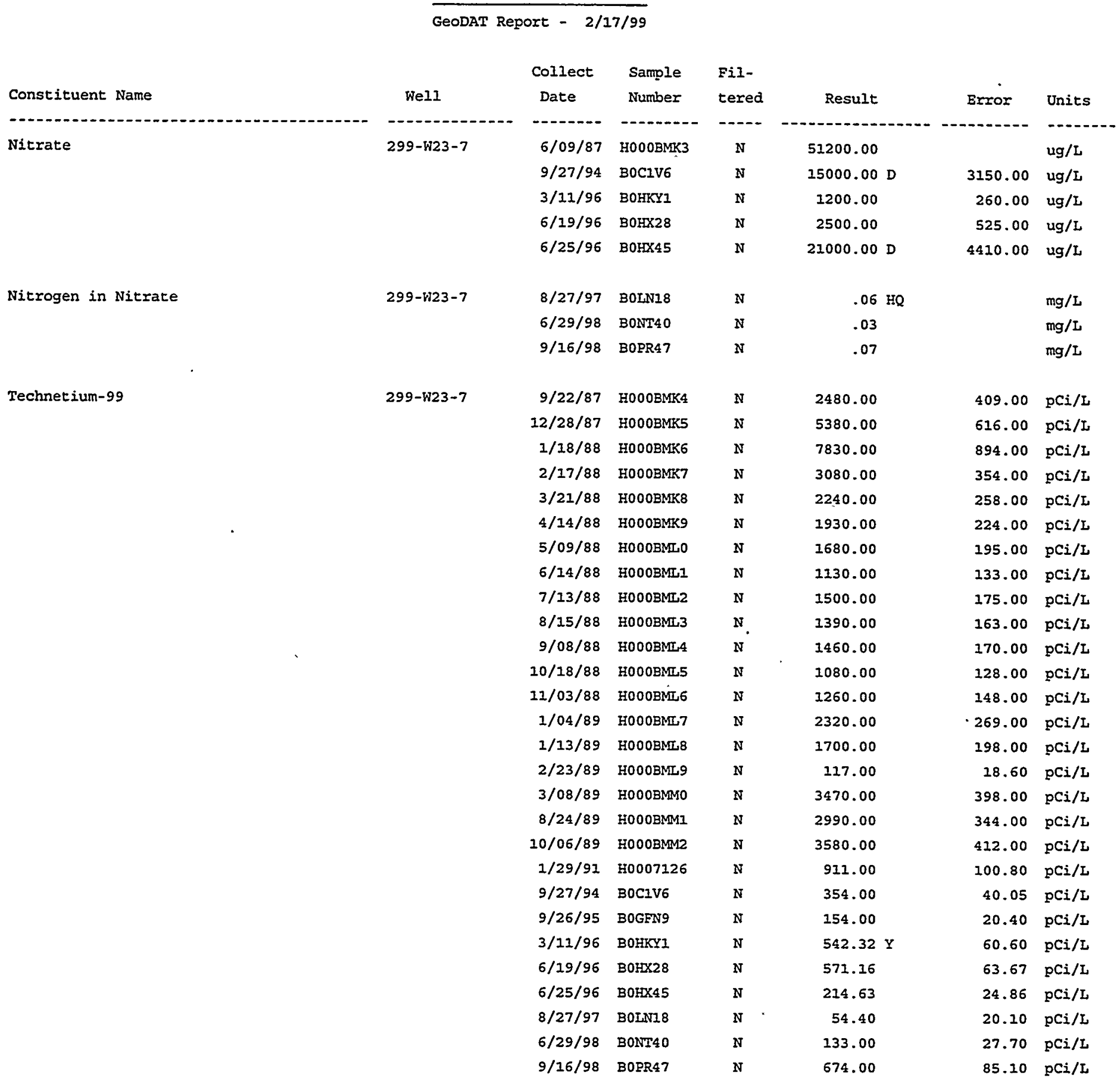


Data Table 8. This table provides data in reference to comment 120.

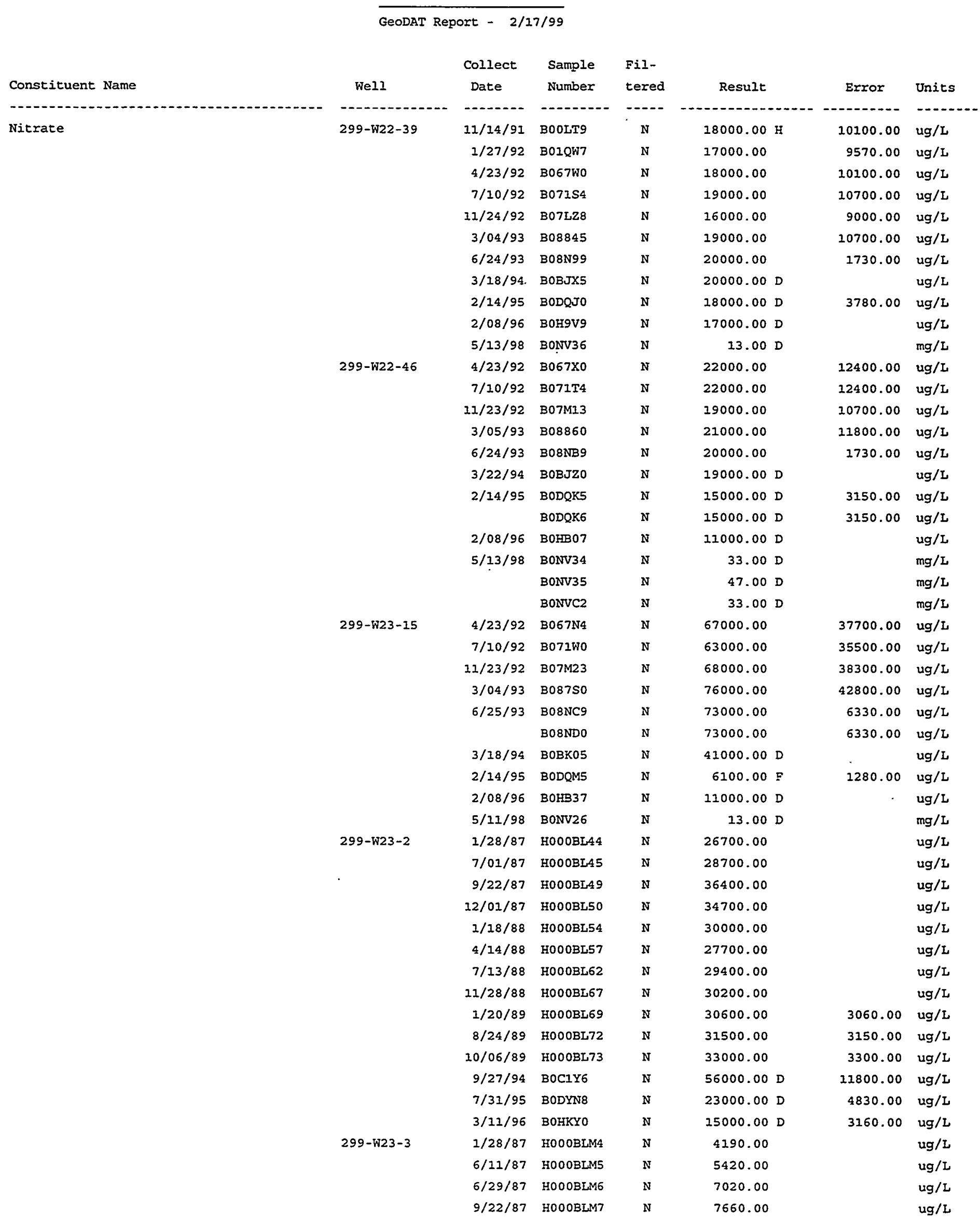


Data Table 8. (contd)

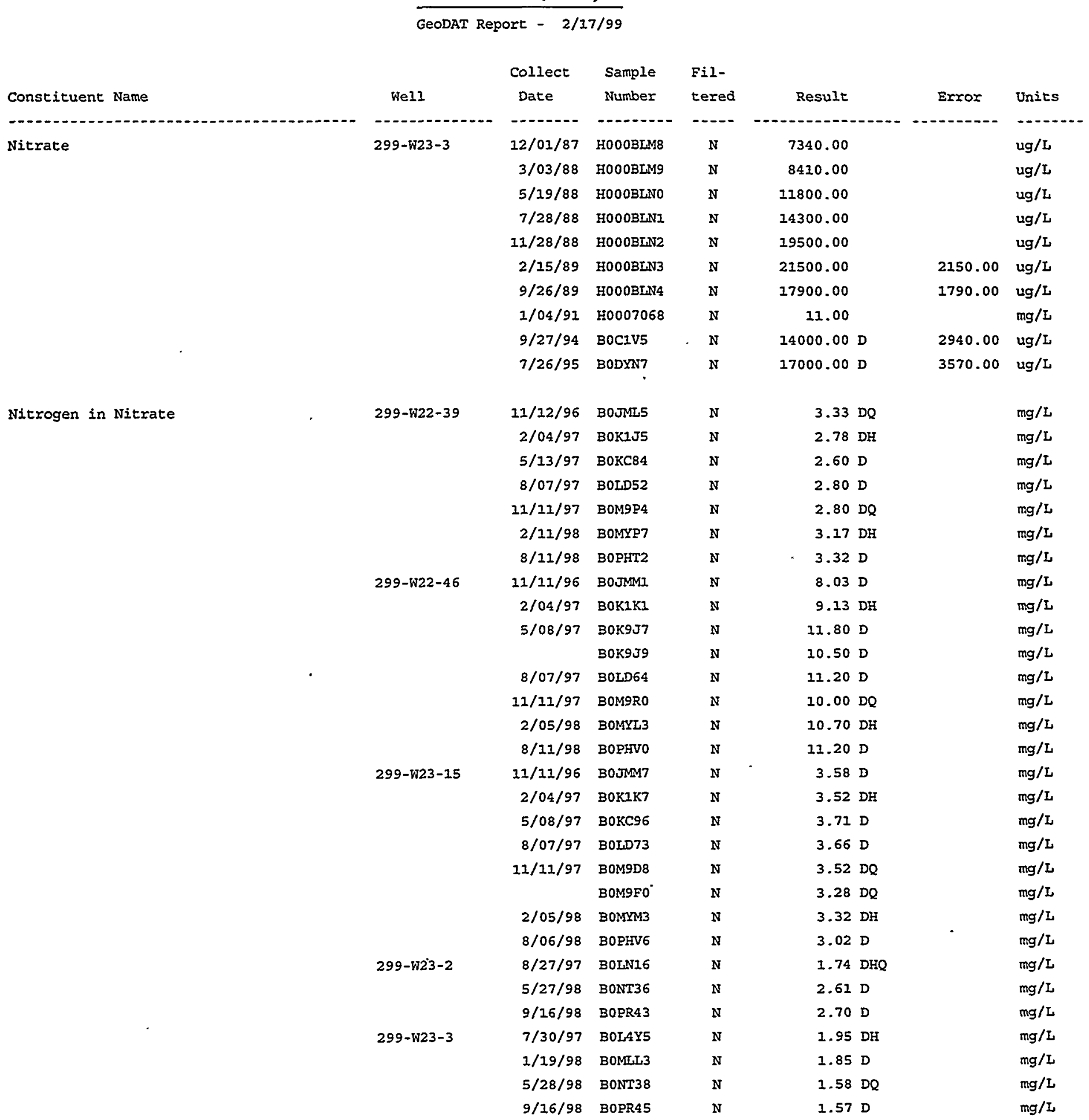


Data Table 9. This table provides data in reference to comment 124.

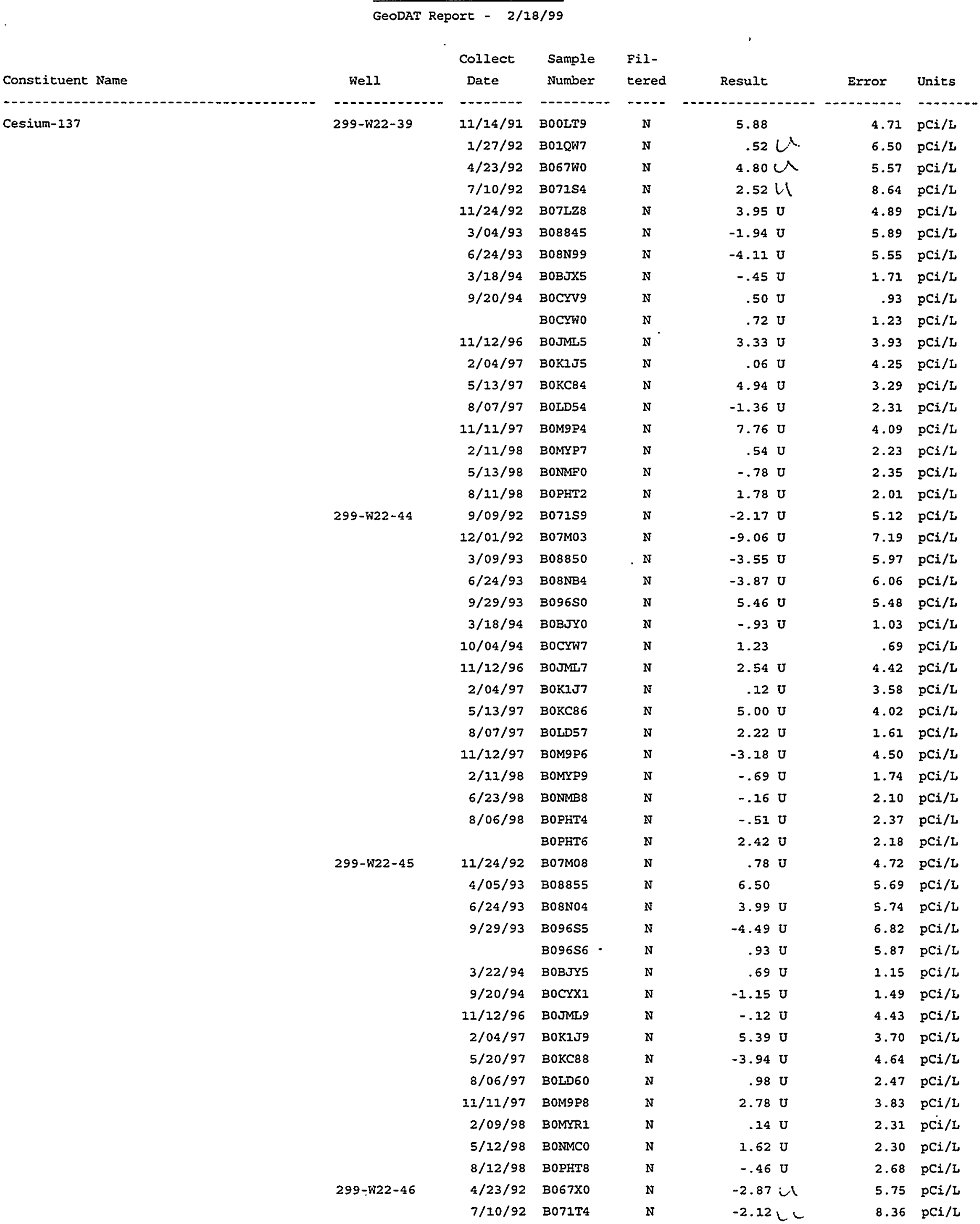


Data Table 9. (contd)

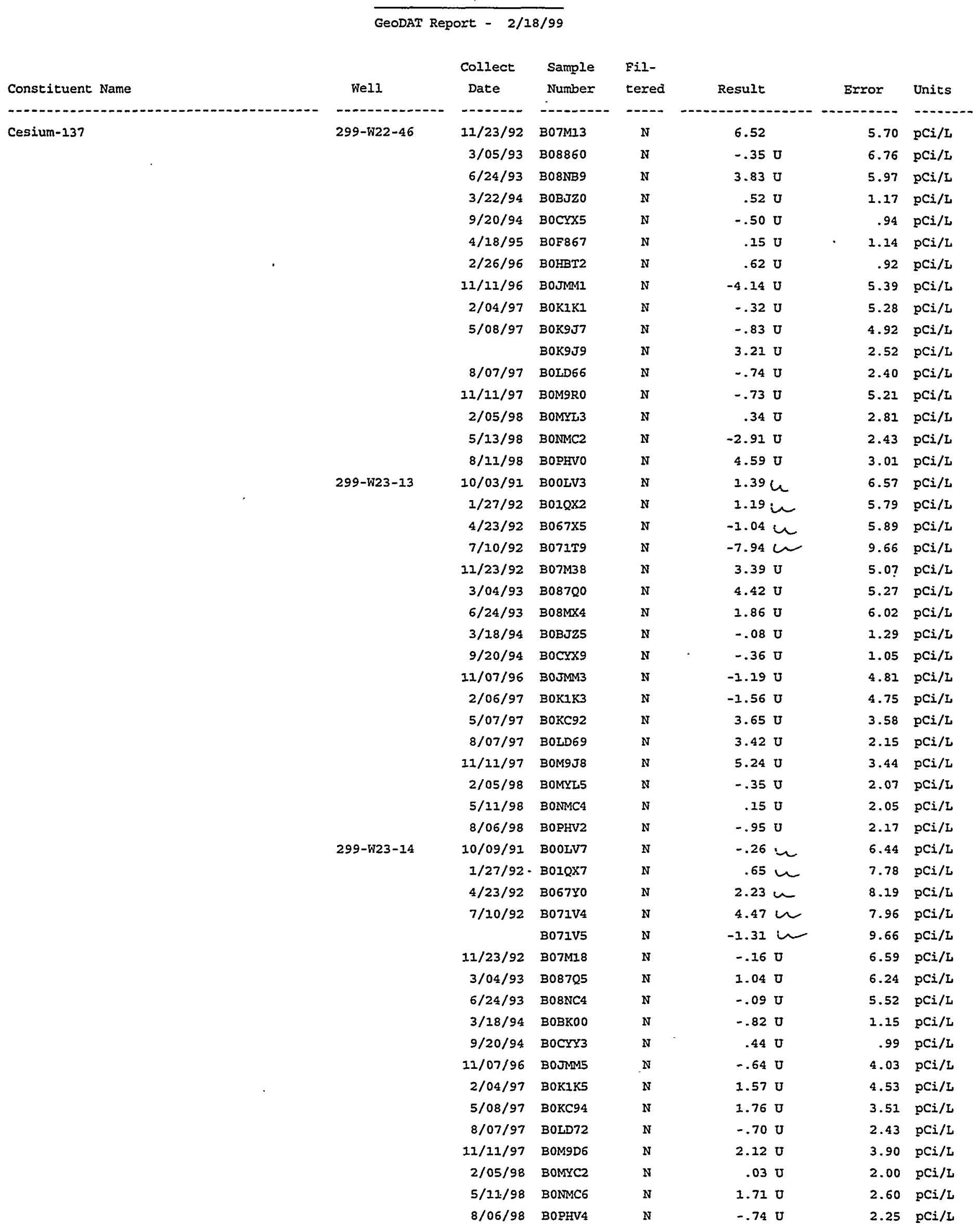


Data Table 9. (contd)

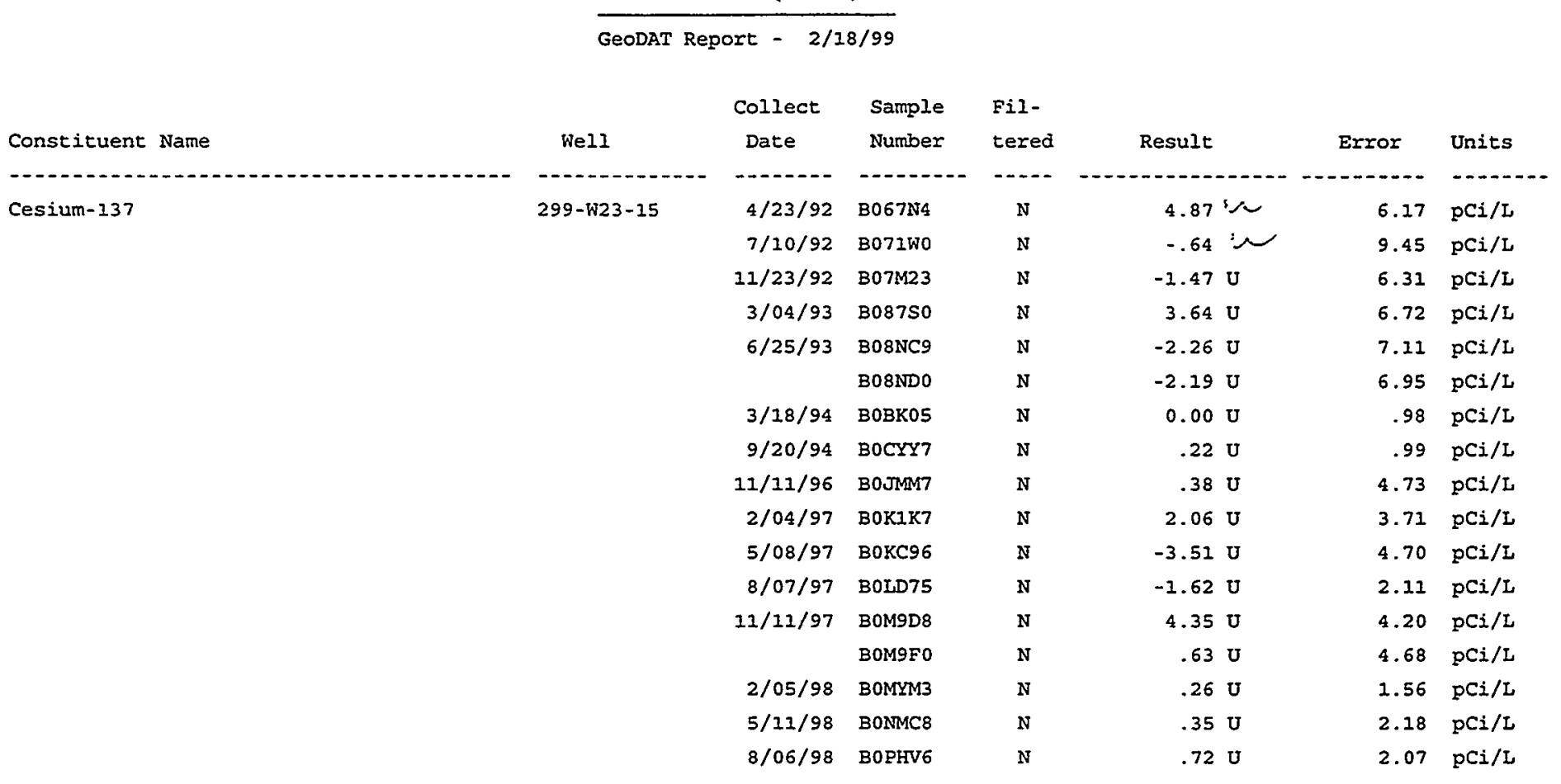


Data Table 10. This table provides data in reference to comment 125.

\begin{tabular}{|c|c|c|c|c|c|c|c|}
\hline & & & & & & & \\
\hline & GeODAT ReI & ort $-2 / 1$ & $8 / 99$ & & & & \\
\hline Constituent Name & Well & $\begin{array}{l}\text { Collect } \\
\text { Date }\end{array}$ & $\begin{array}{l}\text { Sample } \\
\text { Number }\end{array}$ & $\begin{array}{l}\text { Fil- } \\
\text { tered }\end{array}$ & Result & Error & Units \\
\hline 1 & 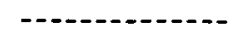 & $\cdots-\cdots--$ & $\cdots+\cdots$ & $-\cdots-$ & 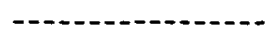 & $\cdots+\cdots$ & $-\ldots$. \\
\hline Cesium-137 & $299-$ W23-1 & $3 / 12 / 86$ & H000BJQ6 & $\mathbf{N}$ & $2.88 \mathrm{U}$ & 5.03 & $\mathrm{pCi} / \mathrm{L}$ \\
\hline & & $6 / 27 / 86$ & H0OOBJQ7 & $\mathrm{N}$ & 3.000 & 4.90 & $\mathrm{pCi} / \mathrm{L}$ \\
\hline & & $7 / 25 / 86$ & H000ВJQ8 & $\mathbf{N}$ & $-6.54 U$ & 6.71 & $\mathrm{pCi} / \mathrm{L}$ \\
\hline & & $1 / 28 / 87$ & HOOOBJRI & $\mathrm{N}$ & $1.72 \mathrm{U}$ & 5.06 & $\mathrm{pCi} / \mathrm{L}$ \\
\hline & & $7 / 01 / 87$ & H0OOBJR6 & $\mathrm{N}$ & 5.000 & 5.75 & $\mathrm{pCi} / \mathrm{L}$ \\
\hline & & $9 / 22 / 87$ & HOOOBJR8 & $N$ & $-4.54 \mathrm{U}$ & 8.30 & $\mathrm{pCi} / \mathrm{L}$ \\
\hline & & $12 / 01 / 87$ & HOOOBJR9 & $\mathrm{N}$ & $3.08 \mathrm{U}$ & 5.40 & $\mathrm{pCi} / \mathrm{L}$ \\
\hline & & $3 / 01 / 88$ & HOOOBJSI & $\mathrm{N}$ & -1.600 & 4.81 & $\mathrm{pC} \dot{\mathrm{I}} / \mathrm{L}$ \\
\hline & & $5 / 19 / 88$ & HOOOBJS2 & $\mathrm{N}$ & $-1.48 \mathrm{U}$ & 4.47 & $\mathrm{pCi} / \mathrm{L}$ \\
\hline & & $7 / 28 / 88$ & HOOOBJS3 & $\mathbb{N}$ & $2.63 \mathrm{U}$ & 8.31 & $\mathrm{pCi} / \mathrm{L}$ \\
\hline & & $11 / 28 / 88$ & H000BJS5 & $\mathrm{N}$ & $.37 \mathrm{U}$ & 5.86 & $\mathrm{pCi} / \mathrm{L}$ \\
\hline & & $2 / 15 / 89$ & H000BJS6 & $\mathrm{N}$ & $-4.33 \mathrm{U}$ & 5.79 & $\mathrm{pC} i / \mathrm{L}$ \\
\hline & & $9 / 26 / 89$ & но00ВJS7 & $\mathrm{N}$ & 8.27 & 6.47 & $\mathrm{pCi} / \mathrm{L}$ \\
\hline & & $3 / 11 / 96$ & BOHN 40 & $\mathbb{N}$ & 2.02 & 1.00 & $\mathrm{pCi} / \mathrm{L}$ \\
\hline & & $8 / 28 / 97$ & BOLN12 & $\mathrm{N}$ & $-.17 \mathrm{U}$ & 2.09 & $\mathrm{pCi} / \mathrm{L}$ \\
\hline & & & BOLN14 & $\mathbf{N}$ & .700 & 2.43 & $\mathrm{pCi} / \mathrm{L}$ \\
\hline & & $1 / 21 / 98$ & B0МX93 & N & $1.82 \mathrm{U}$ & 2.40 & $\mathrm{pCi} / \mathrm{I}$ \\
\hline & & $5 / 27 / 98$ & BONM26 & $\mathbf{N}$ & -1.99 U & 2.59 & $\mathrm{pCi} / \mathrm{L}$ \\
\hline & & $9 / 16 / 98$ & BOPR41 & $\mathrm{N}$ & $-.00 \mathrm{v}$ & 2.44 & $\mathrm{pCi} / \mathrm{I}$ \\
\hline
\end{tabular}




\section{Data Table 10. (contd)}

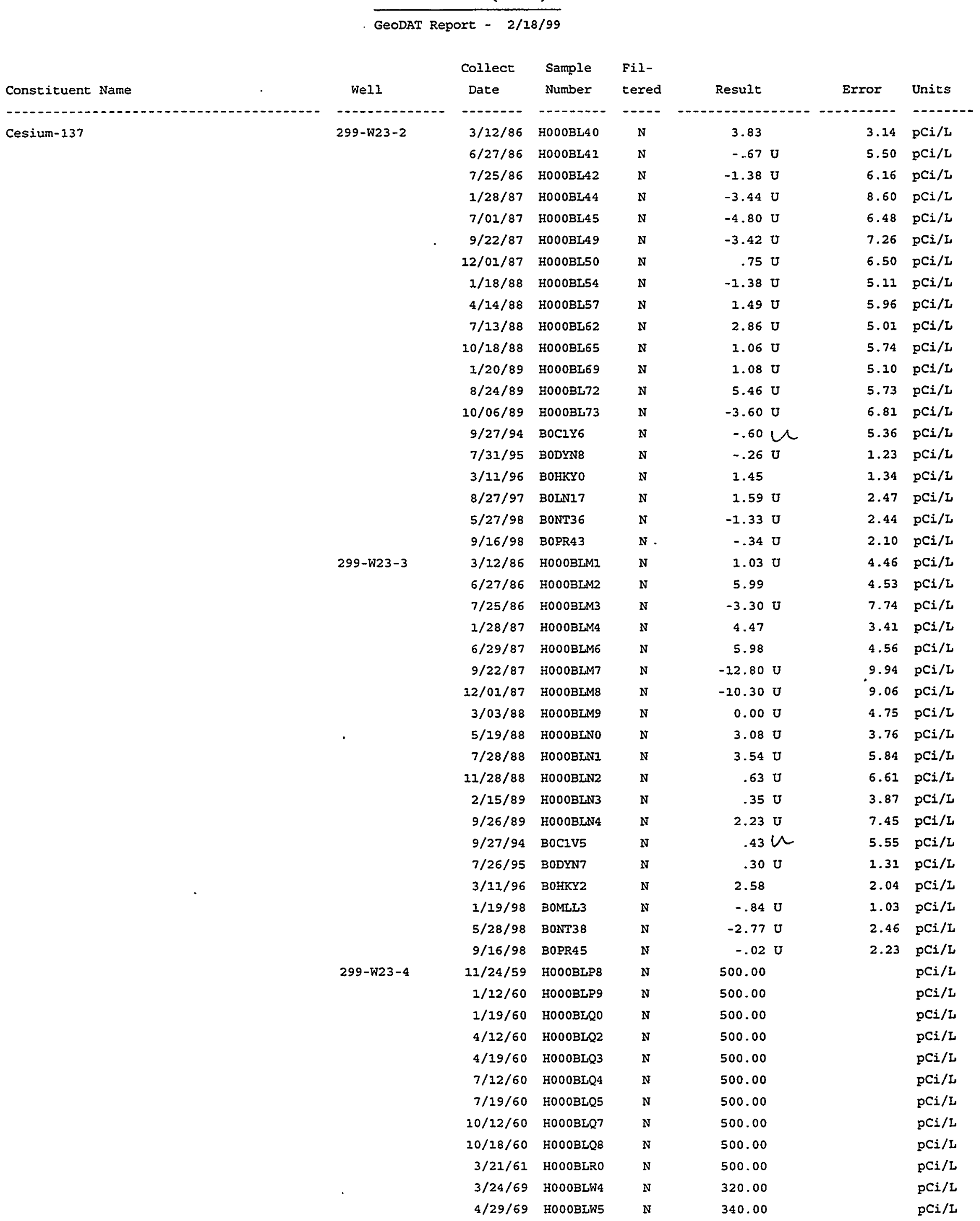


Data Table 10. (contd)

GeoDAT Report - 2/18/99

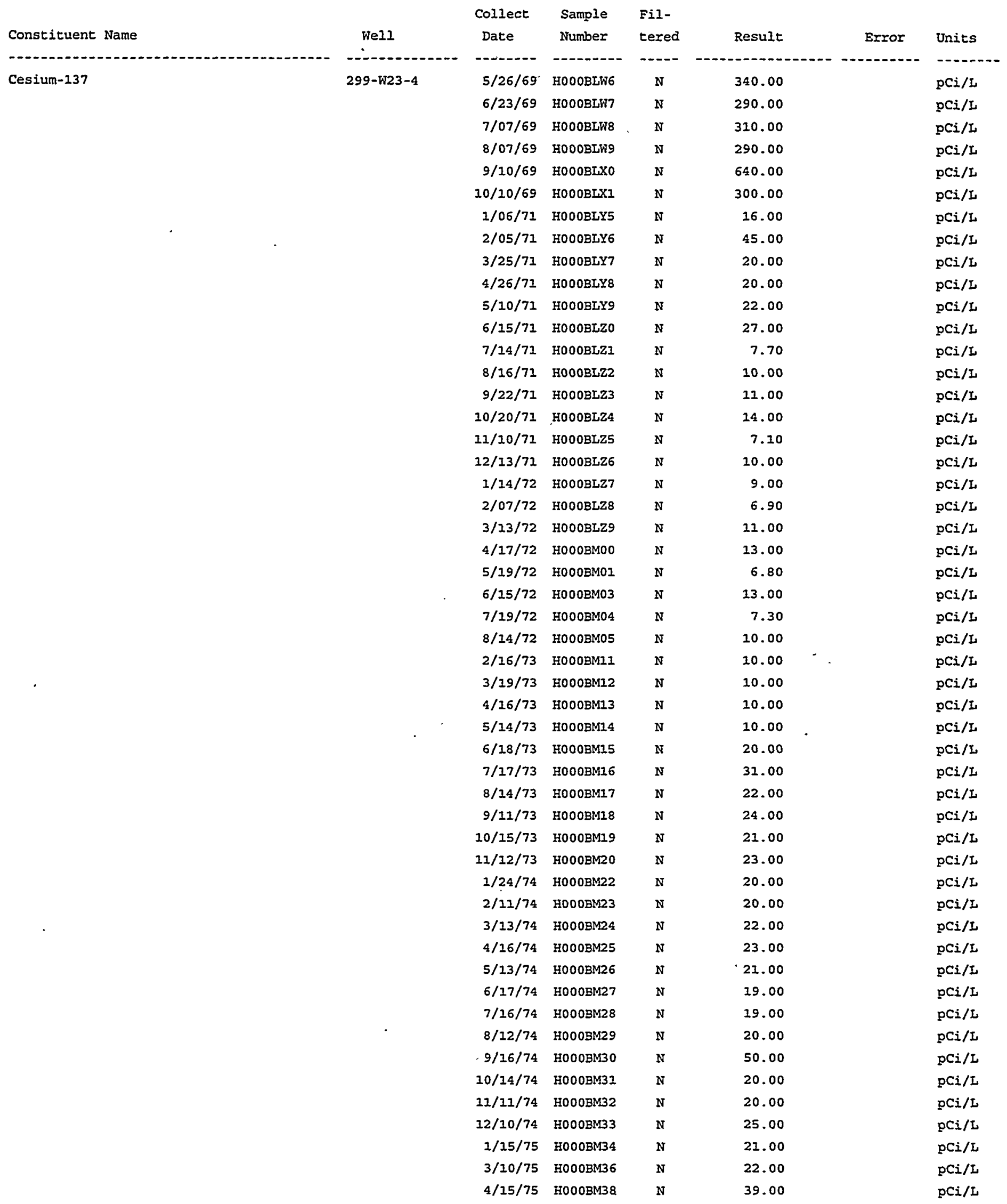




\section{Data Table 10. (contd)}

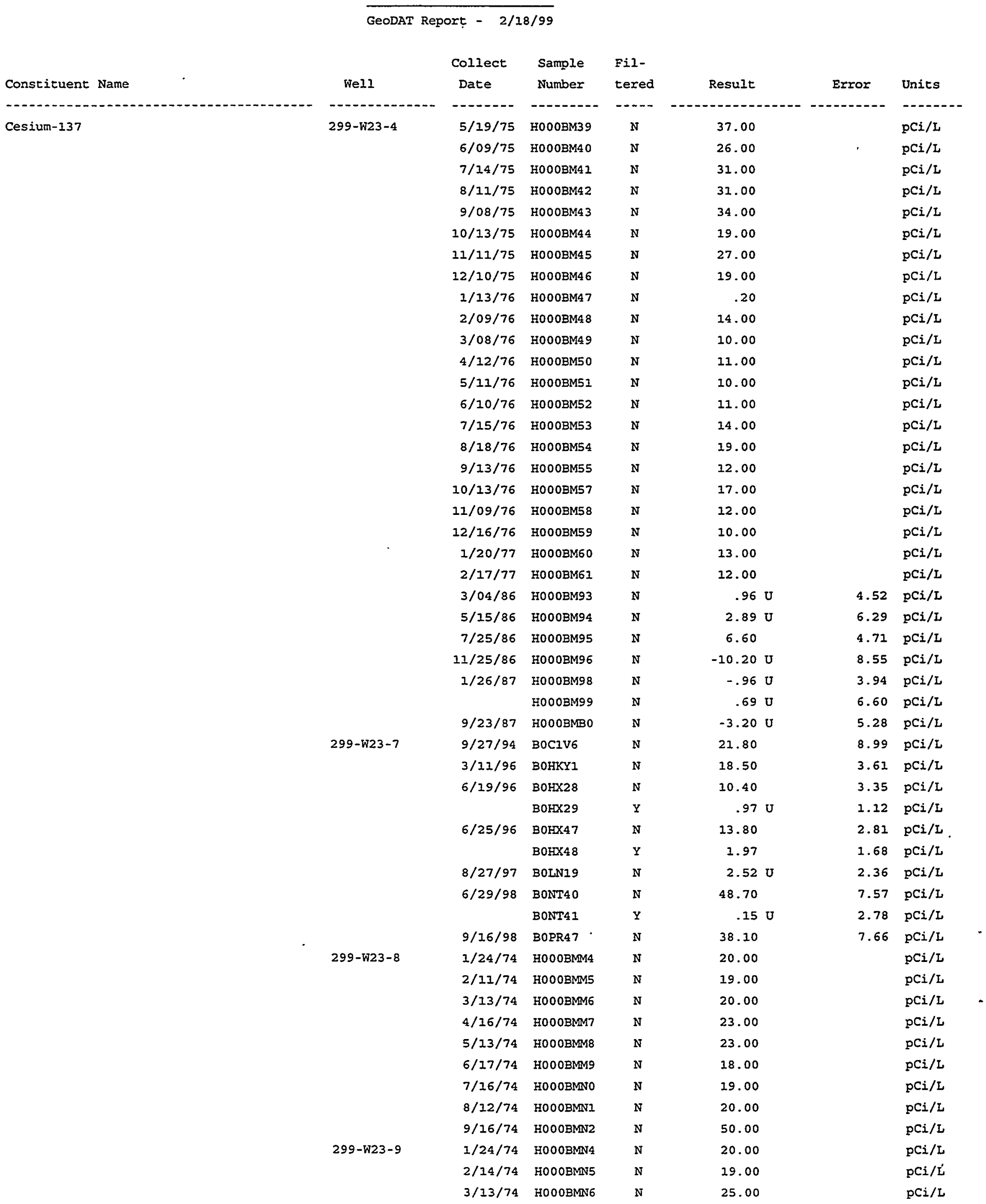


Data Table 10. (contd)

GeODAT Report - 2/18/99

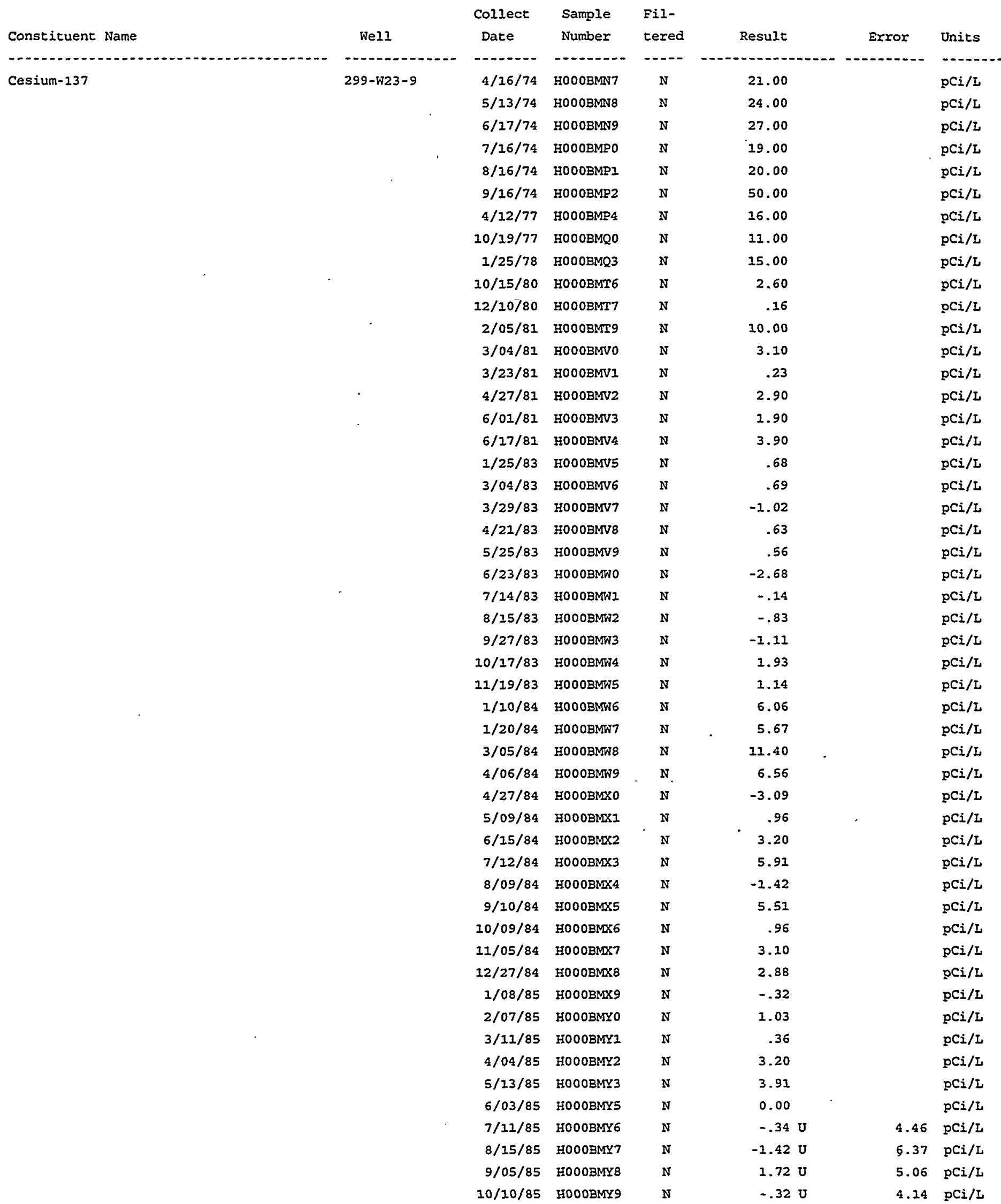


Data Table 10. (contd)

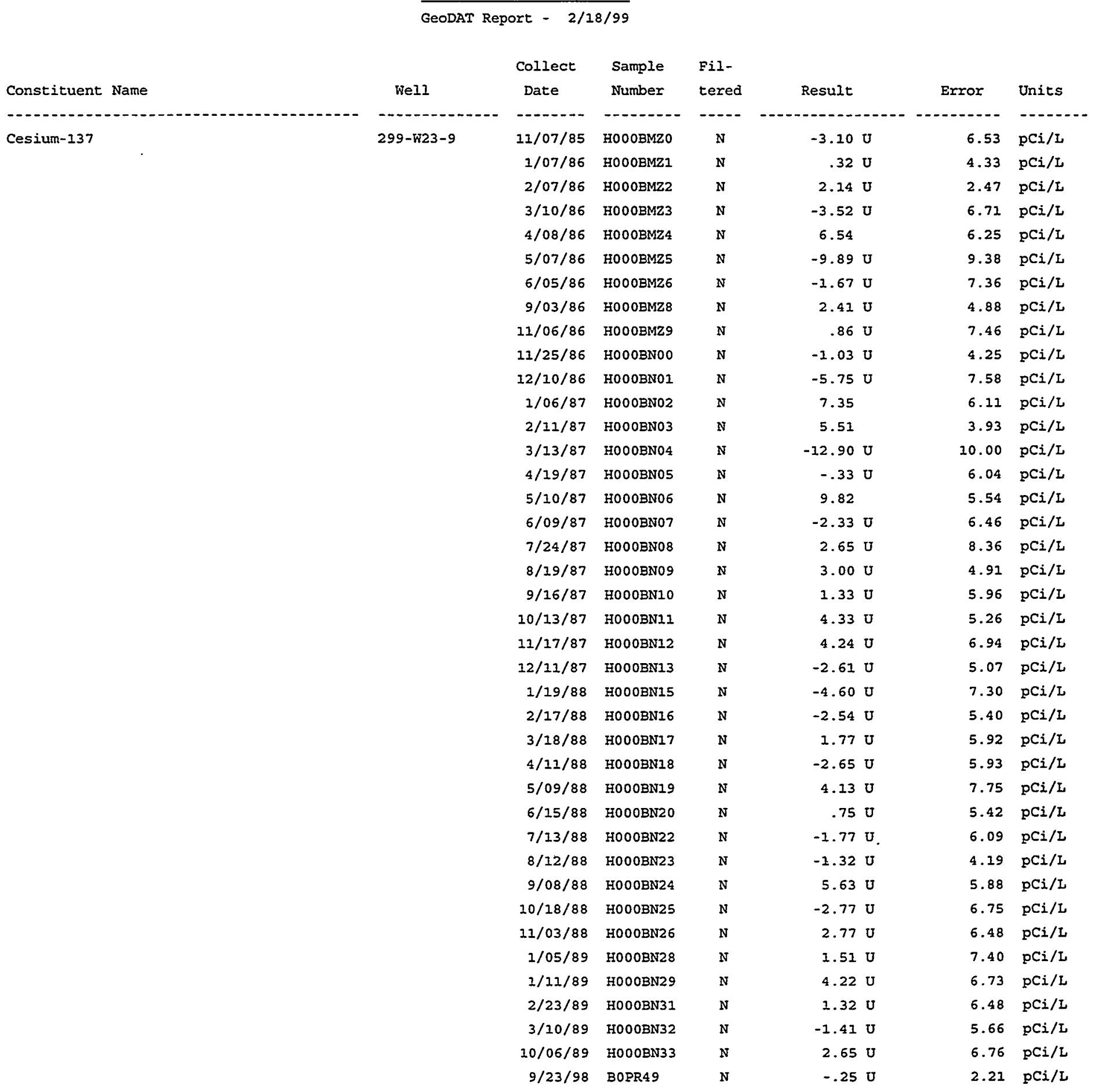


Data Table 11. This table provides data in reference to comment 140.

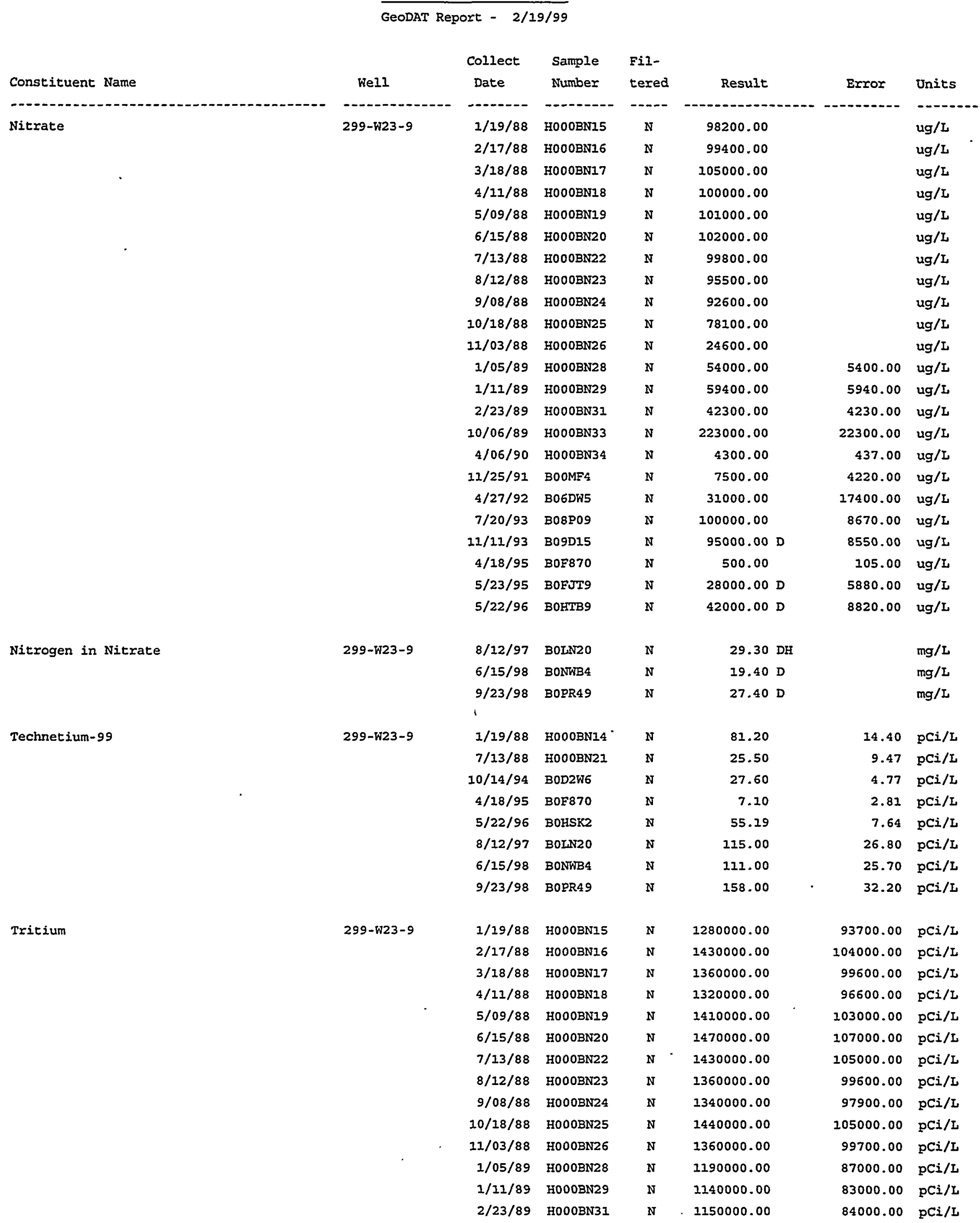


Data Table 11. (contd)

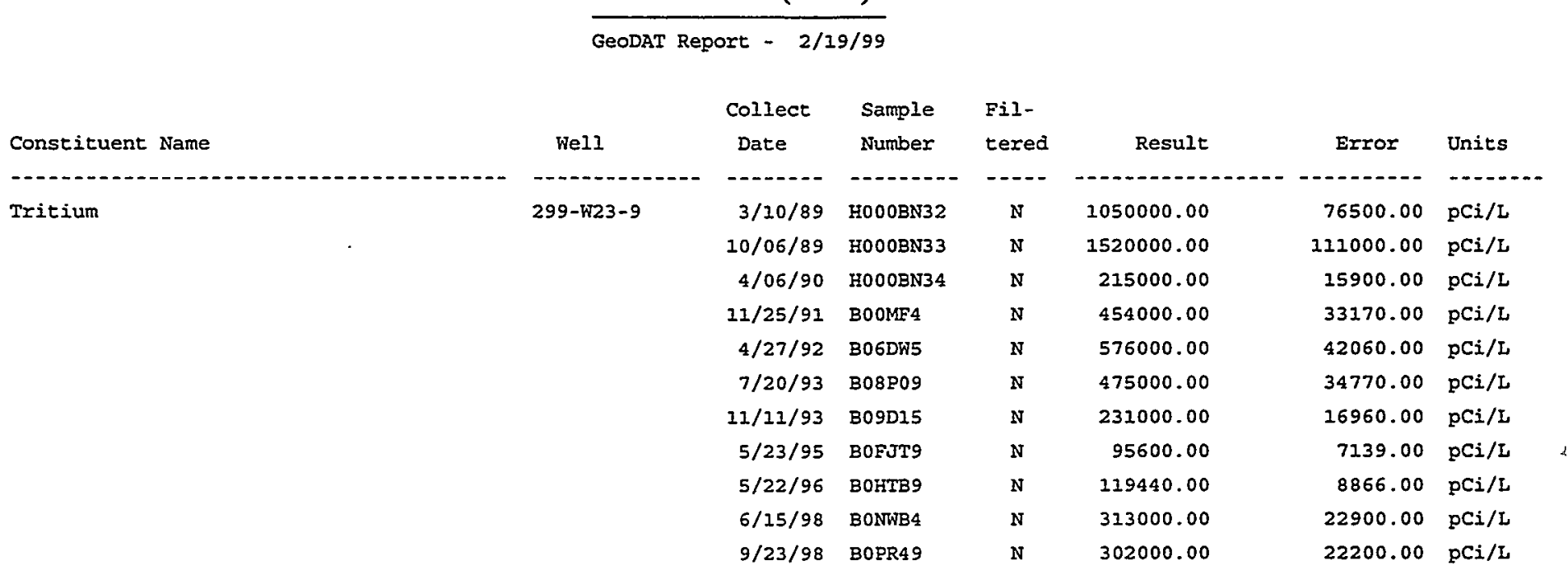




\section{References}

40 CFR 265, Code of Federal Regulations. Interim Status Standards for Owners and Operations of Hazardous Waste Treatment, Storage, and Disposal Facilities.

Ames, L. L. and R. J. Serne. 1991. Compilation of Data to Estimate Groundwater Migration Potential for Constituents in Active Liquid Discharges at the Hanford Site, PNL-7660, Pacific Northwest Laboratory, Richland, Washington.

Atomic Energy Act of 1954, as amended, 68 Stat. 919, 42 USC 2011 et seq.

BHI 1998. Hanford Site Atlas, BHI-01119, Rev. 1, May 1998, Bechtel Hanford, Inc., Richland, Washington.

Caggiano, J. A. 1996. Assessment Groundwater Monitoring Plan for Single-Shell Tank Waste Management Area S-SX. WHC-SD-EN-AP-191, Rev. 0, Westinghouse Hanford Company, Richland, Washington.

DOE 1996. Vadose Zone Characterization Project at the Hanford Tank Farms: SX Tank Farm Report. DOE/1D/12584-268, prepared by the U.S. Department of Energy, Albuquerque Operations Office, Grand Junction Projects Office for Richland Operations Office, Richland, Washington.

DOE 1998. Hanford Tank Farms Vadose Zone S Tank Farm Report.GJO-97-31-TAR, prepared by the U.S. Department of Energy, Albuquerque Operations Office, Grand Junction Projects Office for Richland Operations Office, Richland, Washington.

HNF-2855. 1998. Findings of the Extension of Borehole 41-09-39, 241-SX Tank Farm. D. A. Myers, D. J. Moak, D. L. Parker, G. W. Gee, R. J. Serne, V. G. Johnson, and G. V. Last, Lockheed Martin Hanford Corporation, Richland, Washington.

PNNL-12114. 1999. RCRA Assessment Plan for Single-Shell Tank Waste Management Area S-SX at the Hanford Site. V. G. Johnson and C. J. Chou, Pacific Northwest National Laboratory, Richland, Washington.

PNNL-11463. 1997. A Comprehensive Analysis of Contaminant Transport in the Vadose Zone Beneath Tank SX-109. A. L. Ward, G. W. Gee, and M. D. White, Pacific Northwest National Laboratory, Richland, Washington.

PNNL-11495. 1997. Chemical Information on Tank Supernatants, Cs Adsorption from Tank Liquids Onto Hanford Sediments, and Field Observations of Cs Migration from Past Tank Leaks. R. J. Serne, J. M. Zachara, and D. S. Burke, Pacific Northwest National Laboratory, Richland, Washington. 
PNNL-11810. 1998. Results of Phase I Groundwater Quality Assessment for Single-Shell Tank Waste Management Areas S-SX at the Hanford Site. V. G. Johnson and C. J. Chou, Pacific Northwest National Laboratory, Richland, Washington.

PNNL-12086. 1998. Hanford Site Groundwater Monitoring for Fiscal Year 1998. M. J. Hartman (ed.), Pacific Northwest National Laboratory, Richland, Washington.

Raymond, J. E. and E. G. Shdo. 1966. Characterization of Subsurface Contamination in the SX Tank Farm. BNWL-CC-701. Battelle Northwest, Richland, Washington.

Serne, R. J., J. M. Zachara and D. S. Burke. 1997. Chemical Information on Tank Supernatants, Cs Adsorption from Tank Liquids onto Hanford Sediments, and Field Observations of Cs Migration from Past Tank Leaks. PNNL-1 1495, Pacific Northwest National Laboratory, Richland, Washington.

WAC 173-303-400, Washington Administrative Code. Interim Status Facility Standards. Olympia, Washington. 


\section{Distribution}

No. of

Copies

OFFSITE

C. Abraham

U.S. General Accounting Office

825 Jadwin Ave., MSIN \#A1-80

Richland, WA 99352

2 Confederated Tribes and Bands of the

Yakama Indian Nation

Environmental Restoration Waste

Management Program

P.O. Box 151

Toppenish, WA 98948

ATTN: W. Riggsbee

R. Jim

2 Confederated Tribes of the Umatilla Indian

Reservation

P.O. Box 638

Pendleton, OR 97801

ATTN: B. Burke

T. Gilmore

T. French

Savannah River Site

Aiken, SC 29802

2 Nez Perce Tribe

Nez Perce Tribal Department of

Environmental Restoration and Waste

Management

P.O. Box 365

Lapwai, ID 83540

ATTN: D. Powaukee

S. Sobczyk
No. of

Copies

R. Patt

Oregon Water Resources

Water Resources Department

555 13th Street Northeast

Salem, OR 97301

G. Pollet

Heart of America Northwest

Heart of American Northwest, Suite 208

Seattle, WA 98101

P. Rogers

Jacobs Engineering Group, Inc.

3250 W. Clearwater Ave.

Kennewick, WA 99336

S. Van Verst

Washington State Department of Health

Airdustrial Park, Bldg. 5

Olympia, WA 98504

\section{ONSITE}

\section{DOE Richland Operations Office}

C. E. Clark

A5-15

M. J. Furman (7)

H0-12

J. B. Hall

A5-15

R. D. Hildebrand

H0-12

R. A. Holten

H0-12

R. W. Lober

S7-51

E. M. Mattlin

A5-15

J. K. McClusky

S7-54

J. A. Poppiti

G3-08

E. J. Rasmussen

A5-58

K. M. Thompson

$\mathrm{H} 0-12$

Public Reading Room
$\mathrm{H} 2-53$

Distr.l 
PNNL-11810 ADD. 1

No. of

Copies

2 Bechtel Hanford, Inc.

B. H. Ford

G. Hinkel

2 Fluor Daniel Hanford, Inc.
E. A. Fredenburg
F. A. Ruck
H6-12
H6-23

Fluor Daniel Northwest, Inc.

F. M. Mann

B4-43

7 Lockheed Martin Hanford Corporation
R. J. Brown
C. B. Bryan
B. G. Erlandson
K. R. Fecht
A. J. Knepp
D. A. Myers
R. D. Wojtasek

T4-08

T4-07

R1-51

$\mathrm{HO}-02$

$\mathrm{HO}-22$

G3-21

G3-21

\section{MACTEC-ERS}

J. F. Bertsch

B1-42

R. G. McCain

B1-42

\section{U.S. Environmental Protection Agency}

D. R. Sherwood

B5-01

5 Washington State Department of Ecology

S. L. Dahl

B5-18

D. N. Goswami

B5-18

A. D. Huckaby

B5-18

S. Leja

B5-18

S. McKinney (Olympia)
No. of

Copies

2 Waste Management Federal Services, Inc.

J. C. Sonnichsen

H6-26

M. I. Wood

H6-06

Waste Management Northwest

M. G. Gardner

H1-11

59 Pacific Northwest National Laboratory

K. J. Cantrell

K6-81

C. J. Chou (5)

K6-81

J. L. Devary

K6-96

P. E. Dresel

K6-96

R. M. Ecker

J. C. Evans, Jr.

K6-91

G. W. Gee

K6-96

M. J. Hartman

K9-33

F. N. Hodges

K6-96

G. R. Holdren

K6-81

K6-81

D. G. Horton

K6-81

V. G. Johnson (20)

K6-96

S. P. Luttrell (5)

K6-96

S. V. Mattigod

K6-81

R. B. Mercer

K6-96

L. F. Morasch

K6-86

S. M. Narbutovskih $\quad$ K6-81

T. L. Page

K9-18

S. P. Reidel

K6-81

R. Schalla

K6-96

R. J. Serne

K6-81

R. M. Smith

K6-96

F. A. Spane

K6-96

P. D. Thorne

K9-33

B. A. Williams

K6-81

J. H. Zachara

K8-96

Information Release Office (7)

K1-06 